\title{
Polarity in Contemporary International Politics: A Uni-interpolar Order?
}

by

\section{OLUWASEUN EMMANUEL TELLA (212561272)}

Supervisor:

Dr. Khondlo Mtshali

Submitted in fulfilment of the academic requirements for the degree of Doctor of Philosophy (Political Science) in the Graduate Programme in the College of Humanities,

School of Social Sciences, of the University of KwaZulu-Natal, Pietermaritzburg, South Africa.

November 2014 


\section{Declaration}

I, Oluwaseun Emmanuel Tella (Student Number 212561272), declare that:

1. The research reported in this thesis, except where otherwise indicated, is my original work.

2. This thesis has not been submitted for any degree or examination at any other university.

3. This thesis does not contain other persons' data, pictures, graphs or other information, unless specifically acknowledged as being sourced from such persons.

4. This thesis does not contain other persons' writing, unless specifically acknowledged as being sourced from other researchers. Where other written sources have been quoted, then:

a. Their words have been re-written but the general information attributed to them has been referenced;

b. Where their exact words have been used, then their writing has been placed in italics and inside quotation marks, and referenced.

5. This thesis does not contain text, graphics or tables copied and pasted from the Internet, unless specifically acknowledged, and the source being detailed in the thesis and in the References sections.

\section{Oluwaseun Tella (Student)}

Signature

Date

Khondlo Mtshali (Supervisor)

Signature

Date 


\begin{abstract}
Reference to the structural impact of the emergence and resurgence of new and old great powers in international politics is common in the literature on international politics. This study has attempted to explore this subject matter by investigating the hard and soft power currencies of the great powers. The study relied on both primary and secondary sources of data to solicit dependable data on the subject matter. The researcher relied on content and historical analysis to for meaningful assessment of the research themes. The study is explored through the lenses of the balance of power and multilateralism. The study found that the emerging powers, most especially the BRIC countries (in particular China) are making conscious attempts to invest both in their soft and hard power resources to narrow the gap between them and the United States in terms of power resources and influence. The study also found out that the model appropriate to describe today's polarity must take into cognisance the major features of contemporary international politics which include the United States' relative decline, the emergence and resurgence of new and old players and the comprehensive interdependence that characterises international politics in the $21^{\text {st }}$ century. Thus, the study concludes by proffering that uniinterpolarity (a hybrid of Huntington's uni-multipolarity and Grevi's interpolarity) is the model that adequately captures the major features of contemporary international politics.
\end{abstract}

Key words: polarity, soft power, balance of power, interdependence 


\section{ACKNOWLEDGEMENTS}

Writing is by its nature a solitary activity; responding to the polarity in contemporary international system was by its nature a social undertaking. Thus, even in the deepest solitude, I depended on the support and input of many others. And while the faults and omissions are mine alone, this thesis could not have been written without my supervisors and colleagues on whose support I relied.

I must especially thank my supervisor, Dr. Khondlo Mtshali who gave me ideas, criticism and new insights. Without the tireless labour and support of Dr. Mtshali, it is doubtful this thesis would have been completed. My appreciation also goes to my proofreader, Kim Ward, whose fingerprints appear on almost all the pages of this dissertation.

I owe a profound debt of gratitude to my aunt, Mrs Karimot Faluade and her entire family members for providing me with the necessary support during my sojourn in this country (South Africa). Fortunately, I benefitted from my association with wide range of friends and colleagues such as Adeoye Akinola, Bola Eniola, Olusola Ogunnubi, Hakeen Onapajo, Mbali Gwacela, Ridemptor Rwenbagira and Tony Oyowe to whom I would like to express my appreciation.

Finally, I thank my family - my father, mother, brother and sister for providing me with invaluable moral support. Writing this thesis was expectedly a protracted and sometimes painful process. In order to persevere, it helps immensely to have strong support at home as well as in the intellectual environment. I was fortunate to have both. 


\section{DEDICATION}

This thesis is dedicated to the almighty God,

the perfect and omnipotent and omniscient originator and ruler of the universe. 


\section{Table of Contents}

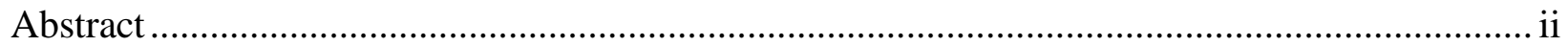

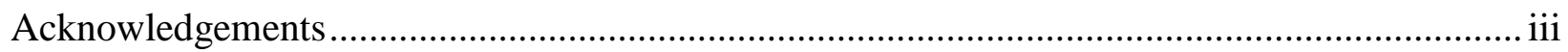

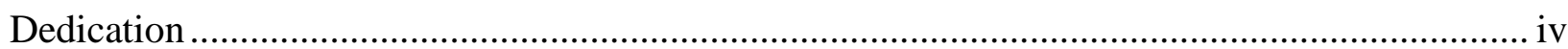

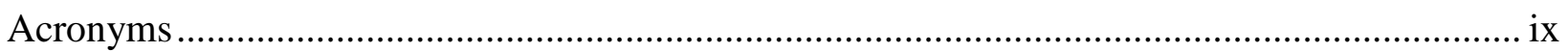

CHAPTER ONE Introduction............................................................................................... 1

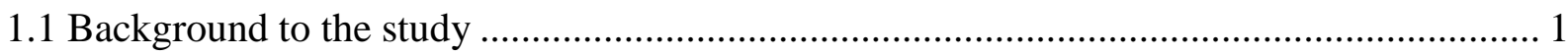

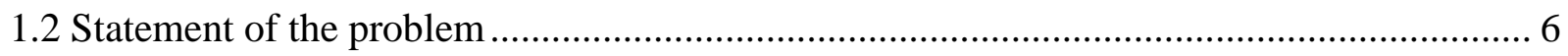

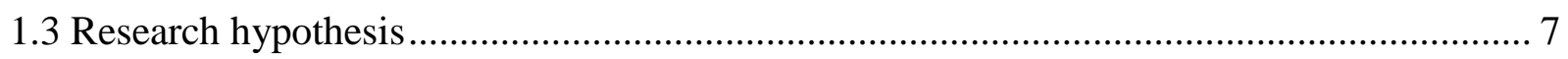

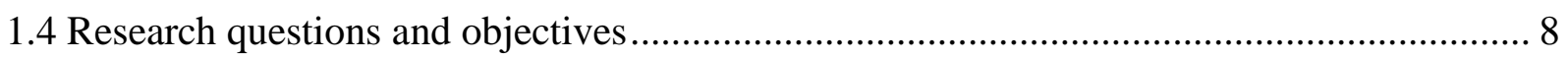

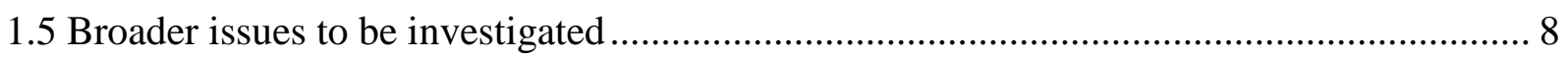

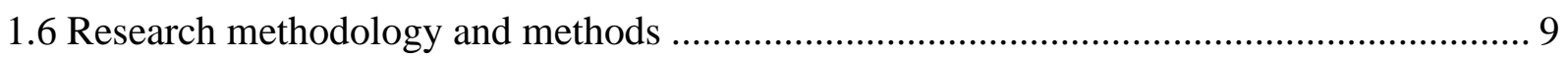

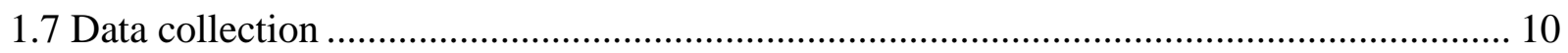

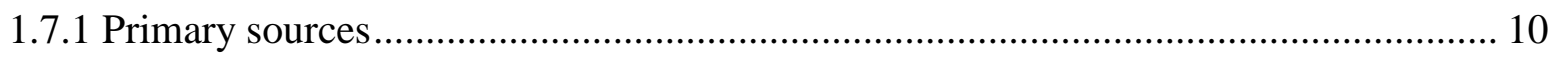

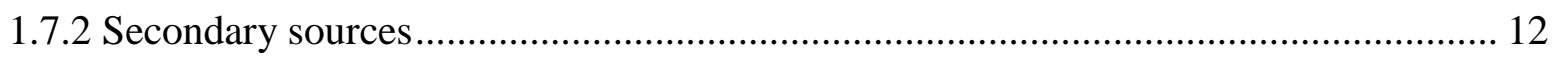

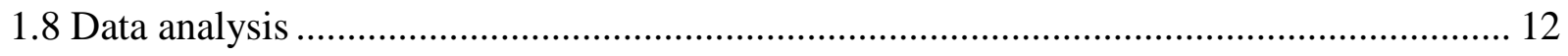

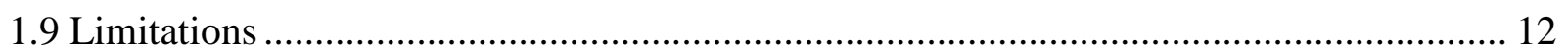

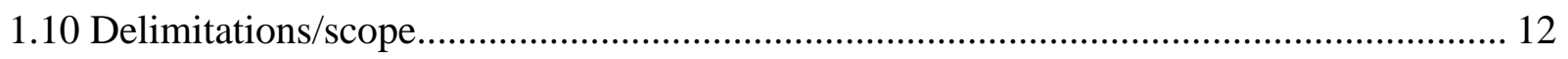

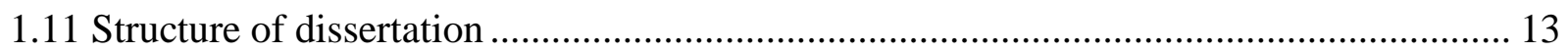

CHAPTER TWO A Review of Related Literature.............................................................. 16

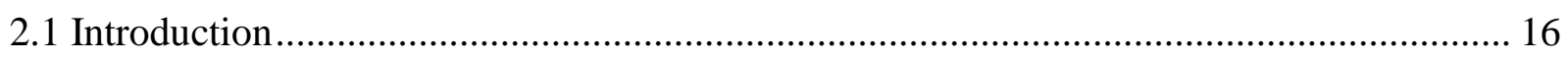

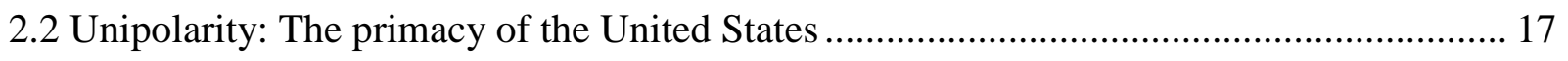

2.3 Multipolarity: The rise of emerging powers …..................................................... 25

2.4 Alternative models: Uni-multipolarity, nonpolarity and interpolarity ............................ 33

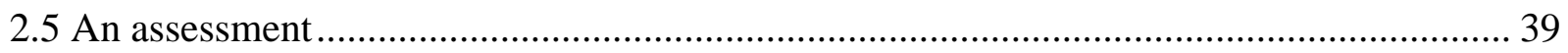

2.7 The United States and China's soft power............................................................... 45

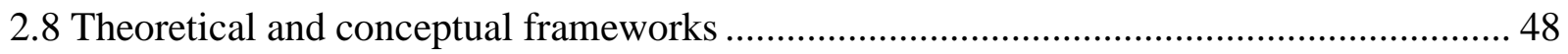

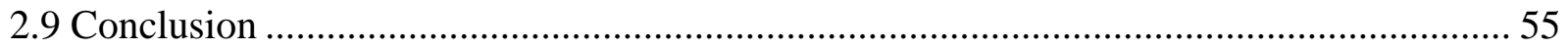

CHAPTER THREE The Twentieth Century World Order ................................................. 58

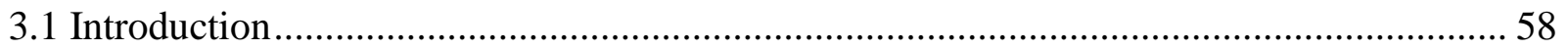




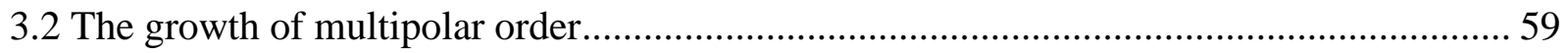

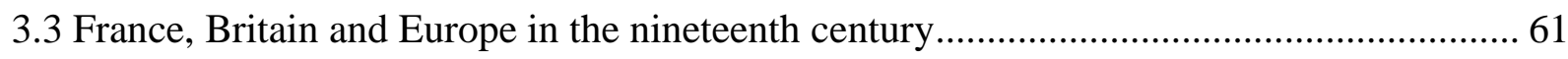

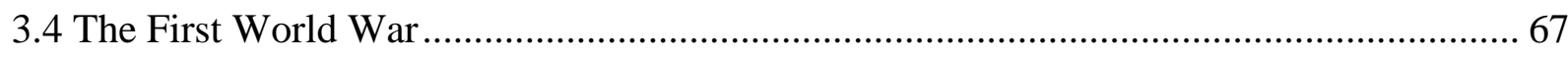

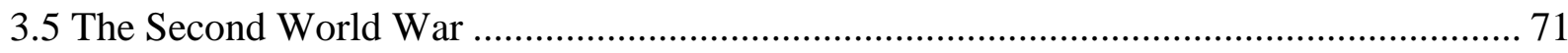

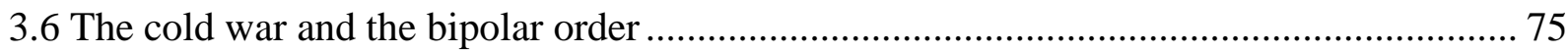

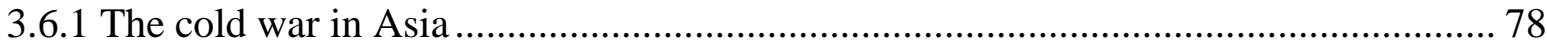

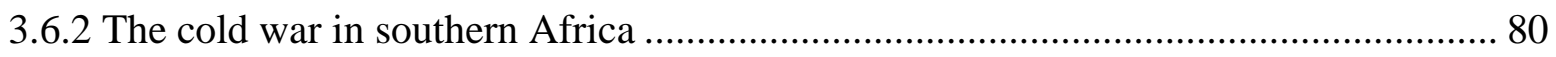

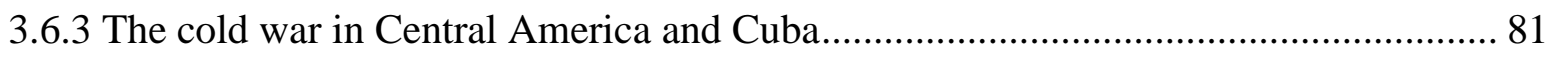

3.6.4 The end of the cold war and the unipolar order ...................................................... 85

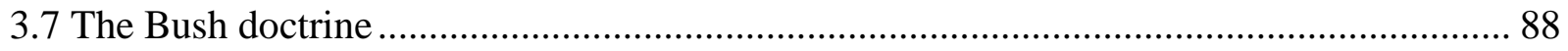

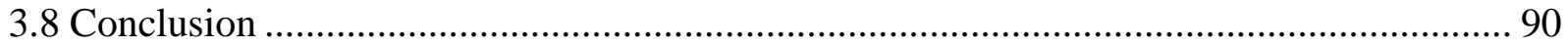

CHAPTER FOUR United States: Stable or Vanishing Hegemony........................................... 91

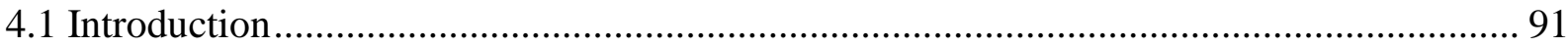

4.2 The United States hard power profiles......................................................................... 92

4.3 United States' soft power profiles.................................................................................. 97

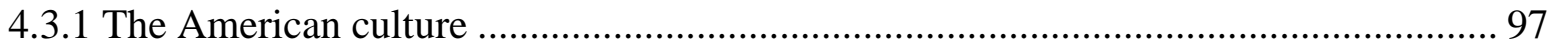

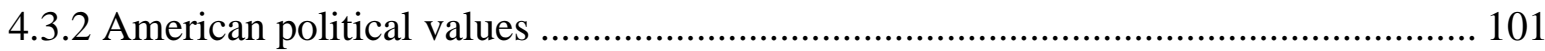

4.3.3 United States foreign policies ............................................................................... 105

4.3.4 America's soft power in Africa.......................................................................... 108

4.3.5 American foreign policy and political values in Africa.............................................. 110

4.3.6 American cultural exports in Africa ……………............................................... 120

4.3.7 United States soft power in the Middle East.............................................................. 122

4.3.8 American political values .................................................................................. 124

4.3.9 American foreign policies in the Middle East ........................................................ 126

4.4 Is the United States in decline? ............................................................................. 130

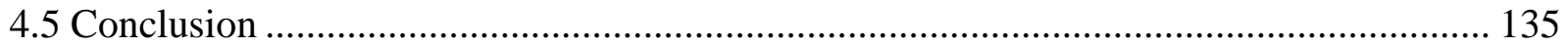

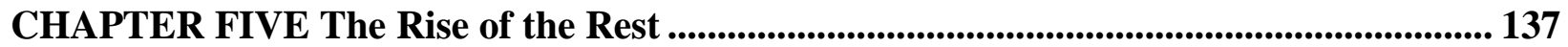

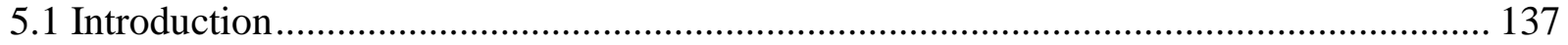

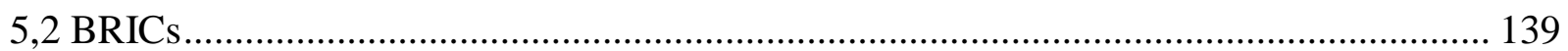

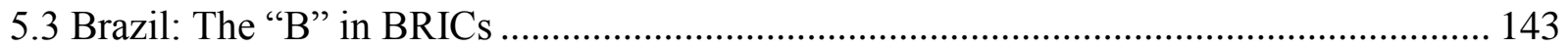

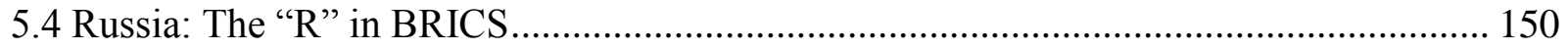

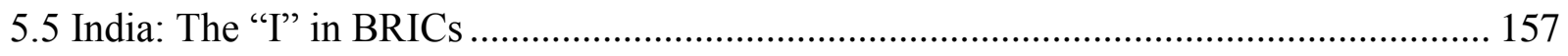




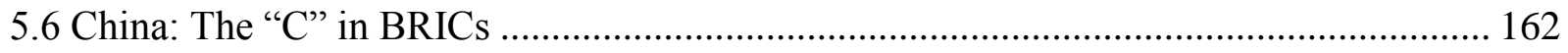

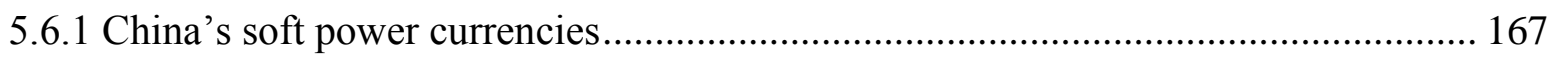

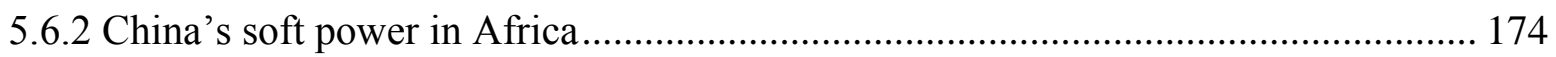

5.6.3 China's soft power in the Middle East..................................................................... 182

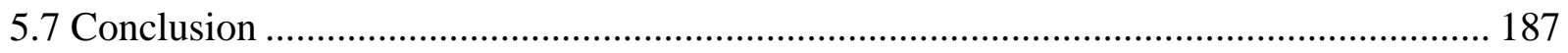

CHAPTER SIX A Uni-interpolar Order? ......................................................................... 189

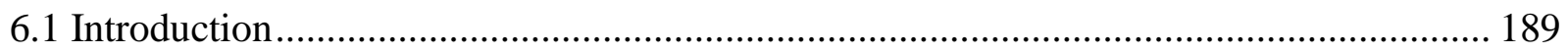

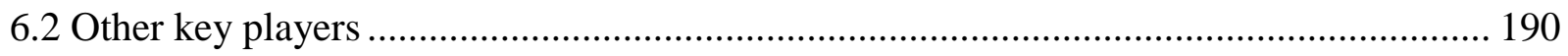

6.2.1 The European Union ..................................................................................... 190

6.2.2 Beyond BRIC: Other emerging states.............................................................. 193

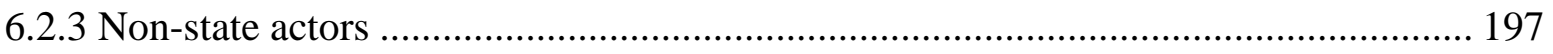

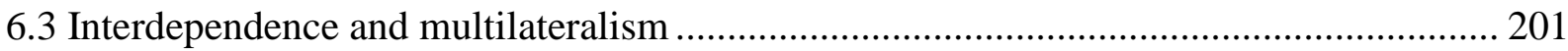

6.4 The American advantage over the other great powers...................................................... 205

6.5 A uni-interpolar world?............................................................................................. 210

CHAPTER SEVEN Summary and Conclusion .............................................................................. 215

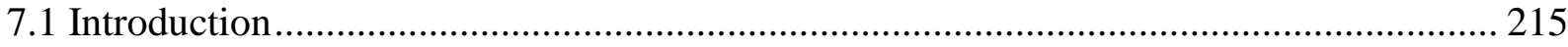

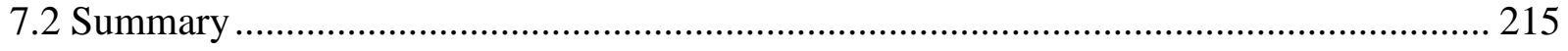

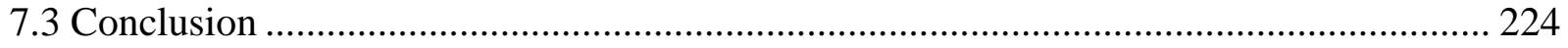

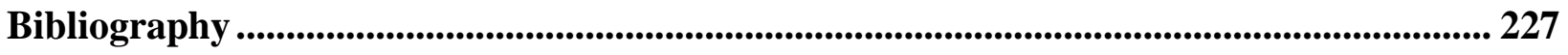




\section{List of Tables}

Table 3.1: Size of armies (people)

Table 3.2: British wartime expenditure and revenue (pounds) 59

Table 3.3: Britain's share of world manufacturing production, 1800-1980 62

Table 3.4: Total GNP and per capita GNP of the powers in $1950 \quad 72$

Table 3.5: Defence Expenditures of some of the great powers 73

Table 4.1: Introversion and extroversion patterns of cycles 87

Table 4.2: The world's ten largest economies in $2012 \quad 90$

Table 4.3: The 15 countries with the highest military expenditure in 201292

Table 4.4: Top 10 most popular musicians on twitter in 2014

Table 4.5: Top five places of origin of international students in the US 96

Table 4.6: Electoral democracies, 1989-2012 98

$\begin{array}{ll}\text { Table 4.7: US favourability } & 101\end{array}$

Table 4.8: Obama positive ratings 102

Table 4.9: US favourability in Africa 104

Table 4.10: US support for Nigeria 113

Table 4.11: US support to fight HIV/AIDS in South Africa 114

Table 4.12: US favourability in the Middle East $\quad 118$

Table 5.1: Nuclear warheads of the great powers 146

Table 5.2: Gross Domestic Product per capita 161

$\begin{array}{ll}\text { Table 5.3: China’s favourability } & 168\end{array}$

Table 5.4: The top soft powers 169

Table 5.5: China's favourability in Africa 176

Table 5.6: China's favourability in the Middle East in $2013 \quad 181$ 


\section{Acronyms}

AfDB

AFRICOM US

AGOA

ASEAN

BBC

BRIC

BRICS

CENTCOM

CIA

CIS

$\mathrm{CNN}$

DOD

EU

EUCOM

FDI

FIEs

FIFA

FOCAC

GATT

GDP

GNP

GSP

IAEA

IBSA

IGO

IMF

ISIS

KFC

MCA
African Development Bank

Africa Command

African Growth and Opportunity Act

Association of South East Asian Nations

British Broadcasting Corporation

Brazil, Russia, India and China

Brazil, Russia, India, China, South Africa

US Central Command

Central Intelligence Agency

Common Wealth of Independent States

Cable Network News

US Department of Defense

European Union

US European Command

Foreign Direct Investment

Foreign Invested Enterprises

International Federation of Football Association

Forum on China-Africa Cooperation

General Agreement on Tariffs and Trade

Gross Domestic Product

Gross National Product

Generalised System of Preference

International Atomic Energy Agency

India, Brazil and South Africa

International Governmental Organisation

International Monetary Fund

Islamic State of Iraq and Syria

Kentucky Fried Chicken

Millennium Challenge Account 
MCC

MEPI

$\mathrm{MNC}$

MINT

MPLA

MTV

NATO

NIC

NGO

OPEC

PEPFAR

$\mathrm{R} \& \mathrm{D}$

SADC

SCO

UN

UNESCO

US

USAID

USSR

WTO
Millennium Challenge Corporation

Middle East Partnership Initiative

Multinational Corporation

Mexico, Indonesia, Nigeria and Turkey

Popular Movement for the Liberation of Angola

Music Television

North Atlantic Treaty Organisation

National Intelligence Council

Non Governmental Organization

Organization of the Petroleum Exporting Countries

President's Emergency Plan for AIDS Relief

Research and Development

Southern African Development Community

Shanghai Co-operation Organisation

United Nations

United Nations Educational, Scientific and Cultural Organisation

United States

United States Agency for International Development

Union of Soviet Socialist Republics

World Trade Organisation 


\section{CHAPTER ONE}

\section{Introduction}

\subsection{Background to the study}

It is common knowledge that the world is changing. What is debatable, however, is the direction of the shift (Grevi, 2009). After the demise of the Soviet Union, the bipolar order that had influenced power relations among states collapsed. Consequently, the United States emerged as the undisputed hegemon in the international system. Many scholars described the era as the beginning of a "unipolar moment" in international politics. Others argued that the United States had emerged as the sole surviving Super Power. The 1990s was characterised by the preponderance of the United States in global politics. It became so dominant that it enjoyed unchallenged global primacy (Wohlforth 1999; Walt 2009; Norrlof 2010). The "unipolar moment" symbolised the beginning of an epoch in which the United States enjoyed superiority in military and economic capabilities. This provided a platform for the United States to promote its global interests as it could act decisively in almost every strategic part of the world without a strong challenger. What appeared to be a subject of controversy was when the "unipolar moment" would be over. Scholars, particularly in the realist school of thought, argued that states' tendency to prevent the emergence of a hegemon or balance the overwhelming power of the dominant state, would trigger an end to the unipolar moment. They argued that the unipolar moment would be short-lived. In the words of Eldelman (2010, p. 1) "In the end those predictions failed to materialise and the United States retained, for the next decade and a half, a position of overwhelming primacy, flexibility and strategic advantage in the international arena".

However, there has been a dramatic change in the power configuration of international politics particularly after the September 2001 attacks on the United States. The United States still remains the only state with dominance in all components of power: economic, military, technological and social. It is the lone state with influence in almost every strategic region of the world (Huntington, 1999; Krauthammer, 2003). However, there has been a power reconfiguration at the global arena to the extent that it can be argued with a great measure of accuracy that the United States has lost its primacy in international politics. Toje (2010, p. 3) argued "In 2010, we are seeing the contours of a new multi polarity. The financial crisis has if anything increased the pace of this transition". 
Emerging countries are becoming more assertive in expressing their positions in global politics. The erosion of United States primacy was as a result of Bush's unilateral foreign policy posture ${ }^{1}$ (Grevi, 2009, p. 11; Turner, 2009, p. 164; Laidi, 2011, p. 3) and the global financial crisis with its attendant relative decline in Washington's economy (Grevi, 2009, p. 23; Toje, 2010, p. 3, Harrison \& Sepulveda, 2011; Layne, 2012). For Layne, the economic crisis has two significant impacts. Firstly, it symbolises power shift from west to east particularly with the emergence of China as a great power. Secondly, it has shown the vulnerability of the western economic liberalism championed by the United States (Layne, 2012, p. 203): "Some twenty years after the Cold War's end, it is now evident that both the 1980s declinists and the unipolar pessimists were right after all. The unipolar era has ended and the unipolar exit has begun" (Layne, 2012, p. 204). The declinists' preposition is in accordance with history. A unipolar global configuration has been a rare occurrence in world's history. Serfaty (2011, p. 7) posited "Unipolar systems have been historically rare and geographically confined". Consequently, there has been the emergence of new players in international politics. The emerging powers strive for regional hegemony, aspiration to a global role and the challenge of United States hegemony (Macfarlane, 2006).

Revisionist powers are usually unsatisfied with the status quo. They strive to distort the balance of power in their favour and they will be willing to use force to attain their desire if they feel the benefit outweighs the cost. "There are no status quo powers in the international system, save for the occasional hegemon that wants to maintain its dominating position over potential rivals" (Mearsheimer, 2001, p. 2). "There is ample evidence from all of the emerging powers of unhappiness with the existing structure of international politics. There has also been substantial consideration of the potential for cooperation among them ..." (Macfarlane, 2006, p. 41). It is not surprising therefore to see the formation of an association of emerging powers which comprises Brazil, Russia, India, China, and South Africa (BRICS). The "C" (China) in BRICS is particularly in the position to distort the structure of power in international politics. The words of Roubini (2009, p. 3) capture the current Chinese influence in the global arena:

China is a creditor country with large current account surpluses, a small budget deficit, much lower public debt as a share of GDP than the United States, and solid growth. And it is already taking steps towards challenging the supremacy of the dollar. Beijing has called for a new international reserve currency in the form of the International Monetary Fund's special drawing rights (a basket of dollars,

\footnotetext{
${ }^{1}$ The 2006 Gallup survey shows that prior to 9/11 to February 2002, most Americans believed United States had a positive image around the world. However, between February 2002 and February 2005, the percentage of the positive image perception plummeted from $79 \%$ to $48 \%$.
} 
euros, pounds and yen). China will soon want to see its own currency included in the basket, as well as the renmibi used as a means of payment in bilateral trade.

"Behind the dragon comes the elephant" (Renard, 2009, p. 29). India has emerged as the second largest economy in BRICS. In contrast to Russia and China, India is unlikely to witness challenges associated with population any time soon (Renard, 2009, p. 30). "On the way to exceeding even China, with a population of over a billion people and economic growth rate that is above the world average, India is readily identified as one of the growing powers of the twentyfirst century" (Amin, 2006, p. 69). A report titled Global Trend 2025: A Transformed World by the National Intelligence Council shows that in the next 15-20 years, India will seek a multipolar world order. It will emerge as a polar power and plays the role of an intermediary between China and the United States. India's global clout is a reflection of its recorded success in economic growth and democracy.

Russia, the successor of one of the Super powers during the cold war, an actor with enormous military capability particularly in terms of its possession of vast nuclear weapons, seeks to regain its influence in the international arena. "Russia is too big, too near, too nuclear, too wellendowed, and even too resentful and assertive to be ignored, let alone provoked" (Serfaty, 2011, p. 10). As a big country with large territory and huge population, Brazil had long recognised its destiny to play a major role in the international affairs. The core of Brazil's foreign policy is to attain the goal of a global power. This aspiration is derived from its soft power such as its economic strength and territory. "It has consistently eschewed the development of hard power, and especially of military power" (De Lima \& Hirst, 2006, p. 21) Similarly, Skak (2011) argued that Brazil often exercises its soft power through "territorial denial". Brazil denied the United States the utilisation of its aircraft bases and military facilities in the Amazon in 2002 and also showed opposition to the United States intention to use military bases in Colombia. The European Union (EU) with its powerful common currency is expected to play a somewhat vital role in the emerging order despite its current economic crisis. The EU still remains a force in international affairs despite the crisis. It is the largest trading bloc in the globe and its policies influence other states in the international system (Smith, 2003, p. 104). The ubiquity of the European Union across the globe is reflected in the European companies' subsidiaries across the world, the European Commission delegation in 130 countries, the widespread European literature and the 
popularity of the European Soccer leagues. The combined economies of the members make the European Union the largest global economy (Renard, 2009, p. 31)

It is only logical to illustrate that an attempt to understand the structure of power in global politics presupposes a good grasp of 'polarity' as a term. Toje viewed polarity as "the distribution of power among the actors in the international system" (2010, p. 7). Unipolarity has one dominant power centre; bipolarity has two. Multipolarity has more than two. Polarity reflects the distribution of power among major powers at the global arena. In the anarchic international system, states strive for power to attain a measure of influence in world affairs. It is against this background that Newnham and Evans (1998, p. 34) argued that "polarity implies that within a definable system certain actors are so important that they constitute 'poles' against which other actors have to respond by joining coalitions or remaining non-aligned". Thus a polar actor is one whose rapid decline would distort the structure of the system. Grevi defined poles as "states endowned with the resources, political will and institutional ability to project and protect their interests at the global level, multi-regional or regional level, depending on the size of the power in question" (Grevi, 2009, p. 19).

It is within this conventional context, that polarity was employed in this research. Most analyses of polarity focus on economic and military capabilities of the major players in the international system (Huntington, 1999; Krauthammer, 2002; Wohlforth, 2002; Posen, 2003; Bordachev, 2009; Grevi, 2009; Turner, 2009; Walt, 2009; Norrlof, 2010; Toje, 2010). This study seeks to continue with this tradition. Economic and military capabilities appear to be central in the measurement of states' power. However, there are other important components of power. There seems to be a dearth of literature in the comparative study of the great powers' soft power in Africa and the Middle East as studies on soft power often focus on a country case study particularly America or China (Nye, 2004a; Nye, 2004b; Gardels, 2005; Gill \& Huang, 2006; Yoshihara \& Holmes, 2007; Cho \& Jeong, 2008; Ding, 2008; Wang. 2008; Hunter, 2009; Paradise, 2009). In this light, the study explores the lacuna by analysing the soft power of the United States and China in Africa and the Middle East. In the words of Joseph Nye (2004a, p. 5 "this soft power - getting others to want the outcomes that you want - coopts people rather than coerces them". Hard power connotes the military and economic capabilities of states. Hard power is characterised by coercion while soft power reflects the attractiveness of a country's 
culture, political ideals and policies. A great power has to make its culture look attractive to others. Other nations must admire the culture and political ideals of the great powers. Owing to the ever increasing interdependence of the globe, soft power becomes important to ensure the cooperation of other states.

The structure of the international system has generated the interests of scholars around the globe. Quite a number of scholars argue that the international system is unipolar. Their position is premised on the argument that the United States is the only state with dominance in all components of power - military, economic, technological and cultural (Wohlforth, 1999; Krauthammer, 2002; Walt, 2009; Noorloof, 2010). Some other scholars look at global politics from the multipolar lens. Unlike the "primacists" (proponents of unipolarity), they posit that the United States has lost its primacy at the global arena, hence, the arrival of new players that compete with the United States at the global stage ( Wayne, 1993; Renard, 2009; Toje, 2010). The inadequacy of these models to explain the realities of the $21^{\text {st }}$ century led to the emergence Huntington's uni-multipolarity, Grevi's interpolarity and Haas' nonpolarity. In a uni-multipolar order, there is a sole-superpower and some major powers. Interpolarity connotes a multipolar structure characterised by functional interdependence. Nonpolarity emphasises an international system with many power centres (including both state and non state actors).

However, the study posits that these models are inadequate to explain the global politics of the $21^{\text {st }}$ century. It is within this context that the study seeks to examine a structure the researcher calls "uni-interpolarity" (a hybrid of uni-multipolarity and interpolarity) as an alternative model to explain contemporary global order. Grevi (2009: 9) described the current international system as the age of "interpolarity" which he defined as "multipolarity in the age of interdependence". He argues that multipolarity is not suitable to describe the emerging international system as climate change, terrorism and proliferation of nuclear weapons are environmental and security issues that require the collaborative efforts of the globe which exist outside the scope of multipolarity. Huntington (1999) described the structure of power at the global stage as unimultipolarity. He argued that the United States is the only superpower but that does not translate to a unipolar global framework. He maintained that the United States is the sole state with preponderance in all components of power. However, major issues at the global stage are settled by the sole super power in concert with other major powers. However, the superpower can 
"veto" the decision of the major powers. This research seeks to synthesise the two models. In this light, the study shall attempt to answer some crucial questions: Does the United States still maintain its primacy in the international system? In what direction is the power shift in contemporary global politics? Does uni-interpolarity serve as an alternative model to explain contemporary international politics?

\subsection{Statement of the problem}

Power has always been central to international relations. In an anarchic system, states strive to maximise their power in the global arena. The pattern of states' relation in the international system often reflects the structure of power in global politics. Scholars of international relations employ polarity to measure the distribution of power among states and alliances. It is a truism that all states are equal in the international system under international law. However, there exists a massive inequality among states in terms of power capabilities. Prior to the cold war, particularly in the 1700s and 1800s the pattern of politics in Europe reflected the multipolar configuration of the region. Great Britain, France, Russia and Prussia/Germany were the great powers. Austria-Hungary, Italy and Ottoman Empire were also powers to be reckoned with. This pattern of politics influenced states behaviour across Europe and ultimately in the global arena. The balance of power system to maintain the status quo or prevent the emergence of an empire with the capability to dominate Europe and the world was a salient feature of the multipolar system.

During the cold war, the ideological divide between the East and the West defined the world. The devastation incurred by the great powers after World War II led to the rise of the United States and USSR to the super power status. While the Soviet Union championed the Eastern bloc, the Western bloc was spear-headed by the United States. Global politics reflected the power tussle between the two super powers. This was particularly evident in the proxy wars around the world. The USSR was no match for economic prowess of the United States. However, the military capability of the two super powers was roughly equal. In addition, the Soviet Union had a powerful alternative ideology (socialism) to the United States capitalist system.

The end of the cold war and the aftermath demise of the Soviet Union gave birth to a unipolar configuration. Japan had risen to a major power primarily based on its economic success but now 
suffered major economic decline. Similarly, the German economy was not robust enough to challenge the most powerful state. This resulted in the preponderance of the United States in all components of power, particularly in terms of military and economic capabilities. In this era, the United States emerged as the undisputed hegemon in the international system.

The central concern of this study is to investigate the power configuration of the contemporary international system. The unilateralist war on terrorism in Iraq following the September 112001 terrorist attacks on the Pentagon and World Trade Centre in the United States has tarnished the global image of the United States. In addition, the global financial crisis has led to economic decline in the United States. The resultant effects on the structure of global politics have generated debate among scholars of International Relations. Scholars have propounded various models to explain the structure of contemporary international politics which take into cognisance the realities of the $21^{\text {st }}$ century. Against this backdrop, the research seeks to investigate the structure of power in today's world. In doing this, the research investigates the hard power (military and economic capabilities) of the great powers. A state's hard power is widely considered in the literature as the most important element of power capability. However, recognising the significance of soft power in today's world, this research seeks to analyse the soft power capabilities of the great powers. Soft power has become increasingly important as a result of the unprecedented interdependence in the global arena. In other words, in determining the power configuration of today's world, the research examines both the hard and soft power capabilities of the great powers.

\subsection{Research hypothesis}

This study was guided by the following hypothesis:

1) The contemporary structure of global politics reflects a hybrid of uni-multipolarity (a structure of power that consists of a super power and other major powers in which major decisions are taken by the super power in collaboration with the major powers, although the super power may "veto" the decision of the great powers) and interpolarity (multipolarity in the age of interdependence). 


\subsection{Research questions and objectives}

This research seeks to investigate the power configuration of the contemporary international system. Therefore, the proposed research attempts to address the following questions:

1) Does the United States still maintain its primacy in the international system?

2) In what direction, if at all, is the power shift in contemporary global politics?

3) What are the features of the $21^{\text {st }}$ century global structure of power?

4) Is uni-interpolarity a reality or rhetoric?

The research objectives of the study are to:

1) Assess the United States hegemonic posture in global politics;

2) Examine how the emerging powers are challenging the dominance of the United States;

3) Explore the power configuration of contemporary international politics; and

4) Examine uni-interpolarity as an alternative model to explain the contemporary global power configuration.

\subsection{Broader issues to be investigated}

A plethora of scholars have attempted to examine the structure of power in contemporary international politics. The focus of most analyses has been economic capability and military strength - hard power of the great powers (Huntington 1999; Krauthammer 2002; Wohlforth 2002; Posen 2003; Bordachev, 2009; Grevi 2009; Turner 2009; Walt, 2009; Norrlof 2010; Toje 2010). Little scholarly attention has been given to the great powers' ability to obtain desired foreign policy outcomes through means other than tangible threats or payoffs. Yet in an era of interdependence and information revolution, soft sources of power such as culture, political ideology, and diplomacy are increasingly of great relevance in attaining desired outcomes (Nye, 2004b: 17). Against this background, few scholars have tried to examine soft sources of power. What is missing in their studies is a comparative analysis of the dominant states' power as scholarly analyses on the issue are often limited to a single country (dominant power) case (Nye, 2004b; Gardels, 2005; Gill \& Huang, 2006; Yoshihara \& Holmes, 2007; Cho \& Jeong, 2008; Ding, 2008; Wang, 2008; Hunter, 2009; Paradise 2009; Nye, 2010; ). This research seeks to fill 
this gap by examining soft power of the United States and China in Africa and the Middle East. The research seeks to give a balanced view of the structure of power by examining both the hard and soft sources of power of the dominant states in international politics, particularly the United States and China. Particular reference is given to South Africa and Nigeria in Africa. The choice of these countries is informed by their power status in Africa. While South Africa has the most sophisticated economy in Africa, Nigeria has the largest economy and is the largest producer of oil in Africa.

In addition, most scholarly analysis on polarity in contemporary international system either argues that the international system is unipolar or multipolar (Krauthammer, 2002; Wohlforth, 2002; Posen, 2003; Walt, 2008; Bordachev, 2009; Turner, 2009; Norrloof, 2010; Toje, 2010). However, Grevi (2009) described the current international system as the age of "interpolarity" which he defined as "multipolarity in the age of interdependence". He argued that multipolarity is not suitable to describe the emerging international system as economic growth, energy security and environmental sustainability are vehicles of unprecedented interdependence. All these issues require the collaborative efforts of the globe. Multipolarity is inadequate to explain this "deepening interdependence". The limitation of his analysis lies in his under-estimation of the United States' power in the interpolar world order. Huntington (1999) posited that the models employed to analyse and understand international politics (unipolar, bipolar and multipolar) are insufficient to explain contemporary international politics. According to him, the United States is the only superpower but that does not translate to a unipolar global order. He maintained that the United States is the sole state with dominance in all components of power. However, major issues at the global stage are settled by the sole super power in concert with other major powers. He labeled his idea "uni-multipolar". Huntington's failed, however, to give importance to the role of states" interdependence (particularly the "dark side" of globalisation such as security and environmental issues) in shaping the global structure of power. Therefore, this research seeks to synthesise the two models. The synthesis will be given the term uni-interpolarity. Thus, the research examines the reality, rhetoric and the feasibility of a uni-interpolar world.

\subsection{Research methodology and methods}

The research adopted a number of methods and approaches. It largely employed qualitative and historical approaches. Neuman (1994, pp. 316-317) observed that "qualitative data tends to be in 
the form of words, sentences, and paragraphs rather than numbers". He further illustrated that "qualitative reports often contain rich description, colourful detail, and unusual characters; they give the reader a feel for social setting”. Bryman (2004, pp. 18-19) aptly described qualitative research as "a research strategy that usually emphasizes words rather than quantification in the collection and analysis of data". Qualitative research is characterised by an inductive approach involving the building of theories. It adopts interpretivism ${ }^{2}$ and constructionism ${ }^{3}$ in its epistemological and ontological considerations respectively. This approach appeared to be appropriate for this study because the primary mode of data collection involves in-depth interviews. Also, this approach was appropriate in that the inductive nature of the research intended to synthesise interpolarity and uni-multipolarity as an alternative model for the explanation and understanding of international politics.

In the words of Busha and Harter (1980, p. 90), the historical approach connotes:

systematic collection of data which is preceded by the objective evaluation of information related to past events so as to test hypotheses in regards to their causes and effects in order to be able to explain the present trends and have focus on the future.

This approach enhances the understanding of dynamism involved in events over time. Its relevance to this study is the understanding of the global structure of power in history, the current structure and the likely future configuration.

\subsection{Data collection}

Data for this study was generated through both primary and secondary sources.

\subsubsection{Primary sources}

The primary sources of data gathering for this study were personal in-depth interview, and interviews conducted by various media organizations which are available on the internet. The

\footnotetext{
${ }^{2}$ According to Bryman (2004, p. 13) interpretivism contrasts with positivism in its epistemological orientation. Positivism is widely employed by quantitative researchers. Positivists advocate for the application of the scientific model to the social world. Interpretivists posit that the unit of analysis of the social sciences (humans) is different from the natural sciences. The study of humans and their instituitons therefore requires a "research procedure that reflects this distinctiveness".

${ }^{3}$ Constructionism is a divergent ontological position to objectivism (perspective of quantitative researchers) which argues that "social phenomena confront us as external facts that are beyond our reach or influence" (Bryman, 2004: 16) Constructionism sees social reality as a social construct. It argues that people make sense of their own social reality.
} 
intention was to elicit rich, robust and detailed responses. The personal in-depth interviews were conducted with experts particularly in the field of international relations. These experts were significantly drawn from the two most important powers in global politics - the United States and China. Low cadre bureaucrats were also interviewed as they were often more accessible than higher cadre bureaucrats. In addition, primary data was used from the website of institutes such as the Stockholm International Peace Research Institute (SIPRI), World Bank, Freedom House, Pew Research Centre, the Gallup organisation and Eurobarometer. Relevant dependable interviews from the internet also formed part of the primary data. The researcher relied heavily on semi-structured interviews to elicit responses from the interviewees. In a semi-structured interview, "the researcher has a list of questions or fairly specific topics to be covered, often referred to as interview guide, but the interviewee has a great deal of leeway in how to reply" (Bryman, 2004, p. 321). Questions outside the interview guide can also be asked by the interviewer in a semi-structured interview. With regard to this study, responses from the interviewees provoked a series of consequential questions outside the confines of the interview guide. This enhanced the robustness of the study as the researcher had a measure of flexibility to ask insightful questions of relevance to the findings. Individuals representing three clusters of interviewees were interviewed. The first cluster included scholars and analysts of international relations from American, South African and Nigerian universities. The second cluster consisted of bureaucrats from the United States, South Africa and Nigeria. The third cluster comprised think tanks from Nigeria and South African research institutes.

Purposive or judgmental sampling was utilised in this study. Neuman (1994) asserted that purposive sampling "uses the judgment of an expert in selecting cases, or selects cases with a specific purpose in mind". It is used in exploratory research. He outlined three situations in which this type of sampling was appropriate. Firstly, "unique cases that are especially informative"; secondly, "members of a difficult to reach specialised population"; thirdly, identification of "particular types of cases for in-depth investigation". In this light, this study interviewed respondents that were relevant to the themes and research questions of the study. The difficulty in reaching some of the proposed interviewees informs the choice of this sampling method. 


\subsubsection{Secondary sources}

The secondary sources for this study were extracted from books, journal articles, conference proceedings, magazines and newspaper articles. Data gathered from these sources complemented and enriched the data from the primary sources. The combination of the sources was vital to the robustness of the study.

\subsection{Data analysis}

Data obtained from this study were subjected to content analysis. Weber (2004:117) viewed content analysis as "a research method that uses a set of procedures to make valid inferences from text". Neuman (2001: 49) viewed content analysis as the "technique for examining the content or information and symbols contained in written documents or other communication media." The following can be subjected to content analysis: books, newspapers or magazine articles, advertisements, speeches, official documents, films or video tapes. Content analysis is a very flexible method that can be applied to a variety of different media.

\subsection{Limitations}

The major limitation of this study was insufficient sources of primary data. This was as a result of either the unavailability or the unwillingness of diplomats in the American, Chinese, and the Middle Eastern countries' embassies to be interviewed by the researcher. This challenge was addressed by interviewing bureaucrats at lower echelons in Nigeria and South Africa. In addition, interviews with top bureaucrats, particularly in the United States, related to this topic were found on the internet. These were supplemented by interviews of scholars in the field of international relations.

\subsection{Delimitations/scope}

The study explores the structure of contemporary international politics from the vantage point of the end of the cold war and the attendant demise of the Soviet Union. The study interrogates the current status of the United States in world politics, the significance of the emerging powers particularly China and Russia, the counter-hegemonic role of the BRICS and the pragmatic relevance of the troubled European Union in the changing global order. 


\subsection{Structure of dissertation}

The current chapter (chapter one) is the introductory chapter of the thesis. The chapter lays the foundation for the research providing a context and background to the study. The chapter states the problem that informs the study, the fundamental questions the study seeks to investigate and the core objectives of the study. Furthermore, the chapter illuminates the methodology employed by the researcher to carry out the study. It also explains the method of data analysis, as well as the scope and limitation of the study.

Chapter two of the study provides a literature review. It engages with various items of scholarly literature related to the subject-matter of the research and endeavours to identify and fill a lacuna in the existing literature. In addition, the chapter identifies and provides justification for the choice of the theoretical and conceptual frameworks employed in this study.

Chapter three of the study provides a historical background of the global structure of power. The chapter explores the balance of power politics in the nineteenth and twentieth centuries with the primary objective to trace the different structure of powers in this period and possibly identify how they differ from the contemporary polarity in the next chapters.

The fourth chapter of the research explores the capability of the United States in terms of its hard power and soft power currencies. The objective is to determine whether or not the United States still wields enormous power in the global arena. The chapter also engages with the burgeoning literature on American decline. With the realisation of the growing importance of soft power, the chapter explores the extent to which the United States wields its soft power currencies in Africa and the Middle East.

The fifth chapter of the study seeks to examine the capability of the rising powers including their capability to shape the configuration of power in today's international system. Thus, the hard power and soft power resources of the BRIC countries were examined. The chapter identifies China as the most important player with the capacity to possibly compete with the United States. To this end, the chapter interrogates China's soft power in Africa and the Middle East.

The sixth chapter is the last substantive chapter of the research. The objective of the chapter is to outline the major characteristics of contemporary international system and to identify the model 
that can accommodate the features. Thus, the chapter investigates whether uni-interpolarity is adequate to explain today's structure of power.

The seventh chapter is the concluding chapter. It summarises the major findings of the research and reaches a conclusion. 


\section{CHAPTER TWO}

\section{A Review of Related Literature}

\subsection{Introduction}

After the treaty of Westphalia which brought into being the modern international system, the number of great powers has fluctuated between two and five (Rosenau \& Durfee, 1995). The number of great powers determines the structure of power in the global arena. In this light, the description of the cold war as bipolar generated little or no controversy among scholars and keen observers of international politics. There was widespread agreement that the pattern of international politics that characterised this era reflected the real politik between the two super powers. The structure of power in contemporary international politics is highly contested. A plethora of scholars have argued that the international system is unipolar. They claimed that the United States maintains preponderance in all components of power. They have argued that while other states may possess huge capacity in one or two elements of power, no state matches the completeness of American power in the military, economic, diplomatic and technological realms. A few scholars further reinforce this argument by pointing to the United States mastery of soft power as evident in the attraction of its culture and political values to other states. Other sources of its soft power include its entertainment industry, multinational corporations and its tertiary institutions.

Other scholars have posited that the contemporary global structure of power is multipolar. They have argued that the United States which emerged from the cold war as the only super power is in decline vis-à-vis the rise of the rest, most especially the emerging powers. These scholars have attributed the American decline to the United States' war on terrorism and the global financial and economic crisis that began in the United States in 2007. They further argued that China is the most important player that challenges America's global hegemony owing to, among other things, its rapid economic growth and its status as the second largest economy in the world. Some scholars have also argued that the traditional models for the explanation of the structure of powers are not adequate for describing contemporary international politics. It is within this context that Huntington's uni-multipolarity, Grevi's interpolarity and Haas's nonpolarity can be 
located. Against this background, this chapter seeks to review related literature on polarity in the international system.

\subsection{Unipolarity: The primacy of the United States}

The primacists argue that the United States remains the sole state with dominance in all components of power. They posit that the United States is the largest economy in the globe. The United States spends half of the world's military budget. It is within this context that we can locate the work of Krauthammer (2003) who demonstrated that the post-cold war era is characterised by unipolarity and rogue states that possess weapons of mass destruction. The end of the cold war led to the demise of the Soviet Union which gave birth to the weakened Russia. Other major powers such as Japan and Germany suffered major economic decline. He further argued that the European Union developed a process to expedite economic and social integration at the expense of military capacity. He posited that the situation left only China to be a significant player but it would take China decades to be able to challenge America's hegemony. This results in the "dominance of a single power unlike anything ever seen" (Krauthammer, 2003, p. 6).

Krauthammer (2003) further illustrated that America's primacy reached its peak after the September 11 attacks as a result of its unilateral posture after the event. He identified three reasons for this. Firstly, it invigorated the United States to flex its military muscles. In a matter of weeks, the Afghan regime was toppled. Krauthammer asserted that "in response America showed that at a range of 7,000 miles and with but a handful of losses, it could destroy within weeks a hardened, fanatical regime favored by geography and climate in the graveyard of empires" (Krauthammer, 2003, p. 7). Secondly, the quick recovery of the United States after the attack on its symbol of economic strength (World Trade Centre) was unbelievable and impressive. Even though the United States had been widely viewed around the world as an invulnerable state, the manner in which the United States was able to cope with the situation within days showed its resilience. Lastly, the United States was able to garner the support of the great power in its war on terrorism. Pakistan and India, which had previously had strained relationships with the United States, indicated their massive support for America after the devastating events. Russia and China also put their weight behind America. 
Wohlforth (1999) was of the opinion that the demise of the Soviet Union translated to the end of the bipolar order that had determined international relations among states after the Second World War. This event catapulted the United States to the status of the lone super power. He defined unipolarity as "a structure in which one state's capabilities are too great to be counterbalanced" (Wohlforth, 1999, p. 9). For him, to become a pole, a state must excel in all components of power such as military, economic, geographic and technological: "Two states measured up in 1990. One is gone. No new pole has appeared: $2-1=1$. The system is unipolar" (Wohlforth, 1999, p. 10). Several scholars have argued that unipolarity is inherently unstable, because other great powers will challenge the dominant power. Wohlforth, however, contended that unipolarity is peaceful and stable. He suggested that the United States can and should adopt a grand strategy of active engagement in world politics to maintain order and to prolong unipolarity. He argued that no state has the capacity to challenge the United States in all the major components of power in the coming decades. The desire to distort the unipolar structure by a great power or coalition of great powers will generate tension in their various regions which will engender the rise of other states in the regions to resist such an attempt. Wohlforth (2000) stressed his position on the dominance of the United States by arguing:

The United States is the only state today - and, indeed, the only state in modern international history that excels markedly and measurably in all the relevant power capabilities: military, economic, technological, and geopolitical. And the overall gap in material capabilities separating the United States from all contenders for polar status is larger than any analogous gap in modern international history. U.S. power is not unlimited, but it is unprecedented. (p. 4).

Similarly, Brooks and Wohlforth (2002) emphasised the United States' preponderance in the major components of power. In the military sphere, Washington enjoys preeminence in its nuclear arsenal, air and naval forces. Its budget on military research and development (R\&D) is unrivalled. This particularly makes it almost impossible for other great powers to be able to compete with the United States. They further argued that in the economic sphere, no great power in modern history achieved the current United States' dominance in global economy. The only exception to the rule was the United States itself after World War II in 1945. Brooks and Wohlforth noted that the distinctive feature of contemporary international politics is the dominance of the United States in all components of power. Prior to this era, dominance in the components of power were so evenly distributed among states to the extent that no state could lay claim to concentration of the major elements of power. They also pointed to the geographical 
strength of the United States. Washington is less susceptible to external aggression owing to its geographical location. It is surrounded by two great oceans and bordered by weak and friendly states. They identified China, Russia, Japan and Germany as the potential threat to the unipolar structure. However, efforts on the part of the challengers to catch up with Washington will cause security dilemmas in their various regions. This will ultimately trigger regional balancing. For them, even if China is eventually able to compete with the United States in the economic realm, China will still lag behind in other components of power. According to Brooks and Wohlforth (2002) "If today's American primacy does not constitute unipolarity, then nothing ever will. The only things left for dispute are how long it will last and what the implications are for American foreign policy" (p. 21).

The same standpoint was evident in Norrlof (2010, pp. 2-3) who claimed that "American hegemony is stable and sustainable". According to her, for over sixty years, the United States has been dominant in the globe. The United States has the largest economy, the most sophisticated military and the most important currency in the world. For her, the realities of today's world such as the decline in the strength of dollar, the emergence of China as a major player and the rise of euro cannot challenge Washington's primacy. She substantiates her position by pointing to the 1970s' prediction that the United States was in decline as a result of high inflation, high interest rate, military challenge from USSR and China, on one hand, and economic challenge from Japan, on the other hand: "Pessimists then, as today, underestimated the longevity of the American power" (Norrlof, 2010, p. 3). She was of the opinion that the United States occupies and enjoys its strategic position in the international arena because a number of major states are satisfied under its leadership. The unavailability of a candidate with the capacity to usurp America's position implies that the status quo is durable and steady. Unlike the prevalent description of America as a benevolent hegemon in the literature, Norrlof has illustrated that Washington benefits "disproportionately" from its hegemonic posture. For her, America benefits more than it contributes to "public goods" and it benefits more than the other states in the international system: “The United States is self-interested, not altruistic" (Norrlof, 2010, p. 3). "In alliances in a unipolar world", Walt (2009) defined unipolarity as an alliance:

... in which a single state controls a disproportionate share of the politically relevant resources of the system Unipolarity implies that the single superpower faces no ideological rival of equal status or influence; even if ideological alternatives do exist, they do not pose a threat to the unipolar power's role as a model for others. (pp. 91-92). 
Walt described this alliance further as:

A formal (or informal) commitment for security cooperation between two or more states, intended to augment each member's power, security, and/or influence. Although the precise arrangements embodied in different alliances vary enormously, the essential element in a meaningful alliance is a commitment for mutual support against some external actor(s). ( p. 86)

He identified the distinctive character of contemporary unipolar order. He argued that, unlike the previous unipolar structure, states' actions reflect not only the distribution of capabilities. The actions are also informed by the United States' geographical location, liberalism and its influence in history and international institutions. These peculiarities influence alliance formation in today's world. This is particularly obtainable owing to the United States preponderance in all components of power. With the addition of supplementary spending, the United States military budget outweighs the combined budget of other states. He argued that even though the United States faces double challenges - the war in Iraq and the economic meltdown, other major powers cannot challenge the United States' dominance which is evident in its command of the commons - "that is, the ability to operate with near impunity in the air, oceans, and space) and the ability to defeat any other country (or current coalition) in a direct test of battlefield strength" (Walt, 2009, pp. 92-93).

Put differently, the United States is the only country that can deploy substantial amounts of military power virtually anywhere - even in the face of armed opposition - and keep it there for an indefinite period. Moreover, it is able to do this while spending a substantially smaller fraction of its national income on defense than previous great powers did, as well as a smaller fraction than it spent throughout the cold war. (Walt, 2009: 97)

Walt identified three balancing choices available to weaker powers:

1) To form an alliance to counteract the unipole's influence;

2) To align with the unipole to support its interests or benefit from the unipole's power to pursue their own interests; and

3) To remain neutral.

When there is wide margin in a state's capability and its potential challengers, it requires a massive alliance to balance the dominant power. The formation of such an alliance involves huge cost and also problems associated with collective responsibility. Unless the unipole appears to be a threat to all the members of the alliance, each member of the alliance tends to free ride. In the eventuality of alliance formation, the dominant power may distort the alliance "by adopting a divide-and-conquer strategy: punishing states that join the opposition while rewarding those that 
remain aloof or support the unipole instead" (Walt, 2009, p.96). In addition to the structural hindrance, an alliance against the United States would also encounter a non-structural impediment. Walt argued that the United States is the only great power in the West; the other great powers are in Eurasia. The implication of this geographical reality is that the great powers in Eurasia are more concerned with one another's growing influence in their region. A number of them may view the United States as a viable ally to counter the potential threats of their powerful neighbours.

Posen, in Command of the Commons (2003), showed that "one pillar of US hegemony is the vast military power ${ }^{4}$ of the United States" (p.7). He illustrated that command of the common indicates the United State dominance in the military use of air, space and sea and can deter other states from the use of the commons. According to him, other states that threaten to deny the United States the use of the commons, will risk military battle with the US. "Having lost such a contest, they could not mount another effort for a very long time, and the United States would preserve, restore, and consolidate its hold after such a fight" (Posen, 2003, p. 8). The command of the commons enables the United States to "exploit" economic and military sources of power for the maintenance of its global status at the international system. According to him, command does not imply that other states cannot utilise the commons, particularly in peace time. Other states can amass military capabilities that can be used in the commons when the United States does not stand as an obstacle. He conceptualised command to imply that the United States enjoys greater proportion than other states in the use of the sea, space and air. This status enables Washington to deny or threaten the denial of the use of the commons to other states. He attributes the United States' dominant position in the global arena to its command of the commons. It empowers the United States to check its rivals and foes by constricting economic, military and political assistance available to them. Washington's command of the commons has enabled it to launch wars planned within a very short time as was evident in the 1993 intervention in Somalia and the 2001 war in Afghanistan following the September 112001 terrorist attacks.

\footnotetext{
${ }^{4}$ In 2011, the United States military spending was \$711billion, China spent \$143billion. Russia, India and Brazil had an expenditure of $\$ 71.9$ billion, $\$ 48.9$ billion and $\$ 35.4$ billion respectively. See Background paper on SIPRI military expenditure data, 2011.
} 
Wade (2003) observed that while many keen observers have analysed the superiority of America's military and political power in the unipolar order, "the empire has another face: the framework of international economic rules and rules making organizations" (p. 77). He asserted that globalisation has tilted the international economy in favour of the United States "by yielding disproportionate economic benefits to Americans and conferring autonomy on US economic policy-makers while curbing the autonomy of all others" (Wade, 2003, p. 77). He argued that the United States military superiority in the international arena is a reflection of the United States' disproportionate economic gain in the world economy. He posits that while there may be disapproval over the United States' role in the international arena, there appears not to be a credible alternative among the great powers to take the United States' position in the unipolar structure. The implication of this is that the global arena would be worse off if any American rival becomes the global hegemon, particularly because some of the actions of Washington are geared towards promoting general good. Nevertheless, United States' actions are often informed by its desire to promote its own interests in the global arena. He identified a number of actions taken by Washington to promote its interests which often run contrary to the interests of the other states in the international system. This includes America's position on climate change, as well as its invasion of Iraq partly to prevent Russian, French and Chinese influence in the oil-rich country. According to Wade:

The United States's single most important thrust since the 1970s has been for open capital accounts and freedom of entry and exit for financial service firms. The institution of these rules is causing a parametric shift in the whole world economy, resulting in the loss of ability of all states to resist other parts of the US agenda. The removal of restrictions on capital mobility, far from being a neutral policy, makes the adoption of an egalitarian capitalism under tight social regulation much more difficult, by weakening the means by which a national government could implement such a collective choice. (2003: 85)

The United States' opinion is dominant in the rules of international economic regime that shapes economic globalisation. These rules, for instance, make the US dollar the most important international currency. "Globalization so constructed frees the US government of constraints in key areas of economic policy while putting other states under tighter constraints" (Wade, 2003, p. 87). Burman (2008) was of the opinion that the end of the cold war and the subsequent disintegration of the USSR erected a unipolar structure of power in the international system. In spite of the initial economic difficulties and a measure of insecurity that clouded the United States' hegemonic posture, it was able to get back on track owing to the confidence that ensued 
with the arrival of the Clinton administration. There was a conscious and successful attempt to spread globalisation in form of economic (capitalism) and political (democracy) liberalism which served as the raison d'être to justify intervention in other states and to shape the international realm in accordance with American values. In the pursuit of this goal, multilateralism was often embraced. However, Bush's administration discarded multilateralism and opted for unilateralism in pursuit of Washington's interests. The September 112001 attacks served as an ideological cover to embark on unilateralist policies. In other words, the agenda of go-alone policies had been preconceived well before the historic 9/11 attacks. The unilateral posture, particularly Washington's activities in Afghanistan and Iraq, resulted in a change of perception of the United States as its image plummeted around the world.

With respect to the question of the durability of American empire, Burman (2008) asserted "more prosaically, the US is its own grave digger because the very success of the world system it has sponsored and imposed is generating new contradictions of wealth and power that are creating new challenges to American hegemony" (p. 71). In the economic realm, he identified the challenge to United States dominance as emanating from the Asian powers. In the cultural realm, he pointed to radical Islam as the major obstacle to American cultural values of individualism and consumerism. In the security sphere, he argued that United States' dominance is unquestionable. However, the threat posed by nuclear proliferation may turn out to be a major challenge to America. Nevertheless, he was of the opinion that there is no state that can challenge the dominance of the United States. A credible challenge might only arise from a coalition of states. However, the conflicts of interests among the members of a coalition would prevent them from having a common front which could distort the global order. This gives the United States the leeway to possibly ally with one against the other.

The divergence of interests between the rising powers gives the USA the opportunity to protect its position by playing them off against each other, a tactic which is a driving force of US foreign policy. It has shown diplomatic subtlety, for example, in capitalising on India's fear of China by extending nuclear cooperation to it and doing so while maintaining relations with Pakistan on whose cooperation it depends for success in the war on terror. The extension of NATO and cultivation of former Soviet republics has been successful in neutralising the threat from the Central Asia. The US has met the African challenge from China by developing its military capacities on that continent with the formation of an Africa Command that has already shown its willingness to intervene in pursuit of US interests that makes China's engagement seem timid by comparison. (Burman, 2008, p. 73)

He concluded that unipolarity or a self-regulating market system is not an option for contemporary world order as both systems do not ensure stability in the international system. For 
him, stability can only be ensured by the establishment of an international institution of many countries with a major power. He argued that the United States is the sole state with the capability to take the leadership role in such organisation.

Ikenberry, Mastanduno and Wohlforth (2009, p. 4) have observed that international relations experts have identified polar state (pole) to be a state that:

1) commands an especially large share of the resources or capabilities states can use to achieve their ends and that

2) excels in all the component elements of state capability, conventionally defined as size of population and territory, resource endowment, economic capacity, military might, and organizational-institutional competence.

It is also common knowledge among scholars that prior to 1945 , four or more states had the wherewithal to form poles. In the 1950s only two states had the capability and by the 1990s only one pole remained as the other pole disintegrated into smaller states. There is also wide agreement that no great power has been able to amass its power capabilities in all spheres to challenge the sole pole. This translates to the United States dominance in all important elements of power which they identify as one of the most important characteristics of $21^{\text {st }}$ century global politics. They argued that the current age of sole super power has been unprecedented in history as no other great power has enjoyed dominance in all components of power. While other states may challenge America's power in one area or the other, the completeness and sophistication of its capabilities is second to none. They further provided reliable indices to justify their position. In 2006, the United States' share of the entire world and the Great Powers' GDP were 25\% and $50 \%$ respectively. These figures reveal that the economic size of the United States is greater than that of any great power in modern history. The only exception was the United States itself after World War II ${ }^{5}$. Despite the US annual military expenditure outweighing the rest of the world combined, the United States only spent 4\% of its GDP in 2006.

In 2004 US military expenditures on R\&D were more than six times greater than those of Germany, Japan, France, and Britain combined. By some estimates over half of the military R\&D expenditures in the world are American, a disparity that has been sustained for decades: over the past thirty years, for example, the United States invested more than three times what the EU countries combined invested in military R\&D. (Ikenberry et al., 2009, p. 8)

The United States is the only great power with the capacity to maintain military presence in almost all strategic regions in the world. It enjoys military dominance over the sea, air and space.

\footnotetext{
${ }^{5}$ The other great powers were devastated by the war leaving the United States as the only major economic power
} 
Without the aid of the United States, no single state or concert of states can station a major force outside its own region. According to Ikenberry et al. (2009)

"The bottom line is that if we adopt conventional definitions of polarity and standard measures of capabilities, then the current international system is as unambiguously unipolar as past systems were multipolar and bipolar" (p.10).

\subsection{Multipolarity: The rise of emerging powers}

The rise of emerging powers and the apparent decline of the United States have triggered a debate on the extent to which the United States wields its influence in the global arena, hence, some scholars' description of the contemporary structure of power as multipolar. According to Toje (2010, p. 7) polarity is the "the distribution of power among the actors in the international system". He argued that the concept has always existed in human's history. He was of the opinion that the Peloponnesian wars and the war between Rome and Carthage are instances of bipolar configuration. He contended that "unipolarity was not an era, it transpires, but an interlude" (Toje, 2010, p. 3). He rightly observed that the end of the cold war and the demise of the Soviet Union left the world with a sole super power. He further illustrated that with the "shift" from unipolarity to multipolarity, the United States loses its status "as the United States steps down and the emerging powers ${ }^{6}$ step up into the great power category" (Toje, 2010, p. 4). The United States, China, India, Japan, Russia and the European Union are, in his opinion, the likely states to shape the terrain of today's global politics. He argued that the financial crisis has particularly triggered the new multipolar era. Brazil and Germany might also play a significant role in the new order. While he observed that a number of the emerging powers have internal or domestic contradictions which may counteract their aspiration for a global role, he argued that the European Union, however, has the least capacity to play an active role in global politics. The distinguishing factor between multipolarity on one hand and unipolarity and bipolarity on the other hand is the shifting of alliance. The flexibility inherent in the multipolar order enables states to move from one pole to the other. Therefore, the stability that characterises the bipolar system may elude multipolarity. The coming multipolarity may not be influenced by states' ideological dispositions as manifested in the bipolar order. There appears not to be a sharp antagonism between liberal democracy and authoritarian capitalism.

\footnotetext{
${ }^{6}$ Emerging powers are characterised by regional hegemony, the desire for playing a major role in the global arena and the challenge of the dominance of the United States.
} 
Similarly, Renard (2009, p. 13) identified three features shaping contemporary international relations. Firstly, the "emergence" of China, India, and Brazil and the "resurgence" of Russia which have tilted the architecture of global politics towards multipolaity. Secondly, deepening interdependence among states which was exemplified by the global financial crisis. Thirdly, "the development of a new structure of multilateralism". In his words, "the year 2001 symbolises particularly well the definite end of America 'unipolar moment' and the rise of multipolar order" (Renard, 2009, p. 13). He made reference to the September 11 attacks on the United States, the acceptance of China in the World Trade Organization (WTO) and the coinage of BRICS ${ }^{7}$ by Goldman Sachs, all in 2001, to substantiate his position. Renard (2009) explicated multipolarity in the context of the coming order. He argued that in today's world the United States still remains the sole super power but that will not prevent the emergence of a full-fledged multipolar order which was kick-started in 2001. According to Renard,

Today, the world is increasingly multipolar with the emergence of new actors on the global stage, including the BRIC, the European Union (EU), and various non-state actors, although it is not yet truly multipolar as the US remains the unique global superpower. This rising multipolarity will likely define the $21^{\text {st }}$ century, despite many persisting uncertainties about the coming order, especially regarding its shape - true multipolarity or asymmetrical multipolarity - and its rules - competitive or cooperative multipolarity. (2009, p. 7)

He argued that the emergence of great power and the subsequent forthcoming multipolar order, as well as the current interdependence of the international system, are consistent with history. The selection of 2001 as the end of the unipolar order is only symbolic, as the major events that are shaping the contemporary international system have been evolving for a long time. However, what differentiates today's interdependence from the previous one is its functional and systemic character. Functional interdependence implies that there are influential international organisations such as the United Nations (UN) and International Monetary Fund (IMF) that shape the choices and behaviours of states in the global arena. Today's interdependence is systemic owing to the limited resources being shared by states for their survival. The peril of environmental and security factors such as climate change and nuclear proliferation are issues

\footnotetext{
${ }^{7}$ On 16 June 2009, the heads of state of the BRIC countries (Brazil, Russia, India and China) held their first summit in Yekaterinburg, Russia. By the end of the summit there was a call for an equitable, democratic and multipolar world order.
} 
that require the collaborative efforts of states in the international community. This engenders comprehensive interdependence. Renard argued:

Comprehensive interdependence is global, existential and complex. It is global because it connects actors from the entire world; it is existential because the future of the system and its components is critically threatened (e.g. due to climate change); and it is complex because different types of interdependence (economic, functional, and systemic) co-exist at different levels between different actors. (2009, p. 15).

While Renard claimed that unipolarity has come to an end, he was of the opinion that the current structure has not become fully multipolar. The United States still maintains dominance and remains the sole superpower, a position it still has the wherewithal to maintain in the coming years. America's decline is real but it must be understood in relative terms. Although the effects of the financial and economic crisis on its economy are massive, Washington has been gradually recovering in recent times. The US military and soft power is second to none. It must also be understood that America's decline is not a reflection of its decay but it is largely as a result of the rise of the rest, particularly the emerging powers of China, India, Russia and Brazil. Renard stressed:

There is a great uncertainty with regard to who will emerge as a major power and when US dominance will become definite history. In fact, it is very likely that only a few countries will emerge as central hubs of the system in the 21st century, creating a sort of asymmetrical multipolarity with a distinction between dominant or central powers, major powers, regional powers and local powers. (Renard, p. 18)

Xinbo (2010) asserted that despite the fact that the global financial crisis is coming to an end, the downturn signifies an end to a unipolar order which had the United States' model of liberalism and global influence as its defining features. According to him, "the looming new era is characterised by the emergence of multipolar power structure, plural politico- economic model and multiple players on the international stage" (Xinbo, 2010, p. 155). The United States status in the global arena which was built on its economic and military capabilities has been declining in recent years. This was exemplified in the economic realm by the financial crisis and in the military sphere by the war on terrorism particularly in Iraq and Afghanistan (Xinbo, 2010, p. 155). The economic success story recorded particularly between 1999 and 2001 in the United States was cut short by the decline that has been strangling the economy from 2002 owing to its poor economic growth and the emergence of the Asian powers (China and India). He identified 
three ways by which the 2008 financial crisis illustrates the limit of the United States economy and the robustness of the economies of the emerging powers:

1) America had to depend on the financial support of some countries particularly China to be able to cope with the crisis;

2) China and the developing countries economic performance outstrips that of the United States; and

3) China and the developing economies championed the world's economic recovery.

According to Xinbo,

Broadly speaking, however, the financial crisis may be only an episode in the long-term change of the world economy. It can be argued that the crisis did not start a new trend, but rather expedited a preceding one, exposing the depth and breadth of the changes that have been brought about (2010, p. 156)

With the demise of the Soviet Union and the end of the cold war, there appeared to be no alternative to America's economic model of liberalism. However, the financial crisis unraveled the internal contradictions of the American economic system. The crisis reveals that states must participate actively in the economy. The economy should not be left in the purview of private individuals. The crisis was significant in its effect on the world's confidence in the US dollar as the most important international currency: "In the past, it was Washington that often pointed a finger at others' financial and economic policies. The financial turmoil has now given other countries the opportunity to shake their fingers at Washington" (Xinbo, 2010, p. 156). Many countries are beginning to be more assertive in expressing their distinctive positions in the international arena. There has been the call for more fairness and equity in the international financial system.

Even though China also experienced the economic impact of the financial crisis, it appears to have significantly benefitted from it. The Chinese economic model which embraces massive state intervention could cope better with the crisis than the United States market fundamentalism. The model now serves as an alternative to the American model. Its resilience in the 1998-1999 Asian financial crisis and the 2008 global financial crisis testifies to its current status in the international arena. The developing countries may now begin to embrace the Beijing model as an alternative to the Washington model. Owing to the crisis, the Chinese currency (renminbi) has gained wider significance primarily because of the loss of faith in the strength of the dollars in 
the international community. As a result of the crisis, China has had "bilateral currency swap agreement" with countries like Argentina, Belarus, Indonesia, Singapore and South Korea (Xinbo, 2010, p. 160). China has also been taking steps towards the regionalisation of the renminbi. Finally, Xinbo identified three factors that are shaping contemporary international politics. Firstly, the change in the structure of power. The unipolar order that shaped interactions among states after the demise of the Soviet Union has come to an end. He argued that the developing countries will play a more prominent role in today's order. Secondly, owing to the plummeted image of America following its unilateral posture after 9/11 and the loss of confidence in its economy as a result of the financial crisis, its leading role in global politics has dwindled and it can no longer have its way in the international arena. Thirdly, there are calls for a fairer and more equitable international political and economic order. States are more and more concerned about pragmatic policies that reflect the distinctive character of their domestic politics rather than adhering to a dogmatic ideology.

Similarly, Layne (2012) observed that the current economic crisis has had two major effects firstly, it has engendered the rise of the rest exemplified by China's emergence as a great power. Secondly, it has revealed the weakness of the United States economy. Layne asserted:

Some twenty years after the Cold War's end, it now is evident that both the 1980s declinists and the unipolar pessimists were right after all. The Unipolar Era has ended and the Unipolar Exit has begun. The Great Recession has underscored the reality of US decline, and only "denialists" can now bury their heads in the sand and maintain otherwise. (2012, p. 204)

Although the great recession is not the direct cause of American decline and the rise of the rest, the economic crisis has stimulated their root causes and intensified their impacts. He argued that the American decline is propelled by external and domestic factors. The external factor is the emergence of new players in the global arena and the shift of power in international economic architecture from the Western world to Asian countries. This marks the relative decline of the United States particularly with the emergence of China as the capable rival of the sole super power: "China's rise signals unipolarity's end” (Layne, 2012, p. 204). In its domestic sphere, "the driver of change is the relative-and in some ways absolute-decline in America's economic power" (Layne, 2012, p. 204). This is reflected in the American fiscal crisis and the loss of confidence in the strength of dollars to continually hold its status in the international market. The end of World War II signalled the economic and military dominance of the United States in the international system. Layne argued that Washington's unipolar moment first occurred in 1945. 
Except in the Soviet Union sphere of influence, the United States was dominant in the global arena. It enjoyed dominating power in the three regions that were strategic to its interests Western Europe, East Asia and the Persian Gulf. The United States attracted the world through its soft power capabilities and its influence on the major international organisations was significant to its success: "Following the Cold War's end, the United States used its second unipolar moment to consolidate the Pax Americana by expanding both its geopolitical and ideological ambitions" (Layne, 2012, p. 205). However, the advent of the economic recession has triggered the waning of America's economy and soft power. The current dominance it enjoys in the military sphere will also erode as a result of contestation from the emerging powers particularly China. According to Layne:

The evidence that the international system is rapidly becoming multipolar - and that, consequently, America's relative power is declining - is now impossible to deny, and China is Exhibit A for the shift in the world's center of economic and geopolitical gravity. China illustrates how, since the Cold War's end, potential great powers have been positioning themselves to challenge the United States... Objective indicators confirm the reality of China's rise, and the United States' corresponding relative decline. In 2010, China displaced the United States as the world's leading manufacturing nation - a crown the United States had held for a century. The International Monetary Fund forecasts that China's share of world GDP (15\%) will draw nearly even with the United States (18\%) by 2014. This is especially impressive given that China's share of world GDP was only $2 \%$ in 1980 and as recently as 1995 was only $6 \%$. Moreover, China is on course to overtake the United States as the world's largest economy. (2012, p. 205)

He argued that an important indicator of America's relative decline is the prediction that China would soon overtake the US as the world's largest economy.

... the Great Recession has made it evident that the United States no longer is an economic hegemon. An economic hegemon is supposed to solve global economic crises, not cause them. However, it was the freezing-up of the US financial system triggered by the sub-prime mortgage crisis that plunged the world into economic crisis. The hegemon is supposed to be the lender of last resort in the international economy. The United States, however, has become the borrower of first resort - the world's largest debtor. (Layne, 2012, p. 210)

Similarly Layne (1993), inspired by the theory of structural realism, argued that great powers would emerge to challenge the hegemon to distort the unipolar order and establish a multipolar global framework. He argued that this position is consistent with history and the available facts from history suggest that:

1) Unipolar systems contain seeds of their own demise because the hegemon's unbalanced power creates an environment conducive to the emergence of new great powers; and

2) The entry of new great power into the international system erodes the hegemon's relative power and, ultimately, its preeminence. (Layne, 1993, p. 7) 
The rise of great power is provoked by the international structural arrangement. Primarily two factors trigger the emergence of great power - differential growth rate and anarchy. While rising powers have the privilege to take decisions on becoming a great power, they are usually, however, restrained by the structural arrangement. States with the wherewithal to become a great power but who choose not to pursue the agenda are likely to be punished. To guarantee security and freedom of choice in the international system, competent states must pursue the status of a great power. The security dilemma that the concentration of power in a state creates, elicits other states to balance against the most powerful state. The unipolar moments in history justify this position. Layne (1993) argued that France and Great Britain in 1660 and 1860 enjoyed a comparable level of dominance the United States enjoyed after the demise of the Soviet Union. The French unipolar moment ceased with the emergence of Britain and Austria as great powers and Britain's unipolar moment vanished with the rise of Germany, Japan and America to great power status. Layne advocated that:

If the emergence of those great powers correlates strongly with uneven growth rates, the sameness effect, and balancing against hegemonic power, it can be expected that the present unipolar moment will be displaced by multipolarity within a reasonably short time. (1993, p. 17)

States in the anarchic international system are usually worried about the capability of a hegemon rather than its intentions: "The historical evidence from 1660-1714 and 1860-1914 strongly supports the hypothesis derived from neorealist theory: unipolar moments cause geopolitical backlashes that lead to multipolarity" (Layne, 1993, p. 32). The United States has two options to accommodate the rising power or prevent the emergence of the rising power to the status of a great power. While an attempt to pursue the second option may appear attractive and attainable, it is unsustainable as other challengers would emerge as a result of differential growth rate. In other words, the strategy of preponderance would wither away. The strategy of benevolent hegemony would not also be sufficient to avoid the rise of new great powers. Layne was of the opinion that any serious attempt by the US to undermine the rise of great powers would trigger global concern about the tyranny inherent in excessive concentration of power in the hands of the United States. As the United States always tries to dictate the pace in the international arena in accordance with its own interest, this threatens other states and consequently, they strive for great power status with the primary objective being to balance the power of the United States. In this light, "American grand strategy must be redesigned for a multipolar world" (Layne, 1993, p. 
47). Layne argued for a strategy that would protect the American interests during the shift from unipolar to multipolar order and which would ensure the Unites States plays significant role in the multipolar order.

Contrary to the wide assumption of the emergence of a unipolar order following the demise of the Soviet Union in the early 1990s, Bordachev (2009) argued that the structure of power that emerged in this period was one of multipolarity. For him, America's perpetual endeavours to create a unpolar order have yielded no positive result as the multipolar order has appeared to be durable. The recent decline of America in international politics could shape interactions among states in either of two ways: firstly, an attempt by the United States to become a global hegemon and secondly, extensive cooperation among the great powers in the international system. Before the demise of the Soviet Union, the super powers were superior in power capabilities to other great powers. The two super powers possessed roughly equal capabilities and they could balance each other out. In today's world, the sole surviving super power still possesses the majority of power in the global arena particularly in terms of its military and economic capabilities. In this regard, the power configuration that emerged in 1991 was not a classic multipolar order characterised by balance of power among great powers. However, Bordachev argued that the occurrence of a strict balance of power in multipolar configuration was a rare phenomenon in history. The point is striking enough to deserve extensive quotation:

What emerged in 1991 was therefore not a classic balance of power between multiple powers. But, in fact, multipolarity has rarely involved a perfect balance of power. Although Rome, Parthia and China in the first century were unequal powers, this did not prevent them from balancing each other in the world arena, helped by the geographical distance between Caesar's empire and the "middle state", and the fact that none had any desire to export their political culture to one another. In this respect, the 74 years between 1917 and 1991 were the exception rather than the rule. (Bordachev, 2009, p. 62)

The United States ambition to become a hegemon in the international system between 1991 and 2008 has always been countered by a state or coalition of states. Within the counter-hegemonic coalition, Russia was the most assertive power as was evident in its dominating role. America's ambition to promote its interests within the platform of international organisations like the United Nations was blocked by Russia and China between 1992 and 1999. The blockade was coordinated at the United Nations Security Council and prevented the United States from championing resolutions. Russia was occupied by its domestic problems in 1999, yet it was able to prevent the adoption of a Security Council Resolution designed to orchestrate military 
intervention in Yugoslavia. The inability of the United States to prevent the spread of nuclear weapons around the world, particularly in the Indian and Pakistani aggressive pursuit of nuclear power status, testifies to the emergence of a multipolar world. The United States attempt to establish unipolarity following the September 11, 2001 attacks was thwarted. The United States was able to garner the solidarity of the international community in its war in Afghanistan for the terrorist attack was interpreted as a threat to the existence of states. However, the United States' attempt to get the world behind it in its war in Iraq was rebuffed by the international community. It could not attract even the support of its allies in Europe. The consequent unilateral attack against Iraq, without the approval of the United Nations and its subsequent opposition by a plethora of countries such as France, China, Russia and a number of US allies around the world, created a major decline in positive image for the United States as its action in Iraq was widely considered as illegal. The dwindling global image was complicated by the United States-born global financial and economic crisis which has had devastating effects on the global economy.

\subsection{Alternative models: Uni-multipolarity, nonpolarity and interpolarity}

The inadequacies of the traditional models to capture some developments in contemporary international politics gave rise to alternative models. Huntington (1999) posited that the models employed to analyse and understand international politics (unipolar, bipolar and multipolar) were insufficient to explain contemporary global politics. According to him, the United States is the only super power but that does not translate to a unipolar global framework. He maintained that the United States is the sole state which dominates in all components of power. However, major issues at the global stage are settled by the sole super power in conjunction with other major powers. He called this "uni-multipolar". In a unipolar configuration, there exists one super power, there are no consequential major powers; however, there are several minor powers. This enables the super power to unilaterally take major decisions in the international arena without the challenge of a state or group of states. Huntington argued that this configuration was exemplified by Rome and China in East Asia. There are two super powers in a bipolar configuration. Issues in international politics reflect the relation between the two super powers as each super power champions a bloc and endeavours to increase its sphere of influence by wooing the non-aligned states. In a multipolar order, there are many major powers of relatively equal power capabilities that cooperate and compete with each other depending on how the issues promote or jeopardise 
their interests. Major decisions of international consequence are taken by the coalition of the major states. This was evident in European politics for many centuries. Today's global power configuration differs from all these aforementioned models. According to Huntington,

Contemporary international politics does not fit any of these three models. It is instead a strange hybrid, a uni-multipolar system with one superpower and several major powers. The settlement of key international issues requires action by the single superpower but always with some combination of other major states; the single superpower can, however, veto action on key issues by combinations of other states. (1999, p.36)

Even though the United States holds preponderance of power, there are major powers at a lower level that not only exert their dominance at the regional level but also wield influence at the global arena. However, the United States enjoys more influence than these states. He argued that countries like Germany, France, Russia, China, Japan, India, Brazil, South Africa and Nigeria fall in this category. In the third stratum are "secondary regional powers whose interests often conflict with the more powerful regional states" (Huntington, 1999, p. 36). He argued that Britain, Ukraine, Japan, Pakistan, Saudi Arabia and Argentina belong to this category.

While the most powerful actors in the unipolar, bipolar and multipolar configurations strive for the sustenance of the systems, there is contrary systemic behavior in the uni-multipolar order. According to Huntington,

In a uni-multipolar system, this is less true. The United States would clearly prefer a unipolar system in which it would be the hegemon and often acts as if such a system existed. The major powers, on the other hand, would prefer a multipolar system in which they could pursue their interests, unilaterally and collectively, without being subject to constraints, coercion, and pressure by the stronger superpower. They feel threatened by what they see as the American pursuit of global hegemony. American officials feel frustrated by their failure to achieve that hegemony. None of the principal power-wielders in world affairs is happy with the status quo. (1999, p. 37)

While the United States was able to act decisively and unilaterally in the global arena in the unipolar moment, it can no longer exercise such enormous power in today's world. Therefore, economic sanctions and military intervention are now often employed by Washington to attain its objectives. Sanctions require the support of other states to be successful. However, states are often reluctant to support the sanctions which prompts the United States either to unilaterally impose them (which jeopardises its economic interests and its cordial ties with its allies) or choose not to impose them, "in which case they become symbols of American weakness" (Huntington, 199, p. 39). The emergence of a counter hegemonic coalition is not feasible in a unipolar structure as a result of the inability of the other states to challenge the dominant power. 
It erupts in a multipolar order, if other states feel threatened by the capacity and behaviour of a state. However, it is a constant feature of a uni-multipolar world.

Huntington identified the effects of uni-multipolar order on the United States foreign policy. Firstly, it makes the United States realise that the unipolar moment is over, as is evident in the collaborative efforts required from other major powers to take major decisions at the global arena. Secondly, policies to promote benign hegemony (wherein American interests coincide with the interests of the rest of the world) must be abandoned. Seldom do American policies promote public goods; more often than not, they do not because of the moralistic tendencies of the American policies and, more importantly, because the United States is the sole super power whose interests may sometimes conflict with other states' interests. Thirdly, as the sole super power, the United States must marshal its resources to generate cooperation among the other states to take actions on global issues in a way that promote America's interests. Finally, the interplay of power and culture is significant in transatlantic relations.

Huntington has observed:

Virtually all major regional powers are increasingly asserting themselves to promote their own distinct interests, which often conflict with those of the United States. Global politics has thus moved from the bipolar system of the Cold War through a unipolar moment - highlighted by the Gulf War - and is now passing through one or two uni-multipolar decades before it enters a truly multipolar $21 \mathrm{st}$ century. $(1999$, p. 37$)$

Haass (2008) suggested that the reality of the $21^{\text {st }}$ century international politics can be interpreted through the prism of what he termed "nonpolarity". He defined nonpolarity as a world in which both state and non-state actors play active roles in determining global outcomes, a world dominated not by one or two or even several states, but rather by dozens of actors possessing and exercising various kinds of power: "Power is now found in many hands and in many places" (p. 45). Unlike the multipolar order which is characterised with few polar states that influence the pattern of global politics, the nonpolar order has many centres with significant power. Even though contemporary global structure of power seems like a multipolar system particularly when one considers the power capabilities of the dominant actors like China, the European Union (EU), India, Japan, Russia and the United States which account for 80 percent and 75 percent of the world's military budget and gross domestic product respectively. However, the realities of contemporary international politics reveals that power is more diffused as many power centres 
exist, among which are the non-state actors. For him, states have lost their primacy at the global stage. His line of argument is informative enough to deserve an elaborate quotation:

Indeed, one of the cardinal features of the contemporary international system is that nation-states have lost their monopoly on power and in some domains their preeminence as well. States are being challenged from above, by regional and global organizations; from below, by militias; and from the side, by a variety of non governmental organizations (NGOs) and corporations. Power is now found in many hands and in many places. In addition to the six major world powers, there are numerous regional powers: Brazil and, arguably, Argentina, Chile, Mexico, and Venezuela in Latin America; Nigeria and South Africa in Africa; Egypt, Iran, Israel, and Saudi Arabia in the Middle East; Pakistan in South Asia; Australia, Indonesia, and South Korea in East Asia and Oceania. A good many organizations would be on the list of power centers, including those that are global (the International Monetary Fund, the United Nations, the World Bank), those that are regional (the African Union, the Arab League, the Association of Southeast Asian Nations, the EU, the Organization of American States, the South Asian Association for Regional Cooperation), and those that are functional (the International Energy Agency, OPEC, the Shanghai Cooperation Organization, the World Health Organization). So, too, would states within nation-states, such as California and India's Uttar Pradesh, and cities, such as New York, S ao Paulo, and Shanghai. Then there are the large global companies, including those that domi nate the worlds of energy, finance, and manufacturing. Other entities (45) deserving inclusion would be global media outlets (al Jazeera, the BBC, CNN), militias (Hamas, Hezbollah, the Mahdi Army, the Taliban), political parties, religious institutions and movements, terrorist organizations (al Qaeda), drug cartels, and NGOs of a more benign sort (the Bill and Melinda Gates Foundation, Doctors Without Borders, Greenpeace). (Haass, 2008, pp. 45-46)

Rather than power being concentrated, it is widely distributed in the contemporary international system. The United States still remains the dominant power in the global configuration as is evident in its second to none military spending and its economy being the largest in the globe. In addition, Washington is the master of soft power particularly in the realm of culture. However, the wide postulation about the United States decline is a reality. The American status in the international system has been under decline. "The reality of American strength should not mask the relative decline of the United States' position in the world - and with this relative decline in power an absolute decline in influence and independence" (Haass, 2008, p. 46). The economic decline is manifested in the United States percentage in global imports and the projected dominance of the Asian powers in the world's GDP following the recorded high growth rates in these Asian countries, "a large number of which are growing at more than two or three times the rate of the United States" (Haass, 2008, p. 46). Also, the dollar hegemony in the international economy is under threat. The euro and pound are stronger than the dollar in terms of the value of the currencies. Most of the world's foreign exchange holdings are currently in other currencies, not the dollar. The dominance the dollar enjoys in the international oil market may also be later challenged by other currencies. This will further weaken the United States economy. In the military sphere, the September 11 attacks have illustrated that there is a gap between military 
spending and military capacity. Relatively little military spending by the terrorist group caused enormous and memorable damage to the dominant state in the world. According to Haas:

Power and influence are less and less linked in an era of nonpolarity. US calls for others to reform will tend to fall on deaf ears, US assistance programs will buy less, and US-led sanctions will accomplish less. After all, China proved to be the country best able to influence North Korea's nuclear program. Washington's ability to pressure Tehran has been strengthened by the participation of several western European countries-and weakened by the reluctance of China and Russia to sanction Iran. (2008, p. 47).

While the emergence of other great powers, powerful organisations and the United States' misguided policies have contributed to the rise of nonpolarity, globalisation has played a prominent role in shaping the global structure of power. Globalisation has turned the world into a global village as is evident in the movement of drugs, e-mails, greenhouse gases, goods, viruses, weapons and people across the world with little or no hindrance. Globalisation particularly facilitates nonpolarity in two ways. Firstly, states cannot totally monitor activities within their boundaries as social activities are now less constrained by geographical boundaries. This weakens the influence of the great powers. Secondly, the free movement empowers the non-state actors like energy exporters who have been able to amass wealth and terrorists who utilise the internet to recruit and train members. In today's reality, the strongest state in the international system does not have a monopoly on the use of force and its global influence is widely checked. Individuals and groups are becoming more and more powerful and influential on the global stage. Threats from terrorist groups, rogue states and energy producers will be a constant feature of the nonpolar world.

Grevi (2009, p. 9) identified the two sources of change at the global arena. Firstly, the emergence of new great powers in the international system has tilted the global structure of power to a multipolar order. Secondly, unprecedented interdependence which determines the prosperity and security of the major players and the entire international system. Even though these trends are not entirely new at the global arena, , the intensity with which they manifest in today's world has been unprecedented. These trends will significantly shape contemporary global politics. Grevi described the current international system as an age of "interpolarity" which he defined as "multipolarity in the age of interdependence". He argued that multipolarity is not suitable to describe the emerging international system as climate change, terrorism and proliferation of 
nuclear weapons are menaces that require the collaborative efforts of the globe which is outside the scope of multipolarity. According to Grevi:

Interpolarity is arguably a better illustration of the international system in the making than multipolarity, as it captures the shifting balance of power and the ensuing geopolitical tensions while highlighting the fact that the prosperity and security of all the major powers are interconnected as never before. On the other hand, it suggests a set of guidelines for the reform of global governance structures based on the respective interests of the main global and regional powers and on the potential for their convergence around concrete policy issues. As such, interpolarity is interest-based, problemdriven and process-oriented, as it focuses on the frameworks and procedures that could help bring about cooperative solutions to shared challenges $(2009$, p. 9)

After the September 11 attacks on the United States, the influence of Washington around the world has been weakened. The United States' influence in today's world is not commensurate with its power capabilities primarily as a result of a rapid decline in its international image following the unilateral policies of Bush's administration and "the shifting balance of power in the international system" (Grevi, 2009, p. 11). These two issues significantly undermine American global dominance. The first source of decline can be checked, if the United States pursues pragmatic foreign policy that will redeem its image across the globe. However, the second factor, aided by the United States-born 2008 financial and economic crisis, appears to be unstoppable.

The "asymmetric distribution of power" is an important driving force in contemporary international politics. The nature of the distribution prevents the major powers from employing unilateralism in the pursuit of their interests in the global arena. The implication of this is that collaborative efforts in the pursuit of state interests will be a significant feature of the forthcoming order. "Three issues lie at the core of global interdependence, namely the economy, energy and the environment" (Grevi, 2009, p. 24). How these issues and the curtailment of the proliferation of weapons of mass destruction are handled by the international community will define the course of the $21^{\text {st }}$ century. The financial crisis that had its roots in the United States but had a global effect, signifies the extent of interdependence across the globe.

"Multipolarity and deepening interdependence" will shape the international politics of the $21^{\text {st }}$ century. If multipolarity has not fully emerged, its full-blown emergence is irreversible. What may appear to be a subject of debate is the nature of the multipolar order. Will it be confrontational, competitive or cooperative? While all these factors may manifest in the multipolar order, the promotion of cooperation is crucial most especially with issues that require 
the collaborative efforts of states such as economic, security and environmental factors. Interpolarity describes this order. According to Grevi:

Interpolarity differs from multipolarity given its focus on the challenges of interdependence and it differs from nonpolarity because it puts the accent on the relations between large state actors, while not neglecting the importance of trans-national relations. (2009, p.28)

Interpolarity advocates collaborative efforts among states towards addressing fundamental issues such as economic, security and environmental concerns in the global arena. It argues that the interests of the major powers converge in these spheres. No single state, irrespective of how big or powerful, can single-handedly resolve these issues. Challenges that arise from energy security, development, food security and migration flows will shape international relations in the contemporary world. In this regard, interpolarity is "interest-based and problem-driven" (Grevi, 2009, p. 28)

\subsection{An assessment}

With the end of the cold war, the United States emerged as the most dominant power in the international arena. Not only could the power capabilities of the United States, both in terms of hard power and soft power, not be matched but also its influence was global. In other words, the immediate post-cold war era witnessed the dominance of a single power in global affairs. With its domination of power, Washington was able to pursue its interests and the interests of its allies with little or no hindrance. In this context, the description of the immediate post-cold war era as unipolar global configuration by scholars is accurate. While proponents of unipolarity in the early 90s to around 2001 accurately described the global configuration of power, the defenders of unipolarity in recent times such as Noorloof (2010), Burman (2008) and Walt (2009) have greatly exaggerated the power capabilities of the United States. In fact, Layne (2012) and Nye (2012) observed that the proponents of unipolarity even in the early 1990s magnified the capabilities of the United States. Undoubtedly, the United States is the sole dominating power in all major spheres. However, in contemporary international politics, there exists a gap between the United States' power and its influence in the global arena.

The decline in the United States influence was particularly triggered by the war on terrorism, perpetuated by Bush's administration and complicated by the "United States-born" global financial and economic crisis. The George Bush war on terrorism, particularly in Iraq, was 
resented across the globe primarily because it was based on a unilateral decision. The United States was able to garner the global legitimacy it required in the war against Afghanistan through the approval of the United Nations. However, in defiance against the decision of the United Nations, it embarked on the war in Iraq. This singular event has shaped global politics to the extent that some scholars argue that the world changed after this historic event. Perhaps, Washington unilateralism after 9/11 informed the formation of BRICS. Countries like China and Russia realised it was imperative to check the power of the United States. The traditional allies of the United States also openly criticised the United States' war in Iraq. The image of the United States which had not been well managed in the Muslim world, further significantly plummeted after the unpopular war. The global economic crisis which started in the United States and its attendant global recession has highlighted the resilience of the economies of the emerging powers. While the West is still battered by the economic crisis as is evident in some European Countries, emerging powers like China and India who were also hit by the crisis had a speedy recovery (Layne, 2012). The crisis has revealed the weakness of Western liberalism and perhaps posits the Chinese model as a substitute to the Western market fundamentalism which has ignited the current global recession.

In this light, to describe the current global structure as unipolar would be erroneous and an oversimplification of events in today's world politics. Huntington (1999, p. 35) suggested that "a unipolar system would have one superpower, no significant major powers, and many minor powers. As a result, the superpower could effectively resolve important international issues alone, and no combination of other states would have the power to prevent it from doing so". The ongoing conflict in Syria has proven that the United States alone cannot single-handedly resolve issues of international consequence. In contrary to the position of Washington, Moscow and Beijing have been able to prevent the intervention of the international community in Syria.

There has been significant distribution of power among the major powers in the global arena. For instance China and India have indisputably emerged as economic powers in the international system. The military budgets of the emerging powers have also skyrocketed in recent times. Russia is also a powerful force with its vast possession of military and nuclear arsenals. However, contemporary international politics does not reflect a multipolar global framework. Huntington (1999) argued that "a multipolar system has several major powers of comparable 
strength that cooperate and compete with each other in shifting patterns. A coalition of major states is necessary to resolve important international issues" (Huntington, 1999, pp. 35-36). The United States remains the only state with dominance in all components of power - military, economic, diplomatic, technological and cultural. The decline of the United States power capability, as observed by Nye (2012), must be understood in relative terms. It is also important to note that, as the emerging powers are rising, other minor or middle powers such as Indonesia, Mexico, South Africa and Saudi Arabia are also rising. If the popular rise of China (oft-cited in the literature) is that consequential to the structure of power, then the global configuration should be a bipolar order. In other words, as China is rising to contest the dominance of Washington, other minor powers are also rising to challenge Chinese dominance. In this light, despite the devastating impact of the George Bush unilateral foreign policy and the economic crisis, the United States still remains the most important player in the global arena. This is evident in the global impact of the financial crisis that started in the United States. America remains the only state with military presence in all strategic regions in the world. Whereas the economic rise of China is applaudable, it is important to be mindful of the composition of the economy. For instance, the majority of the Chinese population live in rural areas, China's Gross National Income per capita is not commensurate with its status as the second largest economy and, above all, China is still regarded as a developing country.

The limitation of Haass' nonpolarity is its overestimation of the power of the non-state actors. As he rightly argued, the primacy of the state in today's world is being threatened. However, the non-state actors cannot be convincingly argued to be powerful enough to become polar powers. Moreover, the activities of the non-state organisations may be strengthened or undermined by the state actors. Huntington's uni-multipolarity underplays the current functional interdependence in the global arena. The contemporary international system is characterised by interdependence, engendered by issues that require the collaborative efforts of states in the international system. For instance, no state can single-handedly combat international terrorism and climate change. This deepening interdependence shapes the structure of power in the international arena. The roles that are played by non-state actors in the uni-multipolar order are not indentified in Huntington's analysis. In other words, while Huntington emphasised the distribution of powers among states in the international system, he was silent on the significance of non-state actors such as international organisations and multinational corporations. 
The limitation of Grevi's analysis lies in his underestimation of the United States' power in the interpolar world order. Despite the perceived United States' decline, it is still the most important power and no other country equals the completeness and sophistication of Washington's power. Even though the nature of contemporary interdependence lessens the extent to which a state can embark on unilateral policies, Grevi agreed that "core national interests" of a great power which are conflictual with the general interests of the other great powers are seldom promoted (2009, p. 29). He did not, however, indicate the extent to which each of the great powers can promote its core interests to the detriment of the general interests. In this light, the United States has shown, more than other great powers, its capability to take unilateral decisions of global consequence, most especially during Bush's administration. The Obama administration has generally adopted a multilateral posture in its foreign policy. As Nau (2010) rightly observed:

American foreign policy swings like a pendulum. Under President George W. Bush, US foreign policy promoted a democracy agenda, used force readily to buttress and at times even displace diplomacy, championed free markets, and risked if not relished unilateralism. Under President Barrack Obama, US foreign policy has swung decisively in the opposite direction. Now, US security interests matter more than democracy, force is a last resort, substantial regulations are needed to end the booms and busts of global capitalism, and multilateralism is the sine qua non of US diplomacy. (p. 1)

However, Obama's posture of multilateralism came under serious questioning when the United States unilaterally killed Osama bin Laden on May 1, 2011. This highlighted the willingness and capability of the United States to act unilaterally and decisively to promote its interests around the world. Washington also remains the only state with sophisticated capabilities in all components of power and is the only state with the capacity to maintain military presence in all strategic areas of the world.

Against this background, this study seeks to synthesise uni-multipolarity and interpolarity. The synthesis will be referred to as uni-interpolarity in the context of this study. Renard (2009) argued that while the unipolar moment is over, the current power configuration is not multipolar. He labelled it as "fading uni-multipolarity in the age of comprehensive interdependence" (2009, p. 18). He argued that the United States is still the most important player in international politics and will maintain this status for years or decades. He further posited that the United States is in decline and the emerging powers of BRICs are rising. Another feature of this era, he observed, is the functional interdependence of states. He argued, however, that whether cooperative or competitive, multipolarity will emerge in the near future. This study departs a little from Renard's in its analysis of the existence of a stable uni-multipoalrity in contrast with Renard's 
fading uni-multipolarity. Similarly Nye (2012) argued that the end of the cold war resorted in a power configuration which could be likened to a "complex three-dimensional chess game" (p. 215). The top chess board is the realm of military power which is unipolar and the United States is indisputably the dominant power in this realm. The middle chess board is the sphere of economic power which is multipolar and has the United States, Europe, Japan and China as the most important players. Finally, the bottom chess board is the domain of transnational relations that are beyond governmental control. Non-state actors, such as terrorist organisations and global threats like climate change, fall within this realm. While Nye's analysis encompasses the unipolar, multipolar and interpolar features of this study, he confined his analysis of the unipolar and multipolar arena to the military and economic capabilities of states. However, this study considers both the hard power resources, which include economic, military, diplomatic and soft power currencies in the triangulation of these models. Owing to the centrality of soft power in this study and also because most studies on polarity have focused on hard power resources, a review of soft power will not be out of place in this study. Therefore, the following section explores Nye's concept of soft power and how other scholars have applied this to the United States and China.

\subsection{Nye's 'Soft Power': The significance of power of attraction in international politics}

As presented earlier, most studies on polarity focus on the hard power status of the great powers, which is evident in the literature reviewed thus far. Since a major concern of this study is to investigate both the soft power and hard power resources of the great powers, a review of the soft power of the major powers becomes imperative. The concept of soft power was coined and popularised by Nye. Nye (2004a) identified and distinguishes two types of power - hard power and soft power. He argued that hard power was primarily derived from the economic and military capabilities of states. "Hard power can rest on inducements (carrots) or threats (sticks)" which enables a state to influence other states. However, a state may attain its desired objectives in relation to other states through intangible resources. This is primarily because other states admire its values, culture and policies and long to be like it. In other words, to influence other states in international relations, a state cannot only rely on threats of economic sanctions and military force. The state must be equipped with the resources that attract other states (soft 
power). Nye argued that hard power and soft power can also be referred to as command power and co-optive power respectively. Nye observed:

Command power - the ability to change what others do - can rest on coercion or inducement. Cooptive power - the ability to shape what others want - can rest on the attractiveness of one's culture and values or the ability to manipulate the agenda of political choices in a manner that makes others to fail to express some preferences because they seem to be too unrealistic. The types of behavior between command and co-option range along a spectrum from coercion to economic inducement to agenda setting to pure attraction. Soft power resources tend to be associated with the co-optive end of the spectrum of behavior, whereas hard-power resources are usually associated with command behavior. (2004a, p. 7)

To ensure cooperation of states, soft power is derived from resources other than force or money. Soft power employs attractive resources that draw other states to a state that masters the use of the co-optive currencies. A state that commands the power of attraction particularly through its culture, values and domestic and foreign policies, will be able to draw other states to promote its interests in the global arena. "Simply put, in behavioural terms soft power is attractive power. In terms of resources, soft power resources are the assets that produce such attraction” (Nye, 2004a, p. 6). Nye further argued:

Much as Adam Smith observed that people are led by an invisible hand when making decisions in a free market, our decisions in a market place for ideas are often shaped by soft power - an intangible attraction that persuades us to go along with others' purposes without any explicit threat or exchange taking place. (2004a, p. 7)

In the realm of international politics, soft power resources are derived from the values inherent in a state's culture which it promotes at the global arena, the standard it sets by its domestic policies and the nature of its interaction with other states in the international system. Soft power explains why some countries enjoy a powerful status in international politics that is not commensurate with their economic and military might. This is usually a reflection of those states' attractive foreign policies in global politics which may include economic aid and peace keeping.

Nye showed that a state can project its soft power through the platform of international institutions. This was particularly evident in British and American foreign policies behaviour in the $19^{\text {th }}$ and $20^{\text {th }}$ centuries respectively. The great powers promoted values that reflected the liberal and democratic principles of their economic system. While Britain campaigned for free trade and the gold standard, the United States promoted the International Monetary Fund (IMF), the World Trade Organisation (WTO), and the United Nations (UN). The legitimacy of a state's power in the international system enables it to promote its interests with little or no opposition. 
The appealing attribute of its culture and ideology guarantees the willingness of other states to cooperate and support it. Nye observed:

The soft power of a country rests primarily on three resources: its culture (in places where it is attractive to others), its political values (when it lives up to them at home and abroad), and its foreign policies (when they are seen as legitimate and having moral authority). (2004a, p. 11)

While trade is an important avenue to diffuse or transport culture, culture can also be transmitted via personal contacts, visits and exchanges. Universities play a significant role in this regard. Universities, particularly in the United States, attract many foreign students from across the globe. These students often internalise the culture of the foreign country. Government policies can boost or erode a country's soft power. Government policies that reflect the narrow interest of a state with little or no consideration of the preferences of other states will weaken a state's soft power. This was evident global image of the United States plummeted following the 2003 unilateral war in Iraq which received wide condemnation even among the United States western allies. Nye further claimed:

The values a government champions in its behavior at home (for example, democracy), in international institutions (working with others), and in foreign policy (promoting peace and human rights) strongly affect the preferences of others. Governments can attract or repel others by theinfluence of their example. (2004a, p. 14)

\subsection{The United States and China's soft power}

One of the central objectives of this study is to investigate the degree to which the United States and China wield their soft power capabilities in strategic regions. Therefore, it is important to examine the existing literature on these great powers' soft power. Nye (2004) indicated that the United States wielded enormous soft power in the international system during the cold war. The United States' soft power resources attracted allies across the globe. Not only did the United States rely heavily on its hard power currencies - military and economic might - it also depended on its soft power resources. However, in today's world, the American soft power is in decline, as demonstrated in anti-Americanism around the world. The decline of Washington's soft power reflects the post-cold war unconscious efforts to invest in soft power. The US's soft power plummeted after the September 112001 attacks. Nye claimed:

Between 1989 and 1999, the budget of the United States Information Agency (USIA) decreased ten percent; resources for its mission in Indonesia, the world's largest Muslim nation, were cut in half. By the time it was taken over by the State Department at the end of the decade, USIA had only 6,715 employees (compared to 12,000 at its peak in the mid-1960s). During the Cold War, radio broadcasts funded by Washington reached half the Soviet population and 70 to 80 percent of the population in 
Eastern Europe every week; on the eve of the September 11 attacks, a mere two percent of Arabs listened to the Voice of America (VOA). The annual number of academic and cultural exchanges, meanwhile, dropped from 45,000 in 1995 to 29,000 in 2001. (2004b, p. 17).

Similarly, Gardels (2005) argued that globalisation has not only facilitated deterritorilalisation the weakening of states boundaries and territories - but it has also influenced the nature of power in contemporary international politics. While military might has always been connected with the defense or conquest of territories or border, in a borderless modern international system, power is derived from economic might and consent - soft power.

If hegemony is not consensual in this new domain, it won't long last. Without legitimacy conferred by consent, the political objectives for which military might is deployed, and for which a society's wealth must pay, cannot be met. The ability to dominate one's environment - power - is thus frustrated, if not entirely defeated. The manifest powerlessness of the sole superpower to establish order, no less democracy, in Iraq is a dramatic illustration of this point. (Gardels, 2005, p. 8)

The United States relied on consensual hegemony during the cold war to promote its interests across the international system. Its ideas, which included freedom, rule of law, social and economic opportunity, served as the basis to enjoy the consensual hegemony. These ideas were the antithesis to fascism, communism and decolonisation. While American soft power reached its peak in the immediate period after the cold war, as evident in the influence of MTV and CNN in the global arena, challenges to Washington consensual hegemony can be seen in the rise of $\mathrm{Al}$ Jazeera and the Chinese-Language internet. These challenges are further strengthened by the United States decline in positive image in the Muslim world and the world at large, most especially after the war in Iraq. Nye (2002) showed that the information revolution has provided the platform for non-state actors to significantly influence international affairs.

Power is increasingly distributed between state actors and non-state actors. The distribution of power is driven by the unprecedented spread of information. Non-governmental organanisations (NGOs) have widely benefited from the flow of information in that this has facilitated their possession of soft power. While these organisations lack hard power, they possess soft power that attracts their audience. The United States' soft power prior to and during the cold war was largely derived from private organisations.

Government policies can either strengthen or undermine soft power. For instance the racial segregation of the 1950s undermined Washington's soft power in Africa. Capital punishment also weakened America's soft power in recent times in Europe. Unilateral foreign policy 
significantly undermined the United States' soft power. The United States will strongly benefit from the information revolution as long as its domestic and foreign policies reflect democracy, human rights and openness.

Huang \& Ding (2006) have argued that most scholarly work on China's power status and global influence have focused on hard power and this informs their analysis of China's soft power currencies. They argued that soft power has become particularly significant in this age of globalisation and information revolution. They posited that the Chinese culture has been widely assimilated in East Asia and in some Southeast Asian countries. The Chinese soft power currencies include its language, culture, and its economic growth and development model. There have been massive increases in the enrollment of foreign students in China. The Chinese language has also been successfully promoted in the global arena. Confucius Institutes have been established around the world to promote Chinese culture and language. Similarly, Gill \& Huang (2006), in identifying the sources and limits of Chinese soft power, have asserted that in 2005, 32 Confucius Institutes have been established by China in 23 countries. In addition to the promotion of Chinese culture and language, the institutes have the responsibility to promote a benign and benevolent image of China to the world. The Chinese economic model of authoritarian capitalism has catapulted China into the centre of economic power. The image of prosperity in this model has attracted other states. The enrolment of foreign students has been on the rise.

Within a decade, total enrolment of international students in China (excluding those from Hong Kong, Taiwan and Macau) increased threefold to $110,844.6$ Over $75 \%$ of students are from Asia, with South Korea and Japan consistently sending the most. A growing number of students, though, are from Southeast Asia, a region that accommodates the majority of overseas Chinese and has a centuries- old history of Chinese-language education. (Gill \& Huang, 2006, p.: 18)

Despite China's soft power potentials, there are major obstacles to the ability of China to effectively wield its soft power currencies. These include "imbalance in resources, legitimacy concerns of its diplomacy, and a lack of a coherent agenda" (Gill \& Huang, 2006, p. 26).

According to Cho and Jeong (2008) the rise in China's regional influence in recent times is not merely a reflection of its hard power resources; its soft power currencies are equally important. The promotion of Chinese culture and values has been a significant contributor to Chinese strength in the region. The Chinese image has been highly enhanced by the realisation of the Chinese officials of the importance of soft power and its subsequent application to national and 
regional policies. "Today, China's soft power is dependent on the following three resources: the Chinese developmental model, foreign policy centered on peaceful rise or peaceful development theories, and Chinese civilization" (Cho \& Jeong, 2008, p. 461). Among others, policies implemented to attract countries in Southeast Asia include aid, enrolment of international students and playing an active role in regional organisations like the Association of South-East Asian Nations (ASEAN). Chinese rapid economic growth has also largely contributed to China's influence and image in the region. Cho and Jeong (2008) examined and analysed various surveys such as the Pew Research Centre and the BBC World Service Poll to illustrate a massive improvement of China's image in Asia.

Against this background, few scholars have tried to examine soft sources of power. What is missing in their studies is a comparative analysis of the dominant states' soft power as scholarly analyses on the issue are often limited to a single country (dominant power) case. This research seeks to fill this gap by examining the soft power of the United States and China in Africa and the Middle East. The research seeks to give a balanced view of the structure of power by examining both the hard and soft sources of power of the dominant states in international politics, particularly the United States and China.

\subsection{Theoretical and conceptual frameworks}

Scholars have always strived to establish regularity in their various fields in order to enhance understanding, explanation and prediction. It is within this context that we can locate the various theories utilised by scholars of international relations to explain and predict the global structure of power. Notable among these theories is one of the mainstream theories of international relations: realism. Theories such as hegemonic stability theory and power transition have also been propounded to explain the international system. In the words of Morgenthau (1985, p. 3) "the history of modern political thought is the story of a contest between two schools that differ fundamentally in their conceptions of the nature of man, society and politics". These schools are realism and idealism. Realism explains international relations in terms of power. Realists argue that the anarchic ${ }^{8}$ nature of the international system triggers power politics among states. Realists are pessimistic about human nature. They view human nature as evil and emphasise the

\footnotetext{
${ }^{8}$ Anarchy in the international system refers to a lack of central authority that can enforce rules that are binding on states.
} 
inevitability of wars among states. The anarchic nature of the international system encourages states to acquire weapons to guarantee their safety. The acquisition of weapons by a state threatens the security of other states (security dilemma). This creates an arms race as states build arsenals to ensure their safety as they cannot rely on the help of other states for their security (self-help system). Realism is arguably too broad for this study and there are other theories that address more specifically its subject matter.

Power transition theory explains the occurrence of wars among the major powers in the international system. It emphasises the almost indispensability of war between great powers that possess almost equal capability. War is most likely when a rising power contests or overtakes a declining hegemon. The challenger strives to distort the rules of the international system in its favour. The declining hegemon attempts to maintain the status quo. The conflictual interests eventually lead to war between the two powers (Chan, 2004). In their explanation of power transition theory, Goldstein and Pevehouse (2008, p. 56) revealed that "the largest wars result from challenges to the top position in the status hierarchy when rising power is surpassing (or threatening to surpass) the most powerful state". With respect to the relevance of this theory to the study, it is not too clear, on one hand, if China will be able to surpass the United States' status as the most important actor in the international system. On the other hand, the overthrow of the United States by China as the dominant power may not necessarily be conflictual, particularly in an age of interdependence.

Hegemony stability theory posits that hegemony establishes an order that can be likened to a central government in the international system: mitigating anarchy, deterring aggression and promoting free trade. The hegemon holds preponderance of power and can unilaterally take decisions of global consequence. This theory ascribes the peace and prosperity that ensued after World War II to US hegemony (Goldstein \& Pevehouse, 2008, p. 58). Hegemony exists in a unipolar world as no state can lay claim to hegemony in a bipolar or multipolar configuration. Thus, this theory does not apply to this study because in the contemporary international system, the hegemonic status of the United States is, to a great extent, rapidly fading, if it has not already completely faded. Emerging powers are becoming more assertive in expressing positions that are contrary to the interest of the United States, as exemplified by the current standstill in the United Nations with regard to the Syrian war. 
This research will rely on the balance of power theory ${ }^{9}$ and multilateralism as its theoretical and conceptual frameworks respectively. The balance of power is central to the realist's interpretation of the international system and is the most dominant theory in international relations in general (Wohlforth et al., 2007). According to Morgenthau (1985, p. 183), the balance of power is linked to the power-seeking nature of a state for the preservation or distortion of the status quo. He contended that the system attains "equilibrium" when there is stability. If the equilibrium is distorted by an "outside force" or by an actor or actors in the system, the system shows a tendency to re-establish either the original or a new equilibrium.

The aspiration of power on the part of several nations, each trying either to maintain or overthrow the status quo, leads of necessity to a configuration that is called the balance of power and to the policies that aim at preventing it. Morgenthau (1985, p. 183)

Morgenthau identified armaments and alliances as significant features of the balance of power. In order to have the capacity to either maintain or distort the distribution of power in global politics, states embark on amassing weapons and deploying military forces which trigger an arms race between them. This necessitates that military hardware gulps a large share of national budget. It also engenders fear, suspicion and security.

It is in recognition of situations such as these that, since the end of the Napoleonic wars, repeated attempts have been made to create a stable balance of power, if not to establish permanent peace, by means of the proportionate disarmament of competing nations. (Morgenthau, 1985, p. 196)

Alliances formation is an integral part of the balance of power in an international system that comprises many states. A state's decision to join or not join an alliance usually reflects "expediency" rather than "principle". A state will see no need for an alliance if the state has the capacity to effectively pursue its interests at the global level without the help of other states. Morgenthau argued:

Nations A and B, competing with each other, have three choices in order to maintain and improve their relative power positions. They can increase their own power, they can add to their own power the power of other nations, or they can withhold the power of other nations from the adversary. When they make the first choice, they embark upon an armaments race. When they choose the second and third alternatives, they pursue a policy of alliances. (Morgenthau, 1985, p.197)

Rosenau and Durfee (1995, p. 21) posited that the balance of power serves as a mechanism for the maintenance of stability in the international system. States behaviour is usually shaped by the structure of power (polarity) in the international system. "Although the functions of balance of

\footnotetext{
${ }^{9}$ In an anarchic international system, where states cannot always rely on the help of others for survival (self-help system), states embark on balancing against the most powerful state or coalition of states.
} 
power remains constant irrespective of the polarity of the international system, polarity does affect the actual implementation of the balance" (Rosenau \& Durfee, 1995, p. 23). The behavioural pattern is manifested through the system of balance of power. They argued that "the balance, law, war and diplomacy" are employed by actors to maintain the state system. Sometimes states lack the capacity to establish balance. Other times, they may see no logic in distorting the status quo. The balance of power influences the "behaviours" of states. Goldstein and Pevehouse (2008, p. 52) suggested that the "balance of power can refer to any ratio of power capabilities between states or alliances, or it can mean a relatively equal ratio". They equally see it as the rise of "counterbalancing coalitions" to challenge a state from becoming an empire. The counterbalancing is a constant feature of balance of power which guarantees the stability of the international system. "The system is stable in that its rules and principles stay the same: state sovereignty does not collapse into a universal empire” (, 2008, p.52).

Stability in the system does not symbolise peace; rather it is maintained by "recurring wars that adjust power relations" (Goldstein, 2008: 52). Goldstein and Pevehouse (2008) further argued that alliance formation is an important element of balance of power. A state deployment of military forces against the dominant state or competitor is one way of power balancing. However, alliance formation against the dominant states "is often quicker, cheaper and more effective" (Goldstein \& Pevehouse, 2008, p. 52). While some states may form an alliance to balance the strength of a threatening or powerful states (balancing), other states may "jump on the bandwagon of the most powerful state" (bandwagoning). They maintain that "in the anarchy of the international system, the most reliable brake on the power of one state is the power of other states" (Goldstein \& Pevehouse, 2008, p. 51). They further argued that:

\footnotetext{
In the post-Cold War era of US dominance, balance of power theory would predict closer relations among Russia, China, and even France - great powers that are not close US military allies. These predictions appear to be on the mark. Russian-Chinese relations have improved dramatically in such areas as arms trade and demilitarization of the border. France contested the US position vigorously in global trade negotiations and discussion of NATO's command structure, and sometimes sided with Russia and China in the UN Security Council, notably in 2003 before the Iraq War. (p. 52)
}

Stephen Waltz (2009) was of the opinion that two important factors make it essential for states to balance the most powerful state. Firstly, to ally with the dominant state connotes reliance on the state's continual "benevolence" which will ultimately pose a risk to the "survival" of the dependent state. Secondly, an alliance with the weaker side gives greater responsibility and 
"influence" to the new state, while alliance with the stronger side diminishes the new state's "influence" in global politics. Bull (1977) argued that while the theory of balance of power is assumed to emphasise the military capabilities of states, it recognises other sources of states' power. It is within this context that some scholars have identified soft balancing as a tactic utilised by states to counteract the dominant state in world politics. T.V. Paul belongs to this tradition of scholars. Paul (2005, p. 58) argued that hard balancing which is characterised by the arms race and alliance formation is insufficient to explain the current global politics. With the end of the cold war, states have resorted to "coalition formation and diplomatic bargaining within international institutions". This tactic, for him, is soft balancing.

... second-tier major powers - barring the United Kingdom - are concerned about the increasing unilateralism of the United States and its post-September 11 tendency to intervene militarily in sovereign states and forcibly change regimes that pursue anti-US policies (such as Iraq). In this new environment, the second-ranking states are taking steps - including bandwagoning, buck-passing, and free-riding - both to constrain US power and to maintain their security and influence. They have also begun to engage in "soft balancing," which involves the formation of limited diplomatic coalitions or ententes, especially at the United Nations, with the implicit threat of upgrading their alliances if the United States goes beyond its stated goals. (Paul, 2005, p. 47)

Pape (2005) argued that soft balancing employs non-military resources such as territorial denial, entangling diplomacy, economic strengthening and signals of resolve to weaken the influence of the dominant state. This implies that soft balancing entails an attempt to thwart the dominance of a superior state through the use of soft power currencies. Apparently, no state possesses the wherewithal to challenge the United States on the battlefield because of its military superiority.

Therefore states, particularly the BRIC states, have significantly employed their soft power resources to challenge the United States' global dominance through territorial denial, entangling diplomacy and economic strengthening. Specifically Russia, China and even Brazil have embarked on territorial denial to minimise the influence of the United States in their respective regions. Through entangling diplomacy, Russia and China have employed the veto power in the United Nations Security Council to frustrate the position of the United States illustrated by the Syrian crisis. They have also been promoting their distinctive world views in institutions such as the G20 and BRICS. The economic strength of the BRIC countries, evident in their growth rate and the resilience of their economies during the 2008 financial crisis, has impacted positively on their global influence vis-a-vis the relative decline of the United State. China's model of capitalism and authoritarian regime has gained more attention around the world and there have been predictions that China will overtake the United States as the largest economy in the near 
future. The resolve to balance is an attempt to resort into somewhat hard balancing which is evident in increases in the military expenditure of the BRIC countries in recent years.

The Bush administration post 9/11 unilateralist posture and the global financial crisis have changed the direction of global politics. The emerging and resurgent powers, China and Russia, with their economic and military muscles respectively, are in the position to distort the balance of power in their favour. It is within this context that the Syrian crisis that started in 2011 can be located. The vetoes of these Great Powers appear to be the factor that keeps the world at a standstill on an issue that requires urgent attention. China is the greatest threat to America's dominance in the globe among the emerging powers. John Mersheimer (2005) is of the opinion that if China continues to maintain steady economic growth over the next few decades, there is bound to be arms race between the United States and China which may eventually lead to war. Russia retains its potential as a major power owing to its possession of a nuclear arsenal and its control of a large amount of gas. The decline of the status of Russia, as a result of the collapse of the bipolar world order with its attendant unipolar international system, is still a tragedy that the Russian policy makers find difficult to erase from their memories (Turner, 2009). The formation of the BRICs signals a shift in international political economy. The BRICs, comprising the emerging economies, are exploiting the twin blows on the United States - global legitimacy that has plummeted and economic decline following America's unilateralism under Bush and the global financial crisis that began in the United States. The world is becoming increasingly multipolar with the emergence of China, India, Brazil, and with the resurgence of Russia (Renard, 2009). The European Union, despite its current financial crisis appears to have the wherewithal to have a significant impact on the emerging global politics.

Drawing inspiration from Ruggie, Bouchard and Peterson (2011, p. 10) have shown that most definitions of multilateralism take three factors into consideration: "rules", "inclusiveness" and "voluntary cooperation". They defined multilateralism as "three or more actors engaging in voluntary and (essentially) institutionalise international cooperation governed by norms and principles, with rules that apply (by and large) equally to all states". Multilateralism is the antithesis of unilateralism. In contrast to unilateralism, in which one state acts alone to take decisions of international consequence, multilateralism symbolises decisions or acts executed by more than two states. The driving force of multilateralism is the shared norms, beliefs and 
expectations by the members of the institution or regime. Ruggie (1992, p. 571) claimed that what distinguishes multilateralism from other "organisational forms" is the "principles" entrenched in a multilateral organisation. He defined multilateralism as "an institutional form which coordinates relations among three or more states on the basis of "generalised" principles of conduct - that is principles which specify appropriate conduct for a class of actions, without regard to the particularistic interests of the parties or the strategic exigencies that may exist in any specific occurrence". He argued that in the economic sphere, multilateral institution discourages discrimination among its members that produce similar goods and services. In the security realm, it ensures the prompt response to "aggression" without considering an individual state's interest. In general, multilateralism sacrifices an individual interest for collective good. It is a collective response to systemic problems. He further proposed two underlying tenets of multilateralism, "indivisibility" and "diffuse reciprocity". These tenets enable states to embrace collective long-term benefits in lieu of individual's short-term benefits. It is expected that there will be a measure of equity among members of a multilateral institution. It also entails collective security arrangement in which an attack on one is regarded as an attack on all. In Third try at world order, Ruggie (1994, p. 556) claimed that "a multilateral order embodies rules of conduct that are commonly applicable to countries, as opposed to discriminating among them, based on situational exigencies or particularistic preferences".

Multilateralism has the tendency to significantly boost a state's soft power. According to Nye (2004) foreign policies that are perceived by other states to be unilateral, arrogant, narrow and exclusive can erode a state's soft power. On the other hand, foreign policies that are perceived to be inclusive and multilateral, strengthen a state's soft power. The erosion of the United States' soft power and the attendant anti-Americanism, most especially in the Middle East, is attributed to the United States' unilateral war on terrorism in Iraq and the continual drone attacks in the Middle East. American soft power plummeted in Bush's era explaining why Obama embraced multilateralism, his diplomatic shuttles around the world and his reluctance to employ force in the pursuit of American foreign policy. According to Nau (2010, p. 27),

Under President Barrack Obama, US foreign policy has swung decisively in the opposite direction. Now, US security interests matter more than democracy, force is a last resort, substantial regulations are needed to end the booms and busts of global capitalism, and multilateralism is the sine qua non of US diplomacy. 
Economy, energy and the environment are the most important issues that encourage interdependence among states in the global arena (Grevi, 2009). Terrorism, climate change and nuclear proliferation are issues that cannot be handled by a sole state. These threats to global existence are addressed by a collective response. The 9/11 attacks on the United States attracted international condemnation and the United States benefitted massively from the huge support it received across the world particularly in its war on terrorism campaign in Afghanistan. In summary, the response to the event was multilateral. Thakur (2012) recognised international peace and security, economic development and international trade, human rights, functional and technical cooperation, and the protection of the environment and sustainability of resources are issues that cannot be left to the preserve of a single state. He argued that even the most powerful states cannot unilaterally solve these problems as a result of the interconnectedness of the globe. All states are vulnerable to the "dark side of globalisation" as the events of 9/11 have clearly shown. These issues he argued "require joint action to reduce costs and bring order and regularity to international relations" (Thakur, 2012, p. 1).

\subsection{Conclusion}

Polarity in the international system has stimulated debate among scholars and observers of international relations. A plethora of scholars have posited that the international system is unipolar because the United States has remained a dominant power in the international system and there are no challengers to contest the hegemony of the United States. Other scholars argued that the United States' decline and the rise of other players have led to the emergence of a multipolar system. Certain scholars have claimed that these traditional models are not adequate to explain the realities of the $21^{\text {st }}$ century global politics, and have therefore postulated alternative models that describe today's politics. The contribution of the researcher to this debate is the hybrid of Huntington's uni-multipolarity and Grevi's interpolarity.

Balance of power and multilateralism have provided adequate theoretical and conceptual frameworks for the themes of this research. There has been evidence of balance of power politics among the BRIC countries to counteract the global influence of the United States. Owing to the growing interdependence in today's world, states have resorted to multilateralism in their international relations. 
The next chapter of this research explores polarity in the twentieth century in order to contemplate $21^{\text {st }}$ century polarity using historical lessons. 


\section{CHAPTER THREE \\ The Twentieth Century World Order}

\subsection{Introduction}

The 'great powers' possess the strongest military arsenals and the largest economies which inform their prestigious status in global politics. In other words the great powers are the most powerful and important states in international politics owing to their economic and military might and formation of alliances is common (Sweeney \& Fritz, 2004, p. 428). This attitudinal tendency is particularly exhibited through balance of power. The aim of each great power is to distort the structure of global power in its favour. Each great power strives to be the most important state at the global arena. According to Mearsheimer:

There are no status quo powers in the international system, save for the occasional hegemon that wants to maintain its dominating position over potential rivals. Great powers are rarely content with the current distribution of power; on the contrary, they face a constant incentive to change it in their favour. They almost always have revisionist intentions, and they will use force to alter the balance of power if they think it can be done at a reasonable price. (2001, p. 2)

Aside from the military and economic endowment of the great powers, they also excel in other components of power such as in the advancement of technology, natural resources and quality population. This perhaps, informs why the great powers rarely relinquish their status in global politics. More often than not, great powers heavily defeated in war, retain their status as great powers. Germany and Japan were devastated by World War II. However, they retain their status as great powers today. Russia too is still regarded as a great power despite the disintegration of the Soviet Union (Goldstein \& Pevehouse, 2008).

The slow change in great power status is evident. Britain and France have been great powers for 500 years, Russia and Germany for more than 250 years, the United States and Japan for about 100 years, and China for 50 years. Only six other states were ever (but no longer are) considered great powers: Italy, Austria (Austria-Hungary), Spain, Turkey (the Ottoman Empire), Sweden and the Netherlands. (Goldstein \& Pevehouse, 2008, p. 55)

The number of great powers has fluctuated between two and five in more than 350 years of the modern international system. An international configuration of one dominant state is referred to as unipolar system. A structure with two power centres is generally called a bipolar system. When there are more than two dominant powers it is a multipolar system (Rosenau \& Durfee, 1995). The power configuration in international institutions usually reflects the dominance of the 
great powers in the international system. This was evident in the $19^{\text {th }}$ century concert of Europe and the modern day United Nations Security Council (Goldstein \& Pevehouse, 2008, p. 53). Against this backdrop, this chapter seeks to explore the power configuration of the twentieth century. In order to make sense of the structure of power in this century, the chapter explores the power politics of the nineteenth century. It further investigates the struggle for power in the multipolar and bipolar systems which culminated in the two world wars and cold war respectively in the twentieth century. The final substantive section of the chapter explores the unipolar era that resulted in the establishment of the United States as the sole superpower in the international system.

\subsection{The growth of multipolar order}

Prior to the $20^{\text {th }}$ century, all the great powers were confined to Europe. The dominant states in the $16^{\text {th }}$ century were Britain (England), France, Austria-Hungary, and Spain (Goldstein \& Pevehouse, 2008). The Ottoman Empire (Turkey) engaged in perpetual fights with the European powers, most particularly with Austria-Hungary. The House of Hapsburg was an empire which comprised Catholic countries of Spain, Austria-Hungary and Netherlands. These countries were defeated by the Protestant countries of France, Britain, Sweden and the independent Netherlands in the thirty years war between 1618 and 1648. The war engendered the signing of the Treaty of Westphalia which served as the basis for modern state's system (Goldstein \& Pevehouse, 2008). It was in the $18^{\text {th }}$ and $19^{\text {th }}$ centuries, that the multipolar order reached its peak. This framework determined international relations among European powers from the Treaty of Westphalia in 1648 through the mid-twentieth century. Between 1815 and 1914, the dominant powers were

Great Britain, France, Prussia/Germany, Austria-Hungary and Russia. Italy and the Ottoman Empire/ Turkey were also powerful in their own rights. The multipolar order was characterised by shifting alliances to prevent the emergence of a single power or coalition becoming so powerful as to dominate Europe and the world (Rourke, 2007).

In the $18^{\text {th }}$ century, Great Britain relied heavily on its powerful navy for its security. Its naval prowess provided it with the platform to sustain the most effective and efficient relations with its colonies despite the strong rivalries with Spain and France (Shennan, 1995). The French culture celebrated military assets. In this regard, France was the most potent military power and had secure borders and a unified land mass to its advantage. France gave priority to its military 
prowess in the pursuit of its interests through the display of its military superiority in Europe (Shennan, 1995). With respect to the Austrian Hapsburg Empire, paradoxically, the major elements of its power capabilities also served as sources of its susceptibility to rival states attacks. The empire was well endowed with both human and material resources. In addition, it prided itself with having a vast land mass. However, this enabled enemies to threaten and attack parts of its territories relatively easily (Shennan, 1995).

It was in the $18^{\text {th }}$ century that British power increased dramatically, following the industrial revolution. Britain's major competitor was France. While the power and by implication the influence of Sweden, the Netherlands and the Ottoman Empire plummeted in this period, Russia and Prussia (Germany) became major powers.

It is worth noting that the $19^{\text {th }}$ century marked the zenith of European expansion across the other continents. However, some empires such as Portugal, Spain and Netherland experienced decline (Woodruff, 1981). One would have expected that consequential wars would arise from the colonial struggle among the European powers. However, "the most decisive power struggles in the world in these years did not arise out of world colonization by the Europeans, but out of conflict within Europe" (Woodruff, 1981, p. 76). Remarkably, the singular event that significantly shaped international politics in the $19^{\text {th }}$ century and to a great extent still has meaningful relevance in today's world, was the French revolution of 1789. The revolution metamorphosed into a bloody war among the European powers. It commenced in 1792 between France on one hand, and Austria and Prussia on the other. Austria and Prussia had intervened to prevent revolutionaries from overthrowing King Louis XVI. However, the war dragged on until the defeat of Napoleon in 1815 (Woodruff, 1981). "In the Napeolonic wars (1803-1815), which followed the French revolution, France was defeated by a coalition of Britain, the Netherland, Austria-Hungary, Spain, Russia and Prussia" (Goldstein \& Pevehouse, 2008, p. 61). Britain was the most important player among these states. Therefore, it was only natural for it to act as the leader of the coalition. It could be argued that Britain was the power majorly responsible for the downfall of France in the war which ended with the Congress of Vienna (Woodruff, 1981, p. 78).

By the $20^{\text {th }}$ century, there was a shift of power concentration from Europe to other parts of the world. For instance the United States emerged as the world's largest economy. Japan and Italy 
also became major players in international politics. Structure of Power became globalised compared with the preceding centuries which were centred on the European powers. In the First World War, Germany, Austria and the Ottoman Empire (Turkey) were defeated by the allied forces of Britain, France, Russia, Italy and the United States (Goldstein \& Pevehouse, 2008, p. 62). In the Second World War; the axis powers - Germany, Italy and Japan - were defeated by the allied forces of the United States, Britain, France, Soviet Union (Russia) and China. Against this backdrop, the victors in the war could easily lay claim to permanent membership of the United Nations Security Council (Goldstein \& Pevehouse, 2008, p. 62).

\subsection{France, Britain and Europe in the nineteenth century}

Arguably, France was the most powerful state in the globe between $18^{\text {th }}$ and early $19^{\text {th }}$ centuries. With 21.5 million people, France was by far the most populous country in Europe in the $18^{\text {th }}$ century (Nye, 1990, p. 52). In terms of its economy, France enjoyed considerable wealth in this period. Even after France was defeated in 1815, it still accounted for 14.8 percent of Europe's Gross National Product (GNP) in 1830. With this figure, the size of France's economy narrowly outstripped the British which accounted for 14.2 percent (Nye, 1990, p. 52). France also prided itself on having the largest army in Europe which it could easily mobilise to project its power in the centre of world politics (Europe). Table 3.1 shows the size of the armies of the major powers in 1789 and $1812 / 1814$.

Table 3.1 ${ }^{10}$ : Size of armies (people)

\begin{tabular}{|l|l|l|}
\hline & 1789 & $1812 / 1814$ \\
\hline Britain & 40,000 & 250,000 \\
\hline France & 180,000 & 600,000 \\
\hline Habsburg Empire & 300,000 & 250,000 \\
\hline Prussia & 190,000 & 270,000 \\
\hline Russia & 300,000 & 500,000 \\
\hline
\end{tabular}

Source: Kennedy (1988)

\footnotetext{
${ }^{10}$ Table 3.1 clearly shows the dominance of France in the size of military personnel of the major powers in the nineteenth century.
} 
The years between 1789 and 1815 were characterised by turbulence in Europe. This was triggered by the French revolution and the Napoleonic wars. It was a total war - there was little differentiation between combatants and civilians as almost the entire population was mobilised for the belligerent effort. The civilians were either voluntarily enlisted in the army or provided other vital supports for the war effort. Against this backdrop, France penetrated the continent like a wild fire and the social, economic and political institutions of the European countries were completely altered. The eighteenth century that had been characterised by the European balance of power and mercantilism was changed by the French Revolution and was replaced by a liberal world order (Cox, 1987). Therefore, the French ideas of liberalism and nationalism provided the basis for the world's politics and ideology in the nineteenth century. Indeed, the European politics and, by extension, world politics between 1789 and 1917 were characterised by the struggle either for or against the ideas of the French revolution (Hobsbawn, 1962).

Since the Seven Years' war between 1756 and 1763, Britain had realised the necessity to prevent the emergence of an empire and subsequently embarked on the balance of power politics in Europe in its relations with other European countries and in Britain's pursuit of its commercial and imperial interests in other continents. However, Napoleon successfully distorted the balance of power in Europe and European countries became suzerains of France (Cox, 1987). Undoubtedly, Napoleon's imperial ambitions in Europe had the tendency to weaken the other great powers' influence and status. Therefore Great Britain, which was also a formidable great power, was threatened by the imperial ambition of France and therefore realised the urgency to restrain France from building an empire that stretched across the whole of Europe. To this end, France and Britain fought in seven major wars between 1689 and 1815 (Nye, 1990, p. 52). By 1814 Napoleon thought he had significantly thwarted the British economic edge by blocking British commercial access to Europe.

However, in that same year Britain financed armies of 150,000 in every prominent ally state and also financed British and mercenaries armies (225,000 soldiers) from other great powers (Cox, 1987, p. 119). In addition, throughout the period, the British exports skyrocketed. Between 1794 and 1796, Britain's exports totalled 21.7 million pounds. The total was 37.5 million pounds from 1804 to 1806 and 44.4 million pounds between 1814 and 1816 (Kennedy, 1988, p. 130). However, this does not necessarily imply that the British economy was not affected by 
Napoleon's blockage of England's trade. Most especially in 1808 and between 1811 and 1812, the ban cumulated in an economic crisis in British trade as a huge number of manufactured products had to remain in warehouses in England. Nevertheless, the British economy was resilient owing to the rise of trade between Britain and regions outside Europe such as America, Asia, Latin America, Africa and the West Indies coupled with the waxing industrial revolution in England (Kennedy, 1988). Table 3.2 below shows Britain's wartime expenditure and revenue between mid-eighteenth and early nineteenth centuries.

Table 3.2: British wartime expenditure and revenue (pounds)

\begin{tabular}{|l|l|l|l|}
\hline Inclusive years & Total expenditure & Total income & $\begin{array}{l}\text { Balance raised by } \\
\text { loans }\end{array}$ \\
\hline $1756-63$ & $160,573,366$ & $100,555,123$ & $60,018,243$ \\
\hline $1776-83$ & $236,462,689$ & $141,902,620$ & $94,560,069$ \\
\hline $1793-1815$ & $1,657,854,518$ & $1,217,556,439$ & $440,298,079$ \\
\hline
\end{tabular}

Source: Kennedy (1988)

The implication of these figures was that Britain had enormous resources to finance the war effort and did not hesitate to raise loans to achieve its objectives. Despite the fact that the GNP in France surpassed that of Britain in this period, Britain had better public finance management and was able to manage the national debt arising from the war efforts better than France. This British attribute turned out to be a major downfall for France during the war. The French financial operations were ridiculously decentralised. The municipal governments, the clergy, provincial estates and tax farmers were all involved in revenue collection. The system was riddled with high levels of corruption as most taxes were embezzled by these officials (Kennedy, 1988).

The eventual defeat of France in 1815 at Waterloo was achieved by a Grand Alliance spearheaded by the mercantile Britain (Hobsbawn, 1962). Other states in the alliance included absolute monarchies of Russia, Prussia and Austria (Cox, 1987). The victory of the alliance was achieved largely because of the British dominance in sea power and Russia's massive territory and manpower (Cox, 1987). Following the defeat, France ceased to be the dominant power in Europe and it was occupied by foreign troops. The defeat also galvanised the coalition forces 
with the motive to restore the European state system status quo - the European state system prior to the French revolution and Napoleonic wars.

After Napoleon's domination of Europe from around 1800 to 1814, the other states realised the moral imperative to mitigate the recurrence of such a bitter experience. It was against this background that representatives from all the great powers met at the Congress of Vienna to discuss and negotiate a new balance of power in Europe with the primary objective of preventing an empire capable of dominating Europe (Ketelbey, 1929). The four great powers - Austria, Great Britain, Prussia and Russia - convened the Congress of Vienna in 1815 to determine the nature of the European balance of power. Schroeder (1992) observed that while there has been divergent scholarly explanation of what constituted the Vienna settlement, there is wide consensus on the influence of a system of balance of power in the 1815 settlement. This frame of mind was reflected in virtually every document of the peace makers such as treaties, letters and diaries. There was emphasis on peace and stability through the redistribution of territories and people. However, there was no agreement on what the balance of power would entail as reflected in the great powers' different interpretations of this. It is interesting, and worth an extensive quotation, that the positions of different powers were diverse:

For Britain, a balance of power implied a state system, a series of frontiers and stable alignments
containing France within her historic frontiers. To the Austrians it meant a state system and frontiers
which gave her predominance in Central Europe and security against a Russia seeking to encroach on
Poland and the Ottoman Empire and to extend her dynastic influence in the German courts. The
danger of a French hegemony in Europe was for them a lesser evil and in any case they could count
upon Great Britain to keep France within bounds. Similarly Great Britain looked to Austria and
Prussia to check Russia, whose expansion was, in British eyes, a lesser evil than the strengthening of
the French imperial base in Europe. As for Russia, her conception of a balance of power was of a quite
different order: as a spasmodically expansionist power she regarded a balance of power as something
to be manipulated to facilitate the fulfillment of her designs. (Dakin, 1979, p. 15)

The 1814 Peace of Paris led to the disintegration of the French Empire leaving France with its 1792 territorial borders. With the successful restoration of the European state system at Vienna, the second Peace of Paris was signed in 1815. This accord was even more severe regarding French interests and France considered it unprecedented (Bullen, 1979) and strongly opposed the allied powers (England, Austria, Russia and Prussia). France identified three major grievances responsible for their opposition - firstly, the allied powers benefited from France's defeat through their territorial aggrandisement which was vitally detrimental to French interests. Secondly, France claimed that there was a deliberate action to downgrade France from being a 
great power which manifested in reducing France's sphere of influence and surrounding it with belligerent and powerful states. Finally, the 1815 treaty was perceived as a legal mechanism to establish a strong league against France and to distort its influence in Europe (Bullen, 1979, pp. 124-125). French power was not significantly eroded despite the 1815 defeat. France remained one of the leading states in Europe (Kennedy, 1988). Even though the defeat of Napoleon was decisive, his influence on European politics cannot be over-emphasised.

Liberalism was transported to other European states particularly in Western and Central Europe. Similarly, East and Central Europe embraced the French idea of nationalism. Unlike the other great powers, France combined both a large standing army and a strong navy. Even though the Russian army was larger, French soldiers had better training and had access to more sophisticated arsenals. The British navy was second to none in the continent, not only in terms of its size, but also in terms of its quality and sophistication. However, the uniqueness of the French military capabilities lay in its ability to effectively combine naval and land forces. Despite its defeat, France remained stronger than Prussia and Russia (Bullen, 1979).

In the years after the congress of Vienna the leaders of the other powers never doubted that France had a considerable potential for disrupting the new international order. From 1817 onward, with the creation of the Quintuple Alliance, France was treated as an equal by the victorious allies; this was a matter of necessity not of courtesy. (p. 129)

It goes without saying that Britain was the main benefactor of the fall of France. In the eighteenth century, the major source of Britain's power was its navy. In this realm, Britain had no rival. It also had advantage over France in it solid management of public finance which was crucial to mobilising funds for its military activities (Nye, 1990). In the nineteenth century, Britain acquired more sources of power: firstly, in an exponential increase in its population from 10 million in the eighteenth century to 40 million in the nineteenth century, and secondly, from a rapidly growing industrial sector. In 1800, the industrial production in France and Britain was almost the same. In the 1850s Britain had surpassed France as the largest producer of manufacturing goods in Europe (Nye, 1990, p. 52). With these advantages, Britain was the dominant power in the international system. Table 3 below shows Britain's share and rank in the world's manufacturing production over approximately two centuries. 
Table 3.3: Britain's share of world manufacturing production, 1800-1980

\begin{tabular}{|l|l|l|l|l|l|l|l|l|l|}
\hline Year & 1800 & 1830 & 1860 & 1880 & 1900 & 1913 & 1939 & 1953 & 1980 \\
\hline Share & $4.3 \%$ & $9.5 \%$ & $19.9 \%$ & $22.9 \%$ & $18.5 \%$ & $13.6 \%$ & $10.7 \%$ & $8.6 \%$ & $4.1 \%$ \\
\hline Rank & $2^{\text {nd }}$ & 2 nd & $1^{\text {st }}$ & 1 st & 2 nd & 3 rd & 3 rd & $3^{\text {rd }}$ & 6 th \\
\hline
\end{tabular}

Source: Nye (1990)

Still adhering to its balance of power politics in Europe, Britain endeavoured to fortify Prussia and Austria to balance the power of France and Russia, and also strived to have close alliance with the smaller states in Europe and prevent the control of these states by other great powers (Cox, 1987). Between 1815 and 1870, Britain rose to pre-eminence owing to the stability in the international system as there was no challenger to distort the balance of power which was clearly in favour of Britain. Cox (1987) argued that the capacity of Britain to sustain its balance of power policy in Europe transformed into British global dominance of power as its trade extended extensively to Europe, South America and the United States rather than its colonial states. This era of Britain's pre-eminence was characterised by, firstly a more integrated world economy centred on the British economy and secondly, stability in the international system. However, there were wars associated with the great powers' imperial expansion. Thirdly, the development of technology had a remarkable impact on military and naval warfare. Railways, telegraphs, quick firing guns, steam propulsion and armoured vehicles emerged as important indicators of the great powers' military capacity (Kennedy, 1988).

Nye (1990) argued that, contrary to the description of this era as Pax Britannica Britain did not completely dominate all the major sources of power. Britain ranked second in the number of armies after the Napoleonic wars and fourth towards the First World War. In terms of its share of global GNP, Britain occupied the third position behind Russia and France in 1830 and maintained the same position behind Russia and Germany in 1913. Britain only dominated the production of manufactured goods between the $1860 \mathrm{~s}$ and $1880 \mathrm{~s}$ and lost its position to the United States by 1890 and was also surpassed by Germany in the early twentieth century (Nye, 1990, p. 54).

However, one area in which Britain enjoyed superiority was its share of global trade. Owing to its imperial activities, Britain enjoyed this privilege until the Second World War (Nye, 1990). 
Given these realities and the spread of industrialisation to other parts of Europe and beyond, Britain began to decline as other countries' influence rose. The influence of Britain within Europe declined following the rise of Germany which had massively benefitted from the spread of industrialisation. Germany's rise was significantly marked by its victories in limited wars against Austria in 1866 and France in 1870 (Cox, 1987). Between 1870 and 1890 Europe was characterised by the alliance formation of the great powers and by the 1890s, Europe had been polarised by two alliances: firstly, an alliance of Germany, Austria and Italy, and secondly, an alliance of France and Russia which was later joined by Britain (Cox, 1987). Outside Europe, the United States and Japan also benefitted from the relative decline of France and Britain. These countries became more assertive in their respective regions, thereby distorting the balance of power which had hitherto favoured Britain. These countries were so powerful to the extent that Britain had to make concessionary arrangements with them regarding its naval jurisdiction (Nye, 1990).

Thus, Britain signed an alliance with Japan and appeased the United States with conciliatory measures, including accession to the Panama Canal, which further enhanced America naval strength by allowing the United States to shift its fleet quickly between two oceans. Henceforth, Britain applied the traditional two-power naval standard - that is, a navy equal to the next two contenders - only to its home waters. (pp. 58-59)

\subsection{The First World War}

The First World War was a major war between all the great powers and numerous minor powers in Europe. Specifically, all the European states except Spain, the Netherlands, Switzerland and the Scandinavian countries participated in the war (Hobsbawn, 1994). The war distorted the long period of peace that had existed in Europe since 1815, during which time there was no war involving all the great powers. From 1871, no two European great powers fought each other in a war. However, the great powers often fought weak states within and outside Europe. Sometimes, the major powers downplayed the resistance from the weak states which sometimes turned out to be frustrating such as the Boer war (Hobsbawn, 1987). However, World War I changed this tradition as the participants aggressively mobilised their human and material resources to fight a total war. One of the major significances of the War was its impact on contemporary international politics as it was followed by fundamental changes in international politics. 
The war began with the assassination of the Austrian heir apparent, Archduke Franz Ferdinand, by the Serbian nationalists. Following this incident, Austria was determined to fight Serbia, a nation which was part of the Austrian empire but which had always agitated for the rights of nations to self determination. Austria's confidence was strengthened with the assurance of German support in the event of Russia's intervention in the war. Therefore, on July 28, 1914, Austria declared war on Serbia and in August of the same year, France, Great Britain and Russia formed an alliance against Germany and Austria-Hungary. In the course of the war, the allied powers attracted states like Japan, Italy and the United States. Bulgaria and Turkey joined the German and Austria-Hungarian side (Ray, 1979).

The war, which was initially confined to the European states specifically the "triple alliance" of France, Britain and Russia and the central powers of Germany and Austria-Hungary, soon attracted other states such as Turkey and Bulgaria which allied themselves with the central powers. Italy, Greece, Romania, Portugal and Japan joined the triple alliance. Japan primarily joined the war to protect its geo-political interests in the Far East and Western Pacific. The decisive moment of the war was in 1917 when the United States finally decided to join the Allied forces (Hobsbawn, 1994). The involvement of overseas troops to fight in a region different from their own was unprecedented: Canadian troops were in France, American military men were in Europe, Indian troops were visible in Europe and the Middle East, the Chinese were also involved and Africans were recruited in the French army (Hobsbawn, 1994).

As the most important power among the central powers, Germany glorified itself in its sophisticated military equipment, solid organisation and a strategically reliable railway system which ensured an easy and expeditious mobilisation of troops. But as the war dragged on, the allied forces had better military resources and more military personnel. They relied heavily on their command of the sea which was strategic for the mobilisation of resources. However, they were constrained by factors such as lack of consensus, apathy among some states and the remoteness of Russia from other allied states (Ketelbey, 1929). In the twilight of 1914, the allied powers' naval capability was superior to the central powers. While German international trade was largely constrained by its lack of adequate access to the sea, Britain still enjoyed uninterrupted international trade despite German policy of unrestricted submarine warfare. In 
reaction to Britain's blockade of German coasts, Germany declared a war zone on British islands.

The implication was that the ships of the hostile countries on the islands would be sunk. The United States vigorously contested the legality of this policy on the basis of its consistency with international law ${ }^{11}$. Against this background, the United States asserted that Germany would be held responsible for any American loss of lives and sunk ships. In defiance of the United States warning, Germany was responsible for the sinking of American ships and loss of numerous American lives between 1915 and 1917. In January 1917 Germany declared that "all ships, neutral or belligerent, found within the warzone would be sunk at sight" (Ketelbey, 1929, p. 429). Following this incident, America broke diplomatic relations with Germany and finally declared war against Germany on April 6, 1917. Other countries such as China, Greece and Siam also joined the allied powers in the same year. At that point, it appeared the entire world was against Germany. Victory of the allied powers seemed assured. German allies began to surrender one by one.

In September Bulgaria surrendered, and from the end of October 31 Turkey submitted unconditionally, on November 4 Austria-Hungary followed on the same terms. Germany was left alone. She could do no other than ask for terms. On November 11 an armistice was signed between the belligerent leaders, and from eleven 0' clock on that memorable day firing ceased over the western front. (Ketelbey, 1929, p. 428)

The underlying cause for the war requires careful consideration. It is quite unimaginable that a conflict between Serbia and the rapidly declining Austria-Hungary could lead to a full-blown world war involving all the great powers. Ray (1979) identified several factors responsible for the war: firstly, the alliance formation prior to the war. While Germany had an alliance with Austria-Hungary, Russia was not allied with Serbia. Its immediate intervention was intended to defend Serbian nationalism and also prevent dominance of Austria-Hungary in a territory which Russia envisaged would be a viable access route to the sea. Russia was aligned with France and England. In this light, the immediate support the Russians garnered from France did not come as a surprise to Germany. They were convinced that they were adequately prepared for possible French intervention. In this light, the nature and escalation of the war could be argued to reflect the alliance system of the great powers in the period. Secondly, the sophisticated military

\footnotetext{
${ }^{11}$ International law stipulates that there must be prior warning before a ship is sunk and the lives of passengers must be protected.
} 
arsenals and the orientation of the military officers, had a role to play Generals in this period strongly believed that aggressive mobilisation of forces would determine the winner of the next war. This informed why, to a great degree, Germany and Russia and, to a lesser degree, AustriaHungary and France consciously formulated policies to ensure rapid mobilisation. Other factors identified by Ray (1979) included German militarism, nationalism, the European countries' press and European arms races particularly the naval arm race between Germany and Britain.

In the wake of 1919, the victorious bloc met to deliberate the terms of peace. While thirty two nations had representatives, the central powers along with their allies and Russia ${ }^{12}$ were not invited. To a large extent, the "big four" - United States, France, Great Britain and Italy dominated proceedings at the conference (Ketelbey, 1929, p. 439). The United States President, Woodrow Wilson's January 8, 1918 speech to the congress laid out fourteen points for the terms of peace and the creation of the League of Nations. The fourteen points include:

Open covenants of peace and transparent diplomacy, absolute freedom of the seas, the removal of economic and trade barriers, an end to arms races, national self determination to figure in adjustment of colonial claims, evacuation of all Russian territory, evacuation and restoration of Belgium, all French territory restored, Italian frontiers adjusted, Austria-Hungary given "opportunity to autonomous development, Romania, Serbia, Montenegro evacuated and given independence, Turkish portion of the Ottoman Empire should become sovereign; nations under Turkish rule should become autonomous, Dardanelles should be open to all, independent Poland with access to the sea should be created, a general association of nations should be formed to guarantee political independence and territorial integrity to great and small states alike. (US foreign policy)

The fourteen points served as the basis for the Versailles Peace Conference. However, both the victorious powers and enemy powers were dissatisfied with the Versailles Peace. Germany helplessly experienced international ignominy as there was drastic reduction in its army and the production of arms, its air force was obliterated, the use of submarine was prohibited and its colonies were seized. It was hoped that these measures would prevent Germany from threatening the peace of Europe. However, Germany was expectedly dissatisfied with the peace settlement as it was practically reduced to a state with little or no influence in the global arena. France was also disappointed with the treaty because Paris had hoped to use the medium provided by the Paris Conference to annihilate Germany. Some of its demands such as Rhineland buffer state were ignored. Japan and China were also dissatisfied with the treaty because their territorial interests were not sufficiently taken into consideration (Woodruff, 1981).

\footnotetext{
${ }^{12}$ Russia was denied invitation following the Bolshevik Revolution of 1917 which established socialism in the country.
} 
One of the significant effects of the First World War was the decline of European powers and the rise of the United States as the most important power. Prior to the First World War, international politics was Euro-centred. All the major powers were European states. After the war, the European great powers were devastated and the resultant effect was the ascendance of the United States as the most powerful state. In fact, the 1917 United States entry into the First World War was the most decisive turning point (Ray, 1979). Following the war, America began to dominate the global economy. Britain, France and Germany depended on Washington's economy.

\subsection{The Second World War}

The victor powers desperately searched for the kind of peace settlement which would make impossible another war like the one that had just devastated the world, and whose after-effects were all around them. They failed in the most spectacular manner. Within twenty years the world was once again at war .(Hobsbawn, 1994, p. 32).

Hobsbawn (1994) observed that scholarly literature on the origins of the Second World War is rare, similar to the First World War. For him, this reflects the consensus among scholars on the aggressors in the war - Germany, Japan and Italy. He claimed that "in the simplest terms the question who or what caused the Second World War can be answered in two words: Adolf Hitler" It is also within this context that Calvocoressi, Wint \& Pritchard (1972) argued that scholarly explanation of the origins of the war can be divided into two schools. The first perspective posits that the war was solely caused by Adolf Hitler. The other perspective argues that the war manifested because Adolf Hitler and other people saw the need for the war in order to achieve the same objectives. However, some scholars have disagreed with these positions for their simplicity. They argued that it would be erroneous to attribute a war of such magnitude to a single individual. The war had very complex origins and it would be misleading to ascribe the cause to a man, a country or a continent: "The conflict of 1939-45 was a world war and not one man's war" (Calvocoressi, Wint, \& Pritchard, 1972, p. 17). This, however, does not imply that they downplay Hitler's aggressive nature and his major contribution to the war. They argued:

But it does not follow that Hitler was a man or a politician like any other. He was not. On the contrary, he was decidedly outside the normal run of men and of statemen, and the other things that made him different contributed to the war. He saw human affairs as a conflict; he portrayed this conflict as a moral one in which he had a role which justified every means; yet normally speaking he was, by any ordinary standards, himself a criminal who used murder openly and massively. Such beliefs and such behavior cannot fail, if allied with power, to promote war. (p. 17) 
It must be noted that the world order after World War I left some disputes unsettled. It was therefore not surprising that the period between the First and Second World Wars was characterised with instability and tensions which ultimately triggered World War II. Discontent with the post World War I order was not only expressed by the defeated states such as Germany but the victorious states like Japan and Italy were also dissatisfied with the Versailles Treaty. Even though Italy benefitted from the war greatly in terms of territorial acquisition such as in the Alps, the Adriatic and in the Aegean Sea, Italy was dissatisfied with the emergence of fascism in the country with its inherent nationalistic and imperialist tendencies. Japan's discontent was reflected in its desire to promote its economic interests in the Far East and it saw the West, particularly the United States, as a threat to this (Hobsbawn, 1994, pp. 36-37).

Arguably, the international political arrangement of the Versailles Treaty might have created tensions, but the immediate cause of the war reflected the aggression of the Axis Powers Germany, Japan and Italy. Hobsbawn observed:

The milestones on the road to war were the Japanese invasion of Manchuria in 1931; the Italian invasion of Ethiopia in 1935; the German and Italian intervention in the Spanish civil war of 1936-39; the German invasion of Austria in early 1938; the German crippling of Czechoslovakia in March 1939 (followed by the Italian occupation of Albania); and the German demands of Poland which actually led to the outbreak of war. (1994, p. 37)

On 1 September 1939 Germany embarked on the invasion of Poland. This event signaled the beginning of the Second World War. In a short time Germany conquered Denmark, Norway, the Netherlands, Belgium and France. Between July and September, Germany could not, however, win the air battle against Great Britain. Therefore, Great Britain was the only country at war with Germany as it was absolutely adamant that it would not accept Adolf Hitler's terms (Hobsbawn, 1994). Following the German success story, Italy, which had remained neutral decided to ally with Germany. With the German success, the war appeared to be over Hobsbawn (1994). Despite Germany's inability to successfully invade Britain owing to the formidable British air and sea capabilities, "there was no foreseeable war in which Britain could return to the continent, let alone defeat Germany" (Hobsbawn, 1994, p. 39). However, with the 22 June 1941 German invasion of Russia, there were renewed fierce battles. By the end of 1941, the war was being fought on three fronts - in the USSR; in the west fought by the Royal Air Force in Britain; and, the Mediterranean contest for North Africa and Middle East between Germany and Italy on one hand, and Great Britain on the other. The war that began as a European war in 1939 
metamorphosed into a global war as the Japanese wars which began prior and during the war the 1937 Sino-Japanese war and the 1941 American-Japanese war became integral parts of the Second World War (Hobsbawn, 1994).

One of the most interesting and influential developments in the war was the rivalry between Germany, on one hand, and Britain and France on the other, over alliance with the Soviet Union. Britain and France had earlier guaranteed Poland their support in the event of German aggression against Poland. The western powers had realised that an alliance with the Soviet Union would be vital for them to uphold their commitments to Poland. However, in August 1939, Russia signed a treaty with Germany. It was in the realisation of the strategic importance of Russia in its planned attack on Poland that Germany moved to sign the treaty with Russia. Hitler had calculated that if he could garner the alliance of Russia, the possibility of France and Britain waging war against Germany might be reduced.

Despite fighting so hard to ensure the pact with Russia was signed, Hitler knew he would violate it eventually (Ray, 1979, p. 21). The reason for the pact was specifically to deter Great Britain and France from waging war against Germany over its invasion of Poland. Stalin's decision to sign a pact with Germany rather than the Western powers stemmed from his belief that the Western powers might not adhere to their commitments in the event of a German attack on Russia. He was certain the western powers wanted the downfall of communism. Stalin had hoped that the pact would keep Russia out of war and was therefore dumbfounded in June 1941 when Germany attacked Russia. "It is possible that what surprised Stalin was the timing of the attack rather than its occurrence" (Ray, 1979, p. 21). The German attack on Russia turned out to be a disaster as Russia was resilient and was able to resist the German army until the Russian winter finally crushed the German forces. While Germany was struggling with the war in Russia, Japan attacked the Pearl Harbour. While it could be argued that Japan underestimated the military capability of the United States, Japan is unlikely to have believed it could defeat the United States in an all out war. Rather, Japan's plan was to resist a United States retaliatory attack to the point of frustrating the US into allowing Japan to promote its economic interests in China, South East Asia and Indonesia, which the US had thus far prevented. 
As it turned out, "the decisions to invade Russia and to declare war against the United States decided the result of the Second World War" (Hobsbawn, 1994, p. 41). However, the war did not immediately cease with the entry of the United States which was triggered by the Pearl Harbour attack by Japan. Japan did not desist from its conquest of South-East Asia and Germany was still fighting the battle in Russia, particularly in Moscow and Alexandria. It was the victory recorded between 1942 and 1943 by the Allied forces in Stalingrad, El Alamein and in the Pacific that changed the direction of the war (Woodruff, 1981). Finally in 1945, the Allied Forces recorded a massive victory that ended the war. Woodruff observed:

On 13 February 1945 the greatest single slaughter in the history of European warfare took place. In 14 hours Dresden, 'the Florence on the Elbe', and 135,000 of its citizens were incinerated by British and American air bombardment. The German attempt to recover the initiative in the West by striking through the Ardennes in the Autumn of 1944 failed, as most German commanders had expected it would. (1981, p. 209)

Following this incident, Adolf Hitler committed suicide on 30 April 1945. Italian Benito Mussolini was assassinated by Partisans on 28 April 1945. With these developments, Germany had no other alternative but to surrender unconditionally which signalled the end of the World War (Woodruff, 1980). Japan also recorded heavy losses in 1945. The United States, heavily supported by Britain, launched massive attacks in Japan. On 23 May, an American attack on Japan resulted in 83,000 deaths and on 6 and 9 August, the United States dropped atomic bombs on Hiroshima and Nagaski. "In Hiroshima alone, 78,000 people were killed instantly, 100,000 were injured, 200,000 were left homeless" (Woodruff, 1981, p. 210). In this light, the remaining axis power in the war also had to surrender unconditionally on 2 September 1945.

Perhaps the most significant effect of the war was the emergence of the United States and USSR as the super powers of the international system and international politics during the next few decades reflected the interaction between these two powers. However, these countries had shown potential for super power status prior to the war. In 1938, the population of each of the states at least doubled those of the other great powers. The United States was the dominant industrial power and the Soviet Union had leapfrogged France and was closely behind Britain in terms of its share of production of manufactured goods (Nye, 1990, p. 69). The other great powers that participated in the Second World War were largely decimated and destroyed by the war to the extent that they could no longer lay claim their status in the international arena prior to the war. 


\subsection{The cold war and the bipolar order}

An important feature of the twentieth century was the rivalry among the great powers for global dominance. As was evident in the two world wars, the great powers battled to attain global hegemony. It was within the same frame of mind that the two super powers - United States and USSR - of the cold war engaged in a competition for global dominance (McGrew, 1992). The two super powers each had ideological missions, spheres of influence and massive nuclear weapons. International relations in this period reflected the interactions between the two super powers as the United States and USSR strove to spread the gospel of capitalism and communism respectively. The relationship between the super powers, as one would expect, engendered arms race as each super power endeavoured to outwit the other in military superiority. The consequence of this was a perpetual security dilemma - the action of one's superpower to guarantee its own security such as deploying military arsenals created fear in the other super power. "The logic of bipolarity was itself a logic of insecurity, according to which the actions taken by one side to enhance its security could also too easily be seen as a threat to the interests of the other" (Lewis, 1992, p. 36).

The origin of the cold war is a subject of controversy among scholars, political analysts and keen observers. Against this background, Dunbabin (1994) categorised scholarly analysis of the cold war into three approaches. Firstly, the cold war appeared to be a natural outcome of the Second World War which created a power vacuum following the devastation of Germany, Japan and Europe, most especially the British Empire. The situation engendered the emergence of two superpowers with distinctive ideologies to spread around the globe. Secondly, the expansionist policies of Joseph Stalin during the Second World War and in the post-world war period had a big effect. Dunbabin (1994) argued that if the United States had endeavoured to contain Stalin in the immediate post-war period, he would have possibly reconsidered his expansionist policies. Thirdly, the expansionist character of the United States needs to be taken into account as became evident in its sole control of Japan and its exclusion of USSR from Italy.

It goes without saying that the United States and USSR emerged as the dominant states in 1945. It must however be noted that the Soviet Union could exercise such decisiveness and influence in the immediate post-war period simply because the United States did not see the need to challenge the communist power. The United States emerged from the war as undoubtedly the most powerful state. In addition, it emerged as the only nuclear power state. Its economy was 
second to none and it prided itself in highly sophisticated land, sea and air forces (Woodruff, 1981). In 1943, the United States manufacturing of arms and ammunitions tripled that of any of Germany, Britain and the Soviet Union. The United States' GNP increased massively (by 50\%) during the war, the Western European countries' economies were heavily battered and the economic growth of the Soviet Union suffered for about ten years (Nye, 1990). By 1950, the United States' economy tripled that of the Soviet Union, was five times stronger than Britain's and ten times stronger than Japan's (Nye, 1990, p. 70).

Another major source of American power was its soft power currency which manifested largely in its ideological appeal. The ideology of liberalism-capitalism in the economic sphere and democracy in the political realm served as an American symbol throughout the period of the cold war. This ideology was appealing to many countries in Western Europe, some parts of Asia, America and Africa and it served as the driving force for America to spread its sphere of influence across the globe. The United States Marshall plan "provided the incentive to join the new economic order" (Cox, 1987, p. 215). In other words, Western Europe, ravaged by the war, had no alternative to the United States capitalist system owing to the Marshall plan offered to them by America to recover from their economic challenges. Table 3.4 below indicates the total Gross National Product (GNP) and per capita Gross National Product of the major powers in 1950. The table clearly shows that the United States had by far the largest economy. At $\$ 381$ billion, America's economy tripled that of its closest rival - the Soviet Union - which recorded $\$ 126$ billion as its GNP. The third largest economy (the United Kingdom) accounted for \$71 billion. This clearly depicts that the United States was in a class of its own in terms of its share of the global economy in this period.

Table 3.4: Total GNP and per capita GNP of the powers in 1950 (in 1964 US dollars)

\begin{tabular}{|l|l|l|}
\hline Country & Total GNP & Per capita GNP \\
\hline United States & 381 billion & 2,536 \\
\hline USSR & 126 billion & 699 \\
\hline UK & 71 billion & $1,393(1951)$ \\
\hline France & 50 billion & 1,172 \\
\hline West Germany & 48 billion & 1,001 \\
\hline Japan & 32 billion & 382 \\
\hline Italy & 29 billion & $626(1951)$ \\
\hline
\end{tabular}

Source: Kennedy (1988) 
The Soviet Union, on the other hand, relied on three major sources of power - military, geography and soft power. Its strategic location in Eurasia enabled the super power to wield influence in Europe, China and Japan. Its major source of soft power was its communist ideology which appealled to some states in Eurasia and beyond (Nye, 1990). In Africa, states like Angola (under MPLA) were attracted to the Soviet communist system. In the Americas and Caribbean, Cuba found communism appealing and in Asia, China also embraced socialism. However, the Soviet impressive soft power was undercut by its heavy reliance on its hard power in the pursuit of its global interests (Khanna, 2009).

In addition, it enjoyed the largest territory and possessed the third largest population in the world. In the realm of economy, it was the largest economy almost throughout the cold war and prided itself in production of major natural resources such as oil, gas and gold and, in fact, its production of oil and gas outweighed that of Saudi Arabia (Nye, 1990, p. 116). Its military force was massive and no doubt it accounted for the largest armed forces coupled with its huge nuclear arsenal amounting to almost half of the world's total during the cold war. It goes without saying that one of the most important features of the cold war was the arm race between the two blocs. Table 3.5 shows the military expenditure of some of the major powers between 1965 and 1970 . What is most noticeable in these figures is the closeness of the United States and USSR military budget in every year under review.

Table 3.5: Defence Expenditures of some of the great powers (billions of dollars)

\begin{tabular}{|l|l|l|l|l|l|}
\hline Date & US & USSR & $\begin{array}{l}\text { West } \\
\text { Germany }\end{array}$ & France & UK \\
\hline 1965 & 51.8 & 62.3 & 5.0 & 5.1 & 5.8 \\
\hline 1966 & 67.5 & 69.7 & 5.0 & 5.4 & 6.0 \\
\hline 1967 & 75.4 & 80.9 & 5.3 & 5.8 & 6.3 \\
\hline 1968 & 80.7 & 85.4 & 4.8 & 5.8 & 5.6 \\
\hline 1969 & 81.4 & 89.8 & 5.3 & 5.7 & 5.4 \\
\hline 1970 & 77.8 & 72.0 & 6.1 & 5.9 & 5.8 \\
\hline
\end{tabular}

Source: Kennedy (1988) 
Between 1945 and 1947, East-West relations were aggravated amidst political developments in Europe. Communism had spread like wild fire in Eastern Europe. By 1948, Eastern Europe had come under the control of the Soviet Union. The only exceptions were Greece, Turkey and Yugoslavia. Communism was adopted in Poland, East Germany, the Baltic States (except Finland), Romania, Yugoslavia, Hungary, Bulgaria, Albania and Czechoslovakia (Woodruff, 1981). On the other hand, the United States provided aid - Marshall Aid - for the reconstruction of the West which had been ravaged and devastated by the Second World War. The United States and USSR were allied to Western and Eastern Europe respectively. Of major concern, however, were Germany and Austria, states which had been jointly occupied by the USSR, USA, UK and France. In 1948, the western allies created the West German State and it became a member of NATO in 1955. East Germany (the German Democratic Republic) was an ally of the USSR and had communist regime (Dunbabin, 1994).

The hope of world peace that characterised the idealistic principles upon which the United Nations was founded had to succumb to the power politics of the cold war. Following ineptitude on the part of Britain to protect Greece and Turkey against a communist incursion, the United States, under the leadership of Harry Truman, embarked on the policy of containment - a policy specifically designed to prevent the spread of communism across the globe. With the 1949 signing of the North Atlantic treaty by the United States, ten European countries and Canada in 1949, the North Atlantic Treaty Organisation (NATO) was formed. In response, the Soviet Union formed the Eastern Security Treaty (Warsaw Pact) in 1955 (Woodruff, 1981).

Malaya, Korea and Vietnam were the first countries to significantly feel the rivalry between the two super powers as conflict emerged in these countries. In the 1960s the influence of the Soviet Union spread to Africa and then to the Americas, particularly with the support of Fidel Castro's Cuba. In 1962, the United States and Soviet Union almost risked nuclear war following America's discovery of the USSR missile base in Cuba which it interpreted as threatening its security. The possibility of a nuclear war was avoided by the USSR agreement to remove its missiles from Cuba.

\subsubsection{The cold war in Asia}

One of the most significant events of the cold war era was the resurgence of Asia - a reality the West was unwilling to accept because it would erode the Western influence in this region 
(Woodruff, 1981). China was among the first Asian countries to become free, by 1939, from the control of the West, but a large part of the Chinese coastal regions and Manchuria were under the control of Japan. The other parts of China were administered by the Nationalists championed by Chiang Kai-shek and the Communists under Mao Tse-tung (Woodruff, 1981). The Japanese primary motive was to conquer the entire China and prevent the influence of other great powers in China. The Nationalist objective was to prevent the spread of communism to the rest of China. This resulted in a civil war in the country. Occasionally the Nationalists and Communists rallied round the flag to fight against the common imperial enemy - Japan (Robertson, 1975). Following the United States declaration of war against Japan in 1941, the United States began to provide military aid to the Nationalists.

With the end of the World War II and the attendant surrender of Japan, the civil war in China intensified. Despite the support the Nationalists received from the United States, the Communists became stronger with the support of the USSR. The Communists finally conquered the Nationalists in 1949. The relationship between USSR and China became strained in the 1960s. During this period, China disagreed with Khrushchev's policies of peaceful coexistence with the Westand with the Soviet's military aid to India. Another source of conflict between the two states was territorial and predated the 1960s. China laid claim to the Soviet Far East and Soviet Central Asia. China also claimed rightful ownership of Kazakhstan, Uzbekistan, Kirghizia and Tadzhikistan. This territorial dispute nearly led to a nuclear war between China and the Soviet Union in 1969 and 1979. The ideological rivalry between the two communist states was also a source of conflict. The Soviet Union accused China of embracing Mao's more dangerous brand of communism rather than Marx's (Woodruff, 1981).

While hostilities between communist states increased, China and America began to develop closer ties. With the approval of the United States and its allies, in place of the Nationalists, the People's Republic joined the United Nations. President Nixon visited Peking in 1972 and the United States liaison offices were set up after the historical visit. The cordial relationship with China required that the United States adjust its international behaviour to accommodate the interests of China. For instance, the United States ended its diplomatic ties with Taiwan - the abrogation of the 1954 defense pact and the removal of its troops from Taiwan (Woodruff, 1981). 
Like Germany, Korea was divided into a communist state in the North and a democratic state in the South following a struggle for sphere of influence by the great powers after the Second World War. With the approval of the Soviet Union, in 1950, North Korea invaded South Korea with the hope of uniting the Koreans under communist rule. The United States and the United Nations came to the rescue of South Korea. The war dragged on, more particularly due to China's involvement. In the winter of 1950, China joined the war on the side of North Korea. The Chinese troops enjoyed a supply of arms from the Soviet Union. It was the Chinese troops who frustrated the efforts of the United Nations to make meaningful progress in conquering North Korea. The war ended in 1953 with the signing of an armistice by the two parties which stipulated that the status quo prior to the war should be maintained. Korea remains divided to date along the ideological divide of the super powers (Woodruff, 1981).

The struggle between the Vietnamese communists and the French coloniser led to a war of national liberation. The Chinese aid was instrumental to the communists' decisive defeat of France in 1954. Following the embarrassing defeat, some states met at the Geneva conference to decide how France could peacefully withdraw from Vietnam and to discuss the future of the wartorn state. The conference called for a ceasefire and the withdrawal of France. It also called for the partition of Vietnam into communist North and non-communist South (Dunbabin, 1994). With the hope of unifying the Vietnam under the communist rule, North Vietnam invaded South Vietnam. It would have achieved its objective with little or no impediment but for the intervention of the United States troops in 1965. The United States was able to draw support from South Korea, Australia and New Zealand for troops but not the Western European countries (Dunbabin, 1994). North Vietnam received massive economic and military support from USSR and China. In 1975, the North Vietnam troops defeated the United States-led troops and consequently conquered South Vietnam. Following this victory, communist regimes were established in Laos and Cambodia (Dunbabin, 1994).

\subsubsection{The cold war in southern Africa}

Prior to the 1970s the United States did not consider southern Africa of strategic importance and Washington was not overly involved in the affairs of the countries located in this region. Britain and Portugal were the dominant powers in the region. Washington had heavily relied on Britain and France to promote its interests in the region (Potter, 1992). In the 1970s, Angola and 
Mozambique gained independence from Portugal, and the British influence in this region was also in decline, particularly following the developments in Southern Rhodesia (Zimbabwe). The Soviet Union and Cuba arrived to fill the vacuum. The Soviet Union supplied massive troops to the Popular Movement for the Liberation of Angola (MPLA). The Soviet Union's influence in Mozambique and a number of southern African countries was increasing. "By the early 1980s every state in the region except Malawi, Swaziland and South Africa had a Soviet embassy and most states also hosted diplomats from Cuba, Vietnam, North Korea and Eastern European countries" (Potter, 1992, p. 57).

Among other factors, the American public opinion which was against United States intervention after the Vietnam war and the likelihood of Washington's involvement being interpreted as supporting Apartheid South Africa, prevented the United States' desire to curtail increasing influence of the USSR in this region. The American interest in the region skyrocketed during Reagan's regime. However, by the late 1980s the United States' interest in southern Africa began to wane with the realisation that the actions and policies of the region would not significantly affect American interests. "There was a more relaxed view about even the notionally Soviet aligned states of Angola and Mozambique, for it had become clear then that such regimes are not irredeemable" (Potter, 1992, p. 57). The United States also realised that communism in the region did not significantly benefit the Soviet Union as was evident in Soviet Union's inability to gain significant control over its client states of Angola and Mozambique and other states in the region. In addition, in the conference held towards the end of 1980s, Marxists in Africa agreed that they could not rely on the Soviet Union in the transition to socialism.

\subsubsection{The cold war in Central America and Cuba}

Nicaragua under the Somoza dynasty enjoyed close relations with the United States. However, the dynasty was corrupt, incompetent and often relied on torture and air bombings to punish political opponents. It was amidst such oppressive tendencies of this regime that revolutionaries realised the imperative to overthrow the Somoza dynasty. Consequently, the Sandinista revolutionaries, with the aid of Cuba, became victorious in 1979 (LaFeber, 1994). The emergence and apparent legitimacy of the socialist Sandinista regime in Nicaragua informed the United States' 1980s policies in the region. It was widely believed in Washington that the regime was "communist and pro-Soviet" (McGrew, 1992, p. 61). The development in Nicaragua 
was particularly worrisome for Washington because of the conviction that if the regime was allowed to flourish, it would become a base for the spread of communism in America which would be significantly detrimental to Washington's interests and national security. In this light, the United States throughout the 1980s exercised dominance in this region aimed at curtailing the spread of communism.

The United States' hegemonic posture in the region predates the 1980s. In the 1950s and 1960s, the United States policy in Central America was primarily to prevent a communist revolution. The policy was executed in two ways: firstly, military and covert intervention as evident in states like Dominican Republic in 1965 and Guatemala in 1954 to install or maintain regimes that promote American interests, and secondly, after the Cuban revolution, America realised the urgency to provide economic and military aid to forces that sought to crush the Cuban or Soviet inspired revolutionary movements. "US policy towards Central America appeared increasingly paradoxical: in the fight against communist totalitarianism it was engaged in alliances with highly undemocratic regimes" (McGrew, 1992, p. 68). In the mid 1980s, Congress banned the US support of the Contra rebels - counter-revolutionary forces in Nicaragua. However, the Reagan administration continued to covertly support the rebels through the provision of arms and training of the commandoes. The US soldiers and military advisers were deployed in El Salvador, Honduras and Guatemala. According to Blum (2003):

Throughout the 1960s, multifarious American experts occupied themselves in El Salvador by enlarging and refining the state's security and counter-insurgency apparatus: the police, the National Guard, the military, the communications and intelligence networks, the coordination with their counterparts in other Central American countries ... (p. 353)

Following the incessant killings of protesters and critics by the El Salvadoran military government in 1979, young military officers staged a coup to overthrow the General Carlos Romero administration. The coup plotters had desired reform and incorporated some civilian politicians in the regime. However, the pressure mounted by the United States and older military officers ensured that key positions were left in the hands of military officers. Therefore the reformists were denied strategic positions through which they could implement their proposed reform (Blum, 2003). The United States military expenditure in this country was extremely high in this period. In the words of Blum, "the amount of American military aid to El Salvador from 
1980 to the early 1990 s, for the hardware alone, ran into the billions of dollars" (Blum, 2003, p. 357).

Particularly in Nicaragua, the United States halted the provision of loan and aid facilities. The United States' actions were perpetuated in the belief that these would curtail the spread of communism in the region and establish a solid American hegemony. However, the Sandinistas' regime drifted more and more to Cuba and the Soviet Union who provided military and economic assistance for the regime. The United States soon realised the need to intensify its military and security operations in its nearby countries. US military bases were established in Honduras. The United States proved it would use whatever means to attain its objectives in Central America when in 1983 it invaded Grenada.

After the 1959 Cuban revolution, the Cuban state became a source of tension between the United States and the Soviet Union. Cuban ideological and security relationships with the Soviet Union were particularly worrisome for the United States (LeoGrande, 1998). This development was widely believed to have the potential to greatly threaten the security of the United States. Therefore, it is not surprising that the United States had been hawkish in its relation with Cuba most especially between 1959 and the beginning of the 1970s as was evident in the 1961 Bay of Pigs invasion. The United States tried unsuccessfully to dislodge the Fidel Castro-led communist regime in Cuba. America was accused of assassination attempts against Castro who once argued that "if surviving assassination attempts were an Olympic event, I would win a gold medal" (The Independent, 2013).

There was also an economic embargo and Cuba was internationally isolated. In the 1970s there was a conscious attempt to establish friendly relations between the two countries. There were negotiations under the administration of Ford and Carter, however, they did not yield positive results and in the 1980s there was a return to the antagonistic relationship of the 1960s (LeoGrande, 1998). The major reasons for the strained relationship were Cuban close ties with the USSR and its support for Latin American revolutionaries. Cuba had a military presence in almost all strategic parts of the world. Fidel Castro's global entanglement stems from his realisation of the imperative to counteract Washington's hostile policies against Cuba and to garner support from the Soviet Union and other Communist regimes for Cuba's economic 
development (Dominquez, 1997). Cuba was therefore a most dependable ally of the USSR during the cold war and it is not surprising that Cuba received massive military and economic aid from the Soviet Union (Dominquez, 1997). It is also interesting that the American public opinion did not favour Cuba. LeoGrande observed that:“A May 1960 Gallup poll found that 81 percent of the public had a negative opinion of the Cuban regime, and only 2 percent a positive opinion. A year later, Gallup found that 63 percent of the public supported a trade embargo on Cuba "so long as Castro is in power" (LeoGrande, 1998, p. 69)

During the Eisenhower regime, the CIA orchestrated a strategy to dislodge Fidel Castro from power. The President not only approved the plan, he even endorsed the commencement of preparations towards the implementation of the strategy particularly the CIA training of Cuban exiles. Policy makers had believed that the invasion would erupt in an uprising against Castro's administration like the invasion of Guatemala in 1954 (Vandenbroucke, 1984). The invasion was not carried out during Eisenhower administration but it had reached its apex in terms of preparation. With the arrival of the Kennedy administration, the plan was put into force in 1961. CIA trained Cuban exiles were mostly involved. Kennedy did not provide United States air cover due to his conviction that the USSR might attack West Berlin in retaliation if the United States was perceived to be directly involved. Therefore, the invasion was carried out in April 17, 1961 by 1500 forces without air cover. In a matter of hours, the Cuban troops were victorious and no uprising occurred as envisaged by the United States. The Kennedy administration and United States in general were humiliated following the defeat (LaFeber, 1994).

In October, 1962, the United States U-2 plane took aerial photographs of missiles in Cuba which were installed by the USSR. On October 22, in a televised speech, Kennedy called for the removal of the missiles and argued that if the United States was attacked by the weapons, it would engage in massive reprisal attacks against the Soviet Union (LaFeber, 1994). Khrushchev was quick to justify his actions. He wrote:

The Americans had surrounded our country with military bases and threatened us with nuclear weapons, and now they would learn just what it feels like to have enemy missiles pointing at you ; we'd be doing nothing more than giving them a little of their own medicine. ... After all, the United States had no moral or legal quarrel with us. We hadn't given the Cubans anything more than the Americans were giving to their allies. We had the same rights and opportunities as the Americans. Our conduct in the international arena was governed by the same rules and limits as the Americans. (quoted in Blum, 2003, p.?) 
Expectedly, a crisis ensued - the Cuban missile crisis - with the possibility of a nuclear confrontation between the two super powers. The origin of the crisis could be linked to a couple of months before October when Nikita Khrushchev had the idea of installing a missile facility in Cuba while preparing for a trip to Bulgaria where he delivered speeches condemning United States missile sites in Turkey, a neighbouring country of the Soviet Union. USSR also believed that the site in Cuba would deter the possible United States invasion of Cuba that would prevent the Cuban revolution and dismantle the spread of communism in the Western hemisphere (Rosenau \& Durfee, 1995). However, owing to the United States display of military arsenal and the apparent determination to risk a nuclear war, Khrushchev decided to remove the missile facility with the conditions stated in two letters to the United States. In the first letter, he wrote that the missiles would be dismantled if the United States would pledge not to invade Cuba but before Kennedy replied the letter, a second letter was sent demanding that the United States destroy its missile facility in Turkey (LaFeber, 1994).

On 28 October President Kennedy disregarded the second letter but replied to the first letter stating the United States would not invade Cuba, if the Soviet Union dismantled and removed the missiles from Cuba. Kennedy's response signaled the end of the Cuban missile crisis. In 1963 the United States removed the missile facility from Turkey, a decision believed to have been influenced by negotiations between the two super powers (Rosenau \& Durfee, 1995).

\subsubsection{The end of the cold war and the unipolar order}

There is lack of consensus among scholars regarding the major factors leading to the end of the cold war. Some felt that it was as a result of the Soviet Union engagement in the arms race with the United States at the expense of its economy, most especially during the Reagan administration, that facilitated the collapse of the USSR. Others argued that the external influence did not contribute significantly to the USSR collapse. They argued that the collapse was as a result of decade long internal stagnation (Goldstein, 2008; Kalashnikov, 2011; StonerWeiss \& McFaul, 2009). Despite differing opinions on this historic event, what everyone seemed to agree upon was that in the 1980s the USSR waged a frustrating war in Afghanistan, coupled with the realisation that its economy could no longer sustain the cost of the military requirement of the cold war, and therefore saw the need to look inward and concentrate on boosting its economy rather than continuing an arms race with the United States. The focus on domestic 
reform meant that the USSR commitment to sustain the communist regime in Eastern Europe plummeted. Accordingly, in 1989 the Berlin wall fell and East and West Germany became united. Between 1989 and 1990 elections were held that ousted the communist regimes in power across Eastern Europe and in 1991, the Soviet Union disintegrated into 15 independent states (Kaarbo \& Ray, 2011). These incidents marked the end of the war.

Following the collapse of the Soviet Union, two major positions dominated scholarly and journalistic theories regarding the power configuration that would emerge. Firstly, it was speculated that the United States would withdraw from global politics and possibly once again embrace its isolationist policy. By implication, other great powers would exert their influence on international politics owing to the vacuum created by the two super powers. Alternately, the United States would exert its influence as the sole surviving super power and would strive to establish global hegemony (Smith, 2002), which is what ultimately happened

The end of the cold war and the war on terrorism are the two major events that have significantly shaped the post-1989 patterns of global politics. The end of the cold war and the subsequent disintegration of the USSR catapulted the United States into the position of the sole super power in the global arena. The United States emerged as the only state that could singlehandedly deploy its military arsenals in all strategic parts of the world. In addition its economy was second to none. Given these realities, scholars and commentators were quick to label the structure of power in the immediate period after the cold war as a "unipolar order". Krauthammer (1990) argued that the most important characteristic of the post-cold war period was the unipolar configuration. While he argued that multipolarity would eventually emerge when other great powers developed capabilities that could challenge the dominance of the United States, it was likely that this would take a generation. He described the period immediately following the end of cold war as a "unipolar moment". He identified Germany and Japan as economic powers. He also recognised diplomatic relations and military capabilities as the sources of power for Britain and France. Russia continued to wield military, political and diplomatic powers but rapid decline was the common characteristics of these great powers. The implication of this is that while other great powers may challenge the United States in one component of power, no great power matches the completeness of the United States' capabilities. Consequently, Washington enjoys preponderance in all components of power - military, economic, diplomatic, technological and 
soft power. With this reality, Washington can act decisively across the globe sometimes with the aid of its Western allies. Krauthammer wrote:

Perhaps it is more accurate to say the United States and behind it the West, because where the United States does not tread, the alliance does not follow. That was true for the reflagging of Kuwaiti vessels in 1987. It has been all the more true of the world's subsequent response to the invasion of Kuwait. American preeminence is based on the fact that it is the only country with the military, diplomatic, political and economic assets to be a decisive player in any conflict in whatever part of the world it chooses to involve itself. In the Persian Gulf, for example, it was the United States, acting unilaterally and with extraordinary speed, that in August 1990 prevented Iraq from taking effective control of the entire Arabian Peninsula. Iraq, having inadvertently revealed the unipolar structure of today's world, cannot stop complaining about it. (1990, p. 24)

Contrary to the conventional belief that Washington's foreign entanglement could erode its economic strength, Krauthammer was of the opinion that it was strategic in that it enabled the super power to create a stable international system in which it could meaningfully pursue its economic interests. Therefore, it goes without saying that United States dominance in all components of power is the most salient feature of post-cold war international politics. The "perceptions, calculations, and possibilities available to all other states, as well as to other consequential international actors" are determined by Washington's position (Walt, 2009, p. 93). Walt further argued that in today's world, states are not only being influenced by America's capabilities but by its geographical location, institutional arrangement that emerged during the cold war and Washington's liberal ideals. Fukuyama (1992) argued that the end of the cold war signified the triumph of Western liberalism which manifests in the economic realm as capitalism and the political realm as democracy. The disintegration of the Soviet Union marked the end of communism - an ideology which had rivaled the liberalism championed by the United States during the cold war. Therefore, states had no alternative to Western liberalism after the cold war. The unipolar structure enabled the United States to take decisions with little or no concern for the perception of other great powers, a position that was not possible during the cold war. For instance, the United States was cautious in the Korean and Vietnamese wars because of the opposition of the USSR (Walt, 2009).

The result is the dominance of a single power unlike anything ever seen. Even at its height Britain could always be seriously challenged by the next greatest powers. Britain had a smaller army than the land powers of Europe and its navy was equaled by the next two navies combined. Today, American military spending exceeds that of the next twenty countries combined. Its navy, air force and space power are unrivaled. Its technology is irresistible. It is dominant by every measure: military, economic, technological, diplomatic, cultural, even linguistic, with a myriad of countries trying to fend off the inexorable march of Internet-fueled MTV English. (Krauthammer, 2003, p. 6-7). 


\subsection{The Bush doctrine}

The dominance of the United States appeared to be unchallengeable in the immediate period of the post-cold war in the major components of power. With the arrival of the Clinton administration, the United States economy experienced a remarkable boom and America's soft power currencies such as its culture of language, fast food, jeans, music and films, spread to other countries. These realities contributed to an image of an invincible state of America in the minds of Americans and citizens of other countries. However, this image of invincibility was shattered with the September 112001 attacks on the Pentagon and the World Trade Centre in the United States allegedly carried out the al-Qaeda group led by Osama bin Laden. The United States' response to these attacks was decisive and has been labelled the Bush doctrine. It was outlined in major speeches by President George W Bush and his officials following the terrorist attacks and included four major principles: firstly, a belief in democratic peace. If all states could become democratic, there would be a common interest in promoting peace and stability in the international system and the interests of America by extension would not be jeopardised. Secondly, there is an enormous threat from terrorist groups, autocratic regimes and weapons of mass destruction. Thirdly, the willingness of the United States to engage in preventive wars is not sufficient to curb these threats. Fourthly, if the need arises, the USA would act unilaterally. The doctrine implied that the United States would engage in a war on terrorism, would work towards "democratic globalism" and would assert global hegemony (Jervis, 2005, p. 351).

The willingness to carry out preventive wars is directly linked to the unilateral posture of Bush's administration. It was with the realisation that the United States would not always enjoy the support of its allies to pursue its agenda that the clause of unilateralism emerged in the doctrine. Despite Washington requesting the support of other states in its war on terrorism, particularly in Afghanistan and Iraq, the preferences of the other states was not taken into consideration in waging the wars. America argued that it would rather suffer the involvement of any country than compromise (Jervis, 2007). In his state of the union address in 2002, according to George Bush "you are with us or against us" in the war on terrorism. The unilateral posture was evident in the Bush administration prior to 9/11 when United States interests clashed with the world's interests. This was reflected in Bush's decision not to endorse the Kyoto Treaty, the International Criminal Court, and the protocol implementing the ban on biological weapons (Jervis, 2007). The United 
States unilateral tendencies reached a peak following $9 / 11$ as the doctrine established what some observers have described as an American empire. Cox asserted that:

Whether or not the United States now views itself as an empire, for many foreigners it increasingly looks, walks and talks like one, and they respond to Washington accordingly. There is certainly no reason for American policymakers to refer to the United States as such in policy pronouncements, but an understanding of America as an evolving, if reluctant, modern empire is an important analytic tool with profound consequences that American leaders should understand. (Cox, 2004, p. 593)

Contrary to the belief of a plethora of scholars who posited that September 11 and the subsequent Bush doctrine instigated America's image decline across the globe, Krauthammer (2003) strongly argued that September 11 reinforced the gap between the United States and the other great powers. He highlighted three ways in which the incident further strengthened America's power. Firstly, it revealed Washington's military capability. He argued that while the Kosovo war which was waged and won from the air demonstrated the American capability to an extent, it was September 11 that provided clear evidence of the military capability of the United States as it waged its short decisive war in Afghanistan. In the difficult terrain of Afghanistan, America displayed its military prowess by invading and toppling the Afghan Taliban regime in a matter of weeks. Secondly, it revealed the resilience of American power. The symbol of its economic and military capabilities - the World Trade Centre and Pentagon - were attacked and devastated. Consequently, the entire country was in a state of fear and economic and political activities were stalled. However, within a couple of days, the economy started to recover and the President mobilised the entire nation in a war on terrorism. Thirdly, the United States garnered the support of other states in its war in Afghanistan. Countries which had not been allies previously now supported Washington. Russia offered its support and also China. Countries like India and Pakistan also provided backing to the US (Krauthammer, 2003).

While the United States enjoyed enormous support in its war in Afghanistan, the super power did not receive similar support for its war in Iraq. Its appeal in the United Nations for the invasion of Iraq on the grounds of Saddam Hussein's possession of weapons of mass destruction fell on deaf ears. Washington therefore unilaterally invaded Iraq. The other great powers protested but no state considered counteracting the perceived United States' global dominance and it is not surprising that the National Intelligence Council's (NIC's) Mapping the Global Future 2020 report, published in 2004, was convinced that unipolarity would be long-lived. The report recognised the reality of the challenges faced by the United States such as the rise of Asia, the 
resurgence of Russia and the challenges of globalisation, but claimed that war was unlikely to result between the great powers for the next decade and half and that the United States would shape international politics till 2020 (Edelman, 2010).

\subsection{Conclusion}

Perhaps what makes international politics in the twentieth century so fascinating is that all three traditional models of polarity (unipolarity, bipolarity and multipolarity) and the struggle for power (through alliances and bandwagoning) that characterise these systems were evident. The current chapter has explored the power politics among the great powers in this era. In the nineteenth century, Europe was the centre of international politics with France and Britain the most important players in terms of capabilities and influence. By the twentieth century the centre of world politics shifted from Europe following the emergence of powerful states in other continents such as the United States in America and Japan in Asia. The twentieth century, which had begun with a multipolar structure of power, was distorted by the two world wars which had significant impacts on the power configuration in the international system. In other words, the capabilities and influence of the great powers, except those of the United States and the Soviet Union, declined as a result of the war. With the end of the Second World War, the international system became bipolar with the United States and the Soviet Union emerged as the only super powers. Barely 50 years after the beginning of the cold war, the USSR collapsed and the United States has remained the sole super power till the close of the twentieth century.

As we look forward into the twenty-first century, will the United States maintain its hegemony? This is the question the next chapter seeks to explore by examining the hard and soft power sources of the United States in contemporary international politics. 


\section{CHAPTER FOUR \\ United States: Stable or Vanishing Hegemony}

\subsection{Introduction}

The United States foreign policy has interestingly swung between isolationism (withdrawal from world politics) and internationalism (engagement in world politics). Klingberg observed that American foreign policy has oscillated in cycles of "introversion" (isolationist) and "extroversion" (interventionist). He argued that each of the cycles takes a period of about twenty five to thirty years before it gives way to the next cycle. The pattern of the cycles and how they have manifested between the $18^{\text {th }}$ and $21^{\text {st }}$ centuries is presented below in Table 4.1.

Table 4.1: Introversion and extroversion patterns of cycles

\begin{tabular}{|l|l|l|l|l|l|}
\hline Introversion & $1776-1798$ & $1824-1844$ & $1871-1891$ & $1919-1940$ & $1967-1986$ \\
\hline Extroversion & $1798-1824$ & $1844-1871$ & $1891-1919$ & $1940-1966$ & $1986-2014$ \\
\hline
\end{tabular}

Source: Kegley \& Wittkopf, 1991, p. 36)

Prior to the First World War, the United States played a very limited role in world affairs. The eruption of World War I and the destruction of Europe left the United States with no option but to intervene in the war. With the end of the war in 1918, the United States withdrew from global affairs and continued with its isolationist policy. However, this policy was bound to be temporary as World War II dragged Washington in again. By the end of the war, America had emerged as the undisputed most powerful state in the international system particularly in terms of its robust economy and its status as the sole country with nuclear weapons. Russia had also emerged as a powerful country with communism providing an alternative to western liberalism. With these realities, Washington realised the need to completely abandon isolationism and fully engage in global politics, firstly, to rescue the European economies that had been devastated by the war, and secondly, to prevent the spread of communism across the globe.

The end of World War II in 1944 was followed by another historic war - the cold war - in which international politics was dominated by the power politics between the two super powers - the United States and the Soviet Union. By the end of 1989, the Soviet Union disintegrated and 
Washington emerged as the undisputed hegemon in global affairs. Following this incident, the United States was dominant in all components of power, both hard and soft. Suddenly, the bipolar configuration that had characterised the cold war era had given way to a unipolar order with the United States as the single pole. The United States was able to influence states - big or small, powerful or weak - and dominated notable international organisations across the globe.

However, the United States arrogance, unilateralism and its economic problems have altered the realities of the immediate post-cold war era. In the $21^{\text {st }}$ century, unpopular United States foreign policy and its economic challenges have stimulated the rise of emerging powers and an antihegemonic coalition which seeks to challenge the hegemony of the United States. This has generated questions regarding the capability of the United States amidst contemporary global politics realities. To this end, the objective of this chapter is to investigate the United States power profiles, both in terms of hard power and soft power, in today's world and how this translates to a stable or vanishing hegemony. In doing this, the chapter explores the economic and military strength of the United States. Furthermore, it investigates how the American culture, domestic values and foreign policies translate into soft power. In addition, the chapter investigates the extent to which America wields its soft power resources in the strategic regions of Africa and the Middle East. It further explores the debate on the American decline. The chapter concludes that despite the relative decline of the United States, the super power still enjoys dominance in certain respects.

\subsection{The United States hard power profiles}

According to Wohlforth (1999), a state is only eligible for polar status if it excels in all components of power - economic, military, population, territorial and so on. In this regard, the United States is the only state that comprehensively meets these prerequisites. No other state matches the completeness of American power in all major components of power, both hard and soft. The United States preeminence in the globe has been largely maintained over the years by its economic and military capabilities. The robust economy of the super power has been instrumental towards its acquisition and accumulation of military hardware and its projection of soft power. The combined military and economic might have enabled Washington to influence decisions of global consequences. 
The end of cold war and the subsequent demise of the Soviet Union's communism symbolised the "end of history". This meant the United States could promote and spread western liberalism which manifests in the political realm as democracy and in the economic realm as capitalism with no hindrance as it had no challenger to its hegemony across the globe. The ideology has subsequently "created unprecedented amounts of wealth and lifted more people out of poverty than any other political or economic system" (Norrlof, 2010, p. 15). According to Norrlof (2010), the American economic model, coupled with its strong institutions have significantly facilitated high growth in GDP, trade, and international security in the last sixty five years. In this period, it maintained the largest economy and dollars were the most important currency in the international economic architecture (Norrlof, 2010). America's economy is more robust than any other state's economy in history.

The only exception to the generalisation is America itself in 1945 after all the other great powers had been destroyed and devastated by World War II (Brooks \& Wohlforth, 2002). Jentleson (2007) observed that the United States share of the world's gross domestic product (GDP) stands at 25\%. Similarly Xinbo (2010) argued that between 1999 and 2001, the United States' GDP accounted for over $28 \%$ of world's GDP. This percentage that accrues to Washington in world's economy is equivalent to the combined percentage of the next three largest economies (Nye, 2008). As the largest economy, the United States has used its position to ensure organisations like the IMF, the World Bank and G8 promote free flow of goods and services in the international system. Owing to its position, the United States is also able to promote its economic interests (Starrs, 2013). This can explain why Americans have the highest standard of living in the history of mankind (Norrlof, 2010). Table 4.2 that follows shows the GDP of the ten largest economies and the overall world total GDP in 2012. 
Table 4.2: The world's ten largest economies in 2012

\begin{tabular}{lll}
\hline Rank & Country & $\begin{array}{l}\text { GDP (trillions of US } \\
\text { dollars) }\end{array}$ \\
\hline 1 & United States & 16,245 \\
2 & China & 8,227 \\
3 & Japan & 5,960 \\
4 & Germany & 3,428 \\
5 & France & 2,613 \\
6 & UK & 2,472 \\
7 & Brazil & 2,253 \\
8 & Russian Federation & 2,015 \\
9 & Italy & 2,015 \\
10 & India & 1,842 \\
\hline & World Total & $\mathbf{7 2 , 4 4 0 , 4 4 9}$ \\
\hline
\end{tabular}

Source: World Development Indicators Database, World Bank, 2013

As evident in Table 4.2, the United States is by far the largest economy in the world. Its economy almost doubles that of its closest rival - China - a country widely assumed to be the greatest competitor of the United States, most especially in the economic realm. As rightly observed by Nye about half a decade ago, the United States' GDP still nearly equals the total GDP of the next three great powers which stands as $\$ 17,615$ as against the United States $\$ 16,245$. It can also be deduced from the table that the United States enjoys 22 percent of the global GDP which is close to one-quarter of the world's GDP, as argued by Jentleson (2007). The implication of this is that the United States still enjoys preponderance in terms of Gross Domestic Product even though other countries, most importantly the emerging powers, are rising fast as a result of the recorded growth rates in these countries.

While some scholars doubt whether the United States can be regarded as an economic hegemon, there is little or no disagreement with respect to the military dominance of the United States. Posen (2003) vigorously argued that America enjoys "command of the commons" which implies that the United States enjoys dominance in the military use of the sea, space and air and has the capacity to prevent other countries the use of the commons. The US command informs the dominant position of the United States in international politics and also enables it to excel in other components of power. This command has also enabled the United States to fight impromptu wars even in areas where it had no significant military presence, as was evident in 
Iraq, Somalia and Afghanistan in 1991, 1993 and 2001 respectively (Posen, 2003). The United States military expenditure is second to none. America's military spending dwarfs its closest contenders. "America spends more on its military than the next 15 nations combined" (Jentleson, 2007, p. 181). During the cold war, the Soviet Union was its closest competitor and in 1998, it accounted for 18 percent of global expenditure. The second largest military spender in today's world is China and it only accounts for 5 percent of the world's total. The military budget of a supranational organisation like the European Union is less than half of America's military expenditure. Also, in terms of the sophistication of the United States military, no state or coalition of states comes close (Norrlof, 2010). Posen (2003) has described the sophistication of the United States military in detail:

\begin{abstract}
At least on the matter of medium-to-large-scale military developments, the United States can locate and identify military targets with considerable fidelity and communicate this information to offensive forces in a timely fashion. Air power, ashore and afloat, can reach targets deep inland; and with modern precision-guided weaponry, it can often hit and destroy those targets. US forces can even more easily do great damage to a state's transportation and communications networks as well as economic infrastructure. When US ground forces do venture inland, they do so against a weakened adversary; they also have decent intelligence, good maps, and remarkable knowledge of their own position from moment to moment. Moreover, they can call on a great reserve of responsive, accurate, air delivered fire power, which permits the ground forces considerable freedom of action ... The specific weapons and platforms needed to secure and exploit command of the commons are expensive. They depend on a huge scientific and industrial base for their design and production. In 2001 the US Department of Defense budgeted nearly as much money for military research and development as Germany and France together budgeted for their entire military efforts. The military exploitation of information technology, a field where the US military excels, is a key element. The systems needed to command the commons require significant skills in systems integration and the management of largescale industrial projects, where the US defense industry excels. The development of new weapons and tactics depends on decades of expensively accumulated technological and tactical experience embodied in the institutional memory of public and private military research and development organisations. Finally, the military personnel needed to run these systems are among the most highly skilled and highly trained in the world. The barriers to entry to a state seeking the military capabilities to fight for the commons are very high. (pp. 9-10)
\end{abstract}

The United States possesses a second to none intercontinental nuclear arsenal, it has the most sophisticated air force, naval and ground forces with the capacity of presence in all areas in the globe (Nye, 2008). The United States military presence across the globe has guaranteed free flow of goods and services at sea and ensured commercial activities in places with weak property rights. It has used its role as the "self-appointed global policeman" to sustain the current international economic order (Starrs, 2013). America is the number one great power in utilising the military applications of sophisticated information and communications technology. It has also shown excellence in coordination and information processing on the battlefield and the 
ability to exterminate targets in faraway areas with precision that is unmatched. Its spending on military research and development $(\mathrm{R} \& \mathrm{D})$ is also extraordinary making it almost impossible to be challenged. Washington's military R\&D expenditure triples the total spending of the next six great powers. It is also worthy to note that the United States only spends 3.5 percent of its GDP on its military budget (Brooks \& Wohlforth, 2002, p. 22). Nye (2012) however put defense expenditure at 6 percent of the GDP. SIPRI places it at 3.7 and 4.4 in 2003 and 2012 respectively. The increment perhaps reflects the United States wars in Iraq and Afghanistan. Nye pointed out that this percentage is still less than the cold war expenditure which stood at 10 percent. The United States military spending accounts for almost half of global military expenditure. Therefore, it would be unrealistic for other states to challenge the United States military (Nye, 2008).. The table below shows the military expenditure of the top 15 countries in 2012.

Table 4.3: The 15 countries with the highest military expenditure in 2012

\begin{tabular}{lllcc}
\hline Rank & Country & $\begin{array}{l}\text { Spending } \\
\text { (\$billions) }\end{array}$ & $\begin{array}{l}\text { Share of } \\
\text { GDP }(\%)\end{array}$ & $\begin{array}{c}\text { World } \\
\text { Share }\end{array}$ \\
\hline & & & & \\
1 & USA & 682 & 4.4 & 39 \\
2 & China & 166 & 2.0 & 9.5 \\
3 & Russia & 90.7 & 4.4 & 5.2 \\
4 & United Kingdom & 60.8 & 2.5 & 3.5 \\
5 & Japan & 59.3 & 1.0 & 3.4 \\
6 & France & 58.9 & 2.3 & 3.4 \\
7 & Saudi Arabia & 56.7 & 8.9 & 3.2 \\
8 & India & 46.1 & 2.5 & 2.6 \\
9 & Germany & 45.8 & 1.4 & 2.6 \\
10 & Italy & 34.0 & 1.7 & 1.9 \\
11 & Brazil & 33.1 & 1.5 & 1.9 \\
12 & South Korea & 31.7 & 2.7 & 1.8 \\
13 & Australia & 26.2 & 1.7 & 1.5 \\
14 & Canada & 22.5 & 1.3 & 1.3 \\
15 & Turkey & 18.2 & 2.3 & 1.0 \\
Subtotal top 15 & & $\mathbf{1 4 3 2}$ & & $\mathbf{8 2}$ \\
\hline World total & & 1753 & 2.5 & 100 \\
\hline Sourc: SIPRI & & & &
\end{tabular}

Source: SIPRI

As evident in Table 4.3, the share of the United States at $\$ 682$ billion military expenditure is only slightly outweighed by the spending of the next 14 countries which stand at $\$ 750$ billion. The United States closest rivals like China, Russia, United Kingdom, Japan and France account 
for $\$ 166$ billion, $\$ 90.7$ billion, $\$ 60.8$ billion, $\$ 59.3$ billion and $\$ 58.9$ billion respectively. The implication of this reality is that no state comes close to competing with America in the military sphere. It is also worthy to note the table reveals that Washington only spends 4.4 percent of its GDP to achieve this feat, despite being the largest economy. France, which spends the same percentage of its GDP on its military can only account for $\$ 58.9$ billion. China, America's closest rival spends 2.0 percent of its GDP on its military which amounts to $\$ 166$ billion. As it stands, the United States spending quadruples China's expenditure. If China doubles its share of GDP on military spending to match the United States, it would be spending about $\$ 332$ billion, a figure which is still doubled by American spending. It is therefore not surprising that the United States share of world's military budget is 39 percent, China's share is 9.5 percent and Russia's is 5.2 percent.

An assessment of the United States capacity would not be accurate without measuring its noncoercive power. The following section explores America's status in terms of its soft power currencies.

\subsection{United States' soft power profiles}

According to Nye (2004a) the major currencies of a state's soft power are its culture, political values and foreign policies. He further argued that these resources serve as soft power of a state when they are attractive to others who are willing to emulate the state that possesses that capability. An interviewee (an American scholar) was of the opinion that the United States' soft power is based on its past achievements, on American cultural institutions such as its media and universities, and on its defense of certain liberal values (individual freedom, democracy, and human rights). ${ }^{13}$

\subsubsection{The American culture}

The ability of a state to project its soft power is informed by the extent to which such a state's culture is compatible with the values and ways of lives of other states. The United States can be seen as a "melting pot for different cultures" 14 which can be helpful in this regard. The American

\footnotetext{
${ }^{13}$ An interview with American scholar 1

${ }^{14}$ An interview with American scholar 1
} 
culture has made "the United States seem to others exciting, exotic, rich, powerful, trend-setting - the cutting edge of modernity and innovation" (Nye, 2004a, p. 12). According to Gardels:

America established consensual hegemony through the appeal of its ideas realised in practice - as the land of personal freedom, of equality under the rule of law, of social and economic opportunity. Abroad, these ideas informed the battle against Fascist and Communist totalitarianism and for decolonization and self-determination... The rise of the media-industrial complex in the US in the wake of postwar prosperity spread the message far and wide through the mass culture of Hollywood films and popular music. As the cineplex replaced the silver screen through the industrial-scale production of entertainment, domestic markets were rapidly saturated and new outlets were sought abroad. Once globalised, this American soft power not only beat out the competition, but helped undermine the hard power of the Soviet empire. (2005, p. 9)

Arguably, the United States gained soft power through its cultural exports during the cold war. Entertainment companies like theatres, operas and even museums were allowed to perform in the Soviet Union during the cold war. More importantly, the academic and scientific exchanges between the two super powers were pivotal in promoting the United States soft power in the Soviet Union; a number of the Soviet beneficiaries became leading advocates for human rights and liberation in their country (Nye, 2004a, p. 45).

Indeed, the main tools of soft power, particularly in the cultural realm, include the mass media, film industry, internet, cultural events, mode of life, exchange programmes, education, music, literature, sport, fast food, national languages and public diplomacy, and in these, the United States has incredible potential and advantage over other countries. ${ }^{15}$ Washington possesses cultural exports in the entertainment industry most especially in the area of music, film, media, and sport. The influence of Hollywood around the world cannot be overemphasised: its influence can be seen in the ways nationals of other states try to dress, talk and act like Americans. In 1961, a poet - Carl Sandburg - put it this way: "What, Hollywood's more important than Harvard? The answer is, not as clean as Harvard, but nevertheless, further reaching" (cited in Nye, 2004a, p. 47). The popular American hip hop and R \& B music are also widely enjoyed around the globe. This has resulted in the popularity of the American artists across the globe. Popular musicians like Jay Z, Beyonce, Rihanna, Chris Brown and Lady Gaga have had a massive influence on the global entertainment industry.

In the immediate aftermath of the fall of communism, American soft power was at its height. MTV had gone where the CIA could never penetrate. The warblings of Michael Jackson and Madonna were the Muzak of the new world disorder, their visages glaring out from every corner of the globe like statues of Lenin in the old Soviet Union. The arrival of CNN and the English-dominated Internet

\footnotetext{
${ }^{15}$ An interview with Nigerian scholar 1
} 
secured the global conquest: America now dominated the metaworld of images, icons and information. (Gardels, 2005, p. 10)

The table below shows the popularity of the top music artists in the world.

Table 4.4: Top 10 most popular musicians on twitter in 2014

\begin{tabular}{|c|l|l|l|}
\hline Twitter music rank & Name & Country & Followers \\
\hline 1 & Justin Bieber & Canada & $37,617,919$ \\
\hline 2 & Lady Gaga & USA & $36,218,810$ \\
\hline 3 & Katy Perry & USA & $35,048,911$ \\
\hline 4 & Rihanna & USA & $29,217,969$ \\
\hline 5 & Taylor Swift & USA & $26,317,147$ \\
\hline 6 & Britney Spears & USA & $25,757,555$ \\
\hline 7 & Shakira & Colombia & $20,373,031$ \\
\hline 8 & Justin Timberlake & USA & $18,854,773$ \\
\hline 9 & Jennifer Lopez & USA & $16,407,892$ \\
\hline 10 & Nicki Minaj & USA & $16,257,145$ \\
\hline
\end{tabular}

Source: Data accessed in June 2014 from Twitaholic ${ }^{16}$, http:/twitaholic.com/top100/followers/

Table 4.4 clearly indicates only two non-Americans (Justin Bieber and Shakira) were part of the top 10 most popular music artists. It is worth noting that even though these two artists are Canadian and Colombian respectively, they are both based in the United States. The Twitaholic top 100 most popular musicians' data reveal that the United States share of the data is 57 percent. The closest states to America are the United Kingdom at 14 percent and Puerto Rico at 5 percent. It therefore goes without saying that the United States dominates the world entertainment industry.

\footnotetext{
${ }^{16}$ Twitaholic is a popular official Twitter statistics provider.
} 
Owing to the openness and high standard of its universities, the United States attracts the most foreign students annually across the globe. In 2011, about 4.3 million international students were enrolled in tertiary institutions across the globe. Asian students accounted for 53 percent of the foreign students. China, India and Korea had the highest numbers of students in foreign tertiary institutions (OECD, 2013, p. 304). United States, Canada, Australia, France, Germany and the United Kingdom institutions enrolled over 50 percent of the foreign students. The United States accounted for 17 percent of these students, the United Kingdom figure was 13 percent, Australia, Germany and France enrolled 6 percent each and Canada had 5 percent (OECD, 2013, pp. 305307). Similarly UNESCO (2012) put the figures as follows: United States (19 percent), United Kingdom (11 percent), Australia (8 percent), France (7 percent), Germany (6 percent) and Japan (4 percent). The table below shows the places of origin of international students in the United States.

Table 4.5: Top five places of origin of international students in the US

\begin{tabular}{|c|l|l|l|l|}
\hline Rank & Place of origin & $2011 / 2012$ & $2012 / 2013$ & $\begin{array}{l}\text { Percentage of } \\
\text { total }\end{array}$ \\
\hline & World total & 764,495 & 819,644 & 100 \\
\hline 1 & China & 194,029 & 235,597 & 28.7 \\
\hline 2 & India & 100,270 & 96,754 & 11.8 \\
\hline 3 & South Korea & 72,295 & 70,627 & 8.6 \\
\hline 4 & Saudi Arabia & 34,139 & 44,566 & 5.4 \\
\hline 5 & Canada & 26,821 & 27,357 & 3.3 \\
\hline
\end{tabular}

Source: Opendoors, 2013

Table 4.5 reveals that the total number of foreign students in the United States in 2011/2012 was 764,495 . There was an increase in this number in $2012 / 2013$ to 819,644 . China ranks number one in the number of foreign students enrolled in the United States in both periods And there was a dramatic increase in the number of Chinese students between. The massive influx of Chinese students in 2012/2013 significantly influences the total increase in the number of international students enrolled in American universities. 
According to Friedman (2009) at the peak of the French and British power, their cultures shaped the world. Similarly, the twenty first century will be meaningfully molded by the American culture. Therefore, in order to have a good grasp of the $21^{\text {st }}$ century, the American culture must be understood because it will significantly define and shape contemporary international relations.

\subsubsection{American political values}

Core American values are embedded in the American creed. According to Huntington (2004) the United States citizens generally subscribe to the principles of liberty, equality, democracy, individualism, human rights, the rule of law and private property. While the extent to which the American citizens indeed subscribe to these values is debatable, the principles do represent America's global identity and image, and America strives to promote these principles across the globe.

Identifying America with the ideology of the creed enables Americans to claim that they have a "civic" national identity as contrasted with the ethnic and ethno-cultural identities of other countries. America is said to be more liberal, more principled, more civilized than those tribally defined societies. The creedal definition allows Americans to hold that theirs is an "exceptional" country because unlike other nations its identity is defined by principle rather than ascription and, at the same time, to claim that America is a "universal" nation because its principles are applicable to all human societies. (Huntington, 2004, p. 48)

These principles significantly drive American foreign policy as was evident in the United States cold war policy of containment. The policy was not only designed to check the spread of Soviet communism but also to promote liberalism, democracy and capitalism in the international system. With the collapse of the Soviet Union and the attendant demise of its brand of communism, the United States had nothing to challenge or curb the spread of its liberal ideas. This informed Fukuyama's End of History (1992) in which he asserted:

As mankind approaches the end of the millennium, the twin crises of authoritarianism and socialist central planning have left only one competitor standing in the ring as an ideology of potentially universal validity: liberal democracy, the doctrine of individual freedom and popular sovereignty. Two hundred years after they first animated the French and American revolutions, the principles of liberty and equality have proven not just durable but resurgent. (p. 42)

Table 4.6 that follows shows the number and percentage of countries with electoral democracy in the world between 1989 and 2012 . 
Table 4.6: Electoral democracies, 1989-2012

\begin{tabular}{|c|c|c|c|}
\hline Year under review & $\begin{array}{c}\text { Total number of } \\
\text { countries }\end{array}$ & $\begin{array}{c}\text { Number of electoral } \\
\text { democracies }\end{array}$ & $\begin{array}{c}\text { Percentage of } \\
\text { electoral democracies }\end{array}$ \\
\hline 2012 & 195 & 118 & 61 \\
\hline 2011 & 195 & 117 & 60 \\
\hline 2010 & 194 & 115 & 59 \\
\hline 2009 & 194 & 116 & 60 \\
\hline 2008 & 193 & 119 & 62 \\
\hline 2007 & 193 & 121 & 63 \\
\hline 2006 & 193 & 123 & 64 \\
\hline 2005 & 192 & 123 & 62 \\
\hline 2004 & 192 & 119 & 61 \\
\hline 2003 & 192 & 117 & 63 \\
\hline 2002 & 192 & 121 & 63 \\
\hline 2001 & 192 & 121 & 63 \\
\hline 2000 & 192 & 120 & 61 \\
\hline 1999 & 192 & 120 & 61 \\
\hline 1998 & 191 & 117 & 62 \\
\hline 1997 & 191 & 117 & 60 \\
\hline 1996 & 191 & 118 & 59 \\
\hline 1995 & 191 & 115 & 57 \\
\hline 1994 & 191 & 113 & 53 \\
\hline 1993 & 190 & 108 & 49 \\
\hline 1992 & 186 & 99 & 46 \\
\hline 1991 & 183 & 89 & 41 \\
\hline 1990 & 165 & 76 & 69 \\
\hline 1989 & 167 & & 63 \\
\hline
\end{tabular}

Source: Freedom House, 2013

As Fukuyama (1992) rightly pointed out the growth of liberal democracy and capitalism has been the most significant political trend in the last four hundred years as illustrated in Table 6 . There has been a dramatic spread of democracy since the collapse of the Soviet communism in 1989. As evident in the table in 1989, there were 69 democratic regimes - a figure which 
represents 41 percent of the 167 countries investigated. In 2012, there were 118 electoral democracies - 61 percent of the 195 countries. The clear implication is that there has been a remarkable 20 percent growth in the number of electoral democracies between 1989 and 2012. This clearly reveals that democracy and human rights are enormously attractive across the globe. The states in the table have adopted a political system that represents the American identity in the international system, even if the triumph of democracy in some of these states might be informed by domestic pressure rather than by direct external forces. . The efficacy of the spread of democracy was demonstrated in the Arab spring, a region which had been predominantly authoritarian and anti-democracy. The citizens of the Arab world began to demand more participation in governance and some called for the total overthrow of the political order as was evident in Egypt and Libya.

Extremists find individualism and liberty absolutely repugnant. American feminism, open sexuality and individual choices are not tolerated in patriarchal societies and some religious fundamentalists dislike the United States because of its values of openness, tolerance and opportunity (Nye, 2004). However, most people find individualism and liberty attractive (Nye, 2004). People want the American political ideal of liberty - "you can say what you want, you can insult the president and there is presidential election every four years". ${ }^{17}$ The political values of individualism and, by extension, the work ethic, are highly attractive to foreigners. The American public polls have often shown that one's success is largely a function of one's own talent and character. This was further reinforced by President Clinton when he asserted that: "the American dream that we were all raised on is a simple but powerful one - if you work hard and play by the rules you should be given a chance to go as far as your God-given ability will take you" (Huntington, 2004, p. 70). America is very attractive to immigrants and they often excel in the country. By 1998, Chinese and Indians were managing about one-quarter of America's Silicon Valley's high technology businesses. Often foreigners see themselves as Americans and the various strong communities in the United States such as the Indian, Chinese, and African convey positive information about the United States to their home countries which significantly boosts the United States image in the global arena (Nye, 2004, p. 58). The efficacy of American soft power in the Americas was evident in Mexico, Brazil and Chile particularly in the 1990's,

\footnotetext{
${ }^{17}$ An interview with South African scholar 1
} 
when individuals who had been trained in American universities held political positions and advocated for free trade across these countries (Khanna, 2009). The financial crisis has, however, had implications for the economic well-being of immigrants in the United States, following the loss of jobs in various sectors of the economy. 


\subsubsection{United States foreign policies}

Foreign policies that are broad and inclusive are usually more attractive to other states than policies that are atomistic and exclusive. Also policies that are embedded in fundamental values such as liberty and equality are attractive to other states. Foreign policy is often a continuation of domestic policies: the American core values such as democracy, free market and federalism are widely promoted and accepted by other countries in the world (Nye, 2004). The dangers faced by America and the world at large in today's world, which include terrorism, nuclear proliferation, climate change and drug trafficking, require the United States to be more assertive in order to find collective solutions to these threats. The promotion of public goods enhances the soft power of the United States if it appears to the international system that the public good is genuinely being pursued. On the other hand, the promotion of the United States sole interests at the expense of other states might jeopardise Washington's soft power.

The United States war on terrorism can be considered in this light. Following the horrific September 11, 2001 attacks in the United States, the international system realised the imperative to fight international terrorism. Washington mobilised the support of the United Nations to fight its war on terrorism in Afghanistan in 2001. Washington could not claim similar support for the 2003 Iraq war but decided unilaterally to invade Iraq. Consequently, the global image of the United States plummeted around the globe. States began to realise the need to form an alliance against an emerging empire. According to Nye (2004a): "since the currency of soft power is attraction based on shared values and the justness and duty of others to contribute to policies consistent with those shared values, multilateral consultations are more likely to generate soft power than mere unilateral assertion of the values" (p. 64). Therefore, it took the multilateral posture of the Barack Obama administration to ameliorate the United States image which had significantly plummeted during Bush's presidency. Tables 4.7 and 4.8 show the ratings of the Obama administration and the United States favourability in selected countries. 
Table 4.7: US favourability ${ }^{18}$

\begin{tabular}{|c|c|c|c|c|c|c|c|c|c|c|c|c|c|}
\hline Country & $\begin{array}{l}1999 / \\
2000\end{array}$ & 2002 & 2003 & 2004 & 2005 & 2006 & 2007 & 2008 & 2009 & 2010 & 2011 & 2012 & 2013 \\
\hline Canada & -- & 72 & 63 & -- & 59 & -- & 55 & -- & 68 & -- & -- & -- & 64 \\
\hline Britain & 83 & 75 & 70 & 58 & 55 & 56 & 51 & 53 & 69 & 65 & 61 & 60 & 58 \\
\hline Germany & 78 & 60 & 45 & 38 & 42 & 37 & 30 & 31 & 64 & 63 & 62 & 52 & 53 \\
\hline Russia & 37 & 61 & 37 & 46 & 52 & 43 & 41 & 46 & 44 & 57 & 56 & 52 & 51 \\
\hline Egypt & -- & -- & -- & -- & -- & 30 & 21 & 22 & 27 & 17 & 20 & 19 & 16 \\
\hline Israel & -- & -- & 78 & -- & -- & -- & 78 & -- & 71 & -- & 72 & -- & 83 \\
\hline China & -- & -- & -- & -- & 42 & 47 & 34 & 41 & 47 & 58 & 44 & 43 & 40 \\
\hline $\begin{array}{l}\text { South } \\
\text { Korea }\end{array}$ & -- & 52 & 46 & -- & -- & -- & 58 & 70 & 78 & 79 & -- & -- & 78 \\
\hline Argentina & -- & 34 & -- & -- & -- & -- & 16 & 22 & 38 & 42 & -- & -- & 41 \\
\hline Brazil & -- & -- & -- & -- & -- & -- & -- & -- & -- & 62 & 62 & 61 & 73 \\
\hline Nigeria & -- & -- & -- & -- & -- & -- & -- & -- & -- & 81 & -- & -- & 69 \\
\hline $\begin{array}{l}\text { South } \\
\text { Africa }\end{array}$ & -- & 65 & -- & -- & -- & -- & -- & 60 & -- & -- & -- & -- & 72 \\
\hline
\end{tabular}

Source: Pew Research Centre, 2013

\footnotetext{
${ }^{18}$ Face to face and telephone interviews with a number of international participants form the sources of data collection.
} 
Table 4.8: Obama positive ratings ${ }^{19}$

\begin{tabular}{|c|c|c|c|c|c|}
\hline Country & 2009 & 2010 & 2011 & 2012 & 2013 \\
\hline Canada & 88 & -- & -- & -- & 81 \\
\hline Germany & 93 & 90 & 88 & 87 & 88 \\
\hline Britain & 86 & 84 & 75 & 80 & 72 \\
\hline Russia & 37 & 41 & 41 & 36 & 29 \\
\hline Israel & 56 & -- & 49 & -- & 61 \\
\hline Japan & 85 & 76 & 81 & 74 & 70 \\
\hline China & 62 & 52 & 44 & 38 & 31 \\
\hline Brazil & -- & 56 & 63 & 68 & 69 \\
\hline Argentina & 61 & 49 & -- & -- & 44 \\
\hline South Africa & -- & -- & -- & -- & 74 \\
\hline Nigeria & -- & 84 & -- & -- & 53 \\
\hline
\end{tabular}

Source: Pew Research Centre, 2013

Table 4.7 generally reveals a decline in the United States global image from 2003 till the end of George Bush administration in 2008. Except in Egypt and China, America's image began to improve with the election of the Obama administration in 2008 as is evident in the table. Table 8 shows that the US global opinion has received a massive boost under President Obama, perhaps due to the foreign policy swing from Bush's unilateralism to Obama's multilateralism. However, some countries, most especially those in the Muslim World such as Pakistan, Egypt, Jordan and Turkey, are still not convinced by Obama's foreign policy. Their opposition stems particularly from the Obama's war on terrorism and its attendant use of drone strikes (Pew Survey, 2012). The Pew Survey further argued that anti-Americanism stems from the United States foreign policy. The American culture and values are still generally admired across the globe. Against this background, Gardels (2005) argued that in today's global politics, there has been the rise of

\footnotetext{
${ }^{19}$ Face to face and telephone interviews across the nations under study form the sources of data collection.
} 
another super power - global public opinion - which opposes the United States foreign policy. According to the Pew Survey (2013):

Respecting individual liberty remains the strong suit of America's image. Even in many nations where opposition to American foreign policy is widespread and overall ratings for the U.S. are low, majorities or pluralities believe individual rights are respected in the U.S. Across the nations surveyed, a median of $70 \%$ say the American government respects the personal freedoms of its people. (p. 1)

In the light of the above, the extent to which the United States foreign policy enjoys positive global public opinion is determined by the degree to which its foreign policy is embedded in democracy, human rights, openness and multilateralism. An arrogant and unilateral foreign policy has the inherent tendency to erode the efficacy of the United States' soft power and consequently diminishes Washington's influence across the globe (Nye, 2002). Having examined the soft power currencies of the United States, it is time to investigate how America soft power translates to actual influence in the world. Therefore, the following sections analyse America's soft power in Africa and the Middle East.

\subsubsection{America's soft power in Africa}

When you look at it and you think that over the course of the next 20/30 years, quarter of the workforce I guess, is going to come from Africa and $60 \%$ of the population under the age of 30 presents us not just with an enormous challenge because we need to provide education, we need to provide opportunity but also it provides us with the chance to define the future and that is what we are trying to do with our programmes. ${ }^{20}$

In recent years, there has been a shift in American foreign policy in Africa from withdrawal to engagement. During the cold war, the importance of Africa was primarily to expand the sphere of influence of the super powers and the desire of America to contain the spread of communism. Therefore, except in few countries of vital economic interests, the United States withdrew from Africa at the end of the cold war because Africa was not viewed as a strategic region to enhance America's global hegemony. Little attention was given to African problems in the American foreign policy. However, there has been a renewed American interest which can be attributed to the September 11 attacks and its subsequent war on terrorism. Washington now realises the need to tilt its policies towards African failing and failed states which are potential breeding grounds for terrorist organisations (Kraxberger, 2005). Another major factor for this policy shift is the growing economic importance of African countries coupled with the new China's inroad to

\footnotetext{
${ }^{20}$ An interview with American bureaucrat 1
} 
Africa. This creates tension in the United States and foreign policy needed to accommodate these realities. Some of these policies are appealing to Africans and consequently boost America's image in the continent.

In spite of the United States' loss of soft power following the war in Iraq in 2003, it appears America retains a good image in the African continent (Hackbarth, 2009). This is evident in the polls of the United States favourability in the world. In a poll, nine of the eleven states with the most positive image of the United States are from Africa. American foreign policy in this region appears to be less arrogant and unilateral (Hackbarth, 2009). In its recent engagement in the continent, the United States has deliberately promoted its soft power in Africa and the resultant effect is the positive perception of the great power in most African countries. African countries view America in the light of its commitment towards the promotion of democracy, human rights, development, business and its fight against HIV/AIDS.The table below shows the perception of America amongst African countries.

Table 4.9: US favourability in Africa ${ }^{21}$

\begin{tabular}{|l|c|c|}
\hline Country & Unfavourable & Favourable \\
\hline Ghana & 9 & 83 \\
\hline Senegal & 5 & 81 \\
\hline Kenya & 14 & 81 \\
\hline Uganda & 9 & 73 \\
\hline South Africa & 20 & 72 \\
\hline Nigeria & 20 & 69 \\
\hline
\end{tabular}

* Figures in percentages. Source: Pew Research Centre, 2013

Table 4.9 clearly shows that America enjoys a positive image in African countries, even in predominant Muslim countries like Senegal and in Nigeria where there Muslim and Christian populations are almost equal. This contradicts the prevailing perception of the United States in other regions in the light of its unpopular policies in Iraq and the Middle East in general (Hackbarth, 2009). Similarly Nye (2004) proposed:

\footnotetext{
${ }^{21}$ Face to face and telephone interviews across the nations under study form the sources of data collection.
} 
On the substance of policy, the Bush administration deserves credit for its efforts to align the United States with the long-term aspirations of poor people in Africa and elsewhere through its Millenium Challenge initiative, which promises to increase aid to countries willing to make reforms, as well as for its efforts to increase resources to combat AIDS and other infectious diseases. Success in implementing those programs will represent a significant investment in American soft power. So also will be the serious promotion of the peace process in the Middle East. (p. 268)

Against this backdrop, the United States has introduced major foreign policy initiatives to boost its soft power efficacy in Africa which include the African Growth and Opportunity Act (AGOA) designed to facilitate trade, the President's Emergency Plan for AIDS Relief (PEPFAR) which aims to counteract the epidemic, the Millennium Challenge Corporation (MCC) which strives for African development and the US Africa Command (AFRICOM) which provides for military engagement.

Therefore, the United States interests in Africa include strategic, humanitarian, economic and security which manifest in places such as Mali, Somalia and in broader sense East Africa, West Africa and indeed the Saharan region. America's trade and investment relationship in Africa is significant and growing. It is also another major source of oil and other resources for the US but it is also a long term potential market for trade and investment in the US. US interests in Africa are multiple. It has an interest like it does in all parts of the world in promoting and sustaining democracy and respect for human rights. That is a bedrock of its approach not only in Africa but to every other part of the world - Middle East, Asia, Latin America and elsewhere but it is not the sum total of America's interests. US highly seeks economic development. The desire to promote economic development and the lifting of living standards explains why the United States and President Obama has had such an active and significant investment in food security, agriculture and livelihood in Africa. America has an interest in helping the wellbeing of African people. Their education and their physical wellbeing which is why the President has built on the initiative that President Bush started with respect to AIDS in Africa known as PEDFAR. ${ }^{22}$

\subsubsection{American foreign policy and political values in Africa}

The African Growth and Opportunity Act was launched by the Clinton administration. The initiative sought to guarantee complete removal of tax on goods that are exported to the United States which used to be heavily taxed. Therefore, the programme objective was to boost America's economic relations with Africa and to facilitate economic growth and development on the continent (Williams, 2013). To be eligible for the programme beneficiaries had to embark on political, economic and social reforms which include, among others, the fight against corruption, adherence to the rule of law, poverty reduction and upholding workers' rights. States that are not making efforts towards the realisation of these conditions risk their chance of remaining in the programme (Hackbarth, 2009). In looking at the impact of AGOA in Africa, Hackbarth (2009) observed:

\footnotetext{
${ }^{22}$ An interview with American bureaucrat 2
} 
Since its inception, AGOA has not only allowed over 98 percent of exports from partner states to enter American markets tariff-free, but has also increased cooperation and coordination between the United States, American businesses, and partner states. The United States made a significant investment with African states for "trade capacity building" programs that provide technical assistance to facilitate AGOA-sponsored trade, knock down trade barriers, develop intra-African commerce, and increase the competitiveness of African firms. The United States also supported increased American business investment in Africa, increasing foreign direct investment by "52 percent from 2001, to \$3.8 billion," and by providing billions of dollars in financing and risk insurance through the Overseas Private Investment Corporation. Finally, the United States has sponsored annual meetings with AGOA partners, labeled "The AGOA Forum," that "institutionalises a high-level dialogue...to foster closer economic ties between the United States and the region. (p. 7)

The Obama administration and some African countries believe that AGOA has been successful and have therefore called for its reauthorisation (Williams, 2013). Its impact on the African working class cannot be overemphasised. As observed by Greg Mills, AGOA has created about 50,000 jobs in the textile industry in Lesotho (cited in Hackbarth, 2009). Similarly, Williams (2013) observed that the Lesotho Government estimated an increase in the number of the work force in manufacturing industry from 19,000 in 1999 to 45,700 in June 2011. As the most sophisticated economy in Africa, South Africa has the highest share of the United States imports under AGOA and it is also a major beneficiary of the Generalised System of Preference (GSP), a programme by the United States which aims to reduce tariffs on more than 4,000 goods (Kabundi, 2009). It also accounts for the most diversified goods exported to the US under AGOA which include vehicles and chemicals. There has been a dramatic rise in America's vehicle import from the AGOA countries (\$289 million in 2001 to nearly \$2 billion in 2012).

Also in 2011 the US total preferential import from South Africa stood at $\$ 3.7$ billion which represented about three-quarters of US total imports from SSA under AGOA/GSP (Williams, 2013). Writing in 2009, Kabundi argued that trade under AGOA has largely profited South Africa in the last six years and it has used its dominant position in the region to negotiate trade agreements between the United States and SADC. South African companies like AngloGold Ashanti, Gold Fields, Harmony Gold, Telkom, Sappi, and Sasol are listed on the New York stock exchange (Kabundi, 2009). Nigeria is one of the largest trading partners of the United States in Africa and as the world's ninth largest producer of crude oil ${ }^{23}$ : it accounts for the largest supply

23 In 2007, the United States imported more crude oil from Africa than the Middle East; it is estimated that, by 2015, oil imports from Africa will account for over 25 percent of the country's energy supply. Africa's new strategic significance to Washington, which had all but disappeared after the cold war, is the critical factor affecting its peaceoperations policy towards the continent. But even now, its engagement is uneven and is driven largely by its preoccupation with terrorism. (Bah \& Aning, 2008, p. 118) 
of oil to the United States of America from Africa. The United States accounts for 44 percent of Nigeria's oil exports and four American companies - Mobil, Chevron, Ashland, and Texaco are drilling in Nigeria. "AGOA has become a cornerstone of US trade and investment policy in Nigeria" and the United States has been the number one advocate of Nigeria's debt forgiveness, provided Nigeria accepts the conditions attached to AGOA (Ikennia, 2013). AGOA, which is embedded with the political values of the United States, has successfully been strengthening Nigeria's economy. Against this backdrop, AGOA could be argued to project America's soft power in Africa because its main objective of enhancing Africa's development is accompanied with American values. In the words of Makwerere and Chipaike (2012):

With the Africa Growth and Opportunity Act providing the much needed artillery in the USA's soft power arsenal in its new cold war efforts, older programmes like the USAID funded projects in much of SSA are being remobilised to add strength to USA's soft power arsenal. (p.?)

Before the launch of AGOA, the United States had no significant policy in Africa apart from the little commitment to economic and humanitarian programmes under the auspices of the United States Agency International Development (USAID) (Makwerere \& Chipaike, 2012). The criteria of eligibility for the AGOA such as adherence to the rule of law and the upholding of worker's rights represent the core American values. In this light, as African countries strive for development under the platform of AGOA, they imbibe the United States values. As rightly argued by Hackbarth (2009), agenda setting is fundamental to the projection of a state's soft power. The setting of the trade agenda in Africa through AGOA, presents the opportunity for America to listen to African interests and opinions; the forum also provides a platform for African countries to view themselves as having a major role to play in the execution of AGOA. The effect of this is the improvement of the United States' image and by extension its soft power efficacy in Africa (Hackbarth, 2009). AGOA's successes may lead to an extension: "I am hopeful before 2015 expires, we will have the AGOA extension completed". ${ }^{24}$

The Obama administration is working diligently with the Congress to extend AGOA in 2015. The United States has worked with a number of African countries who feel strongly that AGOA has brought considerable benefits to Africa by encouraging the production of products that can be sent to the United States duty free. The Obama administration has seen a significant increase

${ }^{24}$ An interview with American bureaucrat 3 
in the level of imports to the United States through AGOA and it has been one of America's success stories in Africa.

Undoubtedly, AGOA is a programme which has the tendency to generate immense soft power for the United States. This is in view of the fact that the United States economic ties engender "sticky power". However, the extent to which AGOA can generate American soft power across the entire continent can be questioned because few African countries benefit from this programme. This implies that AGOA may not be able to win the hearts and minds of the African countries which do not experience its direct impact. The oil imports from relatively few African countries accounts for most of the trade under the platform of AGOA (Hackbarth, 2009). South Africa accounts for most of the non-oil imports from the continent (William, 2013).

In addition, American soft power generated by AGOA can be eroded if American is not seen in the eyes of African countries as genuinely committed towards free trade. Some critics of the programme have argued that while the United States and the other western countries call for free trade, they create tariff barriers and promote the interests of their domestic entrepreneurs through subsidies (Hackbarth, 2009). AGOA is also viewed by some people as an American instrument to further asymmetric economic relations in Africa which largely benefits America rather than eradicates poverty in Africa. This argument appears well-founded when one considers that the oil producing countries account for the largest volume of trade under AGOA. For instance in 2005, the countries that most benefitted from the initiatives were Nigeria (which accounted for more than half of the exports), Angola, Gabon and South Africa (Lee, 2006). It is worthy of note that the first three countries are major oil producers in the region.

The Millennium Challenge Account (MCA) was established in 2004 by the Bush administration to provide aid to poor countries with the objective of reducing global poverty through sustainable economic growth. The administration promised to provide $\$ 5$ billion annually to finance the activities of the programme and indicated that the funding of the programme would not in any way affect other aid programmes (Fox \& Rieffel, 2005). To this end, aid is provided for countries that are doing well in certain governance indicators which include justice, economic freedom, anti-corruption and protection of civil liberties. African countries have signed 10 out of the 18 compacts which accounts for more than $\$ 3.8$ billion and Nigeria is a major beneficiary 
(Ikennia, 2013). Africa's acceptance of this programme perhaps reflects the leeway given to beneficiary governments to determine and be responsible for the development agenda. Against this backdrop,

MCC is a positive stroke for American soft power. As Nye finds, the Bush administration deserves credit for its efforts to align the United States with the long term aspirations of poor people in Africa...through its Millennium Challenge initiative.... Success in implementing these programs will represent a significant investment in American soft power. (cited in Hackbarth, 2013, p. 9).

The emphasis on good governance, human rights and democracy, which have global support, boosts American soft power and when the United States is seen as genuinely promoting these ideas, it increases the efficacy of its soft power. The unique opportunity the programme affords African countries to determine their developmental agenda, rather than be dictated to, also gives a positive projection of the United States as a benign hegemon (Hackbarth, 2013).

The criteria for states to be eligible for the programme limits the number of states that can benefit. By extension this reduces the impact MCA has on the eradication of poverty in Africa and ultimately curtails the reach of MCA soft power. Africa is the continent with the highest level of poverty and it seems to be the continent with the least capacity to cope with this problem. An attempt to reduce the number of African countries that benefit from this programme on the basis of eligibility could prevent MCA from fully reaching its soft power potential. Writing in 2004, Carbone observed that in spite of Uganda's commendable efforts towards the combat of HIV/AIDS, Kenya's remarkable fight against corruption, and Ethiopia's achievement in the burgeoning number of girls enrolling at school, these countries did not qualify according to the MCA. It appears therefore that the aid is being politicised as countries are chosen on the basis of their strategic importance to Washington rather than on merit (Carbone, 2004). This is illustrated by the choice of countries such as Egypt, Jordan, Colombia, Turkey and Russia (Carbone, 2004). This perception has the tendency to significantly erode the MCA soft power. Furthermore, the qualification of a state for an MCA grant does not automatically guarantee the allocation of the grant. For instance, in 2006, 23 countries across the globe had been regarded as eligible for grants but agreements were only signed with eight countries (including three African countries) in this period (Lee, 2006). Again, this has the tendency to dent the efficacy of MCA soft power and gives the general impression that the United States is not genuinely committed to the eradication of poverty in Africa. 
In the realm of security, the United States launched the US African Command (AFRICOM) in 2007, designed to strictly focus on Africa's security. Prior to this period, United States European Command (EUCOM) based in Stuttgart and the US Central Command (CENTCOM) in Florida were responsible for military engagement in Africa. Even though military relations focus on the hard power currencies of a state, the United States sought to use its military presence to improve its soft power profiles (Hackbarth, 2009). This is evidenced by the increasing importance of Africa in global politics. The new scramble for Africa's resources with the attendant incursion of China in this region, the threat to world security such as terrorism, and failed and failing states, among other factors, inform the renewed interest of Washington in this once neglected region. Against this background, AFRICOM does not limit itself to the provision of traditional security to the African countries but also offers humanitarian aid and promotes development (Isike, Uzodike, \& Gilbert, 2008). While activities like the fight against terrorism would exhibit American hard power, other activities like the military training, education programmes and humanitarian aid contribute to American soft power (Hackbarth, 2009).

In contrast to AGOA's appeal, African countries have been suspicious of AFRICOM. Their suspicion is based on the United States activities in Iraq in 2003 and the resulting erosion of the United States soft power and global image. African leaders and citizens seem to doubt that the Command would genuinely promote democracy, economic growth and development rather than the "iraqisation" of Africa (Hackbarth, 2009). To counteract this negative perception, AFRICOM has made huge efforts to boost its image. It has embarked on programmes that directly impact on African governments and people's lives. For instance the African Partnership Station which operates in some African territorial waters and economic zones provides, among other things, security assistance, officers exchange and training and humanitarian relief to African countries. In addition, efforts have been made in terms of public diplomacy to influence the minds and hearts of Africans and persuade them to consider the positive motives of AFRICOM (Hackbarth, 2009). It seems AFRICOM has successfully ameliorated its image in Africa (Hackbarth, 2009).

In Nigeria, AFRICOM is concerned with the fight against the security threat to the economic survival and corporate existence of the Nigerian state. The greatest threat is the terrorist activities of Boko Haram. Boko Haram is a terrorist group which seeks to Islamise and eradicate western civilization in Nigeria and they have used suicide bombings to achieve their objectives (Akinola 
\& Tella, 2013). In 2012, the Nigerian President, Goodluck Jonathan, requested security assistance from the AFRICOM General, Carter Ham, to complement the Nigerian government's efforts to thwart the activities of the Islamist sect. Ham assured Jonathan of police reinforcement on the border between Nigeria and Cameroon to check the illegal importation of arms across this border (Copeland, 2013). AFRICOM is particularly concerned about certain areas in Nigeria: in the north states like Kano, Bornu, Bauchi, Yobe, Plateau and Kaduna (all strongholds of Boko Haram) and southern states like Bayelsa, Rivers and Delta which possess large deposits of crude oil, as well as Lagos, the commercial capital of the country. The primary activities of AFRICOM are therefore geared towards resolving the crisis in these vital and vulnerable areas of the country (Ifeka, 2010).

According to an American bureaucrat, the United States has been working very closely with the government of Nigeria to address the issue of violent extremism in Nigeria and the US has had a number of meetings with the government. The Nigerian government has been encouraged to continue its efforts and the United States is supporting those efforts. Facing extremism requires a multi-faceted approach - one that includes a security or military element as well as a civilian element to deal with the issues that have led people to become more tolerant of Boko Haram. The United States continues to work with the government to prevent Boko Haram from terrorising the people from Northern Nigeria. America takes a multi-faceted approach to the issue of extremism. Washington strongly believes that countries that have strong democracies, countries that respect human rights, countries that provide opportunities for their people, countries that are economically prosperous and create jobs for their people, can resist the threat of extremism. "So we are working together through our policies to address these issues across Africa and I think we have achieved a great deal of success even in Nigeria. We need to continue to build on those successes across Africa so that extremism does not take root." ${ }^{25}$

AFRICOM therefore appears to enjoy the cooperation and support of West and East African countries. For instance, in 2009, eight African countries benefitted from air force training by the Command (Shabbir Deen, 2013). Southern African countries have been generally ambivalent regarding the intentions and activities of AFRICOM. South Africa in particular has been deeply antagonistic towards the command. The South African government openly opposed the

${ }^{25}$ An interview with American bureaucrat 3 
establishment of AFRICOM and has mobilised the Southern African Development Community (SADC) to express their opposition to the combatant command (Esterhuyse, 2008). This attitude may be borne out of the belief that the United States intends to use the command to promote its own interests rather than Africa's interests which ostensibly include counteracting the rise of China, to tap the resources of African countries and to extend its war on terrorism to Africa.

While AFRICOM claims to fight terrorism in Africa, some African countries perceive that this in itself might trigger terrorism in Africa (Plessis, 2013). This perception could be well founded in that terrorist organisations like al-Qaeda not only target civilians and properties in the United States but also America's interests across the globe, as was evident in the 1998 American embassy bombings in Kenya and Tanzania South Africa continues to oppose AFRICOM and though its former leader, General Carter Ham, visited 42 African countries, he was never invited to South Africa none of the AFRICOM leaders has "managed to change South Africa's attitude officially" (Plessis, 2013). Despite its opposition to AFRICOM, South Africa has formed a National Guard partnership with the New York Guard and its Simon's Town Port has often been visited and utilised by the command to coordinate counter-terrorism and other training exercises (including working with nuclear submarines) with the South African navy (Shabbir Deen, 2013).

In view of the major health concern posed by HIV/AIDS in Africa, the American government decided to initiate a programme called the President's Emergency Plan for AIDS relief. which has been welcomed in Africa. In 2003, the Bush administration made a commitment - the largest by one nation to a health programme - to the tune of $\$ 18.8$ billion to fight the epidemic across the globe (Hackbarth, 2009). Retroviral drugs have been given to about 1.4 million patients, testing and counselling has been provided for more than 33 million, 157,000 babies have been delivered free of HIV, more than 100,000 medical personnel have been trained and about 2 billion condoms have been distributed (Hackbarth, 2009). These efforts have contributed to a huge reduction in the incidence of AIDS.

Perhaps we will be able to have the first generation of children born AIDS free as a result of America's efforts. There has been 44 percent increase in the provision of antiroviral drugs. So it is an amazing story and it is a measure of the full engagement of the United States in trying to help Africa to define its own future in the way it wants to, but to give the lift necessary to do that. ${ }^{26}$

\footnotetext{
${ }^{26} \mathrm{An}$ interview with United States bureaucrat 1
} 
Like the Millennium Challenge Corporation (MCC), the programme does not prescribe to recipient states how to combat the disease. States were encouraged to develop their own programmes to fight the epidemic. Hackbarth (2009) argued that the President's Emergency Plan for AIDS Relief (PEPFAR) has been the most important programme in terms of boosting the American image in Africa. Since its launch in 2004, PEPFAR has given more than $\$ 3.4$ billion to assist Nigeria in its effort to tackle the epidemic. Prior to the establishment of PEPFAR, only about 5,000 Nigerians enjoyed the support of the government for the treatment of the disease but with PEPFAR, approximately 90 percent of Nigerians have received support. In 2013 alone, 540,000 people were supported by PEPFAR of the 612,000 people that were on treatment. The table below shows the US disbursement to Nigeria to tackle the disease.

\section{Table 4.10: US support for Nigeria}

\begin{tabular}{|l|l|l|l|l|l|l|l|}
\hline 2004 & 2005 & 2006 & 2007 & 2008 & 2009 & 2010 & 2011 \\
\hline$\$ 70.9$ & $\$ 111.4$ & $\$ 163.3$ & $\$ 304.9$ & $\$ 447.6$ & $\$ 442.3$ & $\$ 459.2$ & $\$ 488.6$ \\
\hline
\end{tabular}

Figures in millions of US dollars

Source: http://www.pepfar.gov/documents/organization/199599.pdf

In South Africa, PEPFAR has collaborated with national, provincial and municipal governments, non-governmental organisations, the academic and private sectors to greatly intensify prevention, care and treatment of HIV/AIDS. To this end, PEPFAR has disbursed over $\$ 4.2$ billion to South Africa in its effort to tackle the disease and over 17 million people have benefited from the PEPFAR funding. PEPFAR is also involved in capacity building with the aim of energising the South African health sector towards the delivery of quality HIV and TB health services. ${ }^{27}$

In 2010, the number of South Africans receiving ARVs through PEPFAR funding and support increased to 910,700 , up from 646,772 individuals in 2009. In 2011, this number rose to over one million people $1,011,353 \ldots$ In large part due to increased access to treatment, South Africa has experienced a significant increase in life expectancy in just six years, from 54 years in 2005 to 60 in 2011. South Africa's rate of infections in infants born to HIV-positive mothers has also declined from 8.0 percent in 2009 to 2.2 percent in 2013 - a significant accomplishment in just four years.

Table 4.11 that follows indicates the PEPFAR financial contributions towards the fight against HIV/AIDS in South Africa.

\footnotetext{
${ }^{27}$ See http://photos.state.gov/libraries/southafrica/917455/nevhulaudzirk/PEPFAR-SA-Fact-2013.pdf
} 
Table 4.11: US support to fight HIV/AIDS in South Africa

\begin{tabular}{|l|l|l|l|l|l|l|l|l|l|}
\hline 2004 & 2005 & 2006 & 2007 & 2008 & 2009 & 2010 & 2011 & 2012 & 2013 \\
\hline 89.3 & 143.4 & 221.6 & 397.8 & 590.9 & 561.3 & 560.4 & 549.1 & 523.7 & 484.0 \\
\hline
\end{tabular}

Figures in millions of US dollars

Source: http://photos.state.gov/libraries/southafrica/917455/nevhulaudzirk/PEPFAR-SA-Fact2013.pdf

The United States benefits in terms of soft power from the implementation of PEPFAR as is illustrated by the global praise for the initiative, the significant boost in the admiration of America in Africa and noticeable support for the executive arm of the United States congress (Nieburg \& Morrison, 2009). Thus, PEPFAR has been the most important American soft power booster in Africa. However, PEPFAR also has its critics, particularly regarding the major requirements set for beneficiaries such as the allocation of one-third of the programme's money for prevention of HIV transmission to abstinence prior to marriage and fidelity. In addition, beneficiaries of the funds are required to pledge against prostitution (Nieburg \& Morrison, 2009). In a sense, the required pledge from the recipients limits these individuals' rights and is seemingly paradoxical in that America is a champion for liberal ideas across the globe. Some American ideas, such as gay rights, are not favoured in certain African countries. Yet the United States vigorously promotes this idea on the continent. Limiting the rights of the beneficiaries of this programme in, for example, prostitution, seems contradictory to the very ideas America promotes. PEPFAR has also been criticised because huge budgetary requirement for the initiative constrains the budget on other important health issues such as reproductive health, water and sanitation (Nieburg \& Morrison, 2009). Similarly, the programme is criticised because it is perceived as overshadowing American policies on other fundamental issues such as the promotion of democracy and the provision of other developmental assistance for agriculture and education in Africa (Cooke \& Morrison, 2009).

To summarise, all these initiatives have contributed to a positive image for America. While the extent of AFRICOM contribution is limited due to the unclear intentions of the programme in some African countries, the economic initiatives of AGOA and MCC are largely being accepted in Africa due to the opportunity they give to African leaders to pursue their developmental agendas in way they feel best for them rather than being dictated to by the United States. 
PEPFAR appears to be the most accepted American initiative and has had a significant impact on the American image due to the sensitivity and deadly nature of HIV/AIDS.

\subsubsection{American cultural exports in Africa}

The effect of the United States cultural presence in Africa cannot be overemphasised. As in other parts of the world, the American culture has significantly penetrated the African continent. American cultural exports include its fast food, music, media, dressing and its general way of life. According to a Nigerian scholar, the US has penetrated the rest of the world with their dollars and language. They have democratised and globalised their political values. The US fast food mentality is evident in Coca-Cola, McDonalds and KFC everywhere. There is evidence of America's cultural presence in every society. Many countries like Nigeria have imbibed America's ghetto culture. People everywhere, sometimes unwittingly, are wearing American flags on their shirts. This is evidence of American cultural imperialism. In the world today Americans also control the major means of mass media - the newspapers, the magazines, internet etc. The rest of the world is bombarded with the American version of history, the American version of events, American interpretation of everything that is going on in the world. "America has a way of using words to send messages. They could talk about the Libyan dictator. If they like Nigeria, they could say the Nigerian administration in order to send signals to their hearers." 28

Taking into consideration American strength and the fact that the main tools of soft power include the mass media, film industry, internet, cultural events, mode of life, exchange programmes, education, music, literature, sport, fast food, national languages and public diplomacy, the United States has incredible potential and advantage over other countries. ${ }^{29}$ The United States entertainment industry is pervasive across African countries. Hollywood is very popular in African societies. Movies like Godfather, Pirates of the Caribbean, Lord of the Rings, $\mathrm{X}$ Men and Blood Diamond have attracted huge audiences of African people. Hollywood movies are widely shown on African televisions and are very prominent in South Africa. ${ }^{30}$ American music is also very popular in Africa. Artists like Jay Z, Beyonce, Rihana, Neyo, Pharell Williams have massive numbers of follower on the African continent. It is common for young African

\footnotetext{
${ }^{28}$ An interview with Nigerian scholar 2

${ }^{29}$ An interview with Nigerian scholar 1

${ }^{30}$ An interview with South African scholar 2
} 
boys to even dress and act like these popular artists. Concerts by popular American artists held in Africa usually attract enormous audiences.

The American tertiary institutions have attracted vast numbers of African students. Perhaps Partly, this could be due to the high standards of American universities as evident in their dominance in world university rankings. Another possible factor that contributes to the attraction of American universities in the eyes of African students is the wide perception of opportunities available in the United States after the completion of their studies.

\begin{abstract}
I think that for every 10 Nigerian students who are confronted with the option of choosing American and Chinese universities, eight of them would opt for the United States. The United States is seen as the land of opportunities. Someone can be the son of an immigrant in the United States and ten, fifteen, twenty, thirty years down the line becomes the President of the United States. There are so many Nigerians who work in NASA. There are so many Nigerians who work in top Secret Services in the United States. There are over 10,000 Nigerians PhDs in nuclear physics. PhDs in the most specialised branches of science. ${ }^{31}$ With 7,316 students, Nigeria ranks number 19 in the top countries with the highest level of international students in American universities. There is a reason elites around the world remain eager to send their fortunes, and often their families, to the United States. ${ }^{32}$
\end{abstract}

American multinational corporations are widely visible on the African continent most especially in the economically vibrant countries. In South Africa, the United States has over 400 multinational corporations in various sectors of the economy that range from aerospace, agribusiness, apparel and textile, automotive, chemical, construction and mining, education, electricity, electronics and telecommunications, financial, food and beverage, household and consumer goods, industrial equipment and machinery, information system and services, IT and computer, management consulting, marketing service, medical, paper and printing, personal hygiene, petroleum, pharmaceuticals, press contacts, service, state trade offices and agencies, and transportation. ${ }^{33}$ As evident in the sectors mentioned, the American multinational organisations do not limit themselves to the major sectors of the South African economy such as construction and mining, automotive, electronics and telecommunications and petroleum, but also the less important sectors like household and consumer goods, press contacts and service.

To summarise, Africa sees the US as a place of shared cultural affinity especially with the African American community. People can easily communicate in English. A Nigerian scholar observed that the US culture is dominant in Africa and is likely to remain so for a very long time

\footnotetext{
${ }^{31}$ An interview with Nigerian scholar 3

${ }^{32}$ An interview with Nigerian scholar 1

${ }^{33}$ See www.efreeport.com/DisplayFile.aspx?nm=TDOC\&DOCID=88
} 
"not necessarily because the US is doing things right, not necessarily because the US is carrying itself in a manner that the rest of the world like." 34 There are hardly any African countries that do not have American cultural objects like McDonalds and KFC. They are extremely popular in South Africa. In this sense, American soft power is very successful in Africa. ${ }^{35}$

\subsubsection{United States soft power in the Middle East}

The strategic importance of the Middle East undoubtedly stems from the abundance of oil in the region. The region preposterously enjoys huge deposit of oil which is arguably the most importance resource in the world. Against this background, Chomsky and Achcar opine that:

If the Middle East did not have the major energy reserves of the world, then policymakers today would not care much more about it than they do about Antarctica. It has been known since the early twentieth century, when the world economy shifted to oil, that the largest and most accessible supply of energy resources is located in the Middle East. (p. 53).

Even though, the United States only emerged as a global power after World War II, it had established huge influence in the Middle East prior to this period. America wanted to control Middle Eastern oil and therefore competed with other powers like Britain, Netherland and France. During the Second World War there was a fight between the United States and Britain over the control of Saudi Arabia (Chomsky \& Achcar, 2007). Gradually, the United States emerged as the dominant great power in this region. After World War II, Britain was partnered with the United States in the oil rich region but its influence in the Middle East eroded gradually and the United States emerged as the most important power in the region (Chomsky \& Achcar, 2007). It is worthy to note that the United States does not rely heavily on Middle Eastern oil. However, the control of this region's oil boosts American influence across the world. Indeed, American policy makers have always understood that an important way to maintain United States global dominance is to control the sources of oil of their partners (such as the European Union and Japan) and competitors or potential rivals (such as China) (Chomsky \& Achcar, 2007).

The Arab perception of the United States has been varied. More than six decades ago when the United States incursion into the Middle East was relatively new, the Arab countries had a very positive view of the United States. France and Britain were despised for their colonial

\footnotetext{
${ }^{34}$ An interview with Nigerian scholar 3

${ }^{35}$ An interview with South African scholar 1
} 
administration. With the United States' presence and involvement in Middle Eastern affairs, there has been a pendulum swing between periods of severe tension and periods of cordial relations. However, in today's world there is an intense anti-Americanism, despite the fact that some aspects of American values are still appreciated. America shifted more attention onto the Arab countries after the 9/11 attacks and it did not take long for Washington to realise that it was being highly criticised across the Muslim world. The question that then followed in the mind of Washington policy makers and American citizens was "why do they hate us?"

To this end, it becomes pertinent to examine the reason behind the recent antagonistic Arab attitudes towards the United States. A number of polls such as the Gallup and Pew Survey and a plethora of scholars have revealed that the Arab countries admire United States science and technology, some aspects of American values and culture but they strongly oppose American foreign policy in the Arab World. This position appears to be valid particularly when one considers the dwindling American image in the immediate period after the war on terrorism in Afghanistan and Iraq. It is also worth noting that one of the main grievances of al-Qaeda is the United States policies in Muslim lands. In other words, the recent anti-Americanisms in the Muslim world primarily stem from American foreign policy posture in the Middle East and what is considered as double standard policies in this region such as America's tendency to accommodate Saudi and Egyptian authoritarianism, a position contrary to Washington's political values. The table below illustrates the Arab view of the United States.

Table 4.12: US favourability in the Middle East

\begin{tabular}{|l|l|l|}
\hline Country & Unfavourability & Favourability \\
\hline Israel & 16 & 83 \\
\hline Lebanon & 53 & 47 \\
\hline Tunisia & 41 & 42 \\
\hline Turkey & 70 & 21 \\
\hline Palestine territory & 79 & 16 \\
\hline Egypt & 81 & 16 \\
\hline Jordan & 85 & 14 \\
\hline
\end{tabular}

* Figures in percentages

Source: Pew Research Centre (2013)

Table 12 clearly shows a negative view of the United States in the Middle East. The negative perception is as high as 70 percent and above in Tunisia and Turkey and more than 80 percent in 
Egypt and Jordan. The US maintained a very strong relationship with Egypt, particularly under the Hosni Mubarak regime, yet it does not have a positive image in this country. It is also worth noting that the negative perception of the United States in Egypt had existed even before the overthrow of the United States backed Hosni Mubarak regime (Pew Research Centre, 2013). Against this background, in analysing the 2004 Zogby international poll of six Middle Eastern countries (Saudi Arabia, Jordan, Morocco, Lebanon, Egypt and the United Arab Emirates), Rugh (2006) argued that the general opinion of these countries towards the United States was highly unfavourable. The United States undoubtedly has close ties with all these countries, yet there is extremely negative perception of the United States. The unfavourable ratings of the United States in Egypt and Saudi Arabia were as high as 98 percent and 94 percent respectively, and in Morocco, the UAE, Jordan and Lebanon figures were 88 percent, 73 percent and 69 percent in that order.

However, Israel's perception of the United States is in sharp contrast with the other countries. As evident in the table, $83 \%$ of Israelis have a positive perception of the United States. The survey also reveals that America garners its positive image largely from the Jewish community which stands at 90 percent. This is in sharp contrast with the Arab community which accounts for 42 percent (Pew Research Centre, 2013).

\subsubsection{American political values}

While polls have depicted intense anti-Americanism across the Middle East, they have also shown that the hostility to America does not reflect Middle East rejection of American core political values. Democracy and freedom are values widely appreciated among the Middle Eastern population. What angers the Middle Eastern people is the United States apparent double standards regarding the issue of democracy in the region. United States preaches the gospel of democracy in the Middle East and criticises the governments of countries like Iran and Iraq. Yet the United States' close allies in this region, such as Egypt, under Hosni Mubarak, and Saudi Arabia are authoritarian regimes. This creates the impression that the United States only promotes democracy in countries where democracy promotes its economic and strategic interests and associates with authoritarian regimes that further its interest. Egypt and Saudi Arabia maintain the stability in the region, provide the United States with military bases and airspace and guarantee the United States access to oil (Meyer, 2003) In Egypt, under the Hosni Mubarak 
regime, the United States put enormous pressure on Mubarak to allow more political participation by citizens in the country. When Mubarak was able to convince Bush's administration that more political participation would result in the emergence of the Muslim brotherhood - an Islamist fundamentalist group - as the ruling elites, the United States changed its stance (Chomsky \& Achcar, 2007). The driving force appeared to be linked to economic interests rather than democracy. Against this background, Chomsky and Achcar (2007) were of the opinion that:

In the case of Islamic fundamentalism, by any criterion one wants to use, it is obvious that by far the most fundamentalist Islamic state on earth is the Saudi Kingdom. It is the most obscurantist, the most reactionary, and the most oppressive of women. The treatment of women there is absolutely appalling. When you compare the Saudi Kingdom to the Islamic Republic of Iran, Iran looks like a beacon of women's emancipation. I am not kidding. That is in relative terms, of course. By the standard of women's emancipation, democracy, or whatever social value of modernity you want to take into consideration, Iran would rank much higher than the Saudi Kingdom. And yet, the country that the United States vilifies as fanatically religious is Iran, whereas the Saudi dynasty are "our friends." And courted friends, at that. (p. 35)

The double standards of the United States make it difficult for the United States to successfully wield its soft power currency in the Middle East. The most important historical cause of the Middle East opposition to the United States has been its support for authoritarian regimes which do not embrace democracy and freedom. Of course, this is complicated by the Israel-Palestinian conflict which the United States has been struggling to resolve and the war on terrorism in the Middle Eastern countries of Afghanistan and Iraq (Amr, 2004). However, the Middle Eastern countries remain greatly attracted to the American political values, education and technology. This attraction could be traced to the historical penetration of America in this region. About a century ago, the Middle Eastern countries had a positive perception of Washington and they preferred the American values to the values of their European colonial masters. In the 1800s, the American missionaries founded some of the most reputable institutions in the region such as the American University of Cairo, the American College of Persia, the Robert College of Istanbul and the American University of Beirut. These institutions were popular and successful in introducing American culture and political values in the region (Amr, 2004). Today antiAmericanism has grown in the Middle Eastern countries. This stems from Washington's foreign policies which are viewed to be arrogant, supportive of Israel and unilateral. The following section focuses on this issue. 


\subsubsection{American foreign policies in the Middle East}

The major driving dynamics of the United States foreign policy in the Middle East are oil and Israel and this is a reality that is clear to the Arab countries. Israel is seen as an occupier of Arab lands and a country that should be wiped off the Middle East map and United States foreign policy is seen as biased towards Israel. It is clear, therefore, why the Arab world has a negative perception of the United States. Middle Eastern anti-Americanism is occasionally the cause of violent reaction from fundamentalist groups such as the attacks on the World Trade Centre in 1993, American military personnel in Saudi Arabia in 1995 and 1996, American embassies in Nairobi and Dar es Salaam, the USS Cole in 2000 and the World Trade Centre and Pentagon in 2001 (Meyer, 2003).

Beyond oil and Israel as sources of American foreign policy in the Middle East that anger Middle Eastern citizens, other issues include Washington's half-hearted promotion of democracy (the United States seems to promote democracy in countries where democracy guarantees its economic and strategic interests and downplay democracy in countries where democracy may threaten those interests); the war on terrorism and drone strikes in Muslim lands; the perceived American biased role in the Israel-Palestinian conflict in favour of Israel; and theAmerican military presence in Muslim lands, most especially in Saudi Arabia which is considered the holy land of Muslims. The United States' relations with Saudi Arabia have resulted in Arab anger and criticism of the United States and the Saudi regime. The anger is sometimes expressed through violence as was evident in the 1995 and 1996 bombing of American forces in Saudi Arabia (Meyer, 2003).

Accordingly, American foreign policy in this region is a major source of anti-Americanism. Anti-Americanism, which largely emerged from Washington's foreign policy, is a political mindset that has become a buzzword among keen observers of international politics across the world. However, it has been widely expressed by the Muslims in the Middle Eastern countries in recent times (Baxter \& Akbarzadeh, 2008). "US soft power in the Middle East is limited by opposition to US foreign policy: people in the region admire US culture, science and technology, and democracy, but not American foreign policy." 36 According to Nye (2004a), when a state embarks on policies that are perceived by other states to be inclusive, multilateral and broad,

\footnotetext{
${ }^{36}$ An interview with American Scholar 1
} 
such a state effortlessly generates soft power. On the other hand, foreign policies that are perceived to be unilateral, arrogant and selfish in the eyes of others diminish the efficacy of a state's soft power. American engagement in the Middle East is perceived to be unilateral and arrogant. The unilateral position is illustrated by its war on terrorism in Iraq and its continual drone strikes in the Middle East. America's blatant defence of Israel, despite the plight of Palestine, is perceived as arrogant by many Arabs, as are the air strikes on Libya, Sudan and Iraq which caused the deaths of many Muslim Middle Eastern civilians (Abdallah, 2003). Similarly, United States economic sanctions on Iraq, Syria, Libya and Sudan and the torture of Arab prisoners in Guantanamo Bay and Abu Ghraib are viewed as unduly aggressive (Abdallah, 2003). Nye (2004a, p.121) observed that the answer to the question "why do they hate us?" lies in the fact that "many Arabs feared, misunderstood, and opposed American policies, but nonetheless admired some aspects of American culture".

Realising the need to improve the American image in the Middle East, which has plummeted over the years most especially after the launch of the war of terrorism, the United States government has sought to boost its soft power through two major initiatives: the mass media and policies. The mass media is fundamental to setting the agenda by influencing people's perception and attitudes in a given society. The Bush administration was convinced that one of the factors that strongly contributed to anti-Americanism was the Arab media. For instance, the former secretary of state, Donald Rumsfeld, accused Al-Jazeera for promoting anti-Americanism in the Middle East after the satellite television station broadcasted the beheading of Iraqi hostages. Similarly in his 2004 State of the Union address, President George W Bush argued that the Arab television stations triggered recent anti-Americanism by projecting news and images that produce such a reaction among the Arab people (Baylouny, 2005). The United States established media outlets like Radio Sawa, al Hurra television and Hi magazine with aim of portraying the United States in a positive light and influencing the perception of the Arab world about Washington. Radio Sawa was established in 2002 targeting the Arab youth and it has enjoyed wide coverage in the Arab world. Its programmes are broadcasted in FM channels in more than 12 countries in the Arab world which, among others, include Abu Dhabi, Amman, Baghdad, Casablanca, Djibouti, Doha, Erbil, Jerusalem, Kuwait, Manama, Rabat and Sulimaniyah (Amr, 2004). Its popularity stems from its airing of both Western and Arab music, the absence of 
commercials and brief news which is aired twice in an hour (Amr, 2004). Amr (2004) observed that:

Radio Sawa listeners are more likely to have more favorable attitudes towards the United States in all three countries. In Jordan, Radio Sawa listeners had a 37 percent favourable attitude towards the United States as compared to 22 percent of non-listeners. In Kuwait, the percentages were 49 and 54, respectively. And in the UAE, the percentages were 42 and 57, respectively. However, it is unclear whether Radio Sawa caused listeners to be more favorable towards the United States or if more favorable listeners chose Radio Sawa. (Amr, 2004, p.33)

The television station of Alhurra was established in 2004 with the primary objective to promote democracy and freedom and counteract extremism and violence in the region. Above all the aim was to boost the American image in the Middle East. Like Radio Sawa, the primary target of Alhurra is the youth who will be in charge in the near future. Alhurra operates in Jordan, Iraq and Egypt. News broadcasted on this television station usually takes an American perspective. There is wide coverage of statements and interviews of American officials, while speeches of American presidents and close officials are also frequently broadcasted. Often a single news item reflects a different standpoint when broadcast by Alhurra and Arab stations. While the Arab television station reflects the Arab perspective, Alhurra promotes the American view of this event. This television station, as one would expect, is also sympathetic to Israel (Baylouny, 2005). Unlike the success recorded by Radio Sawa in terms of the extent of penetration of the Middle Eastern countries, Alhurra has struggled to have a meaningful influence on the Arab population. One major reason for this is stiff competition (Rugh, 2004). Unlike the limited choice of radio channels, there are many popular television stations for Arab citizens.

Hi Magazine is a monthly magazine launched in 2003. It publishes articles on issues revolving around Arab-American life in Arabic. The magazine provides an avenue for readers to give feedback on the articles read in the magazine. This enables Arab citizens to ask questions on American society and culture and also to seek clarity on issues which seem obscure regarding the American way of life (Amr, 2004). In an area where there is limited access to internet, the magazine is a useful tool for promoting American ideas. In addition to the media efforts in the Middle East, a major initiative of the American government to win the minds and hearts of the Middle Eastern population is the Middle East Partnership Initiative.

The Middle East Partnership Initiative (MEPI) was launched in 2002 with initial funding of \$29 million. The programme objective was to promote freedom and peace in the Middle East with 
the hope that the success of the initiative would guarantee American security. No doubt American security is threatened by the anti-Americanism in the Middle East which leads to violent attacks on American interests by extremists in this region. Given that the Middle Eastern population has witnessed the raw display of American hard power as evident in the war in Iraq and Afghanistan and the continued drone strikes in Pakistan and other Muslim countries, MEPI serves as a tool to promote the soft power currencies of the United States involving foreign aid, trade, education and democratisation. MEPI has a four-point agenda which it strives to achieve in the Middle East. This includes political reform, economic reform, educational reform and women's empowerment (Sharp, 2005). Washington strongly believes that these various reforms would significantly contribute towards the reduction of extremism in the region because the socio-economic condition of an individual may influence his predisposition towards extremism (Akinola \& Tella, 2013). In this light, US economic aid in this programme is tied to economic and political reforms in the region. Some success has been evident with programme beneficiaries embracing elements of democratisation such as the establishment of parliaments and opposition political parties to contest in national elections. However, MEPI has little influence in many Arab countries like Egypt and Saudi Arabia (Sharp, 2005).

In the political arena, MEPI has funded voter registration programmes in Yemen, judicial reform seminars in Oman and Bahrain, and training sessions for female candidates for parliament in Morocco. In the economic sphere, the programme has funded commercial law initiatives, debt reform, and the development of information technology infrastructures in Algeria, Tunisia, and Morocco. In addition, MEPI hopes to help fund retraining programmes for Moroccan farmers who have suffered financial hardship as a result of the US-Moroccan free trade agreement. The initiative also works with the US Department of Commerce to provide internships in American companies for young professionals and to provide training to women entrepreneurs from the Middle East. In the realm of education reform and assistance, the Middle East Partnership Initiative has a pilot programme in Yemen to promote women's literacy, as well as plans to develop greater access to the internet for rural populations. In 2003, 26 students across the Middle Eastern countries who possessed leadership qualities, were provided with the opportunity to participate in various programmes in the United States geared towards learning American politics, history and culture (Amr, 2004). MEPI also funds teacher training programmes at primary and secondary school levels (Sharp, 2005: 5). 
Having examined the composition of the American power, both in terms of its soft and hard currencies, an investigation of the debate around the United States decline will follow.

\subsection{Is the United States in decline?}

Many scholars and observers of international relations have claimed recently that the United States is in decline. This is not a new idea. In the latter part of the cold war period, with the implosion of the USSR, the United States emerged as the sole super power. Debate on American decline has oscillated from American decline in 1980s to American unipolarity in 1990s, to an American empire in 2000s and the rise of decline again in today's world (Starrs, 2013). Therefore, it is worthy to consider what Cox (2007) has labelled the rise, the fall and the rise once again of the American decline debate.

The difficulties encountered by America between the 1960s and 1980s triggered the rise of the declinists. ${ }^{37}$ In the 1960s, Western Europe and Japan enjoyed massive economic recovery following the economic ruins of World War II and the rising US balance of payment deficits. Between the 1970s and 1980s, the United States was struck by high inflation, high interest rates, and high rates of unemployment and the burden of the Vietnam War In the same period, America was challenged by the ideological and military prowess of Soviet Union and China and the ascendance of Japan as an economic power (Starrs, 2013; Norrlof, 2010). In this light, there was considerable literature on the decline of American power in this era. This explains why Paul Kennedy in 1988 asserted that Washington was increasingly experiencing "imperial overstretch"

- huge military presence across the globe - and limited economic resources to guarantee this reality (Starrs, 2013). However, in the early 1990s, the United States began to experience an economic boom. Countries that were seen to be catching up with the United States either stagnated or plummeted. The Soviet Union, which had been an ideological and military rival to the United States, suddenly collapsed into 15 countries and the Japanese economy, which had been booming, stagnated. With the emergence of the Clinton administration, the United States economy grew in leaps and bounds and the debate on American decline gradually ebbed away as the United States had no competitors in all realms of power. Thus, the debate on a unipolar moment, reality and durability displaced the declinist debate in this period. This era witnessed

\footnotetext{
${ }^{37}$ The declinists are proponents of American decline.
} 
the United States dominance in all major components of power and by implication the US wielded enormous influence across the globe.

The immediate period after September 112001 terrorist attacks in America highlighted the huge disparity between the status of the United States and the other great powers. Krauthammer (2003) argued that the disparity manifested in three significant ways. Firstly, it ignited the display of the United States military capacity as the United States toppled the Taliban regime in a couple of weeks in Afghanistan. The author further argued that even though the world has always known America for its military prowess, the September 112001 attacks and its aftermath war on terrorism, showed the globe the degree of American military capacity. Secondly, the event showed American resilience. The symbols of its economic and military capabilities as the largest in both spheres were attacked. The entire nation trembled following this incident, aviation ceased to operate and Congress was recessed. However, in a matter of days, the economy and the congress came back to life and the executive arm mobilised the nation towards a war on terrorism. Thirdly, the event provided a platform for the United States to garner the support of other great powers and middle powers in the international system. States that had hitherto been skeptical in their relations with America put their weight behind Washington. Countries like Pakistan, India and Russia offered enormous support to the United States which ranged from diplomatic support to offering of bases and re-direction of foreign policy towards the United States.

It is, however, worthy to note that $9 / 11$ provided an ideological cover for the United States to unleash what had always been on its agenda which is the maintenance of American hegemony in all strategic areas of the world. Iraq under Saddam Hussein had always been seen as a threat to the United States dominance in that region and it was clearly a part of the American agenda to topple the regime even prior to September 11, 2001. This explains why, for instance, there was a debate by the Bush administration over the first country to invade between Iraq and Afghanistan after the horrific incident of 9/11 (Chomsky \& Achcar, 2007, p. 73). However, the post 9/11 American strategy turned out to be a miscalculation and policy failure as it became evident that "America is not as feared or as loved as it was" (Jentleson, 2007). The wars on terrorism in Afghanistan and Iraq not only ignited anti-Americanism in the Islamic world but in the globe, in general, particularly owing to the illegal war in Iraq and the torture and human right violations of 
terrorist suspects in Guantanamo Bay and Abu Ghraib prison. This runs contrary to the American creed and gave the impression that America adopts double standards and promotes its values only when its economic and strategic interests are not in jeopardy.

To summarise, the American war on terrorism turned out to have a massive impact on its image across the globe, and consequently diminished its soft power efficacy. But as rightly pointed out by Nye (2004) and Kurlantzick (2005) there had been gradual erosion of American soft power before September 11 and its attendant war on terrorism. The war on terrorism expedited the loss of soft power. The end of the cold war and the emergence of Washington as the sole super power convinced US policy makers that there was no viable rival to the United States' dominance of the globe. This resulted in a huge reduction in the investment on soft power. For instance, the budget of the United States Information agency had a ten percent cut between 1989 and 1999 and the USIA resources channeled to Indonesia, a country with the largest population of Muslims, was significantly reduced. The cultural and academic exchange programmes were also hugely affected decreasing from 45,000 in 1995 to 29,000 in 2001 (Nye, 2004, p. 17). The funding of these programmes plummeted every year from 1993 to 2002 (Kurlantzick, 2005). After 9/11 anti-Americanism became more apparent and also metamorphosed into new dimensions. Accordingly Kurlantzick (2005) asserted that:

The past four years have transformed this resentment into outright anger. The Iraq War in particular has sharply reduced global acceptance of the legitimacy of America's role in the world - and a number of US actions have aggravated this decline. For example, poorly conceived security measures launched in the wake of the September 11, 2001, terrorist attacks have made it much harder for many foreigners to obtain American student, work, and tourist visas, or to apply for political asylum in the United States. These changes have prompted questions about the idea of America as a land of opportunity and refuge. (p. 421)

Aside from the image decline of the United States that primarily arose as a result of the war on terrorism, an American triggered financial and economic crisis started in 2007. Layne (2012) argued that the crisis was largely responsible for the contemporary debate on American decline and the disappearance of the United States' unipolar status. He further argues that the crisis revealed two fundamental issues: firstly, the shift of economic power houses of the world from West to East and secondly, the weakness of United States economic liberalism.

Layne further argues that although the United States still enjoys dominance in the military sphere, within the next two decades, it will also be challenged here by the rising powers. He 
predicted that the United States will no longer be able to finance its military commitments and by extension its hegemonic posture in the international system as a result of the continuing economic crisis which will provide an opportunity for the rising powers to catch up.

\begin{abstract}
While America is trying to maintain its hegemony but it is doing it in a wrong way. It is being criticised heavily because of the fact that it does not want to abide by the rules and it wants other countries to abide by such international legal rules. The saga of spying on its allies such as Germany is being frowned upon and questioned by its own erstwhile allies. I don't even know whether its policies on combating terrorism are working anymore. It has huge economic problems and the fact that it owes so much debt to China is another factor. Also America infringes on human rights in its activities in Guantanamo Bay and does not want to adhere to the rules of ICC. All these create a negative impression about the United States among other countries. US is still a very powerful state. It wants to be seen as a benevolent hegemon but it is becoming a despised hegemon and that has consequence. ${ }^{38}$
\end{abstract}

The United States decline is largely the result of two significant events in the $21^{\text {st }}$ century: firstly, the September 11, 2001 terrorist attacks on the Pentagon and World Trade Centre and its consequent war on terrorism and the United States' unilateral posture; and secondly, the 2007 financial and economic crisis which started in the United States and subsequently had global impacts. Needless to say the United States hegemony has rested largely on its economic and military prowess. The wars in Afghanistan and Iraq have highlighted the inadequacy of American military strength and the financial crisis has shown the weakness in the United States economy (Xinbo, 2010). Between 1999 and 2001, the United States Gross Domestic Product (GDP) stood at 28 percent of the global GDP. It has however been in relative decline since 2002 vis-avis the rise of the emerging markets most especially China and India. As the crisis revealed, the United States relied on China for its survival during the crisis and the emerging markets were adjusted and survived the crisis more efficiently than the United States (Xinbo, 2010). The American budget deficit has skyrocketed to record levels and in 2011 and the United States witnessed unprecedented downgrading of its government debt triple-A rating by Standard and Poor (Starrs, 2013). The United States percentage of global imports has declined and its share of world's GDP also plummetted given the growth rates of the emerging markets which double or triple the United States' growth rate (Haass, 2008).

It is common knowledge among experts of economies that if a country constantly enjoys a high growth rate, this will have a positive impact on its GDP. On the other hand, a never-ending low growth rate negatively affects a country's GDP. However, it is important that the debate on

\footnotetext{
${ }^{38}$ An interview with South African scholar
} 
American decline is not exaggerated. According to a Nigerian scholar, the American economy has shown resilience over the last four decades. The recent shutdown of the US federal government, the prospect of a default on the country's debt, and the political dysfunction that made the United States seem to lack direction on Syria and forced the cancellation of President Obama's trip to Asia, of American difficulties at home and abroad, and the rapid rise of new powers such as Brazil, India and China, seem to be an indication of the end of American preeminence and the need to prepare for a global order no longer dominated by the United States. However, predicting the decline of the United States is a risky business. In the 1970s and late 1980s, expectations of waning power were followed by periods of geopolitical resurgence. There is good reason to believe that the cycle is recurring today. Despite a gridlock in Washington, America is recovering from the financial crisis and combining enduring strengths with new sources of influence. In addition, emerging and contending powers are running into difficulties of their own. Taken together, these developments are ushering in a new era of American strategic advantage. ${ }^{39}$

We have seen erroneous predictions of American decline before. In the 1970s, the combination of high inflation, high interest rates, high unemployment, the Vietnam War, political and military challenges from China and the Soviet Union, and the economic rise of Japan led to eerily similar forecasts. Pessimists then, as today, underestimated the longevity of American power. (Norrlof, 2010, p.3)

Similarly Nye (2012, p. 215) claimed that Americans have always estimated their power inappropriately: "After Sputnik, the Soviets were 10 feet tall; in the 1980s, it was the Japanese. Now it is the Chinese". The United States' failure in its war in Afghanistan and Iraq should not be totally considered as a sign of total decline. In the immediate period after the cold war, the United States' dominance was unrivalled, both in terms of economic resources and military capability - it was the sole state with a nuclear arsenal. Yet it was unable to prevent China from embracing communism, completely lost the Vietnam War and could not overthrow the Castro regime after several attempts to dislodge the former President of Cuba (Nye, 2012). Against this background, Nye (2012) distinguished between relative decline and absolute decline. Absolute decline refers to complete decay of a great power and relative decline refers to the relative rise of other great powers in comparison to the dominant power. In this light, the Roman empire

\footnotetext{
${ }^{39}$ An interview with Nigerian scholar 1
} 
experienced absolute decline, while Britain witnessed relative decline in relation to the rise of other great powers like the United States and Germany.

Thus the debate on American decline must be contextualised against the relative rise of other great powers like China, India and Brazil and should not be seen as simply the decay or collapse of the United States. Similarly Serfaty (2011) asserted that the emergence of the United States as the dominant power in the international system in the $20^{\text {th }}$ century was not a function of the rise of America but a result of the collapse of the other great powers. This position appears to be valid in the sense that while the other great powers were fighting in the world wars with all their resources, the United States joined both wars towards the end and largely benefitted from the wars. The effect was that Europe and the great powers suffered devastation from the war while America essentially profited. In the $21^{\text {st }}$ century, the loss of American preeminence may not necessarily be the result of American decline but rather due to the rise of the rest (Serfaty, 2011). To sum up, Jentleson (2007) was of the opinion that the challenges to America's global dominance have manifested in three ways. Firstly, in the economic realm where the challenge emanates from the Asian powers, notably China and India. In the cultural realms, the competition comes from Islam. While anti-Americanism is evident across the globe, the deepest expression of this attitude manifests in the Islamic world and the United States has been struggling to exercise its soft power in this region. In the security realm, the challenge emanates from nuclear proliferation. especially from terrorist organisations like al-Qaeda.

Although the United States has eroded its powers as a result of its unilateralism and economic mismanagement, it still enjoys a measure of dominance in the global arena. Its power is declining somewhat, but much less than many people believe. Indeed, its relative power position could remain roughly where it is today for many years. ${ }^{40}$

\subsection{Conclusion}

The end of the cold war and the implosion of the Soviet Union marked the end of the bipolar order that had characterised international relations since the end of World War II. Consequently the United States emerged as the single super power in the international system. With this status, it wielded enormous influence across the globe such that scholars and keen observers reached the

\footnotetext{
${ }^{40}$ An interview with American scholar 1
} 
consensus that we were witnessing a unipolar era of a super power with influence of no comparison in history. However, in recent times, the unilateral posture, economic downturn of the sole super power and the ascendance of the emerging powers in world politics have brought to fore the debate on the durability of the United States dominance. The realities of the $21^{\text {st }}$ century international politics have stimulated many scholars to argue that the United States has declined in relation to other states. The current argument on the United States decline has been preceded by a similar argument in the 1980s due to the rise of Japan, competition from the Soviet Union and American economic challenges but it turned out that the 1980s declinists were wrong. While America's power and influence, most especially in the realms of world economy and soft power have plummeted in recent years, other powers appear to be gaining in the economic realm. However, the US still remains the sole power with huge advantages in all components of power. It is interesting to observe how the debates on the rise and decline of the United States have unfolded. In three decades, we have witnessed American decline in the 1980s, its rise as a global hegemon in the 1990s and a return to decline in the 2000s. This gives the impression that America's power status in relations to the other great powers is either exaggerated or downplayed.

Therefore, an accurate assessment of America's power in relation to other great powers in the international system will require an evaluation of the other great powers' capability vis-a-vis America's power profiles. This will be explored in the following chapters. 


\section{CHAPTER FIVE}

The Rise of the Rest

\subsection{Introduction}

There seems to be general consensus among scholars of international politics that the $21^{\text {st }}$ century is witnessing a transformation in terms of how power is distributed and how the emerging powers and other middle powers are becoming more assertive in decisions of international and global consequence. In other words, the relative decline of the United States has provided the platform for other powerful states to become more assertive as expected of global players in the international system. According to a Nigerian scholar, for over five hundred years the international order has been shaped by the overwhelming military and economic superiority of the West. But the world is not static. Nothing lasts forever under conditions of globalisation and since the turn of the new century, various scholars have begun to rethink the future shape of the world order. Their conclusions are that the old western world is fast losing its privileged position as new actors, most notably, but not only, in Asia, begin to assert themselves. As a result, one of the greatest power shifts in history is underway with consequences that could prove to be critical to international affairs in the 21 st century. International politics is presently being shaped by a challenging combination of processes of structural change occurring simultaneously and interacting in all manner of complicated ways: financial crisis (a largely Western crisis brought about by neoliberal excess and with economic growth a severe challenge for the US, Japan and nearly all major European economies and a problem at least for the rest of the global economy); shifting economic power (characterised by the rise of countries like China, India, Brazil and others too); and environmental threat (the eventual realisation that climate change is both real and accelerating and questioning of the ongoing viability of traditional notions of economic growth and indeed of society itself). ${ }^{41}$

While the United States has no rival in the military realm, the competition from other states mostly manifests in the economic arena as illustrated by the constant economic growth experienced by these countries and the resilience of their economies during the 2008 financial crisis. Notably among these states are the BRIC countries (Brazil, Russia, India and China).

\footnotetext{
${ }^{41}$ An interview with Nigerian scholar 1
} 
Regarding the waning of American global hegemony and the power shift in global politics, Zakaria (2011) observed that within a particular month in 2008, India and Brazil openly challenged the United States at the Doha trade talks, Russia invaded and annexed parts of Georgia like South Ossetia and Abkhazia and China successfully hosted the most glamorous and expensive Olympic Games ever. Zakaria (2011) further argued that a decade ago, none of those states had the wherewithal to exercise such assertiveness and competence. His observation sheds light on the realities of the $21^{\text {st }}$ century global politics. While the BRIC countries usually act collectively to pursue their interests in the global arena, sometimes they engage in bilateral relations in the pursuit of their agenda, most evident in some of China and Russia's positions at the United Nations Security Council, whereby they maintain stances which are contrary to the interests of the United States and its allies. It is within this context that the Iranian nuclear programme under President Mahmood Ahmadinejad, the Syrian crisis and possibly the Ukrainian crisis can be located. Finally, each country also acts individually when the need arises to promote vital interests.

The unfolding power shift has been tagged to the rise of the rest. It is worthy to note that the most fundamental rise has been in Asia, most especially in China and India. It must also be emphasised that the apparent recent "rise" of Asia is an incorrect assumption: in the mideighteenth century already, Asia accounted for over $50 \%$ of the world's population and products and China was the largest economy. It may be more accurate therefore to describe the "recovery" of Asia which was triggered by Japan, following the Meiji Revolution and manifested in South Korea, Singapore and Malaysia, and currently exemplified by China and India as the contemporary power houses of the global economy (Nye, 2011). Against this backdrop, an Indian scholar observed that: "The past two centuries of Western domination of world history are the exception, not the rule, during two thousand years of global history" (Renard, 2009, p. 9).

Against this background, this chapter seeks to investigate the capabilities of the BRICS countries with the exception of South Africa. ${ }^{42}$ In doing this, it explores both the hard power and soft power resources of these states and identifies China as the most important BRIC state with the

\footnotetext{
${ }^{42}$ While South Africa is also a powerful force in the international arena particularly with the enormous influence it wields within the African continent, it is not a great power like the other BRIC members. Thus, South Africa lags behind in its soft power and hard power currencies in comparison to the other BRIC members and consequently does not wield much influence in the global arena.
} 
capacity to possibly challenge the hegemony of the United States in the international system. To this end, the chapter investigates the degree to which China wields its soft power currencies in Africa and the Middle East. The chapter concludes that the BRIC members' pursuit of individual interests at the expense of collective interests is a major impediment to the objective of the bloc to distort the balance of power and possibly create a true multipolar system.

\section{5,2 BRICs}

The acronym BRIC refers to the states of Brazil, Russia, India and China and was coined by Jim O' Neill, a Goldman Sachs investment and banking firm employee, in 2001 in his paper The World Needs Better Global Economic BRICs. He argued that these countries are emerging powers in the international system and projects that they will significantly shape the future global economy (Skak, 2011). In less than a decade after O'Neill's postulation, BRIC became a political reality as the four countries held their first summit in Russia in 2009. BRIC countries continued to make tremendous progress in their contribution to the global economy. By the end of 2000, the BRIC countries accounted for close to 8 percent of the global economy (O'Neill, 2001, p. 3). In 2009, these countries accounted for 15.5 percent of the world's GDP (Renard, 2009, p. 21). Renard further projected that in 2050, the size of China's nominal GDP would probably double the size of the United States and that of India could equal the size of America (Renard, 2009, p. 22). Renard's observation clearly reinforces the ascendance of the BRIC countries, most especially China and India, in the global economy.

Unlike the Western countries' economies that have generally been affected by stagnant or slow growth rate and also been battered by the financial crisis, the BRIC countries have maintained a high growth rate and have coped better with the financial crisis. In other words, the BRIC economies, most especially the Chinese economy, proved to be more resilient during the crisis. This explains why President Obama has argued that "our generation's Sputnik moment is back" (Skak, 2011, p. 2). While the rise of the rest is not limited to the rise of the BRIC countries, as countries like Mexico, South Korea, Indonesia, Malaysia, Nigeria and South Africa are also rising, the impact of the BRIC countries on global growth dwarfs the significance of these other countries in the world economy.

Countries like China, India, Brazil and even South Africa are emergent powers with influence and followership in this changing system. With this development, the powers of the United States are gradually, but surely declining. It is logical to argue that we now have multiple centres of power in the 
global system. Power is presently shifting, especially in terms of economic power to China, India, South Korea in Asia, to Germany and Russia in Europe and to Brazil in South America. These are therefore, emerging centres of power, reflected in the composition of the BRICs states. ${ }^{43}$

In illustrating the significance of BRICs in the global market, Renard (2009, p. 23) was of the opinion that from 2000 to 2007, the BRIC countries accounted for 27 percent of global growth, more than that of the United States. The states of South Korea, Mexico and Indonesia could only account for 5.5 percent. Similarly, in Global Trends 2025: A Transformed World the National Intelligence Council (2008) projected that between 2040-2050, Brazil, Russia, India and China would equal the G7 share of the World GDP and by 2025 the world's largest economies would be the United States, China, India, Japan, Germany, the United Kingdom, France and Russia, in that order. While Brazil and Russia are large suppliers of natural resources and raw materials, China and India are the world's manufacturing warehouses. No doubt the BRICs form a force in the international system and have been playing active roles in multilateral organisations particularly in the G20 and other initiatives. These countries have shown their capacity to shape the world economy and the structure of power in the international system.

At this point, it is imperative to highlight the rationale for the emergence of BRICs. This is important in that, despite the divergence in the international behaviour between the BRIC countries, they cooperate in some respects in the international system. In this light, the primary objective of the BRIC countries is to distort the western dominated international order in order to have more influence in determining decisions of international consequence. In other words, the BRIC countries seek to put an end to the United States hegemonic position and create a world in which their voices can be heard. The ultimate consequence of this is a tilting of the structure of power from a unipolar order, or illusion of a unipolar system, to a multipolar global framework. This attitude towards the West, especially the United States, is attributed to September 11 terrorist attacks on the United States soil and the subsequent war on terrorism. The United States unilateral posture in the war in Iraq, despite its overwhelming condemnation by other states in the international system and the United Nations, revealed to the BRIC nations the need to balance the power of the United States. The prevalent view among these countries was that if the United States was not tamed, it could assume the role of an empire by using similar force against

\footnotetext{
${ }^{43}$ An interview with a Nigerian bureaucrat
} 
other countries in the international system that are threatening its interests (Laidi, 2011). This explains why the BRIC countries portray themselves as defenders of states' sovereignty.

Undoubtedly, the strength of BRICs to meaningfully shape the structure of power lies in its pursuit of collective interests which manifest in approaches to climate change, world trade negotiations and working towards creating a global financial institution in which their voices can be better heard as the emerging economic power houses in the world (Pant, 2013). They collectively oppose the United States global hegemony and disapprove of the United States projection of its military power around the world as demonstrated by the United States war in Iraq (Pant, 2013). In calling and working towards multipolarity in the international system, they seek to reduce meaningfully the dominance of the United States. They are sovereignty hawks which strive to thwart the United States' attempts to interfere in the internal affairs of other states. They seek to defend the sovereignty of the states in the international system irrespective of regime. They disapprove of international intervention in the Arab states engulfed by revolution (Laidi, 2011). The BRIC countries have strongly opposed the 1998 American air bombardment of Iraq, the 1999 US championed air strikes in Yugoslavia, the 2003 US war on terrorism in Iraq and the 2011 United States led intervention in Libya (Pant, 2013).

The BRIC countries have also made it a policy to speak in one voice in forums such as the World Trade Organisation (WTO) and in global trade negotiations in order to promote their interests which might be contrary to that of the West, particularly the United States (Pant, 2013). The BRIC countries, excluding Russia, formed a bloc in 2009 at the Copenhagen Summit on Climate Change to veto the Western blueprint for environmental protection. This was done in the belief that the Western proposed policy might be to their detriment (Pant, 2013). In July 2014, the BRICS countries established the BRICS development bank which will lend investment money to developing nations, thus assuming a responsibility similar to that of the IMF and World Bank. This clearly shows that the BRICS nations are detaching themselves from the Western dominated international institutions and creating other institutions where they can be more effective in determining global outcomes.

However, the weakness of BRIC lies in the pursuit of individual states' interests in comparison to collective interests. Collectively, they can challenge American dominance in the international 
system. However, individual members of the association relate cordially with the United States on issues of strategic and national significance even when such action jeopardises the collective interests of BRIC (Laidi, 2011, p.7). The emergence of Mrs Lagarde as the successor of Dominique Strauss-Kahn as the head of the IMF is of interest in this regard. Brazil and China especially did not support the candidate from Mexico (who in a sense represented the emerging markets) owing to their national interests. From the perspective of Brazil, the decision was informed by the rivalry between Brazil and Mexico, while China had the option to either support the candidacy of an emerging market or assume the number two IMF position; China opted for the latter (Laidi, 2011). Similarly, like many other states, the BRIC countries have been vocal in the call for reform of the United Nations in order to enhance the effectiveness and efficiency of the institution. However, the call for the reform of the permanent members of the security council to reflect the realities of the $21^{\text {st }}$ century world politics with the possibility of states like India and Brazil becoming permanent members have been frustrated by China and Russia (Pant, 2013). China and Russia value their exclusive status and its attendant influence as permanent members of the Security Council and are not willing to share that status with the other BRIC members. Therefore, rather than China and India, it has been the United States that has promised to support India in its quest for a permanent seat in the Security Council (Pant, 2013).

Russia, like the other BRIC countries, values its membership of this bloc because it serves as a platform in which the resurgent power can engage in multilateralism in the international system particularly in its areas of weakness. However, it seeks to avoid the multilateral approach in areas where it enjoys considerable strength. Thus Russia has not supported the enlargement of the Security Council because it does not want to share the influence that accompanies that status. Moreover, it sees its membership of this exclusive club as one of the fundamental sources of its power aside from its nuclear arsenal (Ladi, 2011). Russia also has considerable interest in ensuring the continual existence of the G8 despite the emergence of the G20 which apparently subsumed the original group (Ladi, 2011).

China sees itself as the major competitor to the United States. Paradoxically, it seeks to have a robust partnership with America, particularly in the realm of trade. To this end, China's values its competitive and cooperative relations with America and endeavours to prevent other states from enjoying similar relations with the United States (Ladi, 2011). Like Russia, China is also 
against the enlargement of the permanent membership of the UN Security Council. While it is not limited to this, this is borne out of the likelihood of India's emergence as one of the new permanent members of the council (Ladi, 2011). With the realisation that Russia and China might thwart Brazil's global ambition most especially its pursuit of the permanent membership of the UN Security Council, Brazil has sought to find alternative ways to promote its interests. For instance, in his address on Brazil's external relations, the head of Brazilian diplomacy conspicuously made reference to IBSA rather than BRIC, even on issues as fundamental to global politics as the Syrian crisis (Ladi, 2011). Similarly the bureaucrat had been reported to have argued that what constitutes Brazil's power and influence is different from that of China and Russia (Ladi, 2011).

The pursuit of individual rather than collective interests is not surprising because these countries have divergent capabilities and as a result each member can influence global outcomes to varying degrees. Brazil is endowed with vast natural resources and huge agricultural land and it is widely considered to be the strongest BRIC soft power. However, it has weak military power. Russia is no doubt a military power and boasts the highest number of nuclear warheads among the nuclear powers but its economy and soft power are not commensurate with its status as a great power. India also possesses considerable military capability with a fast growing economy but has a very antagonistic neighbour in Pakistan. China has a very large and growing economy with relatively strong military power and is also trying to boost its soft power. However, it lacks raw materials and energy (Bertonha, 2010).

Against this background, it is worth assessing the power profile and the international behaviour of each member of the BRIC countries.

\subsection{Brazil: The "B" in BRICs}

From the $20^{\text {th }}$ century, Brazil has pursued an agenda of playing an active role in the international system and by extension influencing international rules as could be expected of a major player in international politics. Brazil's conviction in itself as a big nation destined to play an active role in world affairs, motivates the country to successfully amass its power profiles, most importantly its soft power currencies (such as its territory, population and economic prowess and its democratic institutions) to achieve its foreign policy objectives (DeLima \& Hirst, 2006). 
Brazil has also shown the desire to be more assertive in its region, in the third world and in multilateral agreements. Accordingly, it has worked tirelessly to deepen relations with other emerging powers like China and Russia, to establish South-South relations with countries like India and South Africa, to influence regional and global trade negotiations and its pursuit of the desire to become a permanent member of the United Nations Security Council (De Lima \& Hirst, 2006).

In this light, Brazil enjoys the wherewithal to qualify as a great power. However, unlike other great powers, Brazil is not a military power. Brazil is the only BRIC member not part of the top ten countries with the highest military expenditure and is the only member without a nuclear arsenal. At $\$ 33.1$ billion, Brazil spends only 1.5 percent of its GDP on its military while the United States and Russia spend 4.4 percent of their GDP on their military, and the figures are 2.0 percent and 2.5 percent for China and India, respectively (SIPRI, 2012). It is however, important to highlight that over the years Brazil has made a conscious attempt to boost its military arsenal yet it still lags behind in comparison with other great powers. For instance in 2006, the Brazil military expenditure which amounted to $\$ 13.4$ billion equaled each of Australia, Spain, Canada and Israel's military budgets. At $\$ 20$ billion to $\$ 30$ billion, Italy, South Korea, India, Russia and Germany budgets outstripped Brazil's military efforts. And Brazil's budget was dwarfed by the budgets of Japan, France, China and Britain which spent between $\$ 40$ billion to $\$ 50$ billion each on their military arsenals (Sotero \& Armijo, 2007, p. 45). In analysing the composition of Brazil's military capacity between 2007 and 2008, Bertonha (2010) observed that:

The Army only had second-hand German and American tanks and armored fighting vehicles from the 1970s, of which just 30\% were operational. Its antiaircraft artillery had to be aimed and fired manually and its artillery was obsolete. The Air Force only had light aircraft or some, such as F-5s, therefore out of commission although it was receiving some supersonic Mirage-2000. From its 719 military aircraft, just 267 were operational; the rest were in the repair parks or grounded due to lack of parts. The FAB did not have modern aircraft, attack helicopters or medium range air-to-air missile and its pilots only trained 80 hours per year. In the Navy, less than half of the ships and submarines were operational and few ships were new. The nuclear submarine project was making a slow progress and the few expected acquisitions would not compensate for the units that would become obsolete. The morale of officers and men in the three forces was not good due to the low salaries and low prestige. (p. 116)

It is with the realisation of these shortcomings that the Brazilian government increased spending and increased commitment towards its military forces. Brazil defense expenditure skyrocketed from $\$ 9.23$ billion in 2003 to $\$ 23.9$ billion in 2009 and this has resulted in the acquisition of modern weaponry (Brands, 2010, p. 14). In 2008 alone, Brazil's military budget increased by 50 
percent; its military budget percentage of GDP almost doubled from 1.5 percent to 2.7 percent; there was either the completion or commitment towards the completion of delayed projects such as rockets designed to launch satellites into space and nuclear submarines; there was investment in new armoured fighting vehicles and other sophisticated weapons like the MI-35 Russian attack helicopters; and there were efforts towards capacity building of the armed forces (Bertonha, 2010, p. 117). Despite these efforts Brazil still cannot be regarded as a military power, particularly when its capacity is compared not only to the western powers like the United States, France, Germany and the United Kingdom but also to the other BRIC countries. In 2012, Brazil was ranked $68^{\text {th }}$ in the world in terms of the percentage of GDP spent on military budget. Despite Brazil's minuscule military budget, staff salaries and benefits accounted for over 80 percent of its military expenditure (SIPRI, 2012). Brazil is clearly not a great power that can readily flex its military muscles to promote its strategic interests around the globe.

Despite the fact that Brazil cannot compete with other great powers from a military point of view, it is by far the dominant military power in its region. In terms of its military expenditure, Brazil triples the capacity of Colombia, quadruples the power of Mexico and its military capacity is seven times larger than that of Venezuela and Argentina. Brazil military expenditure now outstrips the spending of all the other Southern American countries combined (Serfaty, 2011, p. 13) Most importantly, Brazil has lived in peace with the countries in its region for more than a century and the last major military engagement of Brazil's armed forces was during World War II. Despite possessing the capacity to produce nuclear weapons, Brazil has renounced the production of a nuclear arsenal since the dawn of democracy (Sotero \& Armijo, 2007).

In the economic realm, Brazil's impressive economic growth can be attributed to the industrialisation and import substitution of the 1940s to 1970 s which resulted in an economic growth of 7.4 percent annually. Between 1968 to 1973, Brazil's GDP increased at an average of 10.59 percent per year (Sotero \& Armijo, 2007). However, this "Brazilian miracle period" was followed by the 1980s macro economic instability and high inflation. Today, Brazil has enjoyed a stable democracy and consistent years of low inflation and conservative macroeconomic management (Martinez-Diaz \& Brainard, 2009, p. 2). Brazil's economy at \$2,253 trillion ranks seventh in the world. Its economic strength is close to the European countries of France and the United Kingdom which rank as fifth and sixth with $\$ 2,613$ trillion and $\$ 2,418$ trillion 
respectively. Brazil's economy is larger than the European economies of Russia and Italy which rank eighth and nineth at $\$ 2,014,775$ trillion and $\$ 2,014,670$ trillion respectively. Brazil's economy is also larger than India's - one of the two economic powerhouses of Asia - which ranks tenth at $\$ 1,841,710$ trillion (World Bank, 2013).

Thus, Brazil's economy is only surpassed by the western countries of the United States, Japan, Germany, France and the United Kingdom and the non-western country of China. This implies that, as the second largest economy, China is the only BRIC member with a stronger economy than Brazil. The implication is that Brazil's economy is robust enough to give the country the status of a great power. Brazil is indisputably a regional hegemon, not only in terms of its military prowess but also in the economic realm. The GDP of its closest rival - Argentina amounts to $\$ 475,502$ billion, Colombia's GDP stands at $\$ 369,606$ billion and Chile's is $\$ 269$, 869 billion (World Bank, 2013). In this light, Brazil's GDP doubles those of the three South American countries. Brazil also has a relative advantage over other BRIC countries owing to its growth rate of 5 percent and its recently discovered oil deposits. In contrast to China, Brazil is a democracy. In contrast to India, the South American hegemon enjoys an absence of ethnic or religious tensions and aggressive neighbours. Unlike Russia, it has a diversified economy and therefore exports commodities other than oil and arms. Furthermore its social environment is conducive for foreign investors (Eldelman, 2010).

The oil discovery, particularly in Santos Basin, projected to have billions of barrels of reserves, should further contribute to the already large economy of Brazil. The share of oil in the country's GDP is projected to be 15 percent by 2025 (NIC, 2008, p. 35). Its endowment of agricultural and natural resources and the attendant global scramble for its products, the efficiency of its economic policies and the success recorded by its major companies have combined to catapult Brazil into an economic force to be reckoned with in the $21^{\text {st }}$ century international economic order. Brazil is a major exporter of automotive products and a major producer of civil aircraft (Amann, 2005). A country that used to be known for its massive foreign debt till the early 2000s has turned around its economy and now has adequate stockpiles of US dollars to dwarf its debt (Moffett, 2008). 
Consequently, Brazil has emerged as a net creditor state with a status that was unprecedented in the history of the South American giant. A country widely known for high levels of inequality has been able to lift millions of its citizens out of poverty and has subsequently created a middle class which accounts for the largest share of the Brazilian population (Moffett, 2008). Despite Brazil's economic muscles in the global economy, the regional hegemon has often been hesitant to flex its economic muscles to achieve desired outcomes. Brazil is reluctant to use its economic prowess as an effective hard power currency and does not use sanctions to promote its interests. Brazil largely embraces the use of non-coercive means to achieve its outcomes.

There are some economic challenges making it difficult for Brazil to realise its maximum potential and optimally influence global outcomes. Among others, the standard of education in Brazil is very low for a country of its status, there is low government spending on research and development and the state of infrastructure in the country is a concern. Martinez-Diaz and Brainard (2009) have claimed that in order to successfully wield its power in the global arena, Brazil has to resolve two major challenges. Firstly, it has to harness the proceeds from its natural resources towards the provision of quality education, adequate infrastructure and modern technology which will create the basis for sustainable growth and development in the country. Secondly, Brazil has to show more commitment towards economic integration and the governance of international markets particularly regarding trade policy. It is important for Brazil to begin to shape global rules and institutions rather than to simply obey rules.

Brazil has relied heavily on its soft powers both within its region and in the world at large. With the changing pattern of power in international politics and the increasing importance of attracting other states rather than coercing them, Brazil's international behaviour appears to be appropriate. Its culture is highly valued across the globe. Its pacifist tradition is widely commended around the world and this has won it respect from other states. As Nye (2004a) rightly pointed out, if a state culture is embedded in values shared by others, it is attractive. Benefitting from a region characterised by peace and absence of great power rivalry, the Brazilian policy towards resolving issues through non-violent means has boosted its standing and image across the world, particularly in the light of regional hegemonic competence in negotiation and diplomacy in international politics (Bertonha, 2010). 
In terms of its popular culture, its football, samba and carnival have always been appealing to other states. Brazil has always been viewed as a soccer nation. It not only enjoys the status of being the country with the highest number of world cup trophies (having won the tournament five times), its entertaining style of football is also appealing to people. The country is also noted for producing football super stars with large numbers of admirers such as the legendary Pele (considered by many as the greatest footballer ever), Romario Ronaldo (a player who holds the record of being the second highest goal scorer in the history of the FIFA World Cup), Ronaldinho and young Neymar (who made a considerable impression at the 2013 FIFA confederation's cup and the 2014 FIFA world cup). Brazil's victory in hosting the FIFA 2014 World Cup and the 2016 Olympic Games demonstrates Brazil's status as a global power in the $21^{\text {st }}$ century. The successful hosting of these events will significantly showcase the culture of Brazil to the world. The Samba is a popular Brazilian music and dance. Together with the Carnival, it serves as symbol of Brazilian culture. The appeal of these cultural symbols to the outside world cannot be overemphasised as is evident in number of foreigners around the world drawn to the annual Brazilian carnival, most especially in cities like Rio de Janiero, Sao Paulo and Salvador. The Carnival is also widely considered to be the most famous annual cultural celebration in the world and the February 2014 party attracted millions of foreigners around the world with Rio de Janiero alone hosting over 900,000 foreigners (The Independent, 2014).

Brazil's pacific and conciliatory posture influences the formulation and execution of its foreign policy. In its international relations Brazil holds in high esteem the values of sovereignty and the peaceful resolution of disputes. Brazil rarely uses its hard power currency to promote its national interests. For instance, despite its economic strength, it has not imposed sanctions on other states. Rather it embraces cooperation in its international relations with other states (Trinkunas, 2014). Brazil plays a major role in many international institutions. In the United Nations, it has been involved in peacekeeping missions such as in Haiti in 2004. Its role in the G20 cannot be overemphasised. It has also made meaningful contributions in the IMF towards resolving the 2008 financial crisis. Within the WTO, Brazil championed the developing countries' opposition to position of the United States and European countries on global trade and it has also played a prominent role in climate change summits (Trinkunas, 2014). This has led to an acceptance of Brazil's leadership in its region and it consequently plays a pivotal role in the region and the globe. Nye (2004) argued that foreign policy that appears to be inclusive, such as promoting 
peace and embracing multilateralism, boosts a state's soft power. Against this backdrop, Brazil non-use of force in its international relations has shown the country in a positive light, most especially among developing countries (Bertonha, 2010).

In comparison to other rising powers such as India and China, Brazil's recent regional security environment is enviably peaceful, at least at the interstate level. "This has diminished Brazil's interest in developing the kinds of military capabilities characteristic of other rising powers. Its history as a developing country has limited its willingness to accept the costs of using economic power through sanctions or aid to induce other states to change their behavior" (Trinkunas, 2014, p. 2). Brazil's positive reputation in the world can also be attributed to its political values. Its apparent consolidated democracy is the envy of other developing countries on the path of democratic consolidation. Among the BRIC countries, only Brazil and India are democracies. Brazil's consistent economic growth, coupled with a strong state and some levels of social inclusion, is admired by developing countries and the developed countries also seek to promote these ideals across the developing world (Trinkunas, 2014). According to the NIC (2008) the Brazilian success story in the political and economic realms provides a model for its region. Other South American countries may emulate Brazil political and economic arrangements following the regional hegemon's impressive performance in these spheres.

Brazil's pacificism could become a weakness, particularly regarding Brazil's relation with the United States on Latin American affairs. America as a global power will want to exercise power in a region as close to it as South America. Brazil, on the contrary, wishes to lessen American influence in the region so as to guarantee itself unrivalled influence in the region. Its renunciation of the use of force weakens its ambition in this region but one way in which Brazil has been able to subtly deter the United States is through the use of soft balancing that significantly manifests in territorial denial (Skak, 2011). In this regard, in 2002, Brazil denied America the use of its aircraft bases and military resources in the Amazon. It also tried to thwart the United States' efforts to establish a military presence in Colombia and explicitly criticised the US war against Iraq in 2003 (Skak, 2011). Similarly, in 2010, Brazil and Turkey signed a nuclear fuel-swap deal with Iran. This agreement was perceived as unpalatable to the United States due to the fact that America had sought to mobilise the international community towards imposing sanctions on Iran over its nuclear programme (Skak, 2011). In addition, Brazil values its membership of Mercosur 
and Unasur because they place the Latin American power house in a better position in its negotiations with America and Europe.

\subsection{Russia: The "R" in BRICS}

Since the emergence of President Vladmir Putin in 2000 in the Russian political space, Moscow has witnessed a new wave of assertiveness in international affairs and has pursued foreign policies that promote Russia as a great power to be reckoned with, most especially through its balance of power politics. To this end, Russia has engaged in military and economic integration in its region and has allied with states that share its world views irrespective of their political values. Under Putin, Russia has also maintained close relations with its old allies from the era of the cold war and the emerging powers, most especially China which seeks to distort the balance of power in the international system in its favour (Hancock, 2007).

Russia can be regarded as a hard power state in view of its military and economic capabilities. In the military realm, Russia's military expenditure amounts to $\$ 90.7$ billion placing the great power as the country with the third highest military spending in the world. This position is only surpassed by the United States and China which rank first and second respectively. Russia's share of the world's military expenditure stands at 5.2 percent. The share of military expenditure in the next countries, United Kingdom, Japan, France, Saudi Arabia, India, Germany, Italy and Brazil is $3.5 \%, 3.4 \%, 3.4 \%, 3.2 \%, 2.6 \%, 2.6 \%, 1.9 \%$, and $1.9 \%$ respectively. Like the United States, Russia spends $4.4 \%$ of its Gross Domestic Product (GDP) to achieve this feat. As the major state that emerged from the defunct Soviet Union, Russia inherited the nuclear stockpile of the Soviet Union and by implication, with 8,500 nuclear warheads, Russia is the strongest nuclear power in the world. Table 5.1 that follows shows the countries with nuclear arsenals and the estimated number of their nuclear warheads. 
Table 5.1: Nuclear warheads of the great powers

\begin{tabular}{|l|l|l|}
\hline Rank & Country & Estimated warheads \\
\hline 1 & Russia & 8,500 \\
\hline 2 & United States & 7,700 \\
\hline 3 & France & 300 \\
\hline 4 & China & 250 \\
\hline 5 & United Kingdom & 225 \\
\hline 6 & Pakistan & 120 \\
\hline 7 & India & 110 \\
\hline 8 & Israel & 80 \\
\hline 9 & North Korea & $<10$ \\
\hline Total & & 17,300 \\
\hline
\end{tabular}

Source: http://www.ploughshares.org/world-nuclear-stockpile-reportcountry

As is evident in the above table, Russia accounts for almost half of the entire world's nuclear warheads which put it in position one and it is closely followed by the United States with 7,700 nuclear warheads. Against this background, the military arsenal of the Russia enables it to flex its muscles most especially within the territories of the former Soviet Union. Thus, Russia has established military bases in countries like Armenia, Georgia, Tajikistan, Belarus, Kyrgyzstan and Moldova. Russia was also able to remove the United States from Uzbekistan, a state which had been strategic for the United States war against the Taliban and al-Qaeda in Afghanistan (Hancock, 2007). In the economic realm, Russia ranks eighth in the world economy with $\$ 2,014,775$ trillion. This gives the impression that the Russian economy is relatively large, particularly when compared with the GDPs of countries like Italy, India, Canada, Australia and Spain.

However, Russia's economy is dwarfed by the economies of the first four largest economies United States, China, Japan and Germany, in that order. Perhaps, the relative strength of the Russian economy explains why the Group of 7 yielded to the demand of Russia in 1997 to enlarge the group to eight (the G8) to include Russia. With this clout, Vladmir Putin has called for an end to the dominance of dollars in the international political economy. It goes without saying that Russia has benefitted significantly from the ever growing energy prices and this has been responsible for the emergence of Russia in the top ten largest economies in the world during Putin's administration. Between 2000 and 2008 Russia enjoyed an average of 7 percent economic growth (Renard, 2009). Sakwa (2008, p. 246) observed that a $\$ 1$ rise in the cost of a 
barrel of petrol is tantamount to a $\$ 1$ billion increase in the Russian government revenue. This provides surplus for the country to address its domestic priorities and foreign policy objectives. The centrality of oil and gas in the revitalisation of Russia's economy has been described by Leo Aron:

One of the two largest oil producers in the world, Russia accounts for 12 percent of global output. Last year it again surpassed Saudi Arabia by pumping almost 10.4 million barrels per day (BPD). It is also one of the world's largest exporters of oil, with nearly 5 million BPD. With the world's largest proven reserves of natural gas, Russia is also the top producer of natural gas, accounting for about 20 percent of the world's total. (2013, p. 1).

Russia relies heavily on its natural resources, most especially its oil and gas. Oil provides over half of the export income and accounts for about 30 percent of Russia's GDP and it is the most important resource responsible for Russia's GDP growth that began in 2000 (Aron, 2013). The danger in the overreliance on oil was evident following the 2008 financial crisis resulted in a drastic reduction in the international price of oil and its attendant contraction of Russia's economy to the tune of 10 percent (Edelman, 2010).

The emergence of a unipolar configuration at the end of the cold war signified an end to the Soviet Union's influence in the globe (Russia and the United States were the major players in international affairs in the cold war bipolar configuration that had shaped global politics for more than four decades). An undisputed global power from 1945 to the mid 1980s, by the late 1980s, the Soviet Union had lost its control of Eastern Europe. In 1991, following the disintegration of the USSR, Russia's influence in Europe dwindled drastically and it was surrounded by weak states. By the dawn of the current millennium, the United States had established a military presence in Uzbekistan and Kyrgyzstan which were entities under USSR (Macfarlane, 2006). According to Turner this reality resulted in "... the form of an acute (and prolonged) case of schizophrenia, with its foreign policy oscillating between allying with the West and allying with the East" (Turner, 2009, p. 162). Russia had thought that it would align with the United States in global dominance.

Russia's influence dwindled under this arrangement as the United States did not provide sufficient funds for post-war recovery and maintained the operation of the North Atlantic Treaty Organization, despite Russia’s opposition (Turner, 2009). Following this disappointment, Russia decided to look towards the East for friendly relations. In this region it found China whose global 
influence had also declined following the end of the cold war. With the demise of Soviet brand of socialism that served as an alternative to western capitalism during the cold war, Russia now embraces the balance of power politics and the principle of state sovereignty as effective mechanisms to tame American global dominance. To this end, Bordachev (2009) noted that, from 1991 to 2008, the United States was confronted with various counter hegemonic coalitions that frustrated Washington's attempt to maintain global dominance and Russia played the most prominent role in these coalitions. Bordachev further highlighted that most notable among these oppositions to America were Russia and China; between 1992 and 1999 they tried to prevent United States from unilaterally determining the decisions made by the Security Council. This has continued into the $21^{\text {st }}$ century and it is within this context that the United States' positions on the Iranian and North Korean nuclear programme, the Syrian and the Crimean crises have been thwarted. Russia and China have either abstained or vetoed resolutions by the United States calling for sanctions on these countries.

Russia appears to be the BRIC member which attaches the most value to its membership of the organisation. This behaviour can be attributed to the role the Soviet Union played during the cold war and Russia still sees itself in that light. It was not surprising that the BRICs had their first summit in Moscow as Russia had championed the establishment of the bloc (Ladi, 2011). Apart from its membership of BRICs, Russia has also engaged in multilateral initiatives to counter the global dominance of America. Such an initiative is the Shanghai Co-operation Organization (SCO), an association that was formed in 2001 with Russia and China as the major players. Russia uses the platform to strengthen its regional and global security. Russia views the organisation as an avenue to maintain strong bilateral ties with China and as a counter hegemonic coalition which seeks to provide an alternative to western institutions and to check the western influence in Central Asia (Wagner, 2012). Russia has engaged in wars and annexation of former Soviet territories when it feels threatened by Western influence in that region. It is within this context that its 2008 war in Georgia and the subsequent annexation of South Ossetia and Abkhazai and the war in Ukraine and the attendant annexation of Crimea, can be located. Apparently, Russia felt threatened by the growing influence of NATO and the IMF in its neighbouring states. 
During the cold war, the Soviet Union wielded its soft power primarily in terms of its political and economical values of socialism across the world. The Soviet brand of socialism provided an alternative to western capitalism which still appeared imperialist to many. Soviet socialism was attractive to some European, Asian, African and Latin American countries. The recorded high growth rate in Soviet's economy in the immediate period after the end of the cold war and the successful launch of Sputnik in 1957 created the impression in the minds and hearts of many that the USSR was "ahead" of the United States. This in turn bolstered the Soviet Union soft power (Nye, 2004). With the collapse of the Soviet Union and its appealing socialist ideology, Russia, particularly under Putin's administration, realised the need to develop and successfully wield other sources of soft power in at least the Commonwealth of Independent CIS states. This did not prove too difficult given the economic growth following Putin's emergence as the President in 2000 and the increasing importance of Russia's gas and oil in this region. The sources of Russian soft power include its goods, which range from natural resources to finished goods, its culture popularised by satellite television, its film industry, its rock music and the perceived availability of jobs for its immediate neighbours (Hill, 2006).

To this end, Russia has attracted millions of people from Central Asia, Caucasus and the other parts of Eurasia in search of greener pastures owing to the visa-free policy implemented by Russia and majority of the CIS states. The Russian official statistics indicate that around 3 million Russian workers are from its immediate region but the number of illegal workers quadruples this figure. Russia has attracted 2.5 million workers from Armenia, 2 million from Ukraine and Azerbaijan, 1 million from Georgia, about 700,000 from Belarus and over 300,000 from Moldova (Cwiek-Karpowicz, 2012, p. 5). Unlike the Soviet Union, Russia has given primacy to its economic power rather than its military strength in its international relations with the states in its region. It has successfully used its economic prowess to persuade its neighbours to agree with its terms regarding the regional policies (Hill, 2006). Russia's dominance in the economies of the CIS is notable. Russia maintains an energy agreement with Turkmenistan which enables Russia to control Turkmenistan's gas until 2028. The Russian state electricity firm is the major supplier of electricity in Georgia. In order to repay a debt of $\$ 40$ million, Armenia gave away its nuclear power station to Russia and a Russian energy company is responsible for Armenia's gas transportation (Tsygankov, 2006). Russian is the dominant language in the region and it has contributed significantly to the attraction of citizens of the post-Soviet Union states. 
Many citizens of the countries in this region, most especially in Ukraine, Belarus and Moldova, understand Russian and it is the language for trade, employment and education in some of the CIS states (Cwiek-Karpowicz, 2012). In illustrating the potential of Russia's soft power, Hill posited that:

If the influx of migrants from surrounding regions continues; if Russian business investment grows in neighboring states; if regional youth continue to watch Russian TV and films and purchase Russian software, CDs and DVDs, and other consumer products; and especially if the heavy hand of Moscow is pulled back and the hand of commerce is extended instead in Russian foreign policy, Russia will achieve the economic and cultural predominance in Eurasia that the United States has in the Americas. (Hill, 2006, p. 342)

In order to counteract the Western influence and the appeal of Western democracy and institutions, Russia has developed its own ideology which emphasises its own brand of democracy, the so-called "sovereign democracy", and it has been vocal in the criticism of Western democracy and way in which it is being promoted across the globe. The Russian "sovereign democracy" promotes limited citizen participation in the political process. According to Popescu (2006) the term emphasises two ideas: sovereignty and Russian values. Sovereignty in this context basically refers to non-interference from the west in the domestic affairs of states, most especially the CIS states. The Russian values are considered democratic values which take into consideration the distinctive historical and domestic realities of Russia and are significantly divergent from the Western conception of democracy. To this end, the "rule of law, protection of minorities, a free press, a viable political opposition, or legally guaranteed property rights are not part of the reality of the sovereign democracy" (Popescu, 2006, p. 1).

The concept of sovereign democracy serves two major purposes: firstly, it provides a democratic cover for Putin's authoritarian administration and subsequently provides domestic legitimacy and prevents international criticism, and secondly, it challenges the universality of Western ideas of democracy and human rights (Popescu, 2006). The Russian government has deliberately promoted policies targeted at the outside world to influence their perception of Kremlin, particularly through the establishment of non-governmental organisations (NGOs). It is within this context that the Russiky Mir Foundation, which was founded in 2007, can be located. The official primary objective of the organisation is to promote the Russian language and culture in general as one of the major civilisations in today's world. However, its operations reveal that it seeks mainly to promote the interests of the Russians living in the CIS states (Cwiek-Karpowicz, 2012). 
The mass media has provided an important avenue through which Kremlin promotes its soft power. Particularly through the internet and television stations, Russia has been able to reach the CIS states and beyond. For instance, in 2005, Russia established Russian Today (RT), a television station that broadcasts in English, Arabic and Spanish in more than 100 countries. Online news outlets like Regnum and Novy Region have also promoted Russian positions in its immediate region. In addition, Russian newspapers like Komsokolskaya Pravda and Argumenty i Fakty have improved on their special editions in the CIS countries and Rossiyskaya Gazete collaborates with popular international newspapers like the Washington Post, Daily Telegraph and Le Figaro for the editing of their monthly report on Russian politics for foreign audiences (Cwiek-Karpowicz, 2012). Most citizens in the CIS prefer the Russian media to the Western media as it is Russian and not English and also because of the historical ties that still bind these states together (Tsygankov, 2006).

It is worth noting that Russia does not significantly wield soft power beyond the CIS states. This may be attributed to its domestic politics which is riddled with corruption, abuse of human rights and authoritarianism. The limitation of its soft power is also a reflection of the minimal spread of the Russian language. Unlike the English language which is widely spoken across the globe, the Russian language is limited in its popularity. Even within the CIS countries, there are aspects of Russian soft power currencies that have plummeted since the 1990s. There has been a huge decline in the number of Russian schools and Russian speakers in the post-Soviet states. The number of Russian-language schools in this region has decreased from 20,000 to 7,000 and the number of students that are taught in Russian has declined from over 5 million to 3.1 million (Filimonov, 2010).

In considering the way in which Russia strives to promote its soft power within its immediate region, one may be tempted to conclude that Russia's main objective is to counteract the influence of the United States and its western partners in its immediate region. As pointed out earlier, this informs why Russia does whatever it can to prevent NATO and IMF in the CIS countries as was evident in Georgia in 2008 and Ukraine in 2014. 


\subsection{India: The "I" in BRICs}

Perhaps the most fundamental development in contemporary international political economy is the ascendance of Asia. Asian countries, particularly China and India, have undoubtedly recovered and are working towards their $18^{\text {th }}$ century status when they accounted for over 50 percent of the world's products. NIC (2008) projects that, by 2025, the GDP of these two Asian giants may outstrip that of other countries aside from the United States and Japan. The observation of India's solid economic performance in the international scene appears to be a recent phenomenon. However, India maintained a six percent growth in its economy annually between 1980 and 2002 and 7.5 percent between 2002 and 2008 which puts India as one of the best performing global economies for 25 years (Das, 2006, p. 2). Similarly, Srinivasan (2006, p. 3716) observed that when one takes into account countries with a minimum of 10 million people, the growth of China and India have arguably been the most remarkable since 1980. He further argued that between 1980 and 1990 the Indian growth rate was 5.7 percent and the five countries whose growth rate outstripped India's in this period were below India between 1990 and 2000 and between 2000 and 2004 as India grew at 6.0 and 6.2 annually in those periods respectively.

India's profile in the international arena stems from its solid economic growth and its democratic achievements. India has consequently seized the opportunity that accompanies such a profile to seek a multipolar order in which it will play an active role in the international system as one of the polar powers (NIC, 2008). India has maintained an average of 5 percent growth annually since the beginning of the $21^{\text {st }}$ century and predictions on the country's long term growth have been positive (Edelman, 2010). Das (2006, p. 2) posited that:

\footnotetext{
The notable thing about India's rise is not that it is new, but that its path has been unique. Rather than adopting the classic Asian strategy-exporting labor-intensive low-priced manufactured goods to the West, India has relied on its domestic market more than exports, consumption more than investment, services more than industry, and high-tech more than low-skilled manufacturing.
}

With a GDP of $\$ 1,841,710$ trillion, India is the third largest economy in Asia behind China and Japan and the tenth largest in the world (World Bank, 2013). It is forecast that it will maintain a 6 percent growth rate for many decades (Renard, 2009). If such an impressive growth rate is actually maintained, India is bound to rise quickly and dramatically in the ranking of the largest economies in the world. India has been able to achieve this feat thanks to its advancement in information technologies and pharmaceuticals (Harris, 2005). In illustrating the significance of 
the IT sector to India's economy, Harris (2005: 19) posited that "in 2003, India had 52 per cent of the global revenues from outsourced IT work and 46 per cent of the employment" and in 2005, well over 400 hundred countries outsourced IT contracts valued more than $\$ 1$ million to India. As companies in states like the United States outsource their work to IT companies, the employment in this sector tilts in favour of India. India is also ahead of China in this sector as India's companies constitute about 40 percent of China's IT exports (Harris, 2005, p. 19). Thus, India's economic success has resulted in hundreds of millions of Indians entering the middle class and has subsequently reduced the level of poverty in the country. In addition, India has now become a major player in international organisations like the ASEAN, the East Asian Summit, the Shangai Cooperation Organisation and the African Union (Mohan, 2006).

In terms of its military strength, India ranks eighth in world's military spending with $\$ 46.1$ billion and only spends 2.5 percent of its GDP to this end. India ranks above the European powers of Germany and Italy which rank nineth and tenth with an expenditure of $\$ 45.8$ billion and $\$ 34.0$ billion respectively. In terms of the size of its armed forces in comparative terms with the world, India ranks second in army, fourth in airforce and fifth in naval force (Shamsi, 2012). In addition, like Russia and China, India is a nuclear power state with an estimated capacity of 110 warheads. It successfully launched its first nuclear bomb in 1974 and has made further advancements in the technology. India has also been procuring sophisticated military arsenals such as nuclear-powered marines, aircraft carriers, long-range combat aircraft and is developing an intercontinental ballistic missile with the capacity to strike beyond 5,000km (Ladwig, 2010).

India's military force is close in numbers to America's military and it has maintained a 13-25 percent growth in its budget annually (Edelman, 2010, p. 49). The Asian country has made efforts to boost its spending on military research and development and has endeavored to modernise its land, navy and air force and equipment. To this end, $\$ 30$ billion was allocated to the air force to procure, among others, aircraft, missiles and the repair of air defense equipment (Keling, Shuib, \& Ajis, 2009, p. 25). Particular attention is given to its navy owing to the strategic importance of the sea in its international trade. Ladwig (2010) observed that in terms of quantity and actual worth, 90 percent and 77 percent of India's international trade respectively, is facilitated by the sea. This makes India a natural naval power and the Asian power is actively involved in the maritime balance of power politics in the Asia-Pacific with the United States, 
China and Japan (Scott, 2007). In this light, \$20 billion was allocated to the navy for the procurement of two airplane carrier tankers, submarines, missiles and surveyor aircrafts (Keling, Shuib, \& Ajis, 2009, p. 25).

According to Mohan (2006) India's grand strategy can be viewed from the prism of three concentric circles. In the first circle which covers its sub-region, India strives for hegemony. In the second circle, which comprises Asia and the Indian Ocean, India endeavours to counter the influence of competing states that may jeopardise its interests. And in the last circle, which embodies the global system, India projects itself as a great player to be reckoned with regarding issues around international politics. Against this backdrop, despite continued United States interest in maintaining a military presence in India, the Asian giant has denied Washington its territory for a military base to further its strategic interests in the region. However, India appears to be the BRIC member with the most sympathetic attitudes towards the United States as was evident in its support of the United States war on terrorism in Afghanistan and in how it has distanced itself from the criticism of the United States war in Iraq (Skak, 2011).

There is no gainsaying the fact that India is a soft power state and this explains why its rise has not been greeted with suspicion like the Chinese ascendancy. India's soft power is visible in South East Asian states owing to a shared culture and traditions (Purushothaman, 2010). India's cultural influence is also visible in other states across the world, like Iran and South Africa, due to the long standing cultural link between India and these countries. India's Bollywood, diaspora, music and art have become widespread across the globe (Purushothaman, 2010). In terms of its culture, India's historical link with states like Iran, Rome and South East Asian states has enabled generational mobility of the Indian culture in those countries. In South East Asia, the Indian culture is visible in temples of Cambodia, Thailand and Indonesia (Purushothaman, 2010). One of India's religions - Buddhism - is practised across the globe and its presence is highly visible in countries such as Sri Lanka, Cambodia, Laos, Thailand, Myanmar, China, Korea, Japan, Vietnam, Singapore, Taiwan and Tibet. The reach of India's yoga cannot be overemphasised. It is widely believed to be efficient for stress relief and is a form of exercise whose reach permeates the Western states (Blarel, 2012). Partly due to huge diasporas across the globe, Indian foods are not only popular within their immediate regions but they are also wellknown in the West and Africa, most especially in the United Kingdom and South Africa. The 
Indian movie industry -Bollywood - is the number one industry in the world in terms of production of films, a position it achieved after outstripping the United State's Hollywood. Indian movies appeal to an international audience and Indian movies such as the "Slumdog millionaire" and the "Three idiots" have shaken the entertainment world in terms of the large audiences and the praise they attracted across the globe. Slumdog Millionaire won eight Oscar awards in 2009. It goes without saying that Bollywood has successfully penetrated Europe, Africa and Asia and the Middle East (Blarel, 2012). Indian soft power is evident in Africa; consider the Bollywood film industry and the Indian food outlets across the continent. ${ }^{44}$ By 2009 , the Indian Council for Cultural Relations (ICCR) had established 22 cultural centres in 19 states; these centres provide other countries with a taste of Indian culture which is promoted by film festivals, book fairs and art events (Wagner, 2010)

In the realm of foreign policy, India's non-violent methods promoted by its charismatic leader, Mahatma Gandhi, in the struggle for independence have always contributed to a positive image of India in the world. India has always tilted towards a multilateral approach in its international relations. As Nye (2004) rightly pointed out, when a state's foreign policy is seen to be inclusive in the eyes of others, such a state amasses or boosts its soft power efficacy. On the other hand, when a state's foreign policy is seen to be unilateral or arrogant, such a state erodes its soft power. India was one of the states that condemned colonisation and global armaments. India stood for the position of the developing states at the level of the United Nations, particularly under the administration of Jawaharlal Nehru (Wagner, 2010). India was a pioneering member of the General Agreement on Tariffs and Trade (GATT) in 1947 and the United Nations Conference on Trade and Development (UNCTAD) and the formation of the non-aligned movement (Wagner, 2010). In 2003, alongside Brazil and South Africa, India formed an international organisation called IBSA Dialogue Forum with the primary objective to promote cooperation among these countries and the developing world at large. In 2009, India, Brazil, Russia, China established BRIC which was later joined by South Africa to distort the international balance of power in their favour against a western dominated order. In the Middle East where both the United States and China do not wield much soft power ${ }^{45}$, India wields some level of soft power owing to India's support for Palestine in the United Nations (Purushothaman,

${ }^{44}$ An interview with South African scholar 1

${ }^{45}$ An interview with American Scholar 2 
2010). In terms of political values, India has gained respect in the world as the largest democracy in the universe and its democracy has been stable and sustainable. India has never experienced military rule since independence (Purushothaman, 2010). The success story of India's democracy has revealed to the developing nations that democracy can indeed function effectively no matter the level of development of a state and irrespective of whether a state is in the western world or not. This can be attributed to India's credible elections since independence and an inclusive system which ensures that even the conventionally marginalised groups participate actively in the art of governance. India's recorded success in its democracy is unprecedented among states that gained independence after World War II (Wagner, 2010). In this light, Bhutan and Nepal's decision to embrace democracy reflects the success recorded by the Indian democracy (Purushothaman, 2010). Democratic states are usually characterised by a high level of citizens' involvement in the decision making process and rule is by the consent of the governed. Therefore, it can be argued that India's democracy boosts the soft power efficacy of this country unlike China which is criticised for its authoritarian style of politics. However, the violation of human rights by the institutions of the state such as the police and the military can tarnish the image India has laboured to build for itself as the largest and respectable democracy in the world. This perhaps explains why the Indian democracy is not viewed by other states as a model to follow despite its accolades (Wagner, 2010).

Given the potential in India for economic strength, cultural richness and democratic values, it is an Asian power with the capacity to influence major issues of the contemporary international politics. India has been able to manage relations with its rivals in its regions (China and Pakistan) and it has become more influential in the Persian Gulf, Asia, the Indian Ocean and Africa in addition to establishing commendable relations with other great powers like the United States (Mohan, 2006). India is an emerging great power especially when one considers India's size and population and the fact that it owns nuclear weapons. India is also emerging as a technological power to be reckoned with. It will not only exert influence in Asia but the rest of the world. ${ }^{46}$

\footnotetext{
${ }^{46}$ An interview with Nigerian scholar 2
} 


\subsection{China: The "C" in BRICs}

The Asian countries in BRICs have drawn more attention than other members owing to the low cost of labour and to efficient governmental policies which have attracted massive manufacturing and service industries to China and India (NIC, 2008). The ascendance of China in particular has implications for the structure of power in the contemporary international political economy. It is apparent that China is the only state with the wherewithal to possibly challenge the dominance of the United States in the international arena. There is a very slow shift away from the US and the US system (US+allies), caused mainly by China's rise and to a lesser degree by the rise of other actors. ${ }^{47}$ The Chinese economy has been projected to equal that of the EU in the next three decades (Renard, 2009: 27). The economic crisis has also revealed the strength of the Chinese economy. China is also rising in the military sphere.

With personnel of over two million, China prides itself with having the largest armed forces in the world. The Asian power has significantly increased its military spending. The Chinese military spending reports show China spent \$42,635 billion in 2006, \$52,064 billion in 2007 and $\$ 61,185$ billion in 2008 on its military (Chen \& Feffer, 2009, p. 49). However, it is widely believed that China does not report its actual expenditure on its military in order to hide its military potential from the outside world. This perhaps explains why the United States Department of Defense provides annual reports on the Chinese military budget. Contrary to the $\$ 61.185$ billion reported by the Chinese in 2008, the United States Department of Defense (DOD) put the figure between $\$ 105$ billion to $\$ 150$ billion (Chen \& Feffer, 2009, p. 52). Nevertheless, China is by far the second highest military spender. At $\$ 166$ billion, China accounts for 9.5 percent in its world share of military expenditure and unlike the United States and Russia, which rank first and third respectively, and which spend 4.45 of their GDP on their military, China spends $2.0 \%$ of its GDP to achieve this feat (SIPRI, 2012). China has been working relentlessly to modernise its military with the primary objective of building the capacity to engage and win wars of short duration within its immediate environment against enemies with sophisticated military hardware. Therefore, China has been investing heavily in the procurement of advanced weapons from foreign countries and the development of military technology at home - which has enabled the Asian powerhouse to develop the capacity to locally produce

\footnotetext{
${ }^{47}$ An interview with American scholar 1
} 
sophisticated weapons like missiles and fighter jets (Chen \& Feffer, 2009). The Asian power is also investing in nuclear armaments primarily by procuring advanced inter-continental ballistic missiles and nuclear-powered ballistic missile submarine (Chen \& Feffer, 2009). China is also spending on an anti-air craft defense system in order to provide an effective shield against the fighter jets and other weaponised aircrafts of hostile states. Finally China has been developing technology for cyber warfare in which the computer networks of enemies are intercepted (Chen \& Feffer, 2009).

China has a very strong economy. Chinese state firms still contribute largely to China's GDP and employ hundreds of millions of its citizens (Harris, 2005). In 2005, Harris argued that several Chinese cities have larger economies than some countries. At $\$ 80$ billion, the Shanghai GDP equals that of Hungary, Chile and Pakistan (Harrris, 2005, p. 10). Since the beginning of the economic reform in 1979, the Chinese economy has grown annually by almost 10 percent and has successfully lifted half a billion people in China out of poverty. China has emerged as an economic powerhouse in the international arena evident in its current status as the largest global manufacturer and the second largest economy (Morrison, 2014, p. 1). With a GDP of over \$8 trillion, China comfortably ranks second in the global economy. Its closest rival - Japan - ranks third with over $\$ 5$ trillion and Germany and France rank fourth and fifth with over $\$ 3$ trillion and $\$ 2$ trillion in that order (World Bank, 20). China's capacity to maintain its impressive growth has generated the prediction of the eventual emergence of China as the largest economy in the world. Not surprisingly, the emergence of China as an economic super power has attracted other countries across the globe to trade with the Asian economic powerhouse and the United States has not been a bystander in this regard. In illustrating the economic relations between China and the United States, Morrison observed:

China's rapid economic growth has led to a substantial increase in bilateral commercial ties with the United States. According to US trade data, total trade between the two countries grew from $\$ 5$ billion in 1980 to an estimated $\$ 562$ billion in 2013. China is currently the United States' second-largest trading partner, its third-largest export market, and its largest source of imports. Many U.S. companies have extensive operations in China in order to sell their products in the booming Chinese market and to take advantage of lower-cost labor for export-oriented manufacturing. These operations have helped some US firms to remain internationally competitive and have supplied US consumers with a variety of low-cost goods. China's large scale purchases of US Treasury securities (which totaled $\$ 1.3$ trillion as of April 2014) have enabled the federal government to fund its budget deficits, which help keep US interest rates relatively low. (2014, p. 1). 
China is the largest trading partner of Japan and South Korea. Countries like Australia, Canada and Brazil have huge investments in China and their multinational companies such as Nippon Steel, BHP Biliton and Rio Tinto have penetrated the Asian country. In addition, China has emerged as one of the largest markets for vehicles. Thus, General Motors, Ford, Chrysler, Toyota, Honda, Hyundai and Volkswagen have factories in China for the production of their various brands (Harris, 2005). The 2008 global economic meltdown disrupted the economic progress of China as its real GDP growth plummeted from 14.2 to 9.6 percent between 2007 and 2008 and further dropped to 9.25 percent in 2009. However, the Chinese government, through its stimulus package and other economic policies, successfully curtailed the impact of the crisis as economic growth stabilised between 2009 and 2011. Despite the efforts of the Chinese government, economic growth has further fallen. China could only record a 7.7\% growth in 2012 and 2013 (Morrison, 2014, pp. 3-4).

There has been massive foreign direct investment in China owing to availability of materials and relatively cheap labour. This has significantly contributed to the economic success story of China primarily in terms of tremendous economic and trade growth. In 2010 over 400,000 foreign invested enterprises (FIEs) were registered in China and they accounted for the employment of 55.2 million workers (Morrison, 2014, p. 11). The relevance of the FIEs in the Chinese economy cannot be overemphasised. In 2013, the Chinese FIEs recorded 47.3 percent and 44.8 percent of China's exports and imports respectively, and between 2002 and 2010, FIEs accounted for 79 percent to 82 percent of China's high tech exports in that order (Morrison, 2014, p. 11). Being the largest producer and consumer of steel, China has attracted some of the largest corporations in the steel industry around the world such as the Luxembourg Arcelor, the Dutch LNM, the German ThyssenKrupp and the South Korean Posco. These corporations have huge investments in China (Harris, 2005). China's hunger for energy has triggered investment abroad, especially in oil and gas. With its growing appetite for energy, China has emerged as one of the largest direct foreign investor (Harris, 2005).

China's core objective was not limited to acquiring economic muscle; military prowess was required to contest the United States in the pursuit of regional hegemony in East Asia (Layne, 2012). This process has been expedited by the 2008 financial crisis. The Chinese perceptions of the United States after the crisis are in a state in decline vis-a-vis the rise of China to a great 
power status and China has continued to wax in confidence following its achievement in recent times. For instance in 2009, the chief of China's Central Bank, Zhou Xiaochuan, called for the creation of an alternative currency to replace the United States dollar hegemony in the international system (Xinbo, 2010). China outstripped the United States as the largest manufacturing state (Layne, 2012). The Great recession has also revealed the resilience of the Chinese economy. Unlike the western countries, China managed to recover from the crisis thanks to its economic model which is characterised by the strong role played by the state in the economy (Xinbo, 2010). The strength of the Chinese model has subsequently emerged as an alternative to western economic liberalism.

Even though the United States is far ahead of China in the military arena, China has been making impressive progress in its military modernisation with the aim of reducing the United States advantage in this realm (Layne, 2012). China's military expenditure has skyrocketed in the last two decades and most especially since the late 1990s, the military spending has risen 25 percent more than the GDP (Edelman, 2010, p. 58). China has been taking the opportunity provided by the relative decline of the United States to strengthen its military and balance the hegemony of the United States in East Asia. Before now, the United States had enjoyed an unchallenged projection of its military power in this region, sometimes to the detriment of China's interests, most especially in Taiwan. The US response to the 1996 Taiwan Strait crisis, the 1999 Kosovo war and the United States war on terrorism in Afghanistan and Iraq, triggered the Chinese realisation of the need to tame the imperialism of the United States in the military arena (Edelman, 2010). China has been developing and procuring a military arsenal with a reach beyond its immediate region. Being a great power, China has expanded it defense spending to include security in the oceans, space and cyberspace with the potential to check the United States "command of the commons" (Edelman, 2010). China has collaborated with Russia to challenge the United States presence in Central Asia and has denied Washington access to establish a military base in China (Skak, 2011).

Thanks to the 2008 financial crisis, China has emerged as an economic super power as it has become more prominent in the international economic order. Following the crisis, G-20 emerged to replace the G-8 as the main economic forum for the major economies. In 2010, the voting rights of China were increased by the World Bank, an action which catapulted China as the third 
largest voter in the Bretton Woods institution. The crisis has also given the Chinese Renminbi international status as China began to work towards the regionalisation of Renminbi. Thus, China signed a currency swap treaty with Singapore, South Korea, Malaysia, Hong Kong, Indonesia and other non Asian nations of Argentina, Belarus and Iceland (Xinbo, 2010, pp. 160161). Also China's cash diplomacy has enabled it to spread its tentacles to European nations such as Greece, Portugal and Spain (Serfaty, 2011). China has become more vocal in international organisations. It plays a prominent role in the activities of Association of Southeast Asian Nations (ASEAN) and is a player in the ASEAN Regional Forum (ARF) and ASEAN+3 talks. It is a major actor in the six party talks on North Korea's nuclear arsenal and has had remarkable contribution towards the United Nations peacekeeping operations (Chen \& Feffer, 2009).

However, China's weaknesses abound. While China is undoubtedly the second largest economy in the world, its GDP per capita is appalling. It is still regarded as a developing country and its rise causes fear in its region. Serfaty gave an apt description of the shortcomings of China's economy. He asserted:

As an aggregate, China is an economic superpower - it is the second largest economy in the world by GDP, having passed Japan in the summer 2010 (and projected to surpass the United States by 2030 or earlier). But if measured in terms of per capita income, China ranked 133rd out of 229 countries in 2008. While the average standard of living in Shanghai approximates Portugal, one of the poorest EU15 countries, in rural provinces it is near Rwanda. Predictably, even under conditions of sustained economic growth, China faces difficult societal disruptions along demographic (young-poor), regional (urban-rural), professional (white collar-labor), and gender lines, in addition to political issues of ideology and governance. (2011, p. 10)

Table 5.2 that follows reveals the GDP per capita of the ten largest economies in the globe.

Table 5.2: Gross Domestic Product per capita (US \$)

\begin{tabular}{|l|l|l|}
\hline Country & $\mathbf{2 0 1 1}$ & $\mathbf{2 0 1 2}$ \\
\hline Brazil & 12575.9794 & 11339.5211 \\
\hline China & 5447.34142 & 6091.01435 \\
\hline France & 42521.8129 & 39771.8428 \\
\hline Germany & 44314.9662 & 41862.7105 \\
\hline India & 1533.66131 & 1489.22901 \\
\hline Italy & 36147.6461 & 33071.8393 \\
\hline Japan & 46134.5682 & 46720.3567 \\
\hline Russia & 13284.0326 & 14037.0154 \\
\hline UK & 39503.3146 & 39093.4728 \\
\hline USA & 49853.6823 & 51748.5615 \\
\hline
\end{tabular}

Source: World Bank 2013 
The table clearly shows that the BRICs Asian tigers significantly lag behind the other great powers in terms of GDP per capita. At \$1533.66131 and \$1489.22901 in 2011 and 2012 respectively, India is clearly the country with the least per capita income. India is closely followed by China on the table which accounted for \$5447.34142 in 2011 and 6091.01435 in 2012.

The rise of China has been accompanied by rising fear in countries such as Vietnam, Australia, Venezuela, Nigeria, Sudan and several Asian nations where it seeks resources. There have also been mixed feelings of fear and acceptance in strategic states where China seeks to have geopolitical advantage, such as Brazil and South Africa (Serfaty, 2011). Other Chinese challenges include high income disparity, an insatiable appetite for foreign energy, high levels of corruption and environmental degradation. However, in a simple sense, China is the most obvious candidate to challenge the US as the hegemon of the global political economy. But for all its fast and continuing economic growth, it is affected by a host of problems generated by its particular experience of late industrialisation and single-party politics. These include: a core imbalance in its economy between investment and consumption, considerable ongoing financial instability, deep social inequalities and tensions, and the confusion about intentions, inevitably generated by its opaque and increasingly corrupt state structure. And this without mentioning the big, looming issue of being pressured to move at some point in a democratic direction. The reality is that for all the talk a while ago of an emerging 'Beijing Consensus', China has yet to produce a style of capitalism that is globally attractive. ${ }^{48}$

\subsubsection{China's soft power currencies}

For China, the sources of soft power are much more limited, and might include its development model and Confucian culture. However, whether a specific aspect of soft power is attractive to a specific foreign country very much depends on the particular conditions of that country. As such, what is seen as a soft power of China by one country might be seen differently by another country. ${ }^{49}$

\footnotetext{
${ }^{48}$ An interview with Nigerian scholar 1

${ }^{49}$ An interview with Chinese scholar 1
} 
In recent decades, the Chinese culture has been a source of burgeoning international interest. Accordingly, the Chinese government has been making tremendous efforts to spread the Chinese culture in Asia and at the globe at large. To this end, the government has sponsored Chinese cultural festivals in countries such as the United States and France (Gill \& Huang, 2006). The Chinese Hànyǔ Shuǐpíng Kăoshì (HSK) - an equivalent of teaching of English as a foreign language (TOEFL) - has drawn candidates across the world (Gills \& Huang, 2006). This implies that that there has been a dramatic increase in the number of foreign students showing an interest in studying in China. Huang \& Ding (2006) have observed that within ten years, the number of foreign students in China tripled and majority of the students are from Asian countries, most especially South Korea and Japan. While it can be argued that the rising Chinese economy is a major source of attraction to the foreign students, the Chinese culture is also important as illustrated by the vast number of students that are enrolling in disciplines embedded in Chinese culture such as Chinese language, arts, history, philosophy and traditional Chinese medicine (Huang \& Ding, 2006). In other words, China appears to be a cultural hub for the East Asian and South East Asian countries which is evident in certain elements of Chinese culture shared by these other Asian countries (Huang \& Ding, 2006).

Confucianism is the basis of traditional Chinese culture and has remarkable influence in Asia. While the Confucian values had been relegated to the background in the past, , the ascendance of China has been accompanied by the rise once again of Confucian values in East Asian countries. It is interesting to note that some of the core values of Confucianism, such as the notion of the primacy of the group rather than individual, are antithetical to the western values. Other Confucius values include promotion of harmony and order, diligence, prudence; the preeminence of the family in social structure formation and the significance of virtues and ethics (Cho \& Jeong, 2008). The Chinese government has been making tremendous progress in infusing the Confucius values into Chinese ideology and foreign policy. The Chinese Confucian democracy seeks to establish a harmonious society, people oriented policies and a socialist view of rewards and punishments (Cho \& Jeong, 2008). In the realm of foreign policy, China adopted principles such as peaceful co-existence with its neighbours, ensuring prosperity and safety in its immediate region and the promotion of a harmonious world from Confucianism. 
The Chinese set a target to establish 100 Confucius institutes around the world. By 2007, China had already surpassed the target by successfully founding 210 Confucius Institutes in 64 countries and regions (Wang, 2008). The primary responsibilities of the institutes were to exhibit Chinese culture in their host countries. The institutes also strived to portray a positive image of China to other countries (Huang \& Ding, 2006).

As Nye (2004a) rightly pointed out, when a state is able to draw foreign students across the globe, the students imbibe the culture of such a state and when they return to their home countries, they may become sympathetic to the cause of that state. Against this backdrop, writing in 2006, Gill \& Huang observed that the Chinese official statistics showed that around 30 former foreign students in China were ministers in their countries, over 10 were ambassadors to China and over 120 were senior staff at universities in their countries (Gill \& Haung, 2006, p. 19). In an attempt to promote the Chinese culture abroad, the Chinese government has been more than willing to promote cultural exchanges with other countries and this action has yielded tremendous benefits evident in the huge volumes of foreign tourists visiting China. According to Huang and Ding (2006), the number of tourists in China (with the exemption of the Chinese tourists from Hong Kong, Taiwan and Macau) have multiplied from 0.23 million to 20.26 million between 1978 and 2005 (Huang \& Ding, 2006, p. 27).

China's domestic values and policies are also an important source of its soft power. The economic reforms that began in the late 1970s that led to the adoption of economic liberalism and the resultant impressive economic growth and performance over the last four decades, has significantly boosted the image of China around the world and its model is considered as worthy of emulation. Contrary to Washington Consensus, the Beijing Consensus does not believe in “one size fits all” policies for all countries' economic problems. The solutions proffered for each country must reflect the peculiarities of that country (Huang \& Ding, 2006).

'The Beijing Consensus' (BJC) is a concept / theory, first discussed by Joshua Cooper Ramo (2004: The Beijing Consensus, The Foreign Policy Centre, London) and further developed by Halper (2010: The Beijing Consensus: How China's Authoritarian Model Will Dominate the Twenty-first Century, Basic Books) which draws together the different aspects of Chinese soft power, delineates the powerful links between economic and soft power, and explains China's muscle. Ramo (2004, pp.1112) explains the three central theorem's of the BJC: a) the key to development is 'bleeding-edge innovation' to 'create change that moves faster than the problems change creates'; b) fundamental need to shift development's focus to individuals, their 'quality-of-life' with sustainability and equality 
as priorities; c) a security doctrine which stresses self-determination, through the use of leverage and asymmetry. ${ }^{50}$

According to Ramo (2004), the Beijing Consensus encompasses three attributes for a developing country in the international system. Firstly, the search for innovation and pragmatic reforms to proffer solutions to problems. Secondly, a developmental model that emphasises the quality of life of the people rather than the per capita GDP. Thirdly, a commitment to self determination in its external relations in order to be assertive in the international system and prevent being dictated to by the great powers.

Particularly after the 2008 financial crisis, the Chinese model has gained wider currency in scholarly writings and public analysts' debates. In the words of Robert Kaplan, "China shows you can have economic freedom without political freedom, where we used to think they were indivisible" (quoted in Gill \& Huang, 2006, p. 21). The Washington consensus with its emphasis on democracy and market fundamentalism has caused a global economic crisis. Whereas the Beijing consensus is, at the political level, authoritarian it has also promoted economic growth. People get rich in the midst of corruption and the country is stable. This has given China the image of wealth across the globe. The authoritarian state of China is doing well while the socalled democratic states of the US and Europe in decline. ${ }^{51}$ In other words, China has been able to find a blend of authoritarian political system with some elements of economic liberalism and this has worked well for the Asian great power. China's "soft power" is mostly based on its recent economic successes, and it will be interesting to see if this translates into broader international influence or a desire by others to emulate the "Chinese model." 52 The success of this model has appealed to a number of countries. Therefore, Russia ${ }^{53}$ has given priority to how it can improve its economy rather than democracy. The other CIS countries such as Uzbekistan, Turkmenistan and Kazakhstan have also embraced the Chinese economic model. Within Asia, the Indian Prime Minister, Manmohan Singh, remarked that India should emulate Chinese model towards economic growth and global trade (Gill \& Huang, 2006). In Latin America, the former Brazilian President, Luis Inacio Lula da Silva, was reported to have sent investigatory teams to

\footnotetext{
${ }^{50}$ An interview with a Nigerian scholar 1

${ }^{51}$ An interview with Chinese scholar 2

52 An interview with American scholar 1

${ }^{53}$ While it can be argued that Russia has not always shown much commitment to democracy, perhaps, the success of the Chinese model might further reinforce Russia's attitudes towards democracy.
} 
study the Chinese economic model. In Africa, authoritarian regimes may embrace the model and the influence of China in African countries as illustrated by the success of the China-African summit of 2006 attended by 48 African countries (Wang, 2008). In the Middle East, the conservative leaders in Iran have been influenced by the Chinese model (Gill \& Huang, 2006).

China has successfully combined a market economy with an authoritarian state which is evidenced in its remarkable economic performance. This has generated interest across the world. As one observer indicated, "from Vietnam to Syria, from Burma to Venezuela, and all across Africa, leaders of developing countries are admiring and emulating what might be called the China Model" (Zhao, 2010, p. 419). Following the United States foreign policy failure and economic setback and the attendant recent criticism of the Western liberal ideas, the Chinese model appears to be an alternative to many developing countries striving for economic development. Contrary to the West that demands compliance to certain principles such as democracy, transparency, good governance, rule of law and respect for human rights from other states before cordial relations, China's relation with other states is largely determined by economic and strategic interests (Zhao, 2010). Thus, countries that have been sanctioned and isolated by the West for non-compliance with those principles, find a friend in China that is prepared to have a relationship without meddling in their domestic affairs. Accordingly, countries like Iran and Zimbabwe enjoy close ties with China. These are countries to which the Western world has applied sanctions due to their domestic politics. The unconditional economic aid and assistance China offers the developing countries, most especially in Africa and Asia, has further enhanced the image of China among these countries (Zhao, 2010).

China's foreign policy is undoubtedly another instrument of its soft power. In the post-Mao period, China "has adopted a less confrontational, more sophisticated, more confident and, at times, more constructive approach toward regional and global affairs" (Gill \& Huang, 2006, p. 21). This posture is geared towards a stable international system which enables China to concentrate on its domestic issues and economy. Thus, according to official statements, China desires to promote international norms such as peaceful settlement of disputes and combating of global threats like terrorism and disarmament and arms control. Rather than be confrontational towards the other great powers, most especially the United States, China maintains a constructive relationship with them (Huang \& Ding, 2006). 
In order to counteract the negative perception of China, especially perceived threat that accompanies the rise of China, the Chinese government has promoted the strategies of peaceful rise and peaceful development in the global arena. According to Cho \& Jeong (2008), Chinese scholars agree that the concept of peaceful rise has transformed the Chinese foreign policy objectives in three significant directions. Firstly, China's neighbours are now the cornerstone of its foreign policy rather than the United States. Secondly, there has been a shift of foreign policy from striving for acceptance in the international community to playing a global role as a player with magnitude. Thirdly, a shift in policy targeted towards economic development to harnessing resources to boost all the major elements of power of a state. Thus, the peaceful rise strategy connotes the policies implemented by China towards becoming a true global player, particularly through harnessing its national power to achieve this end. Perhaps it was in the realisation of the ascendance of China as a true great power with influence beyond its immediate region that the Chinese policy makers substituted the peaceful rise slogan with peaceful development. Cho \& Jeong (2008) argued that it is a mere change of term as there appears to be little other real difference. Perhaps the change reflects the conviction in some quarters that China has already risen and can now develop with other great powers.

China has also realised the importance of multilateral institutions in the pursuit of its foreign policy. China has made a u-turn in order to effectively engage international organisations. The China-ASEAN free trade area has given China an opportunity to establish closer ties with the East Asian countries and it seeks to tilt the balance of power politics that exist between China and the United States in this region in its favour. In 2003, China became a member of the Southeast Asia Treaty of Amity and Cooperation and has also been actively involved in regional security talks like the ASEAN Regional Forum (ARF). Its activities in the UN peacekeeping missions also cannot be overemphasised. By 2005, China had mobilised 4,000 soldiers and police towards $14 \mathrm{UN}$ peacekeeping missions and in the last few years, China's military deployment under the umbrella of the United Nations has been more than any of the permanent members of the Security Council and NATO members (Gill \& Huang, 2006, p. 22). China was also the prominent player in the establishment of Shanghai Cooperation Organisation (SCO) with the aim of gaining common ground in political, economic and security concerns that cut across the states of China, Russia, Kazakhstan, Kyrgyzstan, Tajikistan and Uzbekistan. 
However, the ability of China to wield its soft power is constrained by a number of factors. The Beijing consensus places much emphasis on pragmatism rather than on moral appeal which may significantly win the minds and hearts of other states (Zhao, 2010). The Chinese model is also characterised by income inequality, massive environmental pollution and high levels of corruption (Xinbo, 2010). The projection of a state's soft power is largely in the realm of the society. Owing to the strong state and weak society in China, the Asian power has been unable to harness adequately the resources of non-governmental organisations and multinational corporations to promote the Chinese brand around the world (Wang, 2008). Table 3 below shows China's favourability across the globe.

Table 5.3: China's favourability

\begin{tabular}{|l|l|l|}
\hline Country & Favourable (\%) & Unfavourable (\%) \\
\hline Canada & 43 & 45 \\
\hline US & 37 & 52 \\
\hline Africa & 72 & 15 \\
\hline Latin America & 58 & 22 \\
\hline Asia & 58 & 35 \\
\hline Middle East & 45 & 52 \\
\hline Europe & 43 & 47 \\
\hline
\end{tabular}

Source: Pew Research Centre 2013

Table 5.3 shows that China's favourability rating is not impressive in the North American countries and is relatively poor in the Middle East. Its image is above average in Asian and Latin America. One region that China enjoys a remarkable rating is in Africa. To this end, the next section explores China's soft power currencies in Africa. Similarly Table 4 shows the position of China in the ranking of the global soft power states.

Table 5.4 reveals that China is ranked eighth among the 14 countries. It also shows that the United States is in a class of its own in terms of its soft power resources. 
Table 5.4: The top soft powers

\begin{tabular}{|l|l|l|l|l|l|l|l|}
\hline Rank & Country & $\mathbf{2 0 0 5}$ & $\mathbf{2 0 0 6}$ & $\mathbf{2 0 0 7}$ & $\mathbf{2 0 0 8}$ & $\mathbf{2 0 0 9}$ & $\mathbf{2 0 1 0}$ \\
\hline 1 & US & 84.0 & 85.5 & 86.3 & 88.1 & 87.0 & 87.0 \\
\hline 2 & France & 49.7 & 48.4 & 50.3 & 49.6 & 49.6 & 49.5 \\
\hline 2 & Germany & 44.0 & 46.6 & 46.6 & 45.8 & 44.0 & 43.2 \\
\hline 4 & UK & 46.0 & 45.9 & 46.3 & 46.0 & 46.7 & 43.0 \\
\hline 5 & Canada & 36.0 & 39.4 & 38.6 & 36.8 & 35.3 & 39.0 \\
\hline 6 & Italy & 33.0 & 34.6 & 33.9 & 34.6 & 34.2 & 32.0 \\
\hline 7 & Japan & 36.9 & 36.5 & 35.5 & 34.7 & 32.5 & 31.8 \\
\hline 8 & China & 31.1 & 32.2 & 32.2 & 32.2 & 33.7 & 30.7 \\
\hline 9 & India & 22.6 & 21.5 & 21.9 & 26.7 & 22.6 & 20.4 \\
\hline 10 & Russia & 22.9 & 18.4 & 22.9 & 21.0 & 23.5 & 18.0 \\
\hline 11 & Brazil & 5.9 & 6.0 & 9.3 & 12.7 & 9.7 & 13.8 \\
\hline 12 & Turkey & 10.3 & 12.5 & 11.4 & 14.4 & 10.3 & 12.9 \\
\hline 13 & Mexico & 10.0 & 11.8 & 11.8 & 17.1 & 19.3 & 11.5 \\
\hline 14 & South & 13.0 & 10.0 & 8.5 & 12.6 & 11.8 & 10.3 \\
& Africa & & & & & & \\
\hline
\end{tabular}

Source: RGM Soft Power Index (2012)

\subsubsection{China's soft power in Africa}

China's renewed interest in Africa in the $21^{\text {st }}$ century has generated considerable reaction, most especially among African and Western countries' analysts and observers. In Africa, China's recent incursion into the continent has been interpreted in two distinctive ways. Firstly, the Asian power provides opportunities to African countries in the form of trade, investment and an alternative developmental model. Second, the imperial tendencies of China seek to exploit the huge natural resources of Africa. In the West, the concern is the possibility of a declining Western influence in Africa with the growing importance of China in Africa (Cooke, 2009). China's growing influence is inevitably causing some discomfort in Africa itself, with Lamido Sanusi, the governor of the Central Bank of Nigeria, recently arguing that China's "win-win" approach now involves too much "win" for the Chinese, and too much "loss" for the Africans. However, even Sanusi's critique acknowledged China's enduring soft power. "A romantic view of China is quite common among African imaginations," he observed, adding that "this African love of China is founded on a vision of the country as a saviour, a partner, a model." Sanusi's message was that Chinese soft power in Africa will evaporate if China pursues a hard-power 
path in which it simply buys influence and resources without benefitting the Africans themselves. ${ }^{54}$

Perhaps the realisation of the negative perception of some African countries of China, it has shifted attention into projecting itself in Africa through its soft power currencies. According to Kim (2013, p. 9) “There are several ways that China's soft power has been spread such as writing off debt from African countries; training more Africans in Chinese universities; sending more doctors to work across Africa; and facilitating major investments in infrastructure, agriculture, and energy".

China seems to have assumed the role of the champion of African and developing countries and has treated African countries with respect with its policy of non-interference in their domestic affairs. China's principles on sovereignty and non-interference in the internal affairs of states are appealing to African elites, most especially African states with authoritarian regimes. Thus, unlike the Western countries which have imposed sanctions on the Zimbabwean and Sudanese regimes, China relates to these countries with open hands. It is worth noting that China is not alone in its stance on these countries. For instance the Southern African Development Community (SADC) does not see the need for the sanctions to be imposed on Zimbabwe. Accordingly, China enjoys the support of some African states and citizens on this issue.

According to Cooke (2009), the Chinese win-win trade policy in Africa has been received with approval in Africa because of the following three reasons. Firstly, rather than prescribing values to African countries, China sees itself as a business partner. Secondly, primacy is given to economic diplomacy rather than humanitarian diplomacy. Thirdly, leeway is given to Africa to determine the terms of the engagement. China's relation with the oil producing states of Nigeria, Angola and Sudan is worth considering. Western hostile relations with Sudan have provided an opportunity for China to wield maximum influence in this country. China has been wanting to become more influential in Nigeria and Angola to counteract the dominance of the Western oil companies in these countries. Thus, China has used diplomatic, security and economic engagements to enhance its advantage in these countries in comparison to the United States. China's \$2 billion loan to Angola in 2004 and another \$2 billion loan in 2007 for the

\footnotetext{
${ }^{54}$ An interview with Nigerian scholar 1
} 
reconstruction of the infrastructure that had been destroyed by the civil war was greatly appreciated by the Angolan government. The loan appeared to be exactly what Angola needed in the period when the West used liberal reforms as conditions for financial assistance. This prompted Angola's deputy prime minister, Aguinaldo Jaime, to assert that "China came to Angola with critical assistance at a time when the international community refused, insisting on excessive and unreasonable conditions to more robust assistance" (Cooke, 2009, p. 30). However, the construction work was done by Chinese companies, with Chinese workers and materials, despite the high levels of unemployment in Angola. The Angolan government appeared unconcerned with Chinese actions because of its dire need for help (Cooke, 2009).

China's diplomatic presence and shuttles in Africa are clearly evident. Beijing has established diplomatic relations and maintains embassies in all African countries except Somalia. It has embassies, offices of commercial counsellors and Consulate Generals in 48, 40 and 5 of those countries respectively (CRS, 2008, p. 110). In terms of diplomatic shuttles, the former President, Hu Jintao, visited 14 countries in three African tours. Similarly the Premier,Wen Jiabao, has visited eight African countries. What is worth noting is that the visits were not limited to the strategic countries in Africa. Countries such as the Central Africa Republic, Madagascar and Seychelles, of little or minimal strategic importance to China's interests, were also visited. These visits are likely to boost the image of China, most especially in the small countries in Africa that are given little recognition in the international arena (Cooke, 2009). Some of the primary objectives of China's engagement in Africa are to be able to garner the support of African countries in the pursuit of its interests in the United Nations and other multilateral arrangements; and to guarantee future economic ties with African countries (CRS, 2008). Thus, African countries have been vocal in the United Nations Commission on Human Rights to thwart the Western attempts to invoke a formal condemnation of China's human rights record (Tull, 2006). China regards itself as the champion of African and developing countries in general and provides its developmental model as an alternative to the Western economic model in Africa (CRS, 2008). Unlike the Western countries, China offers total package deals to Africa. In other words, China integrates business, political, aid and military deals in its relations with African countries. This contradicts the Western countries' dealings with African states because the West usually separates their military, aid and diplomatic programmes in Africa. Therefore, African countries might find China's engagement more appealing than their relations with the West (CRS, 2008). 
Among others, China's engagement in Africa has the tendency to yield the following benefits to African countries. Firstly, a burgeoning of China's investment in Africa, most especially in infrastructure. Secondly, increasing Africa's exports to China provides Africa with increasing wealth. Thirdly, it reduces the African dependence on Western aid and conditionalities. Fourthly, China serves as an alternative great power ally of African states (CRS, 2008).

In 2000, China and the African countries established the Forum on China-Africa Cooperation (FOCAC) with the primary objective "to build mutually beneficial economic development, trade cooperation and political relations with Africa" (CRS, 2008, p. 108). Since then, FOCAC has been holding summits triennially alternating between China and African countries. This forum has provided a platform by which China outlines its policies and makes its pledges to Africa. The construction of the African Union headquarters in Ethiopia was financed by China. The building was estimated to have cost between $\$ 100$ million to $\$ 150$ million (CRS, 2008). China also contributes to the AfDB and finances some AU and United Nations peacekeeping missions. FOCAC serves as a platform for African leaders to visit China and it has emerged as the second largest gathering of African Heads of States. The African attendance in FOCAC is only surpassed by the United Nations African presence (Bodomo, 2009). China also engages Africa through other multilateral arrangements such as African Development Bank (AfDB) and the African Union. China attended some important AU summits between 2006 and 2007 and it has an observer status in many sub-regional multilateral institutions in Africa (CRS, 2008). In 2007, the construction of the African Union headquarters in Ethiopia was financed by China. The building was estimated to have cost between $\$ 100$ million to $\$ 150$ million (CRS, 2008). China also contributes to the AfDB and finances some AU and United Nations peace keeping missions such as in Somalia and Sudan (CRS, 2008). In 2004 alone, 1,400 Chinese forces were involved in nine United Nations missions in Africa (Tull, 2006).

China has sought to promote its culture in Africa through the Confucius Institutes it has established in African countries. The first of these institutes was established in 2005 in Kenya and the Asian powerhouse has established more than 20 Confucius Institutes since then. The Institutes' primary objective is to promote the Chinese culture and language in their host countries. Accordingly, in 2008, China pledged 20 million renminbi to South Africa on education project that would involve the teaching of Mandarin in 50 high schools (Cooke, 2009). 
There has also been an increasing wave of migration between China and Africa. This is particularly evident in the movement of entrepreneurs from China to Africa and vice versa (Cooke, 2009).

China's model of economic growth and strong government is admired by authoritarian regimes and even some democratic regimes in Africa (Horta, 2009). Thus, China enjoys cordial relationship with President Robert Mugabe in Zimbabwe, President Ali Bongo in Gabon and president Paul Biya in Cameroon (Fijalkowski, 2011).The replication of this model also provides Africa with an avenue to market their resources to China (Fijalkowski, 2011). "In 2001, the value of its imports from Africa was roughly $2.3 \%$ more than those of its exports. By 2004, this proportion had risen to $46.5 \%$..." (CRS, 2008, p. 119). Even though China encourages African investment in China, in reality the African countries' investment in the Asian powerhouse is tiny. In 2004 and 2005, Mauritius and South Africa garnered 82\% and 12\% of African investment in China in that order (CRS, 2008, p. 119). China also gives loans with no conditionality to African states for the construction of infrastructure, investment in agriculture and enhancement of security (Wenping, 2010). It is also in China's policy to finance symbolic buildings like a seat of power, headquarters and football stadiums in Africa which are greatly appreciated by African leaders because such buildings tend to help African leaders score political points (Tull, 2006).

In his study on China's soft power in Africa, Horta (2009) argued that the African elites are fond of blaming Western liberalism for their economic challenges and they have found an alternative in the Chinese model. In Horta's interviews with 67 African political office holders, he found that 63 officials held positive views about China. This is contrary to his interviews of 98 African citizens in which 73 had a negative perception of China. The positive image China has among the African political elites may be attributed to China's notion of sovereignty and noninterference in internal affairs of African states coupled with the no-strings attached loans. In the words of a spokesman of the Kenyan government: 'You never hear the Chinese saying that they will not finish a project because the government has not done enough to tackle corruption. If they are going to build a road, then it will be built' (Tull, 2006, pp. 466-467).

China is expanding and reaching out to the rest of the world not only to extract resources but also to look for markets in order to be able to sell its surplus produce. This explains China's presence 
in Africa where there are resources, as in Nigeria. They are able to make inroads into Africa because, unlike the Western world, the Chinese do not "moralise". They are not engaged in moral preachings about democracy, human rights and they are not imposing their culture and ways of life on anybody. They request friendly and economic relations. In exchange for taking resources, they offer assistance in building infrastructure. According to a Nigerian scholar, across the African continent today, most of the major construction is being done by the Chinese on soft loans. The loans and grants from the Chinese seem to be easier to access for Africa and other third world countries than Western aid that comes with many political conditionalities and considerable debilitating legal and social obstacles which make them very difficult to access. For example, the Nigerian National Assembly has legislated against gay marriage and the British government has openly said that it would consider cutting aid to Nigeria because this is in violation of human rights. Wouldn't a country that believes it is sovereign in terms of its domestic policies consider it offensive to be dictated to because of aid, especially when there is another power prepared to give aid without moralising. For this reason the Chinese influence is growing gradually and if care is not exercised, it will challenge and may overtake Western nations on a continent which used to be their primary area of influence. "In terms of winning hearts and minds of third world people to itself, I think the Chinese are making a hefty progress" ${ }^{55}$ The combination of China's cancellation of some African countries debts, provision of soft loans, burgeoning imports from Africa undercut the Western aid and their conditionalities which have not been effective illustrated by the Western aid to the tune of billions of dollars which has not successfully constructed a railway network in Nigeria or power grids in the Horn of Africa (Khanna, 2009).

On the other hand, the African citizens' negative perception perhaps reflects the influx of the Chinese citizens in Africa countries who are employed in the Chinese construction companies at the expense of the huge number of unemployed African people and also the Chinese entrepreneurs who set up businesses in Africa with which African entrepreneurs struggle to compete. In the words of a Mozambican high school teacher: "They say China is a great power just like America. But what kind of great power sends thousands of people to a poor country like ours to sell cakes on the street and take the jobs of our own street sellers who are already so

\footnotetext{
${ }^{55}$ An interview with Nigerian scholar 2
} 
poor" (Horta, 2009, p. 2). According to a South African scholar, Chinese soft power is considered foreign in Africa. We rarely see African people eating with chopsticks or eating a bowl of Chinese food. There are very few Chinese restaurants in South Africa and very few black people patronise them. They are patronised largely by white South Africans. Chinese music is not popular in Africa. ${ }^{56}$ Moreover, the political values of democracy and human rights are very popular in Africa and Africans citizens are not willing to let go of these values. African academics feel that China does not take these values seriously (Wenping, 2010). A Nigerian scholar opined that one has to bear in mind that the Chinese are coming from a background of totalitarianism. They are now being forced by the global circumstances to liberalise the economy but they retain totalitarian policies. Africa does not have that kind of totalitarian background. Instead, in Africa there is a dictatorial background, military rule, autocracy, and sit-tight governments. It is not feasible that Africa can replicate the Chinese model no matter how much they want to admire it. ${ }^{57}$

In general, China has the tendency to win over African states because it does not impose tariff on the exports from the 25 poorest countries in Africa (Fijalkowski, 2011, p. 230). If you want to see China in an attractive light, Africa surely provides the best vantage point. In fact, Chinese involvement in Africa has mainly taken the form of co-operative development, rather than aid. Africans are generally receptive to China's developmental approach: they observe with approval one developing country helping another, "the poor helping the poor"; they value the longstanding connections built over decades with their Chinese partners. In Africa, China's image has been thriving, principally because of its contribution to economic development, mainly through the building of infrastructure projects and advancing the technological capabilities of many developing nations. "This advantageous image, of the benevolent actor who delivers results, combined with the 'spirit' and values enshrined in the Beijing Consensus BJC explains why now most of Africa looks to China rather than the US for a reliable partner". ${ }^{8}$ There is very little doubt that China presently wields huge soft power Africa. And Chinese influence, which could be said to be comparatively positive in Africa, began as far back as the construction of the Tanzanian Railways in East Africa. More recently, we see the immense infrastructural projects

\footnotetext{
${ }^{56}$ An interview with South African scholar 2

${ }^{57}$ An interview with Nigerian scholar 2

58 An interview with Nigerian scholar 1
} 
China had undertaken or is involved with in different parts of the continent. ${ }^{59}$ Table 5 below depicts China's favorability in selected African states.

Table 5.5: China's favourability in Africa

\begin{tabular}{|l|l|}
\hline Country & Favourable (\%) \\
\hline Kenya & 78 \\
\hline Ghana & 67 \\
\hline Senegal & 77 \\
\hline Nigeria & 76 \\
\hline South Africa & 48 \\
\hline
\end{tabular}

Source: Pew Research Centre 2013

Table 5.5 shows that China is generally perceived in positive light in Africa. However, as soft power is about relations and is based on an assumption that an ability to attract others changes their preferences in a way that they act in the interests of the country projecting attractiveness, it is difficult to argue that China projects soft power in Africa (Fijalkowski, 2011, p. 231). "I do not believe either China or the United States wield great "soft power" in Africa, although the United States is probably a bit more influential than China is." ${ }^{\circ 0}$ In Africa, there is the Chinese economy is attractive. China has a very strong private sector. "However, African states are enthusiastic about not replicating the Chinese authoritarian, communist party system. There is no open contest to elect the president of China. China has very few African students' presence in their universities."61 "I do not think the Chinese already has the cultural and technological wherewithal to get to the people not just the government like the Americans. It will take time for the China's information system to be so pervasive to be telling us their own side of the story. They have but it is not as influential as the BBC and CNN. People are still skeptical about the Chinese products. When you mention anything that is substandard, you hear it is made in China. China will have to overcome that adversity among other things." 62

\footnotetext{
${ }^{59}$ An interview with Nigerian bureaucrat

${ }^{60}$ An interview with American scholar 1

${ }^{61}$ An interview with South African scholar 1

${ }^{62}$ An interview with Nigerian Scholar 2
} 


\subsubsection{China's soft power in the Middle East}

The necessity to sustain Chinese growth which had been impressive in decades prompted the Chinese "going out" policy in 2001 in order to secure overseas sources of energy and investment. Accordingly, there was growing Chinese interest in the Middle Eastern oil (Chen, 2011). There has been a flood of Chinese politicians, entrepreneurs and ordinary citizens in the Middle East. While China was once self-sufficient in its production of oil for local consumption till the early 1990s, it has now emerged as a large importer of oil and with the Middle East accounting for more than half of China's annual importation of oil (Alterman, 2009). As China continues to grow, so also will its appetite for oil. According to the International Energy Agency, China will start to import 75 percent of its energy by 2030 (Alterman, 2009). The volume of trade between China and the Middle East has skyrocketed in the last decade. For instance, between 2005 and 2009, the volume of trade between China and the Middle East increased to 87 percent. China's imports from the Middle East alone increased by 25 percent and it has outwitted the United States as the largest trading partner of the Middle Eastern countries (Chen, 2011). This is in contrast with the trend of trade between the Middle Eastern countries and the United States which decreased by 45 percent in those years (Chen, 2011, p. 2). The relatively cheap Chinese products available in the Middle East have significantly impacted on the purchasing power of the Middle Eastern people.

The oil producing Middle Eastern countries consume Chinese goods such as manufactured goods, equipment, foodstuff, vehicles and services like engineering and labour services (Abisellan, 2012). A burgeoning number of Egyptians can afford to buy a car due to the abundance of relatively cheap Chinese cars in the region and similarly the Gaza people have relied heavily on the cheap Chinese products to counteract the Israeli blockade (Chen, 2011). The Chinese are coming in with cheap products which are not necessarily substandard.

\footnotetext{
For the emerging middle class in the third world, it costs much less to buy a big Chinese car that gives the appearance of a big man rather than buy the much more expensive American or Japanese cars of the same class. They are also coming in with their personnel, building roads, structures, bridges, high ways etc. We are seeing more of their presence and there are China towns in a number of countries. What they sell are Chinese and the sellers are Chinese. ${ }^{63}$
}

In highlighting the extent of China's investment in the Middle East, Chen's observation is worthy of extensive quotation:

\footnotetext{
${ }^{63}$ An interview with Nigerian scholar 2
} 
Investment flows from China have grown tenfold, from $\$ 1$ billion in 2005 to $\$ 11$ billion in 2009; China is the largest foreign investor in both Iraq and Iran. Middle Eastern governments have also reached out by bringing Chinese contractors in to work on major infrastructure project investments. Saudi Arabia hired the state-owned China Railway Construction Corporation to work on the Mecca monorail project, which went into operation in November 2010, just in time to accommodate the 2.8 million people who arrived for Hajj. Egypt has also partnered with China to develop its Suez special economic zone, and the Iraqi government awarded five separate contracts to Chinese oil companies to develop its long-neglected oil fields. In addition, China signed an agreement with the Iranian government to build a railway line from Tehran to the Iraqi border as part of an overall plan to link the Middle East to Central Asia and China through rail. Chinese influence is also evident in Northern Africa, where the Algerian government hired Chinese construction firms for several major projects including an airport, a mall, 60,000 homes, and a 745-mile east-west highway, the longest on the continent. (Chen, 2011, p.2)

Similarly, the United Arab Emirates has become a significant trading partner of China. Over 1,000 Chinese firms are operating in the UAE and Dubai is the host city of the Dragon Mart, a 150,000 square metre mall selling a variety of Chinese goods (Alterman, 2009). China is a major supplier of Iran's arms and ammunitions. Between 1998 and 2004, Iran purchased anti-ship missiles and air surveillance radars from China. Iran also purchased Chinese weapons parts which Iran assembled locally. There is also growing suspicion regarding China's assistance towards the Iranian nuclear programme (Alterman, 2009).

China's policy of non-interference in the internal affairs of other states has benefited the Asian powerhouse in its relations with the Middle Eastern countries. Unlike the other great powers which have a relatively small influence in the oil-rich region, China appears to be the only state that has cordial relations with all four of the major ethnic groups in the region - Arabs, Persians, Turks, and Jews. Regimes that have strained relationship with the West over their human rights records find friendship with China (Chen, 2011). China has also engaged the Middle East through multilateral arrangements like the Organisation of the Islamic Conference (OIC), the Arab League and the Gulf Cooperation Council. This has provided the platform for China to promote trade and investment with member states of these organisations and seldom promotes China's strategic interests (Chen, 2011).

The Middle Eastern governments generally find the Chinese model more appealing than the Western model. The Chinese model is popular among the Iranian conservative leaders and, former President Akbar Hashemi Rafsanjani contested the 2005 presidential election with the promise of institutionalising the Chinese model in Iran (Gill \& Huang, 2006). Various opinion polls have shown that ordinary people in the Middle East view China in a more positive light 
than the United States. Polls like the Arab Youth Survey carried out by a public relations agency in Dubai in 2009, the BBC World Service Opinion Poll in 2010, Pew Global Attitude Project Surveys from 2005, and Brookings Arab Public Opinion Poll in 2010 show that China has a higher level of favourability in the Middle East than the United States (Chen, 2011). A major reason for the negative image of the United States in this region stems from its foreign policy, its war on terrorism in Afghanistan and Iraq and its drone attacks in this region. With the growing influence of China in this region, the dragon has sought to promote its culture and language through the establishment of Confucius Institutes across the region. Confucius Institutes have been established in Lebanon, Israel, Jordan, Egypt, Morocco, Iran and UAE (Chen, 2011).

With the rise of China's influence in this region, there is growing concern in Washington over a region which has been of strategic interest to the United States and in which it has established a somewhat hegemonic posture since the United Kingdom influence in the region plummeted. China has thwarted the United States' attempt to put an end to the regime of President Assad of Syria and it has also frustrated United States' efforts to impose sanctions on Iran. China has emerged as Iran's largest trade partner following the United States sanctions on Iran. China has benefitted enormously from the international sanctions on Iran by extending its bilateral trade with Iran most especially in the energy sector. Iran accounts for a large share of the oil China imports from the Middle East and this explains why China is unwilling to participate in the United States sanctions on Iran. ${ }^{64}$ Within three years the volume of trade between China and Iran grew from $\$ 14.4$ billion to $\$ 21.2$ billion (Abisellan, 2012, p. 6).

Through the projection of its soft power currencies in the Middle East, the Chinese government sought to achieve two major objectives: firstly, to guarantee the supply of energy to its burgeoning economy, and secondly, to weaken the United States influence in the region (Abisellan, 2012). China's economy has witnessed remarkable growth for three decades and a half and there have been predictions by various agencies that the Asian powerhouse will continue in this direction in the foreseeable future. The Middle East, with its large reservoir of oil, is of strategic and economic importance to China to sustain its economic growth. However, the United States is the most important foreign player in this region. Therefore, China seeks to minimise the influence of the United States in order to boost its bargaining power in the Middle East. These

\footnotetext{
${ }^{64}$ An interview with Chinese scholar 2
} 
objectives have the potential to catapult China into the position of a major player in the Middle East. In 2010, China purchased close to 4.8 million barrels of crude oil daily. At more than 2.2 million the Middle East accounted for 47 percent of the China's oil importation that year. Africa's share was 30 percent, the Asia-Pacific recorded 4 percent and the remaining 20 percent came from other countries (Abisellan, 2012, p. 5).

According to Alterman (2009) China has only shown an interest in playing a role in the Middle East along with the United States and does not appear to wish to oust the United States as the dominant power in the region. China's non-military engagement in the region implies that China still relies on the United States military to guarantee the stability of the region for free flow of oil to other parts of the world including China. China's primary aim in its relations with the Middle Eastern countries is to pursue its economic interests. In doing this, it tries to establish diplomatic and cultural links with the countries in the Middle East. The Middle Eastern countries seem to view China as an alternative great power to the United States (Alterman, 2009). Several Middle Eastern countries have had long established relationships with the United States. A century ago the United States was viewed as a messiah that could liberate the countries in this region from European colonialism. However, the view has changed over the years and America is now itself viewed as an imperial power which seeks to impose reform in the Middle Eastern countries. China is seen in more positive light owing to its indifference to the internal politics of the Middle Eastern countries (Abisellan, 2012). China is not concerned about how elections are conducted, the human rights record, the level of transparency, the level of corruption and other good governance indicators in the Middle East. Indeed China has provided a model that does not take the values of human rights, and democracy seriously and seems to follow a pragmatic path to economic development (Abisellan, 2012).

China's aid and assistance have also significantly contributed to the bolstering of China's soft power in the Arab world. For instance, China has offered assistance to Yemen in the health sector. In the last four decades, over 2,000 Chinese medical experts had been sent to Yemen to supplement the shortage of physicians in the Middle Eastern country (Alterman, 2009). China has also used education to win the minds and hearts of the Middle Eastern public. According to Alterman (2009) around 1,500 Egyptian college students study Chinese yearly and about 1,000 Egyptians are enrolled in university study at the Chinese Cultural Centre and the Egypt-China 
Friendship Association. The Chinese influence is having a considerable effect on Egyptian universities. Ain Shams University prides itself on having the largest Chinese department in Africa; hundreds of Chinese students enroll in Al-Azhar; the Cairo University inaugurated Chinese department in 2004, and the Egyptian Chinese University in Cairo is the first of its kind in the Middle East (Alterman, 2009). The Saudi students have opportunities to enrol in Chinese universities with scholarships which are awarded by the Chinese Multinational Corporation in Saudi Arabia. This is supplemented by scholarships awarded by the Chinese government to students and professionals (Alterman, 2009).

Realising the asymmetry in trade between China and the Middle East that is massively skewed in China's favour, one of the ways by which China has striven to manage this imbalance is the promotion of tourism in the region. Accordingly, China and Egypt signed an agreement on tourism in 2001 and by 2005 35,000 Chinese tourists had visited Egypt and it is expected that the numbers of Chinese tourists in Egypt will continue to increase. The Chinese tourists in Dubai grew exponentially between 2004 and 2006 largely due to the launch of direct flights by Emirates Airlines between the two countries (Alterman, 2009). Through its Al-Sinal-Yawn, an Arabic edition of its monthly magazine titled China Today, the Asian power has endeavoured to project its soft power. The regional office of this magazine is situated in Cairo and the content is targeted at the Arab audience (Alterman, 2009). Every issue of the magazine has a section entitled "We are all East". This section seeks to reveal the commonalities between the Arab countries and China with the hope that China will be seen in a positive light if the Arab audience is convinced of such similarities (Alterman, 2009). Table 5 below gives an indication of China's favourability in the Middle East.

Table 5.6: China's favourability in the Middle East in 2013

\begin{tabular}{|l|l|}
\hline Country & Favourable (\%) \\
\hline Lebanon & 56 \\
\hline Turkey & 27 \\
\hline Palestine & 47 \\
\hline Israel & 38 \\
\hline Egypt & 45 \\
\hline
\end{tabular}

Source: Pew Research Centre 2013 
Table 5.6 shows that the perception of China in the Middle East is not very impressive. The implication of this is that China still needs to invest in soft power in this region to enable it to effectively wield influence in a region where it is difficult to apply hard power resources to achieve set goals.

\subsection{Conclusion}

There is no gainsaying the fact that the turn of the $21^{\text {st }}$ century has been characterised by the rise of the emerging powers of Brazil, India and China and the resurgent power of Russia amidst the relative decline of the United States. To this end, the emerging powers have bolstered both their hard power and soft power currencies to influence decisions of regional and sometimes global consequences. They often seek to promote their interests through multilateral institutions like the BRIC, WTO, the G20 and the United Nations. They also use these institutions to distort the global configuration of power (which had hitherto largely favoured the United States) in their favour. However, the differences in the interests of these states possibly outweighs their commonalities and, coupled with their respective domestic problems, sometimes results in BRIC countries following the path of the United States or the West even when such a stance jeopardises BRIC's collective interests. This is illustrated in China's and Russia's unwillingness to support the expansion of the permanent membership of the United Nations Security Council to include India and Brazil, and in India's suspicion of China's intention in the Asian continent. In addition, while India and Brazil are democracies, China and Russia are authoritarian states.

Perhaps the relations among these countries would have been much more cordial if they were all democratic states. Despite these challenges, the BRIC countries have emerged as forces to be reckoned with in the international arena. Their impressive growth rate, their expanding volume of trade across the globe, the renewed interest in investing in military hardware and their realisation of the significance of soft power contribute to their growing influence in the international arena. Among the BRIC countries, China is undoubtedly the most important player and appears to be the only great power with the potential to significantly challenge the United States dominance in the global arena. It is predicted by some that China will overtake the United States as the largest economy in this century and observers have toyed with terms like G2 for the United States and China. Despite the impressive performance of China over the years, the 
Chinese government does not appear to be ready to assume the position of a true global power reflected in their reluctance to impose solutions where these are needed across the globe and the continual emphasis by Chinese authorities that China is part of the developing world.

Having investigated the capabilities and influence of the United States and the emerging powers in the global arena in this and preceding chapters, the major objective of the next chapter is to examine how these capabilities impact on the global structure of power. In other words, the chapter seeks to investigate the polarity of contemporary international politics. 


\section{CHAPTER SIX}

\section{A Uni-interpolar Order?}

\subsection{Introduction}

After the assessment of the capability of the great powers most importantly in terms of their hard power and soft power currencies, an important task of a study of this nature is to analyse how these capabilities transform or impact on the structure of power. Against this backdrop, this chapter seeks to unravel the structure of power in contemporary international politics. The rise of the emerging powers such as China, India, Russia and Brazil has been analysed in the preceding chapter. The argument concerning the relative decline of the United States has also been explored in this study. Therefore, it is interesting now to investigate how the dynamics of today's international politics impact on the structure of power. Furthermore, this chapter investigates the relative importance of other states like the MINT (an acronym for the emerging economies of Mexico, Indonesia, Nigeria and Turkey), Japan and South Korea and non-state actors such as international organizations, multinational corporations and non-governmental organizations in the pattern of global politics. The growing interdependence among states is also explored as well as its attendant multilateralism which manifests especially in the realms of security, energy, economy and environment and, by extension shapes, the relations among states and the policy options of the great powers.

It is the premise of this study that all these characteristics of global politics must be adequately considered in an attempt to offer a model that sufficiently explains polarity in contemporary global politics. Thus, this chapter explores a uni-interpolar order as an alternative model to explain today's global structure of power. It is the position of this study that the traditional models (unipolarity, bipolarity and multipolarity) are not sufficient to explain today's polarity due to the inability of these models to adequately capture the realities of $21^{\text {st }}$ century global politics. Uni-interpolarity is an attempt to synthesise Huntington's uni-multipoalrity and Grevi's interpolarity. Huntington (1999) defined uni-multipolarity as a structure characterised by one super power and some major powers. Grevi (2009) defined interpolarity as "multipolarity in an age of interdependence". This study argues that a hybrid of these two models best captures the major features of contemporary global politics. To this end, this chapter is divided into four major sections. The first section examines the capability of other significant actors such as the 
EU, some state and non-state actors in international politics. The second section investigates the impact of today's interdependence and its attendant multilateralism in global politics. The third section explores the relative edge of the United States despite its declining power and the last section examines uni-interpolarity as an alternative model to explain today's structure of power.

\subsection{Other key players}

\subsubsection{The European Union}

Beyond the United States and the BRIC countries, there are other important players in the international system which do not have either the capacity or will to shape the structure of power in the international system but which play an important role in the dynamics of the power plays in the international arena. Clearly, states are the most important players in international politics. They set the agenda and most importantly make international law. However, recent development in global politics have revealed that influence of states in the global arena has dwindled with the rising influence of non-state actors such as international governmental organisations (IGOs), non governmental organisations (NGOs) and terrorist organisations. This is aptly captured by Zielonka:

So we have a plethora of non-state actors trying to exert their influence in different fields, in different manners and with different results. Obviously not all of these actors can be called power centres, but they are certainly engaged in global power politics in their own different ways. (2008, p. 472)

Against this background, this section seeks to analyse the relative influence of other state actors and non-state actors that influence global politics meaningfully.

The European Union is undoubtedly an important player in international affairs. It is the largest trading bloc in the international system and its policies (most especially agricultural and monetary) have a considerable impact on other states in the global arena (Smith, 2003). In addition, its powerful currency - the euro - is more valuable than dollar. At times the European Union has been considered the United States' junior ally in international affairs. However, the influence of the "region-state" cannot be overemphasised.

The EU employs the use of its soft power attributes such as trade policy, public diplomacy, economic and humanitarian aid rather than military hard power to influence decisions in the global arena (Serfaty, 2011). To this end, it has also successfully used its normative power to 
spread values across the globe. For instance, the EU and the United States account for about 80 percent of international norms and standards that regulate the global market. The hegemony of the euro and dollar largely contributes to this. Even a country like China has adopted the EU regulations and standards in its motor, food, telecommunications and ICT industries (Zielonka, 2008). As the largest trading bloc, the EU employs its economic muscle to promote its norms across the globe. The EU has included democracy as a condition in its trade agreements with countries in Latin America and Africa (Zielonka, 2008). It is worth noting that the EU global spread of norms also manifests in areas such as trade, poverty eradication, environmental protection, labour standards and sustainable development. The EU norms are perceived as alternatives to those of the United States as illustrated in areas where the two actors have opposite agendas on issues such the death penalty, the Kyoto protocol on climate change and International Criminal Court ${ }^{65}$ (Zielonka, 2008). The symbols of the European Union are visible around the world. Some European countries multinational corporations have branches in Africa, Asia and South America; European military and civil forces participate in missions across the world; the European Commission has a delegation in over 120 countries; European literature is widely read and also translated in several languages and the jerseys of the European countries and European major league football teams are widely bought across the world (Renard, 2009).

In 2009, Renard posited that the combined economies of the 27 member states of the European Union accounted for the largest economy in the world and in terms of its military arsenal, the EU possessed substantial military forces and budget to compete in the international arena. The EU is able to exert considerable influence across the globe owing to its very large share of world's $\mathrm{GDP}^{66}$. Its foreign policy instruments include economic, diplomatic, legal and military aspects. In addition, the euro has become the second most important trade currency (Zielonka, 2008). The EU is the largest donor of developmental aid. In 2006 alone, the European Union contributed $€ 2$ billion towards developmental aid. This figure accounted for more than 40 percent of international aid (Zielonka, 2008). The EU foreign policy particularly in the realm of peacekeeping is also noteworthy. The EU has participated in recent times in peacekeeping

\footnotetext{
${ }^{65}$ Unlike the United States, the European Union has ratified the Kyoto Protocol on climate change, it is a signatory to International Criminal Court (ICC) and has abolished the death penalty.

${ }^{66}$ With a GDP of $\$ 15,850,000,000,000$, the European Union ranks second in the countries with the highest GDP in the world. See the World Fact Book at: https://www.cia.gov/library/publications/the-worldfactbook/rankorder/2001rank.html
} 
missions in states such as East Timor, Bosnia, Georgia, Lebanon, Iraq, Afghanistan, Congo and Sudan (Zielonka, 2008). Regarding its economic instruments, the EU imposes sanctions when necessary to promote its interests as exemplified by the fine to the tune of $\$ 1.4$ billion imposed on Microsoft when it failed to comply with European regulations (Zielonka, 2008).

A major challenge that prevents the European Union from significantly transforming its capability to actual influence in global politics is the conflict between the interests of the European Union and the interests of individual member states. Eleven members of the European Union still retain their national currencies rather than the euro and all the member states still enjoy freedom on certain policies such as taxes and employment which enable them to determine the patterns of their economies (Renard, 2009). This contradiction is clearly evident in the bilateral relations of European countries with other countries. European countries sometimes further interests that are beneficial to themselves while jeopardising the interests of the Union. China has often signed deals that are in conflict with the interests of the Union with Germany, France and the United Kingdom. Similarly, Germany and Italy have separate policies in their relations with Russia (Renard, 2009). The contradiction also manifests in the Union's military projection. The armies of the 27 member states only seldom pool resources to carry out operations under the platform of the European Union. In other words, the European Union largely relies on the political will of its member countries to deploy their forces for its operations. Each European country develops its own military capabilities and invests in research and development independently despite an attempt by the European Defense Agency to ensure a common defense strategy among member states (Renard, 2009).

Despite this major challenge, the European Union is a force to be reckoned with in the global arena. It is vocal in major issues in the global arena and the United States often values the support of the European Union to push its agenda in the international system. To this end, Smith (2013) speculated that the EU would remain a major player in the future particularly in the realms in which it excels today, such as environmental policy. Similarly, NIC (2008) forecast that by 2025 , the European Union would have gradually been more able to mobilise its political, economic and military arsenal to assert itself in the pursuit of the European, Western and the global ideals. However, the national interests of the most powerful states that are contradictory to 
the interests of the Union will continue to be a major challenge in the implementation of the EU foreign policy (NIC, 2008).

Aside from the European Union, there are other players which do not fall within the category of a great power but are emerging as forces to be reckoned with. Therefore, it is worth exploring the capabilities of these middle powers in the next section.

\subsubsection{Beyond BRIC: Other emerging states}

Other relevant state actors in the international system include but are not limited to the economic powerhouse of Asia - Japan and South Korea, the latest member of BRICS - South Africa, and the MINT countries - Mexico, Indonesia, Nigeria and Turkey. Japan hugely benefitted from the post-war economic order promoted by the International Monetary Fund (IMF) and General Agreement on Tariffs and Trade. Towards the late 1960s, the Asian economic powerhouse had emerged as the second largest economy. An economy which had been hitherto agrarian metamorphosed into an industrial one as Japan began to produce in enormous quantities products such as iron, motor vehicles, machine tools and electronic devices.

However, towards the end of the 1990s, Japan had slipped into economic recession following a fall in the stock market and the plummeting land prices which had been speculated to skyrocket in that period (Edelman, 2010). The recession continued into the $21^{\text {st }}$ century, and the 2008 global financial crisis also had negative effects on the Asian country economy. With these challenges, China usurped Japan as the second largest economy. Nevertheless, Japan's economy is still relatively robust. With $\$ 5,959,718$ trillion, Japan is the third largest economy in the world (World Bank, 2013). In the military realm, there has been a re-evaluation of Japan's pacific foreign policy informed by the regional security issues in its immediate region, most especially the rise of China and the antagonistic posture of the nuclear-armed North Korea. There have been rising concerns in Japan regarding the North Korean nuclear programme and ships that spy on Japan's territory. Similarly, there is a security dilemma owing to the military rise of China which is complicated by the high levels of secrecy that characterise China's military budget (Hughes, 2009). Accordingly, Japan has strengthened its military arsenal by acquiring the F-2 fighter bomber, KC767 tanker aircraft and by upgrading the E-767 AWACS radar - an antimissile weapon. Japan has also invested in space to strengthen its military capability. For 
instance, between 2003 and 2007, Japan launched four satellites in space which have been helpful in monitoring North Korea's missile bases (Hughes, 2009).

South Korea is another Asian country with huge potential to play a major role in international politics. In 2011, South Korea's GDP by Purchasing Power Parity was ranked twelfth in the world by the CIA World Fact book and its GDP per capita at $\$ 31,700$ was just below Japan's $\$ 34,300$ (Shim \& Flamm, 2012). According to the World Bank, at $\$ 1,129,598$ trillion, South Korea ranks fifteenth in the world economy (World Bank, 2013). In 2011, South Korea attained $\$ 1$ trillion trade volume, a status which had hitherto been achieved by only eight states (Shim \& Flamm, 2012). Its major trading partners are China, Japan, EU and the United States in that order. South Korea is among the leading countries in a wide range of economic sectors such as heavy industries (especially cars, ships and steels), petrochemical, nuclear and electronic industries (Shim \& Flamm, 2012). South Korea is home to some powerful multinational companies such as Samsung, LG, KIA and Hyundai.

At $\$ 31.7$ billion, South Korea ranked twelfth in the countries with the highest military expenditure in 2012 (SIPRI, 2012). The Asian economic powerhouse only spent 2.7 percent of its GDP to achieve this. According to the International Institute of Strategic Studies (IISS) the South Korean military maintains 655,000 troops in peacetime, a figure that is more than double the size of Japan's army (Shim \& Flamm, 2012). There has been a conscious attempt in recent years to harness the South Korean military towards the projection of its influence beyond Korean immediate environment. There have been efforts particularly by the administration of President Roh towards the modernisation of the Korean military arsenal by the procurement of sophisticated weapons such as jet fighters F-X, KD-III destroyers and K2 Black Panther tanks (Shim \& Flamm, 2012). Given, these capabilities, South Korea is no doubt an important player in the international system.

Undoubtedly, Japan and South Korea are allies of the United States. This alliance system is an attempt to check the influence of China and North Korea in the region. Apparently, like the United States, both countries are uncomfortable with the growing economic muscle of China and the military strength, particularly the nuclear arsenal of North Korea. Therefore, the United States values its alliance with Japan and South Korea as a counterweight to China and North 
Korea's influence in Asia. To this end, America serves as South Korea and Japan's military guarantor in times of trouble. Japan, in particular, has no standing army despite its relatively strong economy. It relies heavily on the American military for its safety. This provides a huge strategic advantage for the United States in the region.

Even though South Africa's capability and influence cannot be compared with those of the other members of BRICS, the African player is no doubt an important player in the global arena. It sees itself as representing Africa in a number of forums such as the BRICS, IBSA and the G20. According to Habib (2009), South Africa has promoted African interests in the United Nations, the IMF, World Bank and the WTO. The apparent enormous influence South Africa wields, particularly within the African region, informs why scholars like Habib (2009) have described South Africa as a regional hegemon. Indeed, South Africa has striven to be the major actor that maintains peace and security in Africa. This is not too difficult owing to its status as the only African country with the capacity to produce significant military hardware (Wezeman, 2011) which it supplies to some African countries. Also, South Africa is the largest importer of military weapons in Africa and it was ranked the world's nineteenth largest importer of major arms between 2005 and 2009 (Wezeman, 2011).

Prior to the rebasing of Nigeria's GDP, South Africa was considered the largest economy in Africa and has therefore benefitted from global privileges such as being the sole African member in BRICS, IBSA and G20. With $\$ 384,313$ million, South Africa ranked twenty-eighth in the world's GDP rankings (World Bank, 2013). Despite the recent overtaking of South Africa by Nigeria as the largest economy in Africa, the robustness of South Africa's economy cannot be doubted. South African companies have spread their tentacles to other African countries and foreign investors have been attracted to the South African enabling environment with its liberal values and solid infrastructure.

Jim O'Neill, the Goldman Sach investment banking employee who coined the term BRIC in 2001 (and argued that these countries would emerge as the economic powerhouses in the international economic order) has developed a new set of states: MINT is an acronym for Mexico, Indonesia, Nigeria and Turkey. O'Neill has argued that these countries would shape the future global economic order (BBC, 2014). Similarly, there was a prediction following research 
carried out by SPEAR's magazine and Wealth Insight (a London-based research service) that the MINT countries would outwit the BRICS countries and the G8 in the ranking of states with the most millionaires (Forbes, 2014a). Excluding Turkey, the MINT countries are also leading commodity producers, and are largely benefitting from the high growth in Asia that has pushed up the demand for fuel and raw materials. With the exception of Nigeria, the MINT countries are members of the G20 group of developed and developing countries. The MINT countries share common attributes like large populations and young populations which give them an advantage over other developed and some developing countries like China with ageing populations and which will consequently experience a lower growth rate in the near future (Adibe, 2014). The strategic location of the MINT countries is also fundamental to the success of these countries. Indonesia is geographically located in the centre of China and Australia and it possesses huge resources which have facilitated the rapid rise of its inward foreign direct investment (Adibe, 2014). Mexico is in the centre of the United States and Latin America. Turkey is close to the European Union and also lies between Asia and Africa (Adibe, 2014). Turkey also serves as a sort of gatekeeper to Asia and Africa.

Mexico, which has the largest economy of the MINT countries, at around \$1.2 trillion, has hugely benefitted from its geography. For instance, over the last five years, the country has managed to significantly increase its exports into the US and this has been accompanied by an increase in economic growth, which is currently 3.5 percent per year (Summerfield, 2014). Unlike the debilitating Brazilian policies towards investors, Mexico's free market reforms have attracted investors (Forbes, 2014b). While Nigeria's geographical advantages are less immediately obvious, it has the potential to become the hub of Africa's economy. It has enjoyed an average growth rate of 7 percent since 2000 and there has been a recent rebasing of its GDP. The rebasing of Nigeria's GDP in 2014 reveals the country's GDP as $\$ 509.9$ billion. This has catapulted the African giant as the largest economy in Africa and it is twenty-sixth in the world (Adibe, 2014). The rebasing has also revealed that the Nigerian economy is more diversified than records had shown. The oil sector which had been thought to hugely dominate the economy only accounts for $14 \%$ of the GDP (Adibe, 2014). With this potential, Nigeria has drawn burgeoning investors' attention from across the world. In the words of O' Neill,

In Turkey, visits to white goods manufacturer Beko and Turkish Airlines, the world's fastest growing airline, definitely made me go "Wow", and in Nigeria, I was saying it all the time. The creativity in 
that place is so easy to get enthused about, at least it was for me, and I returned full of excitement about different personal investments I might follow up on. (cited in BBC, 2014)

The relevance of Turkey's strategic location in regional and global politics cannot be overemphasised. It is a large Muslim country located between the Middle East and the CIS states. Thus it serves as a pivotal state for the United States to strengthen its relations with the Muslim world (Serfaty, 2011). Therefore, Turkey's bid for the membership of the European Union is not only important to the vital interests of Europe in the Arab countries but also to the United States, Europe and indeed NATO (Serfaty, 2011).

In today's international system, while states are certainly still the most important actors, there has been increasing interest in the role played by non-state actors. Thus, the next section seeks to explore the relevance of non-state actors in global politics.

\subsubsection{Non-state actors}

According to Haass (2008) globalisation has impacted on the international system in two fundamental ways. Firstly, many cross-border activities take place without the control and knowledge of governments which consequently reduces the influence of the great powers. Secondly, these activities increase the influence of non-state actors such as terrorist organisations and energy exporters. In other words, in recent times the influence of non-state actors such as international governmental organizations (IGO's), non-governmental organizations (NGOs), multinational corporations (MNCs) and terrorist groups is increasingly significant in the international arena to the extent that scholars such as Haass (2008) have reached the conclusion that states have lost their primacy in the international arena. Therefore, the relative influence of these actors is worthy of consideration.

There are numerous IGOs established by states essentially to modify states' behaviour and promote collective goods. Member states are expected to abide by the principles of the international organizations they join. Thus, international organisations limit states' sovereignty as they seek cooperation among member states to resolve problems faced by states in the international system (Ataman, 2003). IGOs create, monitor and enforce international norms and rules on their member states exemplified by the International Atomic Energy Agency (IAEA) which seeks to monitor the conformity of member states to the non-proliferation of nuclear 
weapons treaty (Ataman, 2003). The Organisation of the Petroleum Exporting Countries (OPEC) set a production quota for member states in order to maintain high and stable price of oil in the international market. IGOs such as the United Nations and the European Union have the capacity to impose sanctions on erring member states. The United Nations have imposed sanctions on countries such as Libya, Iraq and Iran. Therefore, IGOs serve as an alternative to the state-centric international system in that they regulate the behaviour of states in order to reduce instability and offer solutions to the world's problems (Rourke, 2007).

However, IGOs also serve as a platform in which states pursue their national interests particularly when such interests do not jeopardise the common interests of member states. The increasing relevance of IGOs has translated into a burgeoning growth in their numbers. Rourke (2007, p. 193) observed that significant IGOs have multiplied from 37 in 1909 to 251 in 2004. Similarly, Goldstein (2008) argued that, depending on how one defines international organisations, the number has grown to around 400. As they are expanding in size, so also are their roles expanding in the international arena. They expand their responsibilities to accommodate new realities, particularly contemporary situations and challenges that arise in the world. Sometimes states form an entirely new IGO to address a new problem (Rourke, 2007). According to Rourke (2007) there are hardly any political issues and governmental responsibilities that are not addressed by IGOs in the $21^{\text {st }}$ century. The European Union can be likened to a supranational organisation with substantive authority over all member states. The EU has most of the institutions of national governments such as presidency and positions for foreign ministers. In addition, it has courts, makes policies and imposes tax on member states (Rourke, 2007). In other words, the EU can be loosely described as a regional state with substantive powers over its member states. Other regions in the world have their regional organisations (with varying degrees of power) such as the African Union (AU) in Africa, the Association of South East Asian Nations (ASEAN) in Asia and the Southern Cone Common Market (MERCOSUR) in South America.

Non governmental organizations (NGOs) are "organizations that operate across national boundaries, that have a membership composed of private individuals, and that do not answer to any government" (Rourke, 2007, pp. 143-144). In other words, NGOs are transnational organisations (made up of individuals) which seek to promote the interests of their members. 
These interests include but are not limited to peace, the environment, human rights, economic, religious and cultural issues. Unlike IGOs, NGOs have specialised functions. For example, the International Air Transport Association focuses on managing the airline companies, Amnesty International deals with human rights, Planned Parenthood for Reproductive Rights focuses on family planning, Transparency International is concerned with the fight against corruption, Greenpeace International and Friends of the Earth International focus on the protection of the environment. In order to be heard, NGOs often spread their tentacles across the globe. For instance, Friends of the Earth International which has its head office in the Netherlands, maintains a presence in 67 countries and Greenpeace International has its headquarters in the Netherlands but maintains offices in 41 countries across the world (Rourke, 2007, p. 144). Like IGOs, the world has experienced an exponential growth of NGOs. Rourke (2007, p. 144) claimed that the number of NGOs increased between 1900 and 2002 from 69 to more than 10,000. Some NGOs with interests of global appeal such as Greenpeace are given observer status in the United Nations and therefore participate in United Nations meetings to discuss issues pertaining to their interests (Goldstein, 2008). Similarly, according to Rourke (2007) over 2,000 NGOs have consultative status in the United Nations. In the words of Ataman:

\footnotetext{
NGOs create and/or mobilise global networks by creating transnational organizations, gathering information on local conditions through contacts around the world, alerting global network of supporters to conditions requiring attention, creating emergency response around world, and mobilizing pressure from outside states. They participate in IGO conferences by mobilizing transnational social movements organizations around issues in IGOs, building transnational social coalitions, raising new issues, supporting IGO development, addressing IGO meetings, submitting documents to governmental organizations' meetings, improving skills in conference diplomacy, and increasing expertise on issues. (2003, p. 47)
}

Similar to national interest groups, NGOs seek to promote their interests through techniques such as creating awareness and calling for support for their causes from the public. They also provide vital information, persuasive arguments and electoral support to policy makers in order to influence domestic and international policy making processes (Rourke, 2007). Thus NGOs have emerged as one of the determinants of a state's foreign policy (Ataman, 2003). NGOs have played a major role in assisting the less developed nations through aid. According to Rourke (2008) the volume of aid from NGOs to the developing countries is about $\$ 10$ billion and due to their perceived transparency, some IGOs and national governments prefer to channel their aid to the developing countries through NGOs. 
Multinational corporations (MNCs) are large companies with their head offices in their home countries and branches in other countries. They are fundamentally agents of economic globalisation. They significantly influence a state's foreign policy without the exception of the great powers and consequently play an important role in international politics (Ataman, 2003). The most influential MNCs are the industrial corporations such as the oil, automobile and the electronics industries (Goldstein, 2008). The financial MNCs, particularly banking, and service MNCs such as McDonalds and DHL are also important (Goldstein, 2008). The strength of the MNCs in the international arena is evident in the resources they have at their disposal. Many industrial MNCs record annual sales to the tune of tens of billions of dollars and the most powerful ones such as Wal-Mart, ExxonMobil and General Motors record annual sales of hundreds of billions of dollars (Goldstein, 2008). Goldstein (2008, p. 338) further observed that in 2006, the GDP of only 35 states outstripped the annual budget of Exxon Mobil. Similarly, Rourke (2007, p. 381) noted that in 2003, Wal-Mart realised \$263 billion in revenue and had 1.5 million workers. The size of the Wal-Mart revenue could be compared with Sweden's GDP and the strength of Wal-Mart employees was more than the population of around 50 countries. MNCs' share of the global foreign direct investment (FDI) is by far the largest (Rourke, 2007). The implication of this is that there are many MNCs which are richer than some nation-states and the influence such MNCs wield in international politics cannot be overemphasised. The powerful MNCs facilitate global interdependence and liberalism. The primary objective of an MNC is profit making. In order to achieve this aim, MNCs strive to maintain a stable international environment which guarantees the flow of capital, trade and movement with little government interference (Goldstein, 2008).

Particularly after the September 11 attacks in the United States, terrorist organisations have received increasing attention in the international system. This is largely because of the destructive tactics of terrorist groups. In expressing their grievances, terrorist organisations often employ tactics like bombing, suicide bombing, kidnapping, shooting and their targets are either civilians or governmental properties. Terrorist organisations seek to promote their agenda beyond the immediate target. They seek wide coverage for their activities. Therefore, they target symbolic government buildings and kill hundreds of civilian people in their operations. Consequently, the destruction and killings have huge and long-term effects on the minds of the wider public. Terrorist organizations like al-Qaeda, ISIS, al-Shabab and Boko Haram are 
notorious for their destructive and dastardly acts which are shown on televisions around the world. An example is the kidnapping of over 200 Nigerian school girls by Boko Haram in 2014 and the ongoing ISIS campaign in Syria and Iraq aimed at taking control of some parts of these countries and establishing an Islamic state. Terrorist organisations are extremely difficult to crush. Even the concerted efforts of the international community have not put an end to terrorist activities. In the words of Camilleri (2002, p. 8) "No amount of wealth, military muscle or technological prowess could erect an effective shield against the actions of desperate men". Indeed, protecting humanity or any state from terrorism seems impossible. This is evident in the concerted efforts of the Israeli state; indeed, "no state goes beyond the measures of Israel in preventing terrorism in security terms, and nevertheless, it's not working" (Chomsky \& Achcar, 2007, p. 9).

Globalisation has enhanced the effectiveness and the reach of terrorist organisations. States cannot adequately monitor the activities in their territories as a result of globalisation. The social media networks such as twitter and facebook have been very useful for terrorist organisations to recruit young individuals and disseminate their ideologies across the globe. The reduction in the cost of transportation and communication has also contributed to the rise of the terrorist groups. In today's world, rather than showing allegiance to their states, some citizens show allegiance to terrorist organisations.

Given the realities of the $21^{\text {st }}$ century, states and non-state actors rely on one another for solutions to common problems. There is growing interdependence and multilateralism in the international system and the next section explores this.

\subsection{Interdependence and multilateralism}

Interdependence among actors is not a new phenomenon in international politics. However, interdependence in contemporary international politics differs from the past in fundamental ways. According to Renard (2009), the current interdependence among states does not only occur in the economic realm, it has functional and systemic attributes. Functional interdependence implies that actors' choices are shaped by international institutions such as the United Nations, World Bank, International Monetary Fund (IMF) and the World Trade Organisation (WTO) which have the capacity to enforce binding rules on international actors in 
order to promote common goods (Renard, 2009). Systemic interdependence requires actors to share the limited resources available on earth to guarantee their survival. Finally, today's interdependence is informed by the concerted efforts of actors in international politics to combat global threats (such as climate change, nuclear proliferation and terrorism) to the existence of the international system (Renard, 2009). "Together, these three forms of interdependence create a historically unique form of comprehensive interdependence, which characterises the second half of the 20th century and will most likely shape the 21st century as well” (Renard, 2009, p. 15).

Today's comprehensive interdependence is accompanied by multilateralism. Goldstein (2008) gave a succinct explanation on the nexus between interdependence and multilateralism. He argued that interdependence connotes a political arrangement and states that trade with each other rely on the political cooperation of each other in order to sustain economic relations. Goldstein (2008) further argued that in the international political economy, interdependence relates more to multilateral relations among states (rather than bilateral relations) in which states rely on the political cooperation of other states to maintain the world markets. Actors (particularly state actors) have realised the importance of tackling the challenges of the $21^{\text {st }}$ century through multilateral arrangements. These challenges are regarded as common global problems necessitating common global action most especially in the economy, the environment, energy and security (Jokela, 2011). In the realm of trade, states interests are intertwined with the World Trade Organisation (WTO). In the sphere of security and defence, state have turned to OSCE and NATO respectively and on climate change, there is the Kyoto protocol (Lazarou et al., 2010). Thus, regional and global organisations are now seen to have a huge role to play in imposing solutions to global problems rather than the narrow and often selfish solutions individual states might want for the myriad of problems threatening humanity (Jokela, 2011).

In order to meaningfully combat these challenges, many long established international institutions are either being reformed or are considering reform (there have been debates and call for reforms in the International Financial Institutions and the United Nations Security Council to accommodate the growing influence of the emerging and regional powers) and the relatively new institutions such as the G20 are becoming more assertive in international affairs (Jokela, 2011). In addition, there was the establishment of the Shanghai Cooperation Organization (SCO) in 2001 which serves as a forum for Russia to counterbalance NATO and BRIC emerged as a 
political organisation in 2009 with the primary objective to provide an alternative to the Western dominated institutions. The bottom line is that the emerging markets are embracing multilateral institutions in which their voices can be better heard than in the traditional Western dominated institutions. The G20 has successfully outwitted the G8 as the major forum for economic cooperation between the largest economies. This was in the realisation of the importance of interdependence, most especially after the 2007-2008 financial crisis. Even though the multilateral posture has been viewed as the policy of the weak states that cannot meaningfully promote their interests in the international arena, the realities of today's world have revealed that even strong states need other states to tackle the dark side of globalisation threatening human civilization.

The emergence of the emerging powers has fundamentally impacted on economic interdependence. The relocation of the manufacturing plants of the developed countries to the developing countries such as China, owing to the relative cheap cost of production in those countries, has significantly impacted on economic interdependence (ISS, 2010). Also, economic relations have been flourishing among the developing countries, most especially among the BRICS countries.

\footnotetext{
The accumulation of huge foreign currency reserves by emerging powers, notably China, has corresponded to the ballooning debt of deficit countries, in particular the United States. Emerging economies have financed spending by the United States on their own exports. Among other factors, such a structural imbalance produced the severe financial crisis that flattened growth, cut credit, and curbed private spending in the developed world. The monetary and fiscal policies of the United States, China, and the EU, among other economic powers, have become more intertwined. The coordination of macroeconomic measures is imperative to sustain global recovery. (ISS, 2010, p. 20)
}

The United States is highly indebted to China. Similarly China heavily relies on the United States market for its manufactured goods and services. According to a Chinese scholar, it is important to understand the duo-phenomenon which means you have on one hand and the other hand. China's influence is rapidly growing with a high volume of trade with other countries, although it is perhaps weakened by its excessive reliance on America's markets. The trade amongst the five BRICS is much lesser than their trade with the West. Even though China's trade with the other BRICS countries is increasing it is dwarfed by China's trade with the United States and the European Union. The economic muscle of China is increasing but this is built around its economic relations with the West. There is an interdependent hegemony which means that the old hegemony like the US and Europe are beginning to rely on the economic growth of 
China and the BRICS countries for their economic prosperity. The economic growth of BRICS has been playing an important role in encouraging global growth. ${ }^{67}$

Domestic politics and policies are having more and more impacts on the international system as illustrated by the 2007-2008 financial crisis that began in the United States and spread to other states in the international system. The industrial pollution of the manufacturing industries in China and the United States (the largest polluters) has massive impacts on climate change and global warming (ISS, 2010). The continued political instability in the Middle East might have an effect on the international cost of oil. The Ukrainian crisis might affect Russia's supply of gas to Europe (a continent which heavily relies on Russian gas). The non-state actors, most especially international organisations such as the United Nations and non governmental organizations are important players in the fight against the threats facing humanity. They set the agenda in international affairs and often collaborate with states in the pursuit of their agendas. This shows the extent to which the international system is characterised by interdependence.

According to Renard (2009) contemporary international politics is characterised by comprehensive interdependence which is "global", "existential" and "complex". The system is global owing to the fact that it involves actors from every part of the world. It is existential because it is characterised by threats such as terrorism and climate change, and it is complex because it involves various forms of interdependence such as economic, cultural and functional. Renard (2009) has called this phenomenon "multi-multilateralism". He argued that multimultilateralism is a remarkable co-operation process characterised by firstly, increasing membership of states in overlapping organizations; secondly, deepening relations among states because of their membership and participation in many forums; and thirdly, the overlapping activities of formal institutions such as the United Nations and the informal forums like the G20 (Renard, 2009). The establishment of the League of Nations has been a watershed in the proliferation of multilateral institutions in today's world (Rourke, 2007). Aided by modern technology and the necessity to tackle global problems, there are now well over 200 hundred intergovernmental organisations (IGOs) with diverse and similar purposes and principles (Rourke, 2007).

\footnotetext{
${ }^{67}$ An interview with Chinese scholar 1
} 
Having examined the comprehensive interdependence and the influence of state and non-state actors in international politics, the question that follows is: to what extent, if at all, does the United States have an edge over the other actors in the international system? The next section addresses this question.

\subsection{The American advantage over the other great powers}

This section seeks to investigate if the United States still has some advantages over the other great powers despite its problems which range from economic to image, coupled with the rise of the other powers. Against this background, Zakaria (2008) argued that the United States economy is still largely robust irrespective of the growing economic clout of the emerging and resurgent powers. The United States has been the world's largest economy since the late $19^{\text {th }}$ century. While there have been predictions of China's possible emergence as the largest economy, most forecasts suggest that by 2025, the United States economy will still double China's economy (Zakaria, 2008). Zakaria's position was reinforced by the National Intelligence Council (2008) in their publication entitled Global Trends 2025: A transformed World. The article argued that if current trends persist, China would remain the second largest economy by 2025. However, there are scholars such as Grevi (2009) and Layne (2012) who hold a contrary opinion. These scholars feel that China might overtake the United States as the largest economy before this period. It is the conviction of the researcher that caution has to be taken when it comes to the prediction of the outstripping of the American economy by another state if past predictions in the 1980s, which never came to reality, are taken into account. The American superiority in the economic realm is perhaps best illustrated by its strength in the industries that will significantly shape the future global economy. For instance, in nanotechnology, no other state comes close to the dominance of the United States. The United States nanocentres outnumber the combined numbers of its next three competitors in Germany, United Kingdom and China and the US has also granted more patents for nanotechnology than the total in the rest of the world (Zakaria, 2008). Furthermore, in biotechnology, American superiority is remarkable. In 2005, with revenue of $\$ 50$ billion, the United States biotech industry was bigger than that of Europe by fivefold and it accounted for 76 percent of the world's biotech revenues (Zakaria, 2008). While there has been growing concern over the United States manufacturing companies continuing to outsource their production to China, the largest income from these 
products comes from designing and distribution which are still largely determined by the United States (Zakaria, 2008). Regarding the prediction of the eventual overtaking of the United States by China as the largest economy in the world in the near future, Nye (2012) was of the opinion that:

... China has a long way to go to equal the power resources of the United States. Even when the overall Chinese GDP passes that of the United States, the two economies will be equivalent in size, but not equal in composition. China would still have a vast, underdeveloped countryside, and it will begin to face demographic problems from the delayed effects of its one-child-per-couple policy. As the Chinese say, they fear the country will grow old before it grows rich. Per capita income provides a measure of the sophistication of an economy. China will probably not equal the United States in per capita income until sometime near the middle of the century. In other words, China's impressive growth rate combined with the size of its population will likely lead it to pass the American economy in total size, but that is not the same as equality. (p.216)

Similarly, in an attempt to analyse the relative strength of the United States particularly in relation to China, an American scholar has observed:

a. It is a one super power world. US is and will long remain only super power, capable of sustaining a complex alliance system in many regions.

b. But we are in or are entering a three-tiered great power subsystem. It is no longer $1+\mathrm{X}$ (one super power + several great powers), but $1+1+\mathrm{X}$ (one super power + 1 potential super power + several great powers). China is the only country that has the potential to be a super power, though it is a long way from getting there.

c. This remains consistent with how I have defined unipolarity. ${ }^{68}$

Being the champion of the global economy which is embedded in its liberal ideals and the major promoter of world's security and stability through its alliance system, America's provision of public goods cannot be matched by any other states (Edelman, 2010). The perceived shared interests in the success of liberalism and the maintenance of security in the international system explains why a large number of states are not motivated to balance the power of the United States (Edelman, 2010). The United States has shown its leadership ability in its readiness to take responsibility in issues of international and global importance. There is evidence of the United States' leadership role in the fight against diseases such as HIV/AIDS and ebola in West Africa, the prevention of nuclear proliferation evident in the Iran nuclear deal, the fight against terrorism

\footnotetext{
${ }^{68}$ An interview with American scholar 2
} 
illustrated by the ongoing campaign against ISIL in Iraq and Syria. The US continues to promote democracy across the globe.

Apparently, a number of states in international politics still welcome the United States' leadership role and according to NIC (2008), states will continue to embrace American leadership on global issues such as climate change, nuclear proliferation and terrorism. The United States leadership is seen as fundamental to ensure countries like China and India are committed to their international obligations towards the reduction of carbon emissions (NIC, 2008). Similarly, many countries will continue to appreciate American leadership in counteracting the proliferation of weapons of mass destruction. The US continues with efforts towards ensuring that these weapons are destroyed in countries with unstable regimes; deterring states from using the weapons; and the attempt to prevent other countries from acquiring these weapons (NIC, 2008). Moreover, there appears not to be the readiness or willingness on the part of the other great powers to shoulder the responsibilities of a global hegemon. China - the closest rival to the United States - has often eschewed such responsibilities and there appears to be a consensus even among China's scholars and analysts that China is not ready for such global roles. Roy (2013) claimed that there has been no interest in China to take on the roles played by the United States in the world. China has shown no interest in becoming a super power. The Chinese elites largely share this predisposition because of two major reasons: firstly, China still needs to concentrate its resources in addressing its myriad of domestic problems rather than diverting such resources towards a global leadership. Secondly, China has learnt from history that aggression is not beneficial. Thus, an attempt by the United States to relinquish its leadership roles on global issues, might create a vacuum which other great powers have shown neither the willingness or the capacity to fill.

Another major edge America has over its competitors is its geographical advantage. Located between two great oceans (Pacific and Atlantic) and two weak and non-aggressive states (Mexico and Canada), in addition to being a peaceful region, America enjoys territorial advantages (Edelman, 2010). The rise of China in Asia has been met with increasing tension in other Asian countries, most especially Japan and South Korea. In Latin America, the rise of Brazil has been marked by Argentina's and Venezuela's growing concern and in the CIS states, Ukraine seeks to challenge Russia. This apparent regional balance of power politics boosts the 
United States' influence across the world and consequently strengthens its alliance system. States such as Japan, South Korea and, to a lesser extent, India, Ukraine and perhaps Argentina seem to welcome the United States to counterbalance the influence of the apparent most powerful states within their respective regions. The United States ties with South Korea and Japan have also been boosted by the growing concern of North Korea's nuclear programme and the leaders of Asian countries have been demanding more American assertiveness in Asia to counteract the rise of China and address the security dilemma in the region (Edelman, 2010). In the words of Slaughter (2009), globalisation has created a networked international system in which international relations such as war, terrorism and counter-terrorism, diplomacy, business and the management of international crisis entails the mobilisation of "international networks of public and private actors". Thus, in this networked age, the state with the most geopolitical connection will be the most important actor because it will find itself in the position of setting the global agenda (Slaughter, 2009). It goes without saying that the United States is the number one benefactor in a networked international system, particularly when one considers the Americanled Atlantic hemisphere which includes Africa, Europe and the Americas and its close ties with the Asian hemisphere (Slaughter, 2009).

Yet another source of America's advantage over its rivals is its energy resources. In terms of the wealth of energy resources, the combination of America and Canada's resources is only outweighed by the Middle East (Edelman, 2010). The United States has the largest reserves of coal in the world as well as large deposits of natural gas and most importantly, oil (the large deposit of oil in Utah, Wyoming and Colorado has been estimated by RAND study to triple the known oil reserves in Saudi Arabia) (Edelman, 2010). Even though there is no consensus in the literature and surveys on the actual quantity of oil in America, there is no doubt that the United States possesses large amounts of oil. Despite the abundance of oil in the United States, America still imports oil across the world, most especially from the Middle East and Africa. While this can be argued to be a long term strategy to preserve the world's most important resource in their territory for future economic gains, there is also an element of political calculation. The United States policy makers have long understood that one way by which the United States can have unassailable influence in the world, is to control all the strategic regions with huge deposits of oil (Chomsky \& Achcar, 2007). 
... there is also the huge strategic importance of the control of oil, which gives the United States decisive leverage over its partners and potential rivals. Japan is a partner whose allegiance to the United States is guaranteed by, among other factors, UScontrol over its oil sources in the Middle East. But China, a potential threat to US global hegemony is checked, too, by the same control. You cannot understand what is happening in global politics if you don't pay attention to the maneuvers involving Russia, China, Japan and the United States around the issues of oil. (Chomsky, 2007, pp. 56-57)

While it can be argued that China has made inroads in the oil-rich regions, particularly in Africa and to a lesser extent in the Middle East, the Asian power influence, particularly regarding the politics of oil in these region, is still significantly dwarfed by Washington's influence. Thus, the United States' advantage over China might even be more significant in the near future with the growing appetite of China for oil.

There are two sources of power that apparently put the United States in a class of its own in that there is no other state close to the United States in terms of the extent to which the global power wields these capabilities. These are the US military arsenal and its soft power. In the military realm, the United States capacity dwarfs that of its closest rivals. This informs why Nye (2012) has argued that the structure of power can be illustrated by three dimensional chess game. The bottom chess board is characterised by transnational relations which are beyond the control of the government. The middle chess board can be likened to economic power which is multipolar and the top chess board is military power which is significantly unipolar (Nye, 2012). The labeling of the top chess board, which is the realm of military power as unipolar, is undisputable when one considers the United States military arsenal (both conventional and nuclear), its military expenditure and its military power projection across the globe. In its projection of global trends till 2025, NIC (2008) argued that the United States superior military capacity will be maintained till 2025 particularly in its capacity to project military power across the entire world. Many states will continue to rely on the military capacity of the United States to guarantee security and a conducive global economic environment, most especially the uninterrupted flow of energy resources across the globe (NIC, 2008).

In the realm of soft power, the United States soft power is completely globalised and no state can match the currencies of the United States soft power. In illustrating the robustness of the United States soft power, Nye pointed out that:

Not only is America the world's largest economy, but nearly half of the top 500 global companies are American, five times as many as next-ranked Japan. Sixty two of the top 100 global brands are American, as well as eight of the top ten business schools... the United States attracts nearly six times 
the inflow of foreign immigrants as second-ranked Germany. The United States is far and away the world's number one exporter of films and televisions programs, although India's Bollywood actually produces more movies per year. Of the 1.6 million students enrolled in universities outside their own countries, 28 percent are in the United States, compared to the 14 percent who study in Britain. More than 86,000 foreign scholars were in residence at American educational institutions in 2002... United States publishes more books than any other country; has more than twice as many music sales as nextranked Japan; has more than 13 times as many Internet website hosts as Japan; ranks first in Nobel prizes for physics, chemistry and economics; places a close second to France for Nobel prizes in literature and publishes nearly four times as many scientific and journal articles as the next runner-up, Japan. (Nye, 2004, pp. 33-34)

The simple implication of this reality is that a large number of people across the globe, speak the American language, eat American food ${ }^{69}$, drink American beverages, watch American movies and listen to American music.

The United States economy remains highly productive. America ranks first in research and development expenditure, university rankings, Nobel prizes, indices of entrepreneurship and ranks fifth in the ranking of the most competitive economy in the world. China has the twentysixth position in this ranking (Nye, 2012).

The next task of this chapter is to examine how the features of contemporary international politics have transformed the immediate post cold war polarity. In other words, how can we label today's power configuration, given the features that have been examined in this study?

\subsection{A uni-interpolar world?}

The fundamental features of contemporary international politics have been discussed above: the emergence of other great powers; the increasing importance of middle powers and non-state actors; the increasing interdependence and its attendant multilateralism; and the relative United States' edge over the other players. The structure of power in today's world must reflect these realities. According to a South African scholar, thirty years ago, it was very straightforward if one wanted to populate the international stage or if one wanted to describe who was on the international stage. The steps are the super powers, the great powers, the middle powers and the small powers. In today's world, the hierarchy is more complicated. It does not only feature states but we have non-state actors competing with states. Al-Qaeda is competing with the super

\footnotetext{
${ }^{69}$ Many people around the world communicate in English and it is perhaps the most influential language in the world. This provides an enormous advantage for America in terms of social and commercial engagement. American food outlets such as McDonalds and KFC are visible across the world.
} 
powers. Thus, the structure of power in contemporary international politics is very confusing, very changeable and very complicated. Lines of communication are varied. The UN Human Rights Council coordinates the Universal Periodic Review which seeks to review the human rights records of all member states of the United Nations. Therefore, all the UN countries participate in the universal periodic review and they submit their reports which typically glorify their records. It is not a simple case of countries addressing each other. This appears to be a multilateral organisation with a life of its own. It also involves the participation of the international NGOs such as International Crisis Group, Human Rights Watch, and Amnesty International. The state domestic performance is now being assessed by multilateral organisations, fellow states and a host of NGOs. They are all exerting considerable influence over a state being assessed. There is also the influence of multinational corporations like Toyota. States are in a class of their own only in that they make international law. ${ }^{70}$

Indeed, uni-interpolariy appears to be the only model that explains all these characteristics of the international system. Uni-interpolarity is a hybrid of Huntington's uni-multipolar and Grevi's interpolar systems. Huntington (1999) argued that uni-multipolarity is a configuration that consists of the power play between a super power and some major powers. In this system, major international decisions are taken by the super power with some of the major powers although the super power has the power to "veto" the decisions taken by the major powers on major international issues. Thus, Huntington's analysis acknowledged the dominance of the United States but ignored the influence of non-state actors and the comprehensive interdependence which significantly influences state's policy options in contemporary international politics. Grevi (2009) argued that interpolarity best describes the coming order. He defined interpolarity as "multipolarity in an age of interdependence". He argued that the international system is characterised by a power transition from the United States to the other great powers which has created a multipolar configuration and a deepening interdependence among states owing to the reality that the security and prosperity of the great powers are significantly connected. Hence, there is interdependence and cooperation among states on economic, security and environmental issues. While Grevi's interpolarity sheds light on today's interdependence and the increasing power of the emerging powers, it downplays the strength of the United States. Against this

\footnotetext{
${ }^{70}$ An interview with South African scholar 1
} 
backdrop, elements of the two models are combined in order to take into account all the major features of contemporary international politics.

Uni-interpolarity is a structure characterised by comprehensive interdependence, a super power with undisputable global influence and some great powers with lesser influence than the super power. In a uni-interpolar system, the extent to which states can embark on unilateral policies is limited than the other structures owing to the functional and systemic interdependence that characterise this structure. However, states seldom take unilateral decisions, particularly if these are linked to economic and strategic interests. Due to its global influence and responsibility, the dominant power has the capacity to take unilateral decisions over the great powers and also has the wherewithal to prevent or frustrate other major powers that take unilateral positions. The super power is also the only state with the capacity and willingness to impose solutions on various crises across the globe. Multilateralism is a key component of a uni-interpolar configuration because there are fundamental issues that cannot be tackled by a single state, not even the dominant power. Security (such as terrorism and nuclear proliferation), economic (such as global recession) and environmental (such as climate change) issues are fundamental issues that confront humanity in the $21^{\text {st }}$ century. These issues cannot be tackled by a single state not even by the most powerful one. Thus, there are multilateral arrangements around these issues to find common solutions to common global problems. The dominant power takes a leadership role in offering solutions to problems across the globe and it is able to mobilise states around the world to fight a common cause.

In a uni-interpolar order there is the tendency of the super powers and some of the great powers to be dissatisfied with the status quo. Thus, there is the likelihood of the super power and great powers to attempt to either tacitly or explicitly distort the status quo. There is the tendency for a struggle for power between the dominant state and the other great powers. The dominant state wants a unipolar world and seeks to pursue foreign policy that can restore a unipolar system. The dissatisfied great powers seek a multipolar world in which their voices can be heard and in which they can take more unilateral decisions to further their interests. According to an American scholar interviewed, the current structure can be defined as one of unbalanced multipolarity. There are several major powers with global influence - the US, China, Russia, Japan, Brazil, India, and the EU - but the United States is by far the strongest. He further argued that 
alternatively, one might describe this as a unipolar system, with the United States as the sole super power followed by a number of important regional powers. ${ }^{71}$ Similarly a Chinese scholar argued that China and the other BRICS still have a long way to go to have a significant impact on the structure of power. According to him, structure of power involves four areas - the control of knowledge production, the control of the financial system, the control of the military and the control of soft power. These are not totally under United States' control as it is declining; however, the BRICS countries still have a long way to go. ${ }^{72}$

In contemporary international politics, the United States is indisputably the number one power as no other power matches the completeness of its capacity. In terms of its global reach, in particular, no state comes close. This provides an opportunity for the United States to take leadership responsibilities in so many issues across the globe ranging from economic, security and health. In counteracting the unilateral tendencies of the other major powers, the United States has successfully mobilised the European countries towards imposing economic sanctions on Russia over its complicity in the Ukranian crisis. Even though there are emerging powers, the United States is the dominant state and together with the Western world it can impose solutions on the myriad of problems facing humanity. ${ }^{73}$ A Chinese scholar described the system as one of "hierarchically organised multipolar structure with a leading power.",74

In an attempt to wield more influence in the international arena, the other major powers, most especially the BRICS countries, have attempted to distort the structure of power in their favour through the establishment of the BRICS. The BRICS was founded with the expectation that such an arrangement would foster a multipolar international order. Thus, recently there was the establishment of the BRICS Bank which is intended to serve as a counterweight to the American dominated financial institutions (IMF, World Bank and WTO). The G20 also serves as a platform for the great powers to exert their influence and popularise their world views. It can be argued that the middle powers and the non-state actors do not significantly impact on the structure of power in the international system in comparison with the super power and great powers. However, the increasing influence of these actors on the world stage cannot be

\footnotetext{
${ }^{71}$ An interview with American scholar 1

${ }^{72}$ An interview with Chinese scholar 1

${ }^{73}$ An interview with Nigerian scholar 2

${ }^{74}$ An interview with Chinese scholar 2
} 
overemphasised, particularly because they determine the power play between the dominant power and the other major actors which seek to increase and maintain their influence across the globe. The European Union, MINT, powerful non-state actors and states such as South Korea, Japan and South Africa are players which are significantly strategic in the balance of power politics among the great powers in terms of economic and strategic interests.

\subsection{Conclusion}

Given the complexity of today's international relations, the traditional models (unipolarity, bipolarity and multipolarity) are insufficient to explain polarity in contemporary international politics. Uni-interpolarity captures the fundamental characteristics of the $21^{\text {st }}$ century international politics which these models have proved adequate to explain. Reference to the existence of a structure of power that is still fluid is common in the literature on polarity. A plethora of scholars have argued that multipolarity will eventually emerge in the near future. This study posits that American power is resilient and one should be wary of projecting the emergence of a true multipolar system. There were several scholarly predictions that did not come to fruition regarding the emergence of a multipolar system following the perception of the American decline and the rise of USSR, China and later Japan in the cold war. The researcher is of the opinion that the future global configuration may remain a uni-interpolar order, metamorphose into a multipolar order or roll back into a unipolar system. In any of these configurations, the United States is likely be the number one state but what differentiates one from another is the rising or declining influence of the United States in relation to the other great powers. In the words of Wohlforth $(2000$, p. 5) "there is always a leader in world politics. If the United States were far weaker than it now is, it would still be number one".

The next and last chapter of this study is the concluding chapter. The task of this chapter is to summarise the major findings of this study, come to a conclusion and finally to consider future polarity in international politics. 


\section{CHAPTER SEVEN \\ Summary and Conclusion}

\subsection{Introduction}

The polarity of the international system determines the pattern of power politics among states, and hence has been the subject of much interest and investigation. While there was consensus among scholars regarding the structure of power prior to the cold war, during the cold war and the immediate period following the cold war, there is no agreement on the current structure of power. This stems from the complexity of contemporary global politics. This study, therefore, is an attempt to investigate the structure of power in contemporary international politics. International politics have always clearly been characterised by the struggle for power among states. Realists argue that humans naturally want to dominate other humans. This human tendency is evident in international relations between states. States strive for economic and military power. Consequently, some states emerge as great powers with global influence, some with regional influence and others remain weak. The relative power capability of states creates polarity in the international system.

An international system dominated by one great power is called a unipolar system. A bipolar system is dominated by two powers and a multipolar system is dominated by more than two. International politics has always reflected one of these patterns. The end of the cold war led to the emergence of the United States as a global hegemony with no competitor in international politics. The United States promoted policies that would ensure the maintenance of a unipolar order. However, in recent years, the relative decline of the United States and the rise of the emerging powers has brought to the fore a debate on the global structure of power. It is against this backdrop that this study investigates polarity in contemporary international politics. by examining the hard and soft power currencies of states that significantly shape the structure of power and the relative influence of the non-state actors.

\subsection{Summary}

Chapter one introduced the study, setting out the research problem, research questions and objective, the methodology, and the method of data analysis. This study aimed to investigate the global structure of power which impacts on how international relations are organised, most 
especially in terms of the politics between the great powers which ultimately impact on the less powerful states. The research problem generated fundamental questions such as to what extent, if at all, the United States maintains its immediate post cold war era dominance in today's world. Does the rise of the emerging powers have a significant impact on the structure of power? How can one describe the polarity of contemporary international politics? This study aimed to explore these fundamental questions.

With regard to the methodology, this research employed qualitative and historical approaches. The choice of these methods was informed by the nature of the research. The study relied on the use of words rather than numbers. It also drew on the power configuration of the past to make inferences on the contemporary structure of power and the likely future polarity. Personal indepth interviews, in addition to internet interviews and raw data from institutes such as SIPRI and World Bank, formed the sources of this study's primary data. The secondary sources included but were not limited to books and journals. Owing to the reliance of the study on indepth interviews, coupled with the difficulty in reaching the targeted interviewees, a purposive sampling method was employed. Content analysis was used to make meaningful analysis of the data gathered.

Chapter two of this study reviews relevant literature and set out the theoretical and conceptual frameworks of the study. Polarity in contemporary international politics has generated considerable interest among scholars of international relations. Some scholars such as Krauthammer (2003), Wohlforth (2002), Walt (2009) and Norrlof (2010) have argued that the international system is unipolar, claiming that no other state matches the completeness of the United States' capabilities. Particularly in the realm of hard power currencies measured in annual military budget and Gross Domestic Product, the United States is by far the number one state in the world. Contrary to the position of the primacists (proponents of unipolarity), some scholars argue that the configuration of the international politics can only be viewed from a multipolar lens.

Scholars like Toje (2010), Xinbo (2010), Layne (1993; 2012) argued that the international system is characterised not only by the United States capability and its influence but by other great powers such as the BRIC countries which challenge the dominance of the United States. 
The emergence of these great powers has resulted in a multipolar structure. These scholars have also pointed to the relative decline of the United States due to the war on terrorism and the financial crisis. They argued that the financial crisis, in particular, has revealed the weakness in the American economic system in that the crisis started in the United States and America was unable to tackle it effectively. Layne (2012) argued that the United States is no longer an economic hegemon. An economic hegemon does not start a global economic crisis; rather it should take the lead in finding solutions to a global economic crisis. However, while the United States struggled to emerge from the crisis, the other great powers, such as China and India, have managed better. This both indicates weakness of the United States economy and provided an opportunity for the other great powers to become more assertive in global affairs. The growing importance of G20 and the BRICS can be understood in this context.

There are also a number of scholars who feel that the realities of $21^{\text {st }}$ century international politics is not adequately captured by the traditional models (unipolarity, bipolarity and multipolarity). It is within this context that Huntington's uni-multipolarity, Haass's nonpolarity and Grevi's interpolarity can be located. Huntington (1999) argued that the international system was uni-multipolar. He defined uni-multipolarity as a system with one super power and several major powers. He argued that major issues in the international arena are determined by the super power in collaboration with some of the major powers. However, the super power has the capability to reject the decisions or actions of the major powers. Huntington's analysis acknowledged the edge the United States has over the other great powers in terms of its capability. It also took into cognisance the rise of the emerging powers which are becoming more assertive in international politics. For Haass (2008) the configuration of the international system can be described as nonpolarity. Nonpolarity is characterised by many power centres. He argued that states have lost their primacy in the international arena with the rise of non-state actors which wield significant power in the international system. Thus, in today's world, both state and non-state actors wield influence at the global arena. International governmental organisations (IGOs), non governmental organisations (NGOs), multinational corporations (MNCs) and militias are all striving for influence in global politics and consequently reduce the influence of states. 
For Grevi (2009) the system is interpolar. He defined interpolarity as "multipolarity in the age of interdependence". Grevi highlighted the power transition from the United States to the other rising great powers resulting in a multipolar order. He further argued that rather than there being a conflictual order, there will be collaboration among states due to the growing interdependence in today's world. He identified economy, environment and security issues as factors that facilitate interdependence among states. For instance, environmental damage like climate change, security issues like nuclear proliferation and terrorism, and economic crisis like recession require the collaborative efforts of states in the international system. No single state, no matter how powerful, can tackle these global problems alone.

The study utilised the balance of power and multilateralism as its theoretical and conceptual frameworks respectively. The rise of the emerging powers and the relative decline of the United States have necessitated the balance of power politics among the great powers. The establishment of BRICS and the BRICS bank, the standstill in the United Nations over major international issues such as the Syrian war, the rise in the military budget of countries such as China, can all be understood within this context. Despite the apparent balance of power politics in the international relations between the great powers, a degree of multilateralism in today's international politics is evident in the ever-increasing role of various international institutions which modify states' behaviour to conform to international law. Today's multilateralism also results from the common threats facing humanity such as environmental, security and economic problems which require common solutions. It is with the realisation that no single state, no matter how powerful, can effectively combat these issues that states have collaborated with one another to find common solutions to these common global problems.

Chapter three of this study is a historical account of polarity prior to the $21^{\text {st }}$ century. Multipolarity was full blown in the $18^{\text {th }}$ and $19^{\text {th }}$ centuries. The multipolar power configuration determined the pattern of relations among the great powers and it was also characterised by a balance of power in order to prevent the emergence of an empire with capabilities beyond the other great powers combined. Europe was the centre of world politics in this period and all the great powers were European countries. For instance, between 1815 and 1914, the great powers were Great Britain, France, Russia, Prussia/Germany, Austria-Hungary, Italy and the Ottoman Empire/Turkey. Entering the $20^{\text {th }}$ century, the United States and Japan emerged as great powers 
which significantly shifted the eurocentric great power politics to more global great power relations. Tension between the great powers resulted in the first and second world wars. These wars ravaged and devastated the European countries resulting in the ascendance of the United States and the Soviet Union to the status of super powers with capabilities that no other great power or combination of great powers could match.

The gap between the United States and the USSR, on the one hand, and the other great powers, on the other, was so huge that a bipolar configuration emerged in the period immediately following the Second World War. Between 1945 and 1989 world politics reflected the pattern of interactions between the two super powers as each tried to outwit the other in their sphere of influence across the globe. This created a cold war whereby, in an attempt to establish global hegemony, the two superpowers fought proxy wars across the globe and strove for influence most especially in Asia, Africa and Latin America. Along with their huge military arsenal and economic prowess, the super powers also had ideological appeal..The United States sought to promote liberalism across the world while the Soviet Union endeavoured to spread communism. The Soviet economy was ultimately unable to sustain the arms race that characterised the war and this led to the end of the war in 1989 and the consequent disintegration of the Soviet Union.

Following the demise of the USSR, the United States emerged as the undisputed global hegemon in the international system. Its capacity and influence across the globe was so immense that scholars and observers of international politics were quick to describe the global structure of power as a unipolar system. The period immediately following the cold war marked PaxAmericana. The American global influence was unprecedented. No other state in history has enjoyed dominance to the extent America has.. Thus, the United States was able to spread liberalism across the world without much of a challenge. It also utilised the most important international institutions to promote its interests around the world. Due to its influence in the establishment and the maintenance of the world's major international institutions, the United States was able to promote its interests via international organisations such as the United Nations, the IMF and the World Bank. However, following the United States war on terrorism in Afghanistan and Iraq, and the 2008 financial crisis with the consequent rise of the other countries, the dominance of the United States across the globe has diminished and the global structure of power is changing. 
Chapter four investigated the United States capabilities both in terms of its hard power and soft power. The chapter described dominance of the United States in all components of power leading ultimately to its dominance in international affairs. At the end of the cold war, with the disintegration of the Soviet Union, the United States emerged as the sole super power. Thus, in the period immediately following the cold war, Washington's power and influence on the international system was exceptional and it could singlehandedly determine events and decisions of international consequence. In terms of its economic strength, the United States is clearly the largest economy with a Gross Domestic Product that doubles that of its closest rival (China). Despite a little more slowly than one would expect from a super power, America has been able to recover from the economic crisis and there have been positive reports on the American economy in recent times. This contradicts the pessimism expressed by some observers on the American economy vis-à-vis the rise of the BRIC countries. American military dominance is unquestionable. With a military budget of $\$ 682$ billion, which accounts for about $40 \%$ of the world's total military budget, Washington's expenditure is the equivalent of the sum of the military expenditure of the next 14 countries.

America's dominance is also visible in terms of its far-reaching soft power. Countries around the world admire the American culture and values. The American popular culture, most especially the entertainment industry (hip hop and R\&B music, Hollywood movies), attracts audiences across the world. American artists are hugely popular and also promote the American culture. The global reach of the American fast food and drink industries, particularly McDonalds, KFC and Coca-Cola, is also exceptional. American universities pride themselves in attracting the most foreign students who imbibe the American culture while studying and when they return to their countries to assume key political positions, they often hold moderate and positive views on their countries' relations with the United States. American liberalism is a further source of attraction with its values of democracy and views on human rights. The end of the cold war was a triumph of liberalism over communism and provided a platform for the United States to spread its political values aided by the western dominated institutions such as the IMF, World Bank and WTO. These institutions became agents of globalisation which promoted Washington's ideals around the world. 
Given the soft power capabilities of the United States, the chapter explored the extent to which the super power wielded this power in strategic regions of the world, most especially in Africa and the Middle East. The study found that in Africa only the American image had not significantly declined in the post 9/11 world. America has also made conscious attempts in engaging African countries through its soft power packages such as AGOA, MCC, AFRICOM and PEPFAR. Among these, PEPFAR is the most widely applauded due to the programme's success in combating the HIV/AIDS epidemic. In the Middle East, while some countries admire elements of American culture, its science and technology, they despise its foreign policy evident in their opposition to American interference and intervention in Muslim countries. America has endeavoured to improve its image in this region through the establishment of media outlets like Hi magazine and Radio Sawa and programmes such as MEPI. However, these initiatives have not substantially boosted the eroded US image. The last section of the chapter explored the debate around Washington's decline. There is no gainsaying the fact that the decline of the United States is real. However, it must be understood in relative terms. America's decline stems from two major significant events in the post-cold war period - the 2003 war on terrorism and the 2008 financial crisis - which resulted in the rise of the other countries and the relative decline of the United States. It is the conviction of this study that, despite its decline, America still outshines its closest rivals in many respects.

Chapter five examined the capability of the emerging powers of BRIC. The relative decline of America has catapulted new actors such as India and Brazil to great power status and stimulated the resurgence of old great powers like Russia and China. Thus, an investigation into the power profiles of these countries vis-à-vis that of the United States is fundamental in an attempt to describe the structure of contemporary international politics. The BRIC countries are by far the most important rising powers when one considers the remarkable economic growth recorded in these countries and the resilience of their economies (evident in their quick recovery from the financial crisis). BRIC was established as a counterweight to American hegemony in the international system and there have been efforts on the part of its members to distort the balance of power in their favour as illustrated in Russia and China's veto power in the United Nations and the recent establishment of the BRICS bank as an alternative to the western dominated institutions of the IMF and the World Bank. 
While Brazil is not a global military power, its economic capability is notable. It ranks seventh in the world's GDP ratings and has maintained impressive economic growth. Brazil largely employs its soft power currencies to flex its muscles across the globe. Brazil's pacificism and popular culture, most importantly its football, samba and carnivals, are admired across the world. Unlike Brazil, Russia is a hard power state. Russia is the world's third largest military spender. It owns the world's largest nuclear warheads, possesses a sophisticated military arsenal and it is a major military supplier to other states. Russia accounts for the eighth largest economy in the world and has recorded a remarkable growth rate particularly between 2000 and 2008. While Russia may not have the capacity to wield its soft power globally, these do have an influence in the CIS states. Its natural resources and finished goods, its culture, language, movies, and music are popular in its immediate region.

India is the tenth largest economy in the world and has maintained an impressive growth rate since the 1980s. It ranks eighth in the world in terms of military budget and it is also a nuclear power. India is a soft power state with a cultural reach that goes beyond its immediate region. The presence of India's culture is visible in faraway countries like Iran and South Africa. India's Bollywood accounts for the world's largest production of films. India's Buddhism is a major religion in the world and it draws a huge number of members from countries like China, Vietnam, Korea, Thailand, Japan and Cambodia.

China is the most important BRIC actor and it is the only player with reasonable capability to compete with the United States. China is the second largest economy in the world. Its impressive economic growth rate since the 1980s cannot be compared with any other major country in the world. China has become the world's manufacturing warehouse and many western industries are moving their factories to China for lower production costs. Its economy has shown resilience illustrated by the financial crisis and it has been predicted in many quarters that the China's economy will in the very near future surpass the United States to become the largest economy in the world. China has the largest number of people in its military forces and it is ranked second in the world in terms of military expenditure. The Chinese government has also made efforts to boost China's soft power largely through Confucianism and the Chinese economic model. There are hundreds of Confucius Institutes around the world and Chinese economic model has been viewed in some quarters as an alternative to Western liberalism. 
China has been able to attract certain African and Middle Eastern countries with unconditional loans which are different to the Western loans that are accompanied by conditions. In addition, the Chinese policy of sovereignty and non-interference in the internal affairs of other states is also popular with these regions. China's primary concern is economic relations and it will have relations with any country, irrespective of their domestic politics (such as high levels of corruption, bad governance). China's economic growth and its strong government is admired by authoritarian regimes such as Mugabe's Zimbabwe and Bongo's Cameroon in Africa. The middle income population in the Middle East largely consumes cheap and affordable Chinese products. This has remarkably improved their purchasing power. China has also attracted the Middle Eastern countries with its aid and assistance, most especially in the health and educational sectors. There are scholarships to Chinese universities available to some Middle Eastern students such as in Saudi Arabia. The Asian power also sends medical workers to where there are shortages such as in Yemen.

Chapter six of this study is the final substantive chapter and has as its primary objective labelling the global structure of power given the characteristics of contemporary international politics. The chapter outlines the important features of today's world and argues that aside from the United States and the BRIC countries, there are other fundamental state and non-state actors with meaningful influence. An academic exercise of this nature would not be complete without examining the capabilities of these players. The European Union is a region state. It is the largest trading bloc in the world and its foreign and monetary policies influence the options of other states. The combined GDP of the states in the European Union is the largest in the world. The European Union is undoubtedly a powerful force to be reckoned with in the international arena. The strength of the Union lies in its supranational attributes. However, its major weakness is the tendency of the member states, especially the powerful ones, to promote their individual interests rather than the collective interests of the Union in their international relations with other states.

The MINT countries have also emerged as important players in the international system. According to Jim O'Neill, these countries will shape future global economic order. The major strengths of the MINT countries lie in their strategic locations and their youthful population which is essential in promoting future economic growth. Except for Turkey, the MINT countries are leading commodity producers and except for Nigeria, they are all members of G20. Analysts 
will watch with keen interest whether the MINT countries will eventually form a bloc like the BRICS, given the potential of these countries and the benefits that might accrue to the member states of such a bloc. In addition to these countries, the Asian countries of Japan and South Korea are important players in global politics. These Asian giants have a robust economy and are home to very powerful multinational corporations, particularly in the manufacturing industry. They are Western allies and they serve as a check to China and North Korea's growing influence in the region. To this end, both countries have been increasingly boosting their military arsenals. South Africa is an important player in the region of Africa and its influence in the region is remarkable. It is the only African representative in the BRICS, IBSA and G20.

Today's power diffusion has led to the emergence of powerful non-state actors in the scene of international politics. Many IGOs, NGOs, MNCs and even terrorist organisations are becoming more and more assertive in the international arena. The activities of these actors shape the behaviour of states. This gives the impression that states are not as powerful as they used to be. Their primacy is now being challenged by these non-state actors. Given the multiplicity of power centres in today's world and the interdependence and multilateralism which characterise the contemporary international system, the description of the contemporary global structure of power must adequately capture these realities. To this end, the chapter argues that the traditional models of unipolarity, bipolarity and multipolarity are insufficient to explain the characteristics of today's world. Thus, polarity in contemporary international politics can be viewed from the prism of a hybrid of uni-multipolarity and interpolarity. The researcher labels this synthesis uniinterpolarity.

\subsection{Conclusion}

Polarity in contemporary international politics has generated debates among scholars and observers of international politics. The contribution of this thesis to the debate is the proposal of the concept of a hybrid of uni-multipolarity and interpolarity. This is labeled uni-interpolarity. Uni-interpolarity captures all the major features of contemporary international politics. Uniinterpolarity is characterised by comprehensive interdependence, a super power with global influence, some great powers with lesser influence than the super power and powerful non-state actors. Contemporary international politics is characterised by: firstly, the emergence and resurgence of new and old great powers respectively, secondly, the middle powers and non-state 
actors becoming more assertive; thirdly, an increasing interdependence and multilateralism in international relations among actors; and finally, the United States' relative decline and its advantage over the other actors.

Uni-interpolarity is different from unipolarity because in a unipolar order, there is only one major power and some minor powers. In contrast, uni-interpolarity recognises the existence of many major powers in the international system. It is different from bipolarity because in a bipolar configuration, there are only two major powers and global politics reflects the choices and decisions of the two major powers. Uni-interpolarity on the other hand argues that there are many power centres in the globe and, unlike unipolarity and bipolarity, uni-interpolarity indicates that some non-state actors are becoming more assertive and significantly influence world's events in today's world. Uni-interpolarity differs from uni-multipolarity in that the latter does not recognise contemporary international relations deepening interdependence and the accompanying multilateralism. In addition it does not analyse the role of non-state actors in the international system. Uni-interpolarity differs from non-polarity because non-polarity gives too much power to the non-state actors and substantially understates the power of state actors. Uniinterpolarity differs from interpolarity in that interpolarity understates the power of the United States and exaggeration of other great powers capabilities in an age of interdependence.

Given the realities of today's world, uni-interpolarity better captures the structure of power than any other model. As a result of the comprehensive interdependence, there are fewer tendencies for states to employ unilateralism to promote their interests. Today's comprehensive interdependence motivates states to embrace multilateralism rather than unilateralism. However, this does not necessarily imply that states will completely eschew unilateralism. It only implies that the extent to which states will employ unilateralism is limited. In fact, states, particularly the great powers, will continue to adopt the go-alone strategy in promoting some of their core or strategic interests which are in conflict to the common interests of the global community. In this case, the super power has an advantage over other states to embark on a unilateral posture in the promotion of its interests owing to its superior capability.

Thus, despite the decline of the United States and the rise of the emerging powers, polarity in today's world can conveniently be described as uni-interpolar. The question this generates is to 
what extent this system will be maintained into the future. It is the contention of this researcher that there is likely to be one of three scenarios in the near future: firstly, the strengthening of a uni-interpolar order; secondly, the emergence of a true multipolar order which will only become a reality if the United States continues to decline and the emerging powers continue to rise; thirdly, a return to a unipolar order. The feasibility of this order stems from the fact that United States power has proven to be resilient over the past 60 decades. In the past, there had been predictions of American decline and the emergence of multipolarity following the rise of USSR, China and Japan. However, none of those predictions have come to fruition. For now, polarity in contemporary international politics is unambiguously uni-interpolar. 


\section{Bibliography}

\section{Books}

Alterman, J. (2009). China's Soft Power in the Middle East. In C. McGiffert \& J. Bean (Eds.), Competition and Cooperation in the Developing World (pp. 63-76). Washington DC: Centre for Strategic and International Studies.

Amin, S. (2006). Beyond US Hegemony? Assessing the Prospects for a Multipolar World. London: Zed Books.

Aron, L. (2013). The Political Economy of Russian Oil and Gas. American Enterprise Institute for Public Policy Research.

Baxter, K., \& Akbarzadeh, S. (2008). US Foreign Policy in the Middle East: The Roots of AntiAmericanism. New York: Routledge.

Blum, W. (2003). Killing Hope: US Military and CIA Interventions since World War II. London: Zed Books.

Bryman, A. (2004). Social Research Methods (2 ${ }^{\text {nd }}$ ed.). New York: Oxford University Press.

Bull, Hedley. (1977). The Anarchical Society: A Study of Order in World Politics. London: The Macmillian Press Limited.

Bullen, R. (1979). France and Europe, 1815-48: the Problem of Defeat and Recovery. In A. Sked (Ed.), Europe's Balance of Power: 1815-1848. (pp.122-144). London: Macmillan.

Busha, C., \& Harter, P. (1980). Research Methods in Librarianship: Techniques and Interpretation. New York: Academic Press.

Calvocoressi, P., Wint, G., \& Pritchard, J. (1972). The Penguin History of the Second World War. London: Penguin.

Chomsky, N., \& Achcar, G. (2007). Perilious Power: The Middle East and US Foreign Policy: Dialogues on Terror, Democracy, War and Justice. London: Penguin. 
Cooke, J. (2009). China's Soft Power in Africa. In C. McGiffert \& J. Bean (Eds.), Competition and Cooperation in the Developing World (pp. 27-44). Washington DC: Centre for Strategic and International Studies.

Cooke, J., \& Morrison, J. (2009). A Smarter US Approach to Africa. In J. Cooke, \& J. Morrison (Eds), US Africa Policy beyond the Bush years: Critical Challenges for the Obama administration. Washington, D.C: Centre for Strategic and International Studies.

Cox, R. (1987). Production, Power, and World Order: Social Forces in the Making of History (Volume 1). New York: Columbia University Press.

Dakin, D. (1979). The Congress of Vienna, 1814-1815, and its Antecedents. In A. Sked (Ed.), Europe's Balance of Power: 1815-1848. London: Macmillan.

Diaz, L., \& Brainard, L. (Eds.). Brazil as An Economic Superpower?: Understanding Brazil's Changing Role in the Global Economy. Washington DC: Brookings Institution.

Dunbabin, J (1994). The Cold War: The Great Powers and their Allies. New York: Longman.

Evans, G., \& Newnham, J. (1908). The Penguin Dictionary of International Relations. London: Penguin.

Friedman, G. (2009). The Next 100 Years: A Forecast for the Late $21^{\text {st }}$ Century. New York: Anchor Books.

Fukuyama, F. (1992). The End of History and the Last Man. London: Penguin.

Goldstein, J., \& Pevehouse, J. (2008). International Relations ( $8^{\text {th }}$ ed.). New York: Pearson Longman.

Hobsbawn, E. (1962). The Age of Revolution: 1789-1848. London: Abacus

Hobsbawn, E. (1987). The Age of Empire: 1875-1914. London: Abacus.

Hobsbawn, E. (1994). The Age of Extremes: 1914-1991. London: Abacus.

Jervis, R. (2007). Explaining the Bush doctrine. In R. Art \& R. Jervis (Eds.). International Politics: Enduring Concepts and Contemporary Issues ( $8^{\text {th }}$ ed.). New York: Pearson Longman. 
Kaarbo, J. \& Ray, J. (2011). Global Politics (10 ${ }^{\text {th }}$ ed.). Boston: Wadsworth.

Kegley, C., \& Wittkopf, E. (1991). American Foreign Policy Pattern and Process $\left(4^{\text {th }}\right.$ ed.). New York: St. Martin's Press.

Kennedy, P. (1988). The Rise and Fall of the Great Powers: Economic Change and Military Conflict from 1500 to 2000. London: Unwin Hyman Limited.

Ketelbey, C. (1929). A History of Modern Times from 1789 ( $5^{\text {th }}$ ed.). New York: Oxford University Press.

Khanna, P. (2009). The Second World: Empires and Influence in the New Global Order. New York: Random House Trade Paperbacks.

LaFeber, W. (1994). The American Age: U.S. Foreign Policy at Home and Abroad since 1896. (Volume 2) ( $2^{\text {nd }}$ ed.). New York: W.W. Norton \& Company.

Lewis, P. (1992). Superpower Rivalry and the End of the Cold War. In A. McGrew \& P. Lewis (Eds.), Global Politics: Globalization and the Nation-State. Cambridge: Polity Press.

Martinez-Diaz, L., \& Brainard, L. (2009). Brazil: The "B" Belongs in the BRICS. In L. Brainard \& L.Martinez-Diaz (Eds.), Brazil as an Economic Superpower? Understanding Brazil's Changing Role in the Global Economy (pp. 1-13). Washington: Brookings Institution.

McGrew, A. (1992). Superpower Rivalry and US Hegemony in Central America. In A. McGrew \& P. Lewis (Eds.), Global Politics. Cambridge: Polity Press.

Mearsheimer, J. (2001). The Tragedy of Great Power Politics. New York: W.W Norton \& Company.

Morgenthau, H. (1985). Politics among Nations: The Struggle for Power and Peace. Brief edition (Revised edition). New York: McGraw-Hill.

Neuman, W. (1994). Social Research Methods: Qualitative and Quantitative Approaches (2 ${ }^{\text {nd }}$ ed.). Massachusetts: Allyn and Bacon.

Neuman, W. (2011). Social Reserch Methods: Qualitative and Quantitative Approaches ( $\left.7^{\text {th }} \mathrm{ed}.\right)$. Boston: Allyn \& Bacon.

Newnham, J., \& Evans, G. (1998). The Penguin Dictionary of International Relations. London: Penguin Books Ltd. 
Nieburg, P., \& Morrison, J. (2009). The Big US Leap on HIV/AIDS in Africa: What is the Next Act? In J. Cooke \& J. Morrison (Eds.), US Africa Policy beyond the Bush Years: Critical Challenges for the Obama Administration (pp. 34-61). Washington: Centre for Strategic and International Studies.

Norrlof, C. (2010). America's Global Advantage: US Hegemony and International Cooperation. New York: Cambridge University Press.

Nye, J. (2004). Soft Power: The Means to Success in World Politics. New York: Public Affairs.

Potter, D. (1992). Superpower Rivalry in South Asia and Southern Africa. In A. McGrew \& P. Lewis (Eds.), Global Politics. Cambridge: Polity Press.

Ray, J. (1979). Global Politics. Boston: Houghton Mifflin Company.

Robertson, C. (1975). International Politics since World War II: A Short History (2 ${ }^{\text {nd }}$ ed.). New York: John Wiley \& Sons.

Rosenau, J., \& Durfee, M. (1995). Thinking Theory Thoroughly: Coherent Approaches to an Incoherent World. Colorado: Westview Press.

Rourke, J. (2007). International Politics on the World Stage (11 ${ }^{\text {th }}$ ed.). New York: McGraw-Hill.

Roy, D (2013). Return of the Dragon: Rising China and Regional Security. New York: Columbia University Press.

Rugh, W. (2006). American Encounters with Arabs: The Soft Power of US Public Diplomacy in the Middle East. Westport: Greenwood Publishing.

Shennan, J. (1995). International Relations in Europe: 1689-1789. New York: Routledge.

Trinkunas, H. (2014). Brazil's Rise: Seeking Influence on Global Governance. Brookings: Latin America Initiative Foreign Policy.

Weber, R. (2004). Content Analysis. In S. Clive (Ed.), Social Research Methods: A reader (pp.117-127). New York: Routledge.

Woodruff, W. (1981). The Struggle for World Power: 1500-1980. New York: St. Martin's Press.

Zakaria, F. (2011). The Post-American World and the Rise of the Rest. London: Penguin. 


\section{Journal Articles}

Abdallah, A. (2003). Causes of Anti-Americanism in the Arab World: A Socio-Political Perspective. Middle East Review of International Affairs, 7(4), pp. 62-73

Adibe, J. (2014). MINT, Re-Based GDP and Poverty: A Commentary on the identity crisis in Africa's "Largest" Economy. African Journal of Business and Economic Research 9(1), 119-134.

Akinola, A., \& Tella, O. (2013). Boko Haram Terrorism and Nigeria's Security Dilemma: Rethinking State's Capacity. International Journal of Innovative Social Sciences and Humanities Research, 1(3), 70-78.

Amann, E. (2005). Brazil's Economy under Lula: The dawn of a new era? World Economics, 6 (4), 149-169

Ataman, M. (2003). The Impact of Non-State Actors on World Politics: A Challenge to NationStates. Alternatives: Turkish Journal of International Relations, 2(1), 42-66

Baylouny, A. (2005). Alhurra, the Free One: Assessing U.S. Satellite Television in the Middle East. Strategic Insights, 4(11)

Bertonha, J. (2010). Brazil: An Emerging Military Power?: The Problem of the Use of Force in Brazilian International Relations in the $21^{\text {st }}$ Century. Rev.Bras. Polit.int. 53(2), 107-124.

Bodomo, A. (2009). Africa-China Relations: Symmetry, Soft Power and South Africa. The China Review, 9(2) 169-178.

Brooks, S., \& Wohlforth, W. (2002). American Primacy in Perspective. Foreign Affairs, 81(20), 20-33.

Carbone, M. (2004). The Millennium Challenge Account: A Marginal Revolution in US Foreign Aid Policy? Review of African Political Economy, 31(101), 536-542.

Camilleri, J. (2002). Terrorism, Anti-Terrorism and the Globalization of Insecurity. Arena Journal, 19, 7-19.

Chen, S., \& Feffer, J. (2009). China's Military Spending: Soft Rise or Hard Threat? Asian Perspective, 33(4), 47-67. 
Cho, Y., \& Jeong, J. (2008). China's Soft Power: Discussions, Resources, and Prospects. Asian Survey, 48(3), 453-472.

Cox, M. (2004). Empire, imperialism and the Bush doctrine. Review of International Studies, 30, 585-608.

Das, G. (2006).The India Model. Foreign Affairs, 85(4), 2-16.

De Lima, M., \& Hirst, M. (2006) Brazil as an intermediate state and regional power: action, choice and responsibilities. International Affairs, 82(1), 21-40.

Ding, S. (2008). To build a "Harmonious World": China's Soft Power Wielding in the Global South. Journal of Chinese Political Science, 13(2), 193-213

Dominquez, J. (1997). U.S. - Cuban Relations: from the Cold War to the Colder War. Journal of Interamerican Studies and World Affairs, 39(3), 49-75.

Esterhuyse, A. (2008). The Iraqization of Africa? Looking at AFRICOM from a South African Perspective. Strategic Studies Quarterly, 2(1), 111-130.

Fijałkowski, Ł. (2011). China's 'soft power' in Africa? Journal of Contemporary African Studies, 29(2), 223-232.

Gardels, N. (2005). The Rise and Fall of America's Soft Power. New Perspectives Quarterly, 22 (1), 6-19.

Gill, B., \& Huang, Y. (2006). Sources and limits of Chinese soft power, Survival: Global Politics and Strategy, 48(2), 17-36.

Haass, R. (2008). The Age of Nonpolarity: What will Follow US Dominance. Foreign Affairs 87(3), 44-56.

Habib, A. (2009). South Africa's foreign policy: hegemonic aspirations, neoliberal orientations and global transformation. South African Journal of International Affairs, 16(2), 143-159.

Hackbarth, J. (2009). Soft Power and Smart Power in Africa. Strategic Insight, 8(1), 1-19.

Hancock, K. (2007). Russia: Great Power Image versus Economic Reality. Asian Perspective, 31(4), 71-98.

Harris, J. (2005). Emerging Third World powers: China, India and Brazil. Race \& Class 46 (3), $7-27$. 
Hill, F. (2006). Moscow Discovers Soft Power. Current History, 105(693), 341-347

Huang, Y. \& Ding, S. (2006). Dragon's Underbelly: An Analysis of China's Soft Power. East Asia, 23(4), 22-44.

Hughes, C. (2009). Japan's Military Modernisation: A Quiet Japan-China Arms Race and Global Power Projection. Asia-Pacific Review, 16(1), 84-99.

Hunter, A. (2009). Soft Power: China on the Global Stage. Chinese Journal of International Politics, 2, 373-398.

Huntington, S. (1999). The Lonely Super Power. Foreign Affairs, 78(2), 35-49.

Ifeka, C. (2010). War on 'terror': Africom, the kleptocratic state and under-class militancy in West Africa-Nigeria. Concerned Africa Scholars Bulletin, 85, 30-49.

Ikenberry, G., Mastanduno, M., \& Wohlforth, W. (2009). Unipolarity, State Behaviour and Systemic Consequences. World Politics, 61, 1-27.

Isike, C., Uzodike, U., \& Gilbert, L. (2008). The United States Africa Command: Enhancing American security or fostering African development? African Security Review, 17(1), 20-38.

Jentleson, B. (2007). America's Global Role after Bush. Survival: Global Politics and Strategy, 49(3), 179-200.

Jervis, R. (2005). Why the Bush Doctrine Cannot Be Sustained. Political Science Quarterly, 120(3), 351-377.

Kabundi, A. (2009). Synchronisation between South Africa and the U.S: A Structural Dynamic Factor Analysis. South African Journal of Economics, 77(1), 1-27.

Kalashnikov, A. (2011). Differing Interpretations: Causes of the Collapse of the Soviet Union. Constellation, 3(1), 75-86.

Keling, M., Shuib, S., \& Ajis, M. (2009). The Emergence of India as New Military Power: Threat or Opportunity to Southeast Asia? Asian Social Science, 5(4), 22-31.

Krauthammer, C. (2002). The Unipolar Moment Revisited. National Interest, 70, 5-17. 
Kraxberger, B. (2005). The United States and Africa: Shifting Geopolitics in an "Age Of Terror". Africa Today, 52 (1), 47-68.

Ladwig, W. (2010). India and Military Power Projection: Will the Land of Gandhi Become a Conventional Great Power? Asian Survey, 50(6), 1162-1183.

Layne, C. (1993). The Unipolar Illusion: Why New Great Powers Will Rise. International Security, 17(4), 5-51.

Layne, C. (2012). This Time It's Real: The End of Unipolarity and the Pax Americana. International Studies Quarterly, 56, 203-213.

Lee, M. (2006). The 21st Century Scramble for Africa. Journal of Contemporary African Studies, 24(3), 303-330.

LeoGrande, W. (1998). From Havana to Miami: US Cuba Policy as a Two-Level Game. Journal of Interamerican Studies and World Affairs, 40(1), 67-86.

Macfarlane, S. (2006). The ' $R$ ' in BRICs: Is Russia an Emerging Power? International Affairs, 82(1), 41-57.

Makwerere, D., \& Chipaike, R. (2012). China and the United States of America in Africa: A New Scramble or a New Cold War? International Journal of Humanities and Social Science, 2(17), 311-319.

Mohan, R. (2006) India and the Balance of Power. Foreign Affairs, 85, 17-32.

Nau, H. (2010). Obama's Foreign Policy, The Swing Away from Bush: How Far to Go? Policy Review, 160: 27-47.

NNIA, I (2013). US Economic Policy towards Nigeria: Implications, Pros \& Cons. Journal of Law, Policy and Globalization, 16(30), 30-35.

Nye, J. (2002). The Information Revolution and American Soft Power. Asia-Pacific Review, 9 (1), 60-76.

Nye, J. (2004). The Decline of America's Soft Power: Why Washington Should Worry. Foreign Affairs, 83(16), 16-20.

Nye, J. (2008). Recovering American Leadership, Survival: Global Politics and Strategy, 50(1), $55-68$. 
Nye, J. (2011). Understanding 21st Century Power Shifts. The European Financial Review.

Nye, J (2012). The Twenty-First Century will not be a Post-American World. International Studies Quarterly, 56, 215-217.

Paradise, J. (2009). China and International Harmony: The Role of Confucius Institutes in Bolstering Beijing's Soft Power. Asian Survey, 49(4), 647-669.

Pant, H. (2013). The BRICS Fallacy. The Washington Quarterly, 36(3), 91-105.

Pape, R. (2005). Soft Balancing Against the United States. International Security: 30(1), 7-45.

Paul, T (2005). Soft Balancing in the Age of US Primacy. International Security, 30(1), 46-71.

Posen, B. (2003). Command of the Commons: The Military Foundation of US Hegemony. International Security, 28(1), 5-46.

Purushothaman, U. (2010). Shifting Perceptions of Power: Soft Power and India's Foreign Policy. Journal of Peace Studies, 17(2\&3).

Ruggie, J. (1992). Multilateralism: The Anatomy of an Institution. International Organization, 46(3), 561-598.

Ruggie, J. (1994). Third Try at World Order? America and Multilateralism after the Cold War. Political Science Quarterly, 109(4), 553-570.

Sakwa, R. (2008). New Cold War' or twenty years' crisis? Russia and International Politics. International Affairs, 84(2) 241-267.

Schroeder, P. (1992). Did the Vienna Settlement Rest on a Balance of Power? The American Historical Review, 97(3), 683-706.

Scott, D. (2007). Strategic Imperatives of India as an Emerging Player in Pacific Asia. International Studies, 44(2), 123-140.

Serfaty, S. (2011). Moving into a Post-Western World. The Washington Quarterly 34(2), 7-23.

Slaughter, A. (2009). America's Edge: Power in the Networked Century. Foreign Affairs, 88(1), 94-113. 
Smith, K (2003). The European Union: A Distinctive Actor in International Relations.The Brown Journal of World Affairs, 9(2), 103-113.

Smith, K. (2013). Can the European Union be a Pole in a Multipolar World? The International Spectator: Italian Journal of International Affairs, 48(2), 114-126.

Smith, S. (2002). The End of the Unipolar Moment? September 11 and the Future of World Order. International Relations, 16 (2), 171-183.

Soares De Lima, M., \& Hirst, M. (2006). Brazil as an Intermediate State and Regional Power: Action, Choice and Responsibilities. International Affairs, 82(1), 21-40.

Sotero, P., \& Armijo, L. (2007). Brazil: To be or Not to Be a BRIC. Asian Perspective, 31(4), 43-70.

Srinivasan, T. (2006). China, India and the World Economy. Economic and Political Weekly, 41 (34), 3716-3727.

Starrs, S. (2013). American Economic Power Hasn't Declined-It Globalized! Summoning the Data and Taking Globalization Seriously. International Studies Quarterly, 57(4), 817-830.

Sweeny, K., \& Fritz, P. (2004). Jumping on the Bandwagon: An Interest-Based Explanation for Great Power Alliances. The Journal of Politics, 66(2), 428-499.

Tsygankov, A. (2006). If not By Tanks, Then By Banks? The Role of Soft Power in Putin's Foreign Policy. Europe-Asia Studies, 58(7), 1079-1099.

Tull, D. (2006). China's Engagement in Africa: Scope, Significance and Consequences. Journal of Modern African Studies, 44(3), 459-479.

Turner, S. (2009). Russia, China and a Multipolar World Order: The Danger in the Undefined. Asian Perspective, 33(1), 159-184.

Vandenbroucke, L. (1984). Anatomy of a Failure: The Decision to Land at the Bay of Pigs. Political Science Quarterly, 99(3), 471-491.

Wade, R. (2003). The Invisible Hand of the American Empire. Ethics and International Affairs $17(2), 77-88$

Walt, S. (2009). Alliances in a Unipolar World. World Politics, 1, 86-120. 
Wang, Y. (2008). Public Diplomacy and the Rise of Chinese Soft Power. The ANNALS of the American Academy of Political and Social Science, 616(1), 257-273

Wenping, H. (2010). Overturning the Wall: Building China's Soft Power in Africa. China Security, 6(1), 63-69.

Wohlforth, W. (1999). The Stability of a Unipolar World. International Security, 24(1), 5-41.

Wohlforth, W. (2002). Transatlantic Relations in a Unipolar World. Geneva Centre for Security Policy Occasional Papers, Series 41.

Wohlforth, W., Little, R., Kaufman, S., Kang, D., Jones, C., Hui, V., Eckstein, A., Deudney, D., \& Brenner, W. (2007). Testing Balance of Power Theory in World History. European Journal of International Relations, 13, 155.

Xinbo, W. (2010). Understanding the Geopolitical Implications of the Global Financial Crisis. The Washington Quaterly, 33(4), 155-163.

Zielonka, J. (2008). Europe as a Global Actor: Empire by Example? International Affairs, 84(3), 471-484.

Zhao, S. (2010). The China Model: Can it replace the Western Model of Modernization? Journal of Contemporary China, 19(65), 419-436.

\section{Working/Report/Monograph/Policy and Conference Papers}

Abisellan, E. (2012). Centcom's China Challenge: Anti-Access and Area Denial in the Middle East. Brookings: Foreign Policy.

Amr, H. (2004). The Need to Communicate: How to Improve U.S Public Diplomacy with the Islamic World. The Saban Centre for Middle East Policy at the Brookings Institution.

Blarel, N. (2012). India: the next superpower?: India's soft power: from potential to reality? IDEAS reports - special reports LSE IDEAS. London: London School of Economics and Political Science.

Bouchard, C., \& Peterson, J. (2011). Conceptualizing Multilateralism: Can We All Just Get Along? Mercury E-Paper 1. http://mercury.uni-koeln.de/fileadmin/user_upload/Epaper_no1_r2010.pdf

Brands, H. (2010). Dilemmas of Brazilian Grand Strategy. Strategic Studies Institute Monograph. 
Chen, J. (2011). The Emergence of China in the Middle East. Washington D.C: Institute for National Strategic Studies.

Congressional Research Service (CRS) (2008). China's Foreign Policy and 'Soft Power' in South America, Asia, and Africa. Library of Congress.

Ćwiek-Karpowicz, J. (2012). Limits to Russian Soft Power in the Post-Soviet Area. DGA Panalyse 8. https://dgap.org/en/article/getFullPDF/21791 (Accessed 8 June, 2014).

Edelman, E.S (2010). Understanding America's Contested Primacy. Washington D.C: Center for Strategic and Budgetary Assessments.

Ernst \& Young Emerging Market Centre (2012). Rapid-Growth Markets Soft Power Index. http://emergingmarkets.ey.com/wp-content/uploads/downloads/2012/05/TBF-606Emerging-markets-soft-power-index-2012_LR.pdf (Accessed 21 August, 2014).

Filimonov, G. (2010). Russia's Soft Power Potential. Russia in Global Affairs. Russian Soft Power Tools in the CIS. http://eng.globalaffairs.ru/number/Russias-Soft-Power-Potential$\underline{15086}$ (Accessed 8 June, 2014).

Freedom House (2013). Freedom in the World 2013: Democratic Breakthroughs in the Balance. https://www.freedomhouse.org/sites/default/files/FIW\%202013\%20Booklet.pdf

Grevi, G. (2009). The Interpolar World: A New Scenario. Paris: European Institute for Security Studies: Occasional paper 79.

Harrison, A., \& Sepulveda, C. (2011). Learning From Developing Country Experience: Growth and Economic Thought Before and after the 2008-09 crisis. The World Bank Policy Research Working Paper 5752. New Hampshire: World Bank

Horta, L. (2009). China in Africa: Soft Power, Hard Results. Yale Global Online. http://yaleglobal.yale.edu/content/china\%E2\%80\%99s-soft-power-africa-could-have-hardresults

ISS. (2010). Global Governance 2025: At a Critical Juncture. Paris: EU Institute for Security Studies.

Jokela, J. (2011). The G-20: A Pathway to Effective Multilateralism? Paris: EU Institute for Security Studies. 
Kim, Y. (2013). Chinese-Led Sezs in Africa: Are They a Driving Force of China's Soft Power? Stellenbosch: Centre for Chinese Studies.

Laidi, Z. (2011). The BRICS against the West? CERI Strategy Papers 1. http://www.cerisciences.po.org

Lazarou, E. et al. (2010). The Evolving 'Doctrine' of Multilateralism in the 21st Century. Mercury E-paper 3, 1-34.

Meyer, M. (2003). Arab Perception Toward US Foreign Policy: Why Perceptions Matter and What Can Be Done to Improve America's Image in the Arab World. Occassional Paper 48. Washington D.C: Institute for National Security Studies.

Moffett, M. (2008). Brazil Joins Front Rank of New Economic Powers. The Wall Street Journal Online. http://www.wsj.com/articles/SB121063846832986909

Morrison, W. (2014). China's Economic Rise: History, Trends, Challenges, and Implications for the United States. Washington D.C: Congressional Research Service.

National Intelligence Council (2008). Global Trends 2025: A Transformed World. NIC 003. http://www.aicpa.org/research/cpahorizons2025/globalforces/downloadabledocuments/globaltren ds.pdf

O’Neill, J. (2001). Building Better Global Economic BRICs. Global Economics Paper No. 66. New York: Goldman Sachs \& Co. http://www.goldmansachs.com/our-thinking/archive/archivepdfs/build-better-brics.pdf

Opendoors (2013). Fast Facts: International Students in the US. Opendoors. New York: Institute of International Education.

Pew Survey (2012). Global Opinion of Obama Slips, International Policies Faulted. Washington D.C: Pew Research Centre.

Pew Survey (2013). America's Global Image Remains More Positive than China's: But Many See China Becoming World's Leading Power. Washington D.C: Pew Research Centre.

Popescu, N. (2006). Russia's Soft Power Ambitions CEPS Policy Briefs issue, 112, 1-3. London: Centre for European Studies.

Renard, T. (2009). A BRIC in the World: Emerging Powers, Europe, and the Coming Order. Brussels: Egmont-Royal Institute for International Relations. 
Ramo, J. (2004). The Beijing Consensus. London: The Foreign Policy Centre.

Roubini, N. (2009). The Chinese Proposal for a New Global Super Currency. RGE Monitor. http://www.economonitor.com/nouriel/2009/06/26/the-chinese-proposal-for-a-new-global-supercurrency/

Shamsi, Z. (2012). Indian Air Force Modernization Plan of 2020: Challenges for Regional Air Forces. Canberra: Australian Defence College.

Sharp, J. (2005). The Middle East Partnership Initiative: An Overview. Washington D.C: Congressional Research Service, RS21457.

Shim, D., \& Flamm, P. (2012). Rising South Korea: A Minor Player or a Regional Power? GIGA Working Papers 200. Hamburg: German Institute of Global and Area Studies

Skak, M. (2011) The BRIC Powers as Actors in World Affairs. Soft Balancing or...? IPSA-ECPR Joint Conference hosted by the Brazilian Political Science Association at the University of Sao Paulo, 16-19 February, 2011: Whatever happened to North-South?

Stoner-Weiss, K., \& McFaul, M. (2009). Domestic and International Influences on the Collapse of the Soviet Union (1991) and Russia's Initial Transition to Democracy (1993). Stanford: Centre on Democracy, Development and the Rule of Law.

Toje, A. (2010). The Tragedy of Small Powers: The European Union under Multipolarity” The Norwegian Atlantic Committee.

Wagner, C. (2012). Emerging Powers in Regional Architecture. Asia Division German Institute for International and Security Affairs Working Paper FG 7. Berlin: German Institute for International and Security Affairs.

Wezeman, P. (2011). South African Arms Supplies to Sub-Saharan Africa. Stockholm: Stockholm International Peace Reaserch Institute.

Williams, B. (2013). African Growth and Opportunity Act (AGOA): Background and Reauthorization. Washington D.C: Congressional Research Service.

World Bank (2013). World Development Indicators Database.

Yoshihara, T., \& Holmes, J. (2007). China's Energy-Driven Soft Power. Elsevier Limited on behalf of Foreign Policy Research Institute. http://ac.els-cdn.com/S0030438707001196/1- 
s2.0-S0030438707001196-main.pdf?_tid=444be08a-b825-11e4-93d0-

00000aacb35e\&acdnat=1424343272_35855621b1cfab6207df039107c44827

\section{Newspapers}

Plessis, C. (2013, 22 March.). SA Still Snubbing Africom. City Press, http://www.citypress.co.za/politics/sa-still-snubbing-africom/

Withnall , A. (2014, 27 February). Rio Carnival 2014 in Numbers: Brazil Kicks off the Greatest Party on Earth Tomorrow- But Where Will the Samba Parades Take You? The Independent. http://www.independent.co.uk/news/world/americas/rio-carnival-2014-innumbers-brazil-kicks-off-the-greatest-party-on-earth-tomorrow--but-where-will-thesamba-parades-take-you-9157909.html

\section{Internet Sources}

BBC (2014, January 6). The Mint countries: Next economic giants? http://www.bbc.com/news/magazine-25548060

Bordachev, T. (2009). Multipolarity, anarchy and security. In I.Krastev, M. Leonard, \& A. Wilson (Eds.), What Does Russia Think? European Council on Foreign Relations. www.ecfr.eu

Copeland, F. (2013). The Boko Haram Insurgency in Nigeria. https://www.cimicweb.org/cmo/medbasin/Holder/Documents/r028\%20CFC\%20Monthly\% 20Thematic\%20Report\%20(21-FEB-13).pdf

Forbes (2014a). The 2014 Millionaire Race: Goodbye BRICs, Hello MINTs. http://www.forbes.com/sites/doliaestevez/2014/01/27/the-2014-millionaire-race-goodbyebrics-hello-mints/

Forbes (2014b). After The BRICS Are The MINTs, But Can You Make Any Money From Them? http://www.forbes.com/sites/chriswright/2014/01/06/after-the-brics-themints-catchy-acronym-but-can-you-make-any-money-from-it/

Levin, G. (2011). From Isolationism to Internationalism: The Foreign Policy Shift in Republican Presidential Politics, 1940-1968. http://www.jhubc.it?admissionsblogdocuments/paper\%20isolation\%201.2.2012.pdf 
Shabbir Deen, E. (2013). AFRICOM: Protecting US Interests Disguised as Military Partnerships. http://studies.aljazeera.net/en/reports/2013/05/2013521122644377724.htm

Summerfield, R. (2014, March). MINT Countries to Be Next Economic Giants? Financial Worldwide magazine. $\mathrm{http} / /$ www.financierworldwide.com/article.php?id=11668

Stockholm International Peace Research Institute Database. http://www.sipri.org/reserch/armaments/milex/Top\%2015\%20table\%202012.pdf

Thakur, R. (2012). The United Nations in Global Governance: Rebalancing organized Multilateralism for Current and future Challenges. http://www.un.org/en/ga/president/65/initiatives/GlobalGovernance/ThakurGAThematicD ebateonUNinGG.pdf

The Independent (2013, December 15). The Castropedia: Fidel's Cuba in Facts and Figures. http://www.independent.co.uk/news/world/americas/the-castropedia-fidels-cuba-in-factsand-figures-432478.html

The Twitaholic.com Top 100 Twitterholics Based on Followers. http:/twitaholic.com/top100/followers/

United States' President's Emergency Plan for Aids Relief. Partnership to fight HIV/AIDS in Nigeria. http://www.pepfar.gov/documents/organization/199599.pdf

United States' President's Emergency Plan for AIDS Relief. Partnership to Fight HIV/AIDS in South Africa. A Decade of Impact: 2003-2013. http://photos.state.gov/libraries/southafrica/917455/nevhulaudzirk/PEPFAR-SA-Fact2013.pdf 


\section{Appendix}

\section{INTERVIEW GUIDE}

\section{SCHOLARS}

1 How would you characterize the position of the United States in contemporary global politics? Is it a hegemonic or a declining power?

2) How should the United States relate with China?

3) In what direction is the power shift in international politics?

4) Is the global impact of the United States born economic crisis a reflection of the United States dominance in the global economy?

5) What are the sources of the United States and China soft power?

6) To what extent do the United States and China wield soft power in Africa and the Middle East?

7) Does Africa/Middle East view the Chinese model as an alternative to Western liberalism particularly after the global financial and economic crisis?

8) How would you describe the structure of power in contemporary international politics

\section{BUREAUCRATS}

1) What has been the volume of the United States/China foreign aid in Africa/Middle East in the past five years? What does the United States/China expect in return for its foreign aid contribution? How does the United States/China handle unmet expectations?

2) How many students from Africa/Middle East have been enrolled in the United States/China universities in the past five years? What attracts African/Middle Eastern students to the United States/China

3) To what extent are American/Chinese MNC's visible in Africa/Middle East?

4) Do Africa and the Middle East feel threatened by the presence of the United States/ China in their countries

5) Following the United States born financial crisis, does Africa/Middle East view the Chinese model as an alternative to Western liberalism 